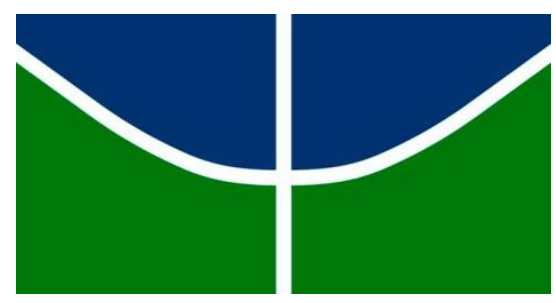

Universidade de Brasília

Instituto de Geociências

Programa de Pós Graduação em Geologia

Tese de Doutorado

\title{
PROCESSOS ACRESCIONÁRIOS NA PORÇÃO \\ CENTRAL DE GONDWANA: EXEMPLOS DE TERRENOS \\ ALTO MOXOTÓ E ALTO PAJEÚ DA PROVÍNCIA \\ BORBOREMA, NE DO BRASIL
}

Lauro Cézar Montefalco de Lira Santos

TESE DE DOUTORADO No 134

Orientador: Prof. Dr. Elton Luiz Dantas

BRASÍLIA, 2017 
Dedicado à Ayanne Melo, Edilton Santos, Maria Liége e Maria Laura, por me ensinar diferentes significados do amor.

"A ciência nunca resolve um problema sem criar pelo menos outros dez"

George B. Shaw. 


\section{Agradecimentos}

Depois de repetidas leituras, o prazo e exaustão me fizeram entregar (com certa relutância) o presente documento. Sua elaboração não foi fácil, deixando alguns (muitos) traumas e aprendizados. Não teria conseguido sem a presença de Deus. Tenho certeza que mesmo nos momentos que acreditei não ser capaz, ele acreditou. Agradeço a minha família, em especial aos meus pais por todo amor, compreensão e apoio. Minha esposa é igualmente agradecida, principalmente por sua paciência e companheirismo.

Agradeço aos professores e funcionários do Instituto de Geociências da UnB, em especial ao Prof. Elton Dantas pelas orientações prestadas, bem como o pessoal do Laboratório de Geocronologia. São também merecedores dos meus agradecimentos os colegas professores e funcionários da Unidade Acadêmica de Mineração e Geologia da Universidade Federal de Campina Grande, em especial ao Coordenador Administrativo José Avelino Freire, que nunca hesitou em flexibilizar minhas atividades para que eu pudesse desenvolver a presente tese. Ao longo desses 4 anos, não faltaram pessoas para desencorajar e criticar por criticar meu trabalho e idéias, entretanto, procuro guardar as palavras de verdadeiros motivadores, tais como: Reinhardt Fuck, Benjamin Bley, Carlos Archanjo, Sandra Barreto, Roberta Vidotti, Massimo Mateinni e Valmir Souza. Agradeço ainda, aos colegas Haroldo Lima, Davi Saldanha, Luiz Passos, Salomão Calegari e Diego Timoteo. Dedico também agradecimento especial à banca examinadora. Agradeço ainda aos geólogos Geysson Lages, Roberta Brasilino e Joseneusa Brilhante pela colaboração científica.

Additional thanks are to Prof. Peter A. Cawood (St. Andrews University). His patience, kindness and understanding are truly inspiring. My dear advisor/friend, your support was priceless, wish you all the best! 


\section{SUMÁRIO}

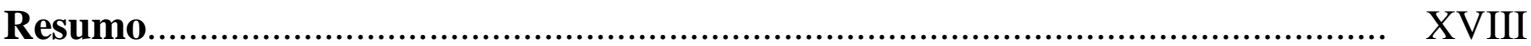

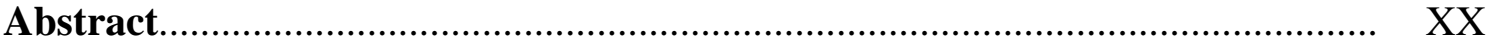

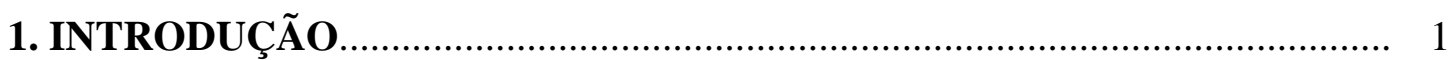

1.1. Apresentação e justificativa do tema proposto.................................... 1

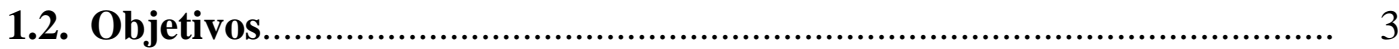

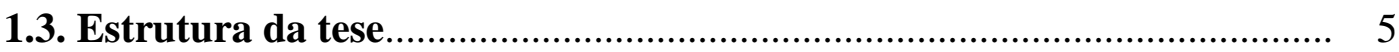

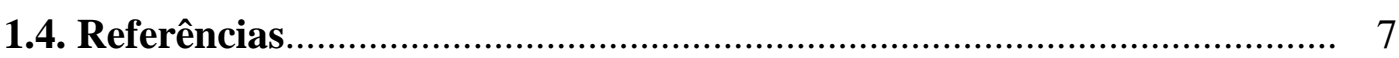

2. CONTEXTO GEOLÓGICO............................................................... 10

2.1. Província Borborema.......................................................................... 10

2.1.1. Subprovíncia Transversal (SPT) ........................................................... 13

2.1.1.1 Terreno Alto Moxotó (TAM) ................................................................... 14

2.1.1.2 Terreno Alto Pajeú (TAP) .................................................................... 16

2.2. Breve descrição da geologia da região de Airi (PE) .............................. 17

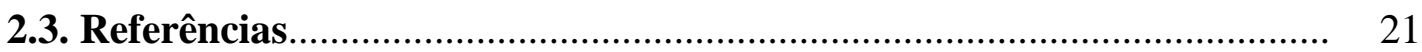

3. ARTIGo CIENTÍfICO 1: TWO-STAGE TERRANE ASSEMBLY IN THE CENTRAL PORTION OF THE BORBOREMA PROVINCE, NE BRAZIL: INSIGHTS FROM STRUCTURAL GEOLOGY AND

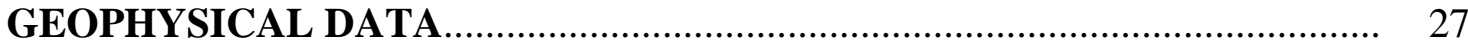

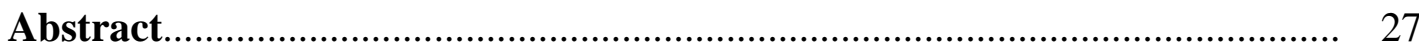

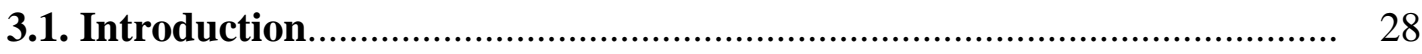

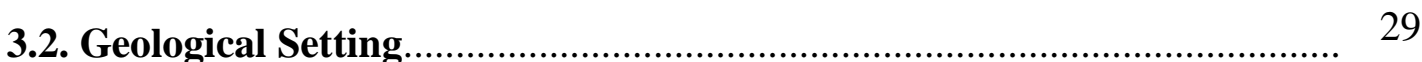

3.2.1. Borborema Province.......................................................................... 29

3.2.1.1. Alto Pajeú Terrane ............................................................................. $\quad 30$

3.2.1.2. Alto Moxotó Terrane ................................................................................. 31

3.2.1.3. Pernambuco-Alagoas Terrane ............................................................ 32

3.2.1.4. Nature of the proposed Terrane boundaries........................................... 33

3.3. Geophysical dataset.......................................................................... 37

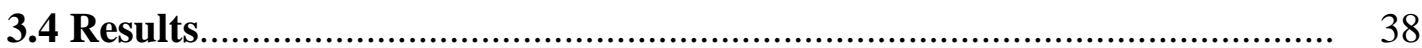

3.4.1. Gamma ray spectrometric data.......................................................... 38

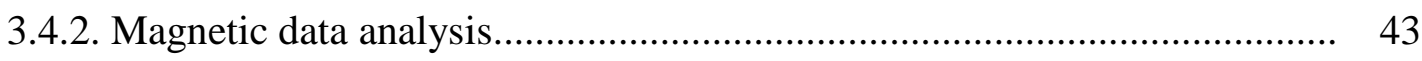

3.4.2.1. Euler Deconvolution ............................................................................ 49

3.4.3. Structural Analysis............................................................................ $\quad 50$ 
3.4.3.1. Ductile deformation stages................................................................... 53

3.4.3.2. Brittle deformation.............................................................................. 55

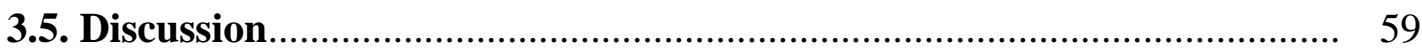

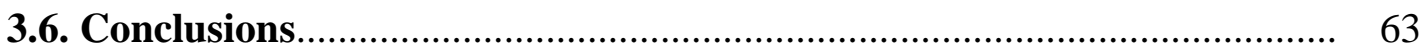

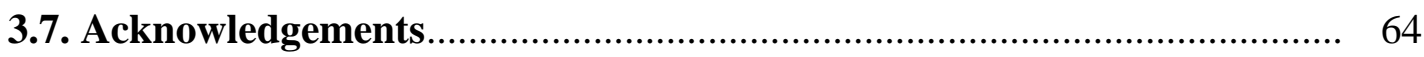

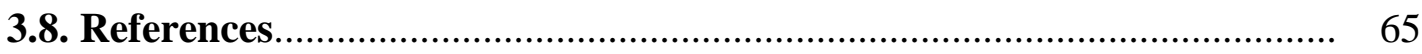

4. ARTIGO CIENTÍFICO 2: NEOARCHEAN CRUSTAL GROWTH AND PALEOPROTEROZOIC REWORKING ON THE BORBOREMA PROVINCE, NE BRAZIL: INSIGHTS FROM GEOCHEMICAL AND ISOTOPIC DATA OF TTG AND METAGRANITIC ROCKS OF THE ALTO MOXOTÓ TERRANE.................................................................. 74

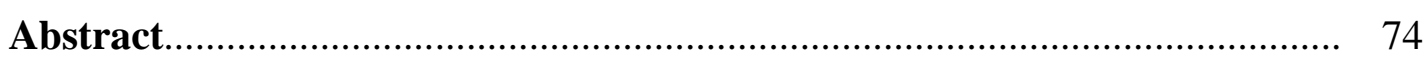

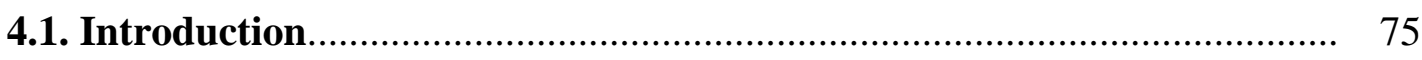

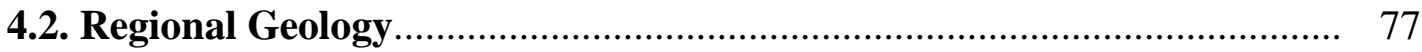

4.2.1 Borborema Province............................................................................... 77

4.2.1.1. Transversal sub province .................................................................... 78

4.2.1.1.1. The Alto Moxotó Terrane .................................................................... 78

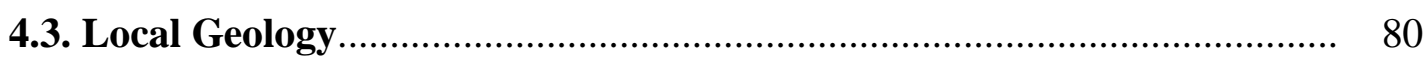

4.3.1. Riacho das Lajes Suite ..................................................................... 81

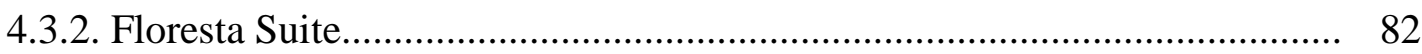

4.4. Analytical Procedures...................................................................... 87

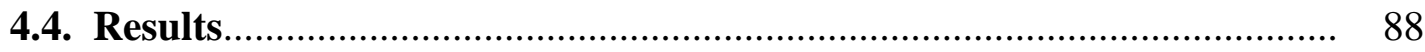

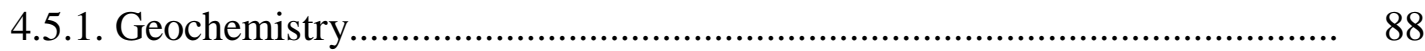

4.5.1.1. Riacho das Lajes Suite ......................................................................... 88

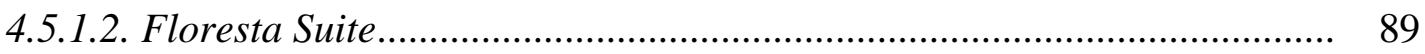

4.5.2. U-Pb Geochronology....................................................................... 91

4.5.2.1. Riacho das Lajes Suite ........................................................................... 92

4.5.2.2. Floresta Suite .................................................................................. 94

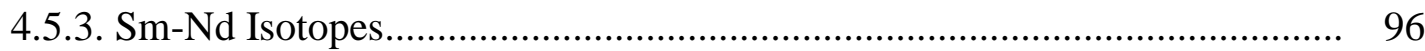

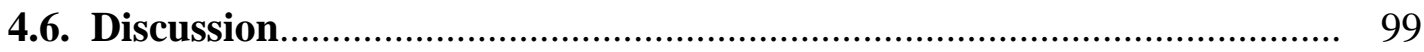

4.6.1. Magma sources and tectonic setting.................................................... 99

4.6.1.1. Riacho das Lajes Suite ..................................................................... 99

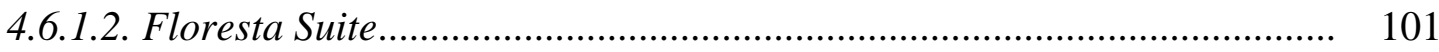


4.6.2. Neoarchean crustal growth, Paleoproterozoic reworking and regional correlations

4.6.3. Tectonic evolution of the Alto Moxotó Terrane and implications for supercontinent reconstructions.

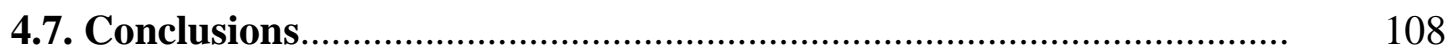

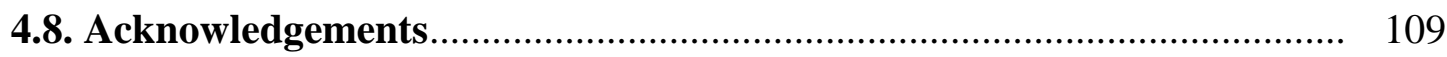

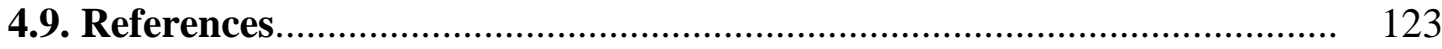

5. ARTIGO CIENTÍFICO 3: STATHERIAN TO CALYMINIAN

MAGMATISM IN THE ALTO MOXOTÓ TERRANE, BORBOREMA PROVINCE, NE BRAZIL: IMPLICATIONS FOR WITHIN PLATE AND COLLISION TECTONICS IN WEST GONDWANA .................................. 136

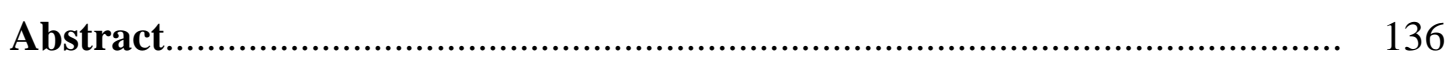

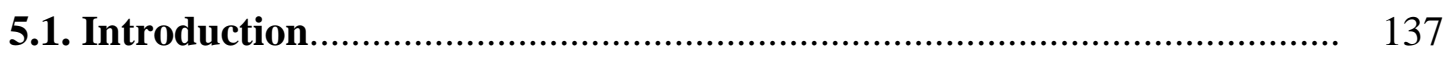

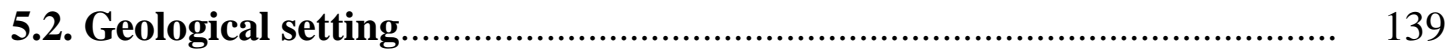

5.2.1. Borborema Province................................................................................ 139

5.2.1.1. The Alto Moxotó Terrane ........................................................................ 141

5.2.1.2. Field aspects and petrography of the studied suites.............................. 142

5.3. Analytical procedures......................................................................... 147

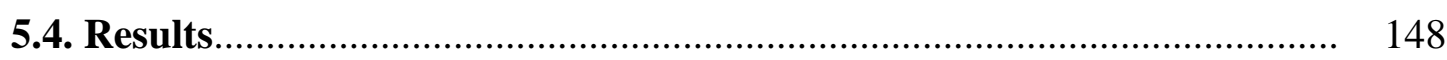

5.4.1. LA-MC-ICP-MS U-Pb zircon dating................................................... 148

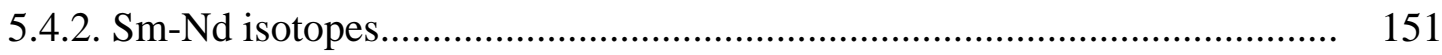

5.4.3. Whole-rock geochemistry..................................................................... 152

5.4.3.1. Riacho do Navio Suite ......................................................................... 152

5.4.3.2. Coloete Orthogneisses....................................................................... 152

5.4.3.3. Carnoió Suite .................................................................................... 153

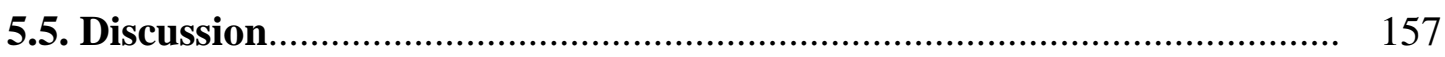

5.5.1. Age, sources and tectonic setting..................................................... 157

5.5.2. Tectonic implications and regional correlations........................................ 160

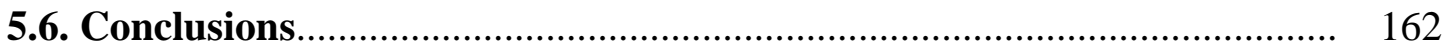

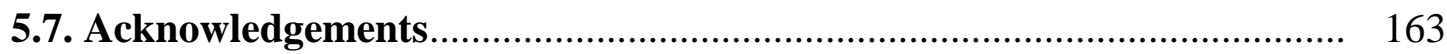

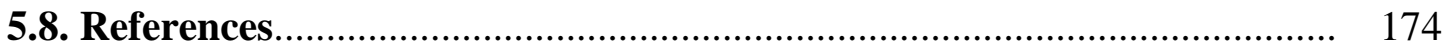


6. ARTIGO CIENTÍFICO 4: Sm-Nd ISOTOPE MAPPING OF TERRANES

IN THE TRANSVERSAL SUBPROVINCE OF THE BORBOREMA 182

PROVINCE, NE BRAZIL: IMPLICATIONS FOR ACCRETION TECTONICS IN WEST GONDWANA.

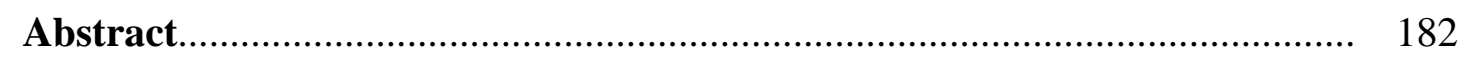

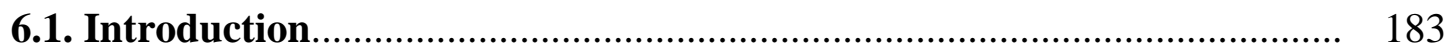

6.2. Geological setting.............................................................................. 184

6.3. Rock sampling and analytical procedures............................................ 190

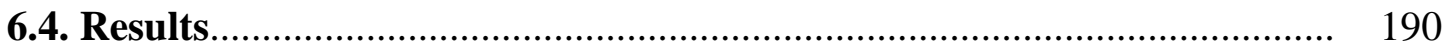

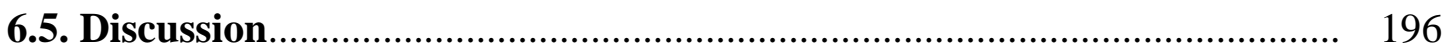

6.5.1. Nature and source ages................................................................... 196

6.5.2. Tectonic implications.......................................................................... 197

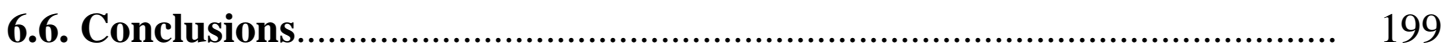

6.7. Acknowledgements............................................................................ 200

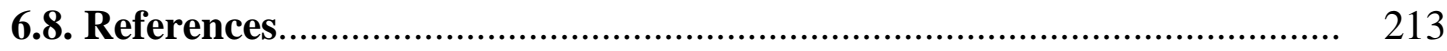

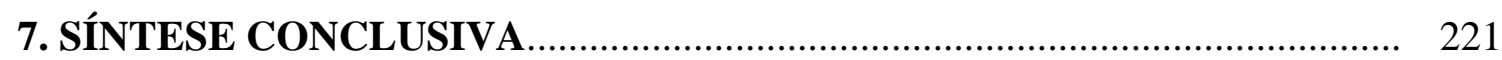

8. ANEXO 1 - ARTIGO CIENTÍfICO 5: ANÁLISE TECTÔNICA DE TERRENOS: METODOLOGIA, APLICAÇÃO EM CINTURÕES OROGÊNICOS E EXEMPLO DAS PROVÍNCIAS TOCANTINS E

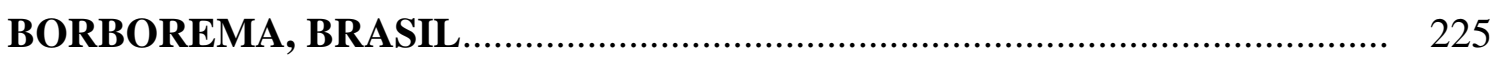

Resumo

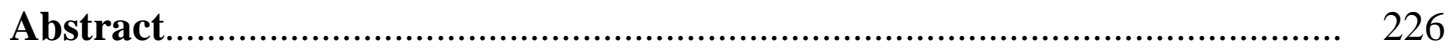

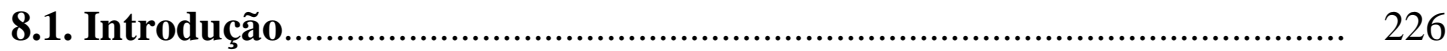

8.2. Histórico do modelo e conceituação......................................................... 227

8.2.1. Terrenos estratigráficos...................................................................... 228

8.2.2. Terrenos metamórficos...................................................................... 228

8.2.3. Terrenos fragmentados.................................................................. 228

8.3. Conceitos complementares................................................................... 229

8.4. Mecanismos de colagem e fragmentação de terrenos............................... 229

8.4.1. Construção (Amálgamação e Acreção) ..................................................... 230

8.4.2. Destruição ou modificação continental (Rifteamento e Dispersão) 231

8.5. Platôs oceânicos e terrenos........................................................................ 233 


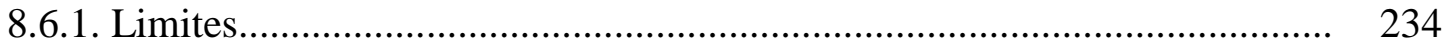

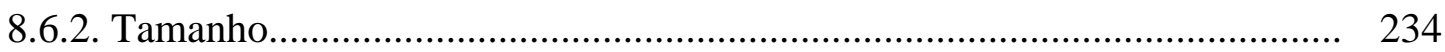

8.7. Deslocamentos e trajetórias................................................................... 234

8.8. Evidências de formação de terrenos........................................................ 235

8.9. Técnicas utilizadas na análise tectônica de terrenos............................... 238

8.10. Registro de tectônica acrescionária em províncias Neoproterozoicas 243 brasileiras.

8.10.1. Província Tocantins (Brasil Central) .......................................................... 243

8.10.2. Província Borborema (NE do Brasil) ........................................................ 245

8.11. Considerações finais.......................................................................... 247

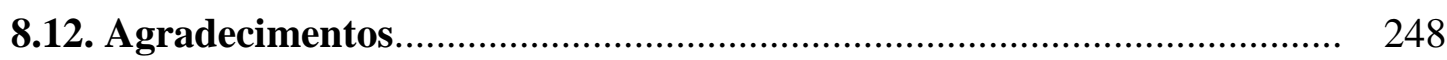

8.13. Referências.......................................................................................... 249

\section{LISTA DE FIGURAS}

Figura 1.1 - Localização da Província Borborema no contexto do Gondwana Ocidental, em sua posição atual. Maiores blocos cratônicos: $\mathrm{CA}=$ Cráton Amazônico; SF = Cráton do São Francisco; RP = Cráton Rio de La Plata; COA = Cráton do Oeste-Africano; $\mathrm{CC}=$ Cráton do Congo; $\mathrm{CK}=$ Cráton Kalahari; $\mathrm{MCS}=$ Meta Crátón do Saara.

Figura 1.2 - Localização geográfica da área de trabalho (retângulo em destaque) e as principais rodovias de acesso a partir de Recife, Pernambuco.

Figura 2.1 - Subdivisão geotectônica da Província Borborema com e idade dos diversos segmentos crustais. Modificado de vários autores (eg. Santos, 1996; Brito Neves et al., 2000; Van Schmus et al., 2008). Siglas das subprovíncias: SMC = Médio Coreaú, $\mathrm{SCC}=$ Ceará Central; SRN = Rio Grande do Norte; STR = Transversal; $\mathrm{SME}=$ Meridional..

Figura 2.2 - Mapa de distribuição dos terrenos da Subprovíncia Transversal compilado de vários autores com a área de estudo delimitada pelo retângulo azul marinho. 
Figura 2.3 - Mapa geológico da região de Airí. Suítes graníticas Brasilianas: I = Serra do Arapuá ; II = Riacho do Icó, III = Quixaba, IV = Fortuna

Figure 3.1 - a) Pre-drift reconstruction of Northeast South America and West Africa in West Gondwana context with the main structural provinces and lineaments on its current position. SJCT $=$ São José do Caianho Terrane, PABT = Piancó Alto-Brigída Terrane, APT = Alto Pajeú Terrane, AMT = Alto Moxotó Terrane, $\mathrm{RCT}=$ Rio Capibaribe Terrane, $\mathrm{TBL}=$ Transbrasiliano Lineament, KL Khandi Lineament, $\mathrm{PaL}=$ Patos Lineament, $\mathrm{GAL}=$ Garoua Lineament, $\mathrm{PeL}=$ Pernambuco Lineament, $\mathrm{AL}=$ Adamoua Lineament.

Figure 3.2 - Geological map of the study area. Ediacaran granitic suites: I = Serra do Arapuá, II = Riacho do Icó, III - Quixaba, IV = Fortuna. Terranes: APT = Alto Pajeú, $\mathrm{AMT}=$ Alto Moxotó, PEALT = Pernambuco Alagoas. JB = Jatobá Basin.... 36

Figure 3.3 - Covered area by the Pernambuco-Paraíba and Paraíba-Rio Grande do Norte projects from Brazilian Geological Survey in NE Brazil, with a satellite image of the study area

Figure 3.4 - Gamma-ray spectrometric products of the study area: a) Ternary RGB composition map; b) map of interpreted radiometric domains. Such domains are defined by contrasting signatures on the total count map. The thick yellow dashed line represent the terrane boundaries. The same is displayed to Figures 3.5 to 3.7... 41

Figure 3.5 - Gamma-ray spectrometric maps as well as the main proposed terrane boundaries: a) Total count $(\mu \mathrm{R} / \mathrm{h})$; b) $\mathrm{Th} / \mathrm{K}$ ratio. c) and d) corresponds to structural interpretations of a) and b) respectively. The thick red lines represent the major radiometric lineaments, whereas the blue lines correspond to secondary lineaments. The thick yellow dashed line represent the terrane boundaries. The same is displayed to Figures 3.6 to 3.8 .

Figure 3.6 - Magnetic maps: a) Magnetic anomaly and b) Total Gradient Amplitude (TGA). c) and d) corresponds to structural interpretations of a) and b) 
respectively

Figure 3.7 - Magnetic products: a) First vertical derivate and b) Tilt derivate maps. Note the splay termination of shear zones between the studied terranes as well as sigmoid shapes imposed by the intercalation of magnetic structures. c) and d) corresponds to structural interpretations of a) and b) respectively.

Figure 3.8 - Interpreted magnetic domains and main magnetic lineaments of the study area. The different magnetic domains was interpreted based on magnetic intensity, relief and orientation of first order and second order lineaments

Figure 3.9 - 3D Euler deconvolution of the study area using a structural index of 1. PeL = Pernambuco Lineament, SJSZ = Serra de Jabitacá Shear zone

Figure 3.10 - Integrated geophysical and geological data of the main structures of the study area. PSSZ = Poço do Salgueiro shear zone; CSZ = Carqueja shear zone; AISZ = Afogados da Ingazeira Shear zone; SPAZ = Santa Paula Shear Zone; LDZ = Lagoa do Defunto Shear Zone; SPZ = São Pedro Shear Zone; BFSZ = Barra da Forquilha Shear Zone; RQ = Riacho Quixaba Shear Zone; SJSZ = Serra de Jabitacá Shear Zone; FSZ = Floresta Shear Zone; AISZ = AiríShear Zone; RJSZ = Riacho Jacaré Shear Zone; PeL = Pernambuco Lineament; PASZ = Poço da Areia Shear Zone; RBSZ = Riacho do Buraco Shear Zone; RMSZ = Riacho da Maravilha Shear Zone; IF = Ibimirim Fault.

Figure 3.11 - Structural map of the study area with schematic geological sections and synthetic contour plots stereograms (lower hemisphere Schmidt projections). Names of structures are the same as in Figure 6.10

Figure 3.12 - Structural markers related to $D_{n}$ and $D_{n+1}$ phases. a) Stromatic to folded migmatite of the ca. 2.6 Ga Riacho das Lajes Suite exhibiting relict $S_{n}$ foliation (intrafolial fold) in a metatexitic facies; b) strongly mobilized diatexite of the Riacho das Lajes Suite showing schollen structure associated with mafic facies; c) gently dipping $\mathrm{S}_{\mathrm{n}+1}$ foliation in tabular sheet of Tonian metagranitoid of 
the Alto Pajeú Terrane; d) High pitch $\mathrm{L}_{\mathrm{n}+1}$ mineral stretching lineation on finegrained Tonian (ca. $0.92 \mathrm{Ga}$ ) metagranitoid

Figura 3.13 - Structural markers related to $D_{n+2}$ phase $D_{n+1}$ phases. a) $F_{n+1}$ ptygmatic folds indicating distinct competency between leucocratic and mesocratic materials; b) $8 \% 360 \mathrm{Az}$ dipping $\mathrm{S}_{\mathrm{n}+1}$ mylonitic fabrics in a linear tectonite of the ca. $0.97 \mathrm{Ga}$ São Caetano Complex, with associated asymmetric porphyroclasts suggesting top-to-the-S thrust vergence; c) quartz ribbons with ondulose extinction in a recrystallized quartz matrix in protolylonitic rock; d) micafish developed in a mylonitic facies of the São Caetano Complex associated with the Serra de Jabitacá Shear Zone, exhibiting clockwise movement.

Figure 3.14 - Structural markers related to $D_{n+2}$ phase. a) Banded orthogneiss of the ca. 2.1 Ga Floresta Suite displaying deformed leuco- and mesocratic E-W bends; b) horizontal $L_{n+2}$ stretching mineral lineation associated to a vertical $S_{n+2}$ foliation plane of the Pernambuco Lineament; c) photomicrograph of granodioritic mylonite with mica fish arranged between C-type shear bands associated with the Pernambuco Lineament; d) oblique $\mathrm{L}_{\mathrm{n}+2}$ lineation in myloniticparagneiss of the ca. 2.01 Ga Sertânia Complex related to the Pernambuco Lineament.

Figure 3.15 - Structural markers related to a) $D_{n+3}$ Conjugated pair of fractures forming domino-like structures of deformation cross-cutting $\mathrm{S}_{\mathrm{n}+2}$ foliation planes in paragneiss of the ca. 0.97 Ga São Caetano Complex; b) Detail of fracture plane 59 showing neo-formed mineral aggregates of quartz, chlorite and sericite.

Figure 3.16 - Structural model for terrane collage between the studied terranes. Terranes - AMT - Alto Moxotó, APT = Alto Pajeú, RCT = Rio Capibaribe, PEALT $=$ Pernambuco Alagoas. Shear zones - RBSZ $=$ Riacho do Boi, PASZ = Poço da Areia, $\mathrm{PL}=$ Pernambuco Lineament, $\mathrm{ASZ}=$ Airí, FSZ $=$ Floresta, $\mathrm{SJSZ}=$ Serra de Jabitacá, BFSZ = Barra da Forquilha, AISZ = Afogados da Ingazeira. TB $=$ Terrane boundary.

Figure 4.1 - Geodynamic context of the Borborema Province in Pre-Drift 
reconstruction for West Africa and northeast South America, b) tectonic framework of the Borborema Province and c) Simplified geological map of the Transversal Sub province and its terranes with the study area highlighted.....

Figure 4.2 - Geological map of the Airi area with the location of the Riacho das Lajes and Floresta suites. PEL = Pernambuco Lineament, SJN = Serra de Jabitacá Nappe. The red circles of Floresta and Airí represents the main towns of the area... 80

Figure 4.3 - Field aspects of metaplutonic studied rocks. a) Discretely foliated metagranitoid (Riacho das Lajes suite); b) Biotite gneiss with well developed compositional bending (Riacho das Lajes suite); c) Stromatic metatexite with tonalitic protolith (Riacho das Lajes suite); d) Isotropic metagranitoid with granodioritic composition (Floresta suite); e) Isotropic metatonalite (Floresta Suite); e) Compositional banding of tonalitic to granodioritic orthogneiss (Floresta 84 Suite)

Figure 4.4 - Modal composition of studied samples from Riacho das Lajes and Floresta suites reported in the Q-A-P triangular diagram from Streckeisen (1976)... 85

Figure 4.5 - Photomicrographs of the studied rocks (a to e $=$ crossed nicols and $\mathrm{f}=$ parallel nicols). a) Hipidiomorphic granular texture in metatonalite (Riacho das Lajes Suite); b) Granoblastic texture exhibiting deformed qtz grains in metagranodiorite (Riacho das Lajes Suite); c) Elongated biotite quatrz within quartz-plagioclase aggregates in metagranodiorite (Riacho das Lajes Suite); d) and e) Hipidiomorphic granular textures in metatonalite and metadiorite respectively (Floresta Suite) with granoblastic texture, f) Greenish hornblende aggregates in metagranitic rock (Floresta Suite)

Figure 4.6 - Geochemical characteristics of the Riacho das Lajes and Floresta suites. a) Normative An-Ab-Or triangle (O’Connor, 1965); b) $\mathrm{SiO}_{2}$ vs. $\mathrm{Na}_{2} \mathrm{O}+$ $\mathrm{K}_{2} \mathrm{O}-\mathrm{CaO}$ diagram (Frost et al. 2001); c) $\mathrm{SiO} 2$ vs. FeOt/(FeOt $+\mathrm{MgO}$ ) diagram (Frost et al. 2001); d) $\mathrm{Al}_{2} \mathrm{O}_{3} /\left(\mathrm{Na}_{2} \mathrm{O}+\mathrm{K}_{2} \mathrm{O}\right)$ molar vs. $\mathrm{Al}_{2} \mathrm{O}_{3} / \mathrm{CaO}+\mathrm{Na}_{2} \mathrm{O}+\mathrm{K}_{2} \mathrm{O}$ ) molar diagram (Maniar and Picolli, 1989); e) Cationic Ca-Na-K diagram showing 
Figure 4.7 - a) Spider diagrams of trace elements abundances; b) REE abundances for rocks of the Riacho das Lajes Suite, 1995; c) Spider diagrams of trace elements abundances and b) REE abundances for rocks of the Floresta Suite. Spiderdiagrams were normalized by primitive mantle from Mcdonough and Sun, 1995 and REE normalized by Chondrite from Nakamura (1974). Black circles = Riacho das Lajes Suite, Red circles = Floresta Suite

Figure 4.8 - Selected cathodoluminescene images of analyzed zircons for $\mathrm{U}-\mathrm{Pb}$ geochronology.

Figure 4.9 - U-Pb zircon age of metatonalite from the Riacho das Lages Suite (Sample FL-56)

Figure 4.10 - U-Pb zircon age for a metagranodiorite of the Riacho das Lajes Suite (sample FL-105)......

Figure 4.11 - U-Pb Concordia diagram for a metadiorite of the Floresta suite (sample FL-65)

Figure 4.12 - U-Pb Concordia diagram for a metatonalite of the Floresta suite (sample FL-60)

Figure 4.13 - Distribution of obtained Nd data along the Riacho das Lajes and Floresta Suites. The white circles represent the location of selected samples for U$\mathrm{Pb}$ analysis. White circles represent the $\mathrm{U}-\mathrm{Pb}$ dated samples.

Figure 4.14 - Nd evolution diagram for the metaplutonic rocks of a) Riacho das Lajes and b) Floresta Suites 
Figure 4.15 - Plots for the Riacho das Lajes Suite: a) Sr/Y diagram with fields of Archean TTG and adakites and normal calc-alkaline rocks from Drummond and Defant (1990) and b) (La/Yb)n vs. (Yb) diagram. Fields of Archean TTG and post-Archean granitoids are from Martin (1986). Partial melting curves of eclogites, garnet amphibolites and amphibolites were calculated using the batch melting equation of Shaw (1970) and the partition coefficients compiled Rollinson (1993) and Nielsen (2007); c) (Gd/Er)n vs. MgO diagram with fields of low- to high HREE TTG and sanukitoids and hypothetic source end-members of garnetbearing or garnet-free basaltic crust or mantle (high $\mathrm{MgO}$ ) from Halla et al. (2009); d) $\mathrm{Al}_{2} \mathrm{O}_{3}$ vs. $\mathrm{SiO}_{2}$ diagram separating low- and high HREE groups from Halla et al. (2009)

Figure 4.16 - Plots for the Floresta Suite: a) Discriminant tectonic diagram after Pearce et al. (1984); b) $\mathrm{Al}_{2} \mathrm{O}_{3} /(\mathrm{FeOt}+\mathrm{MgO})-3 \mathrm{CaO}-5\left(\mathrm{~K}_{2} \mathrm{O} / \mathrm{Na}_{2} \mathrm{O}\right)$ plot with fields after Laurent et al. (2014)

Figure 4.17 - Sketch tectonic model with suggested scenarios for Riacho das Lajes (a) and Floresta suite (b) magma emplacements.

Figure 4.18 - Synthesis of obtained Nd data for rocks of the Alto Moxotó Terrane in the present and previous studies

Figure 5.1 - a) Geodynamic context of the Borborema Province in Pre-Drift reconstruction of part of West Gondwana; b) Main geological subdivision of the Borborema Province and its main geological Sub provinces; c) Terranes of the Transversal Sub Province. Rectangles $a$ and $b$ represents Figures $2 a$ and $2 b$, respectively. Cratons: $\mathrm{AC}=$ Amazonian, $\mathrm{SFC}=\mathrm{São}$ Francisco, $\mathrm{RPC}=\mathrm{Rio}$ de $\mathrm{La}$ Plata, $\mathrm{WAC}=$ West Africa, $\mathrm{SMC}=$ Saara Metacraton, $\mathrm{CC}=$ Congo, $\mathrm{KC}=$ Kalahari. Borborema Sub provinces: CCS $=$ Ceará Central, RNS $=$ Rio Grande do Norte, $\mathrm{TS}=$ Transversal, $\mathrm{SS}=$ Southern. Terranes of the Tranversal Sub Province: PABT $=$ Piancó-Alto Brigída, APT = Alto Pajeú, AMT = Alto Moxotó, $\mathrm{RCT}=$ Rio Capibaribe. 
Figure 5.2 - Simplified geological maps of the studied areas with the occurrences of the Riacho do Navio Suite, Coloete orthogneiss and Carnoió Suite

Figure 5.3 - Field aspects of the studied rocks. a) Metagranitic sheet of the Riacho do Navio Suite; b) augen gneiss facies of the Riacho do Navio Suite exhibiting eye-shape potassic feldspar up to $1,5 \mathrm{~cm}$; c) granitic gneiss fabric of the Coloete orthogneisses; d) ruptile mosaic of the Banded orthogneiss to mylonites from Coloete orthogneisses; e) intrusive contac between metatexites of the Carnoió Suite on the right side of the photo and early Paleoproterozoic banded to migmatized granitic gneiss of the Cabaceiras Complex; f) amphibole bearing alkali-feldspar syenogranitic orthogneiss of the Carnoió Suite.

Figure 5.4 - Modal composition of studied rocks reported in the Q-A-P triangle diagram from Streckeisen (1976)

Figure 5.5 - a) Granoblastic texture in metasyenogranitic rock of the Riacho do Navio Suite exhibiting oriented quartz ribbons as a result of intense deformation; b) Coloete orthogneiss with crystals of microcline, plagioclase and stretched quartz. Muscovite lamellae is also present. c) fractured syn-tectonic garnet exhibiting chlorite substitution of the Coloete orthogneisses; d) epidotization in amphibole aggregates with allanite inclusion. Garnet occur englobed by plagioclase in syenogranites of Carnoió Suite.

Figure 5.6 - Cathodoluminescence (a) and Backscattered images (c and e) of zircon grains where the white circles indicate the position of laser spots with their respectively ${ }^{207} \mathrm{~Pb} /{ }^{206} \mathrm{~Pb}$ ages and the diagrams of LA-MC-ICP-MS results of the three studied units (b, $d$ and $f)$

Figure 5.7 - Nd isotopic composition of analyzed samples of the Riacho do Navio and Carnoió suites.

Figure 5.8 - Chemical classification of the studied rocks. Fields after Debon and Le Fort (1983) 
Figure 5.9 - Geochemical characteristics (major elements) of the studied rocks. a) $\mathrm{SiO}_{2}$ vs $\mathrm{Na}_{2} \mathrm{O}+\mathrm{K}_{2} \mathrm{O}-\mathrm{CaO}$ diagram from Frost et al., (2001); b) $\mathrm{SiO}_{2}$ vs. $\mathrm{FeO} /(\mathrm{FeOt}+\mathrm{MgO})$ diagram from Frost et al., (2001); c) $\mathrm{Al}_{2} \mathrm{O}_{3} /\left(\mathrm{Na}_{2} \mathrm{O}+\mathrm{K}_{2} \mathrm{O}\right)$ molar vs. Al2O3/(CaO+Na2O+K2O) molar diagram after Maniar and Picolli, (1980)

Figure 5.10 - Chondrite-normalized spider diagrams (Nakamura, 1974) and rare earth elements (REE) patterns (Thompson, 1982) of the studied units

Figure 5.11 - Discriminating diagrams of the studied rocks. a) Rb-Hf-Ta plot from Harris et al., (1986); b) Yb vs. Ta and c) Y + Nb vs. Rb plots from Pearce et al., (1984); d) Nb-Y-Ce plot of the A-type rocks from Eby, 1992 (A1 = mantle type, A2 $=$ crustal type)

Figure 6.1 - a) Pre-drift reconstruction of Northeast South America and West Africa in West Gondwana context with the main structural provinces and lineaments. SJCT $=$ São José do Caiano Terrane, PABT $=$ Piancó Alto-Brigída Terrane, APT $=$ Alto Pajeú Terrane, AMT $=$ Alto Moxotó Terrane, $\mathrm{RCT}=$ Rio Capibaribe Terrane, TBL = Transbrasiliano Lineament, KL - Khandi Lineament, $\mathrm{PaL}=$ Patos Lineament, GAL = Garoua Lineament, PeL = Pernambuco Lineament, $\mathrm{AL}=$ Adamoua Lineament

Figure 6.2 - Geological map of the study area. Terranes: APT = Alto Pajeú, AMT = Alto Moxotó. PEALT means Pernambuco-Alagoas Terrane, which is not addressed in this paper.

Figure 6.3 - Field aspects of the main outcropping units of the studied terranes. Alto Moxotó Terrane: a) migmatized orthogneiss of tonalitic composition of the Riacho das Lajes Suite; b) Banded granodioritic orthogneiss of the Floresta Suite; c) highly deformed Riacho do Navio augen gneiss; d) tabular lens of mettagabro of the Malhada Vermelha Suite; e) migmatized biotite-paragneiss with local quartz-feldspar mobilized. Alto Pajeú Terrane; f) isotropic tonian tonalitic granite of the São Pedro Suite; g) contact zone between metahornblendite and garnet 
metagabbro of the Serrote das Pedras Pretas Suite; h) muscovite-bearing paragneiss of the São Caetano Complex

Figure 6.4 - Histogram of neodymium depleted mantle model ages ( $\mathrm{T}_{\mathrm{DM}}$ ) for metaplutonic and metasedimentary rocks of the Alto Pajeú and Alto Moxotó Terranes

Figure 6.5 - a) Depleted mantle model ages $\left(\mathrm{T}_{\mathrm{DM}}\right)$ versus latitude and $\left.\mathrm{b}\right) \mathrm{U}-\mathrm{Pb}$ zircon ages versus $\mathrm{T}_{\mathrm{DM}}$ ages of metaplutonic and metasedimentary rocks of the Alto Pajeú and Alto Moxotó terranes. The orange arrow in a) show a general trend of increasing model ages with the latitude

Figure 6.6 - Gridded $\mathrm{Nd}$ depleted mantle model age $\left(\mathrm{T}_{\mathrm{DM}}\right)$ map of the study region.

Figure $6.7-\varepsilon N d(t)$ versus $\mathrm{U}-\mathrm{Pb}$ crystallization ages diagram of the studied terranes. Symbols are the same of Figure 5. APT = Alto Pajeú Terrane, AMT = Alto Moxotó Terrane. Simbols are the same as Figure 7.5

Figure 6.8. Proposed tectonic model for the assembly of the studied terranes and their role on the subsequential evolution of the Borborema Province. SFC = São Francisco Craton, SFB $=$ Sergipano Fold Belt, PEALT $=$ Pernambuco-Alagoas Terrane, $\mathrm{AMT}=$ Alto Moxotó Terrane, $\mathrm{APT}=$ Alto Pajeú Terrane, BMJSZ $=$ Belo Monte Jeremoabo Shear Zone, PEL = Pernambuco Lineament and SJSZ = Serra de Jabitacá Shear Zone. The thick dashed yellow lines marks the main terrane boundaries (suture zones?).

Figura 8.1 - Diagrama tectônico demonstrando acreção de dois terrenos por meio de colagem frontal (Tacônico e Avalônia) nos Apalaches da Nova Inglaterra. Retirado de http://3dparks.wr.usgs.gov/nyc/valleyandridge/valleyandridge.htm......

Figura 8.2 - Representação dos dois principais processos de dispersão de terrenos modificado de Howell 1995. 
Figura 8.3 - Diagramas esquemáticos exemplificando os resultados da amalgamação de terrenos em função do mecanismo. A, B e C são terrenos de natureza indefinida, enquanto $\mathrm{A}+\mathrm{B}+\mathrm{C}$ e $\mathrm{D}+\mathrm{E}$ representam terrenos compostos. (Modificada de Howell, 1995)

Figura 8.4 - Diagrama de assembleia tectônica (hipotético), mostrando uma sequência de colagem de terrenos de afinidades (e idades) distintas através dos diversos processos de amalgamação. Notar que os eventos não são necessariamente excludentes e podem sobrepor-se no tempo (Baseado em modelos similares apresentados por Howell, 1995)......

Figura 8.5 - Distribuição geográfica das análises apresentadas por Zelek e Dickin 2013 na região de Parent-Clova (Quebec). Os círculos de cor azul escura representam rochas com idades modelo TDM mais velhas que 2,4 Ga; vermelha, amarela e azul pálido, rochas entre 2,4 e 1,64, verde e rosa entre 1,64 e 1,37 Ga, demonstrando claramente três domínios isotópicos distintos e eficiência do método na caracterização de terrenos na Província Grenville.

Figura 8.6 - Distribuição de idades modelo TDM de isótopos de Nd na Faixa Ribeira no estado de São Paulo de acordo com Dantas et al., 2000. O contraste isotópico entre os distintos domínios limitados pelas falhas de Itu, Taxaquara e Caucaia pode ser interpretado como um indício de tectônica acrescionária

Figura 8.7 - Síntese dos principais elementos utilizados na análise tectônica de terrenos

Figura 8.8 - Compartimentação tectonoestratigráfica da Província Tocantins, modificado de Fuck et al., 1994. LTB = Lineamento Transbrasiliano, FRB = Falha Rio dos Bois

Figura 8.9 - Compartimentação tectonoestratigráfica da Província Borborema, modificado de Santos et al., 2014. SMC = Subprovíncia Médio Coreaú, SCC = Subprovíncia Ceará Central, SRN = Subprovíncia Rio Grande do Norte, STR = 


\section{LISTA DE TABELAS}

Tabela 2.1 - Descrição das principais unidades da área de estudo correspondentes ao Terreno Alto Pajeú. Referências anteriores a 1990 podem ser encontradas em Santos (2001)

Tabela 2.2 - Descrição das principais unidades da área de estudo correspondentes ao Terreno Alto Moxotó. Referências anteriores a 1990 podem ser encontradas em Santos (2001)

Table 4.1 - Major (wt. \%) and trace element (ppm) concentrations of the Riacho das Lajes Suite, Alto Moxotó Terrane, NE Brazil

Table 4.2 - Major (wt. \%) and trace element (ppm) concentrations of the Floresta Suite, Alto Moxotó Terrane, NE Brazil. n.d. = not detected.

Table 4.3 - Summary of LA-ICP-MS data of zircons from sample LS-56 (Riacho das Lajes Suite).

Table 4.4 - Summary of LA-ICP-MS data of zircons from sample FL-105 (Riacho das Lajes Suite).

Table 4.5 - Summary of LA-ICP-MS data of zircons from sample LS-65 (Floresta Suite)

Table 4.6 - Summary of LA-ICP-MS data of zircons from sample LS-60 (Floresta Suite)

Table 4.7 - Summary of Nd isotope data for the metaplutonic rocks of Riacho das Lajes (R.L.S.) and Floresta Suites (F.S.) 
Table 5.1 - Summary of LA-ICP-MS data of zircons from sample FL-122 (Riacho do Navio Suite).

Table 5.2 - Summary of LA-ICP-MS data of zircons from sample FL-122 (Coloete orthogneiss).

Table 5.3 - Summary of LA-ICP-MS data of zircons from sample RS-425 (Carnoió Suite)

Table 5.4 - Summary of Nd isotope data for the sutided metaplutonites. R.N. = Riacho do Navio Suite; C.O. = Coloete orthogneiss; C.S. = Carnoió suite

Table 5.5 - Major (wt. \%) and trace element (ppm) concentrations of the Riacho do Navio Suite, Alto Moxotó Terrane, NE Brazil.....

Table 5.6 - Major (wt. \%) and trace element (ppm) concentrations of the Coloete orthogneisses, Alto Moxotó Terrane, NE Brazil

Table 5.7 - Major (wt. \%) and trace element (ppm) concentrations of the Carnoió Suite, Alto Moxotó Terrane, NE Brazil.

Table 6.1 - Summary of $\mathrm{Nd}$ isotope data for the metaplutonic and metassedinemtary rocks of the Alto Pajeú Terrane. U-Pb zircon ages was extracted from Santos (1995); Guimarães et al. (2012) and Lages and Dantas (2016)

Table 6.2 - Summary of $\mathrm{Nd}$ isotope data for the metaplutonic and metassedinemtary rocks of the Alto Moxotó Terrane. U-Pb zircon ages was extracted from Santos (2004) and Santos (2016). 


\section{Resumo}

A Província Borborema corresponde a um cinturão orogênico Neoproterozoico consolidado no final do ciclo orogênico Brasiliano (ca. 800-580 Ma), que se estende ao longo do Gondwana Ocidental por meio das Faixas Pan-Africanas. Na presente tese, o papel de possíveis processos acrescionários na amalgamação dos terrenos Alto Pajeú, Alto Moxotó e Pernambuco-Alagoas, bem como seu significado na evolução crustal deste setor do continente Gondwana são investigados. Baseado em uma série de técnicas geológicas, incluindo geologia estrutural, geoquímica elementar e isotópica, além do auxílio de geofísica aérea na região localizada entre os municípios de Floresta e Airí, Pernambuco, é sugerido que sistemáticos processos de subducção, colisão continental e acreção resultaram na configuração atual desta parte do Gondwana. No Terreno Alto Moxotó, as primeiras manifestações tectônicas são refletidas na formação de magmas do tipo TTG (Suíte Riacho das Lajes) durante o Neoarqueano (2,6 Ga). Este evento resultou na geração de crosta juvenil, advinda de fusão de basaltos em condições de alta temperatura e pressão em ambiente intra-oceânico. Um segundo evento de subducção ocorreu durante o Riaciano (ca. 2,1 Ga), representado por magmas (Suíte Floresta) resultantes de fontes heterogêneas. Tal evento, teria ainda retrabalhado intensamente a crosta arqueana envolvendo ascensão astenosférica durante acreção de terrenos coevos ao quebramento (slab break off) de litosfera oceânica. Já na transição do Estateriano para o Caliminiano (ca. 1,6 Ga), as unidades Riacho do Navio, Coloete e Carnoió, registram o último pulso tectônico deste terreno. As duas primeiras apresentam características similares a granitos do meta- a peraluminosos, típicos de um ambiente de subducção e colisão, enquanto que a última apresenta típica assinatura de granito intraplaca. A ocorrência das rochas das unidades Riacho do Navio e Coloete na margem do terreno, indicam que este se comportou como um bloco crustal quasi-rígido, que foi submetido a subducção e colisão periférica durante um maior evento de fragmentação continental. Com relação ao arranjo tectônico entre os Terreno Alto Moxotó, Alto Pajeú e Pernambuco-Alagoas, dados de magnetometria e radiometria associada a análise estrutural meso-macro e microscópica, revelaram uma complexa história deformacional. Mapas geofísicos indicam assinaturas contrastantes entre estes domínios, bem como realçam as principais estruturas da região, incluindo os limites de terrenos: i.e. Zona de Cisalhamento Serra de Jabitacá e Lineamento Pernambuco. Análise geométrica é sugestiva de aloctonia entre o Terreno Alto Pajeú (Toniano) com relação ao Alto 
Moxotó (Arqueano-Paleoproterozoico). Estruturas de cavalgamento associadas espacialmente a remanescentes de crosta oceânica (Suíte Serrote das Pedras Pretas), sugerem que a colagem entre estes domínios se deu durante a orogenia Cariris Velhos (ca. 1,0-0,9 Ga), enquanto que zonas de cisalhamento de rejeito direcional associada com foliações e lineações de transposição obliteraram estruturas prévias e marcaram a colagem lateral entre este primeiro conjunto de terrenos e o Pernambuco-Alagoas durante a orogenia Brasiliana (ca. 0,6-0,5 Ga). Outra possibilidade a ser considerada, é que a tectônica de empurrão possa ter se desenvolvido no inicio do Ediacarano. Por fim, análises Sm-Nd de 106 amostras coletadas ao longo dos Terrenos Alto Moxotó e Alto Pajeú, revelaram fontes igualmente contrastantes. O primeiro, apresenta fontes mais velhas, que variam do Arqueano ao Paleoproterozoico, enquanto que o segundo entre o Paleo- e Mesoproterozoico. Estes também apresentam processos crustais diacrônicos, registrados pela assinatura isotópica de $\mathrm{Nd}$, confirmando que se tratam de fragmentos litosféricos não contínuos. A integração dos dados obtidos neste trabalho com informações disponíveis na literatura permite sugerir que a Província Borborema, ao menos em parte, se comportou como um análogo de um orógeno acrescionário moderno.

Palavras chave: Tectônica acrescionária, Gondwana Ocidental, Província Borborema. 


\section{Abstract}

The Borborema Province corresponds to a Neoproterozoic orogenic belt that was consolidated at the end of the Brasiliano cycle (ca. 800-540 Ma), that extends to the Pan-African mobile belts trough West Gondwana. In this thesis, the role of accretionary processes on the amalgamation of the Alto Pajeú, Alto Moxotó and PernambucoAlagoas terranes, as well as its significance on the crustal evolution of this portion of Gondwana is investigated. Based on several geologic techniques, including structural geology, whole-rock and isotopic geochemistry, besides the usage of airborne geophysics in an area located between the Floresta and Airí towns, Pernambuco, it is suggested that systematic subduction processes, continent-continent collision and crustal accretion resulted in the actual tectonic framework. Within the Alto Moxotó Terrane, the first tectonic event is reflected on the formation of TTG-type magmas (Riacho das Lajes Suite) during the Neoarchean (ca. 2.6 Ga). Such episode, resulted on the generation of juvenile crust, derived from basalt melting on high pressure and temperature conditions in an intraoceanic setting. A second subduction-related event occurred during the Rhyacian period (ca. $2.1 \mathrm{Ga}$ ). It is represented by magmas (Floresta Suite) that present heterogeneous sources. Such event, reworked the Archean crust, involving asthenospheric upwelling during terrane accretion coeval to slab break off of the oceanic slab. During the Statherian-Caliminian transition (ca. $1.6 \mathrm{Ga}$ ), the Riacho do Navio, Coloete and Carnoió units record the last tectonic pulse of this terrane. The formers present similar features to meta- to peraluminous granites, typical from subduction- to collisional-related settings, whereas the latter present within-plate geochemical signature. The occurrence of the Riacho do Navio and Coloete units on the terrane margin, indicate that it represent a quasi-rigid crustal block that underwent subduction and peripheral collision, during a major event of continental break-up. Regarding the tectonic relationships between the Alto Moxotó, Alto Pajeú and Pernambuco-Alagoas terranes, airborne magnetic and radiometric data associated with mesoscopic and microscopic structural analysis revealed a complex deformational history. Geophysical maps indicate contrasting signatures between these domains, as well as highlight the main structures of the region, including the terrane boundaries: i.e. Serra de Jabitacá Shear Zone and Pernambuco Lineament. Geometric analysis suggest an allochtonous contact between the Tonian Alto Pajeú and the ArcheanPaleoproterozoic Alto Moxotó Terranes. Thrusting structures spatially associated with 
remnants of oceanic crust (Serrote das Pedras Pretas Suite), also suuggest that terrane collage occurred during the Cariris Velhos orogeny $(1.0-0.9 \mathrm{Ga})$, whereas later strikeslip shear zones with associated transposition foliations and lineations obliterate previous structures and mark lateral assembly between them and the Pernambuco Alagoas Terrane during final stages of the Brasiliano orogeny (ca. 0.6-0.5 Ga). Another possibility, is that thrust tectonics may be related to Early Ediacaran. Lastly, $106 \mathrm{Sm}-\mathrm{Nd}$ analysis of 106 samples collected in the Alto Moxotó and Alto Pajeú terranes, also revealed contrasting sources. The former presents older sources, varying from the Archean to Early Paleoproterozoic, whereas the latter Paleo- to Mesoproterozoic sources. They also show diachronic crustal processes, which is recorded by $\mathrm{Nd}$ isotopic signature, confirming that they do not correspond to continuous lithospheric fragments. The integration of the obtained data in this work with those available in the literature, suggest that the Borborema province was once an analogous of a modern accretionary orogen.

Key-words: Accretion tectonics, West Gondwana, Borborema Province. 


\section{INTRODUÇÃO}

\subsection{Apresentação e justificativa do tema proposto.}

A adição de fragmentos crustais diversos como arcos de ilhas, platôs oceânicos e trilhas de hot-spots à margens continentais, corresponde a um processo comum e particularmente importante em eventos de modificação e espessamento da crosta continental em regiões conhecidas como cinturões orogênicos (Schermer, 1984; Howell, 1995). Se tais segmentos crustais forem acrescidos aos continentes por meio de subducção e/ou colisão frontal ou oblíqua, estes serão limitados por importantes falhas ou zonas de sutura, sendo portanto denominados de terrenos tectono-estratigráficos, ou simplesmente terrenos (Coney et al., 1980). Neste âmbito, dois principais processos são responsáveis por modificação crustal e/ou espessamento crusta: colagem e acreção de terrenos.

Cinturões orogênicos que registram eventos de acreção de terrenos são chamados de Cordilheiranos ou acrescionários (Cawood et al., 2009 e referências ali contidas). Por outro lado, independente de sua origem, uma grande parcela dos orógenos conhecidos, registra ao menos um estágio de acreção ou colagem (Cawood et al., 2011). Exemplos variam desde Províncias arqueanas como Slave no Canadá, até as mais recentes, como os orógenos que compõem toda a região do Circum-pacífico (Howell et al., 1985; Moores, 1991; Nockleberg et al., 2000; Mortimer, 2004; Cawood et al., 2009). Neste sentido, análise de terrenos corresponde ao estudo detalhado da crosta em cinturões orogênicos complexos que eventualmente experimentaram episódios acrescionários, buscando remontar e organizar a história estratigráfica e tectônica entre os seus principais elementos, bem como suas relações com o continente adjacente.

Localizada na porção central de Gondwana Ocidental (Figura 1.1), a Província Borborema (PB) corresponde a um bom exemplo de sistema orogênico complexo, cuja história evolutiva parece longe de ser bem entendida. Felizmente, nas últimas décadas o conhecimento geotectônico desta província evoluiu significativamente em função do forte incremento de dados isotópicos, principalmente análises U-Pb em zircão combinados com a metodologia $\mathrm{Sm}-\mathrm{Nd}$, além do detalhamento de áreas importantes mapeadas pelo Serviço Geológico do Brasil (CPRM). 
Um dos modelos propostos, sugere para a evolução da PB uma seqüência de eventos de colagem e colisão de arcos e terrenos tectono-estratigráficos desde o Toniano até o Cambriano (Santos 1996; Brito Neves et al., 2000; Kozuch, 2003; Santos et al., 2010; Caxito et al., 2014a). Em favor desse modelo, podem ser citados os múltiplos registros de associações de rochas correspondentes a arcos magmáticos, granitos colisionais, ofiolitos preservados, além de falhas consideradas como importantes zonas de sutura com expressão geofísica considerável (Kozuch, 2003; Fetter et al., 2003; Carvalho, 2005; Oliveira 2008; Santos et al., 2010; Caxito et al., 2014b; Lima et al., 2015). A recente descoberta de fases minerais correspondentes a condições metamórficas de fácies eclogito e ultra alta pressão (UHP) associados aos limites propostos indicam que a Província Borborema foi submetida durante sua evolução à eventos de acreção crustal durante o Neoproterozoico (Beurlen et al., 1992; Lages e Dantas, 2016).

Por outro lado, Neves et al., 2006, 2015 e Neves 2015, questionam tal modelo. De acordo com estes autores, a província corresponde a orógeno puramente intracontinental sem envolvimento de processos acrescionários, colagem de terrenos e ausência de fases de oceanização neoproterozoicas. De acordo com esta proposta, após uma fase de colagem de fragmentos crustais durante o paleoproterozoico, houve apenas episódios de retrabalhamento crustal em resposta a far-field stresses até a consolidação da província na transição Ediacarano-Cambriano. A discussão acerca da natureza e presença de eventos de colagem de terrenos em orógenos Pré Cambrianos é extremamente motivadora do ponto de vista científico, estando presente em diversas faixas ao redor do planeta. A divergência gerada por esses dois modelos contrastantes e o reflexo de tais pensamentos para a compreensão dos mecanismos de amálgama do Gondwana Ocidental, representam a principal motivação para o desenvolvimento desta tese. Neste sentido, foi selecionada uma área que representa o limite entre os terrenos Alto Pajeú e Alto Moxotó, a qual possui estruturação complexa, sendo um importante alvo para a investigação de eventuais processos acrescionários que tenham afetado o interior da Província Borborema. 


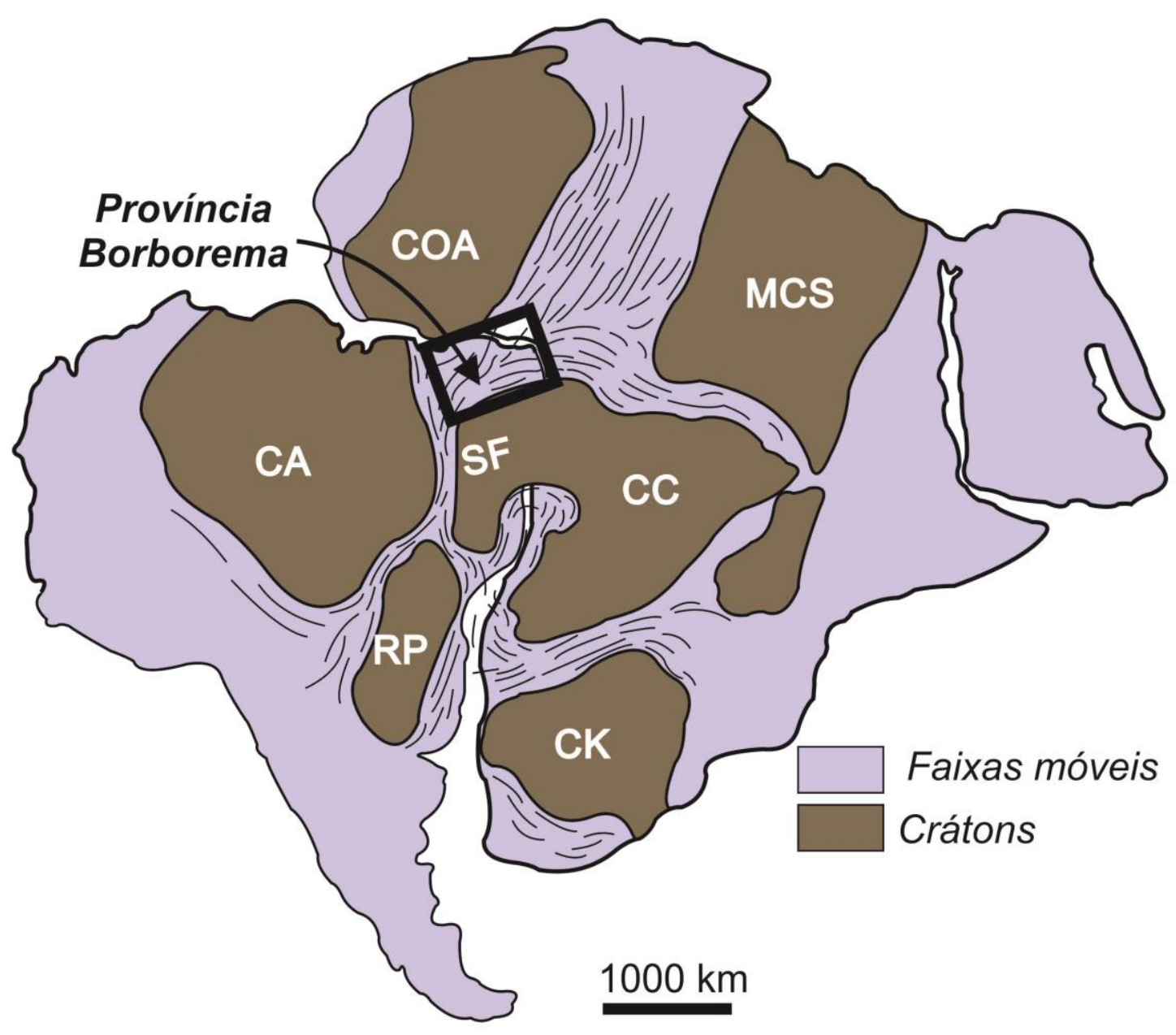

Figura 1.1 - Localização da Província Borborema no contexto do Gondwana Ocidental, em sua posição atual. Maiores blocos cratônicos: $\mathrm{CA}=$ Cráton Amazônico; $\mathrm{SF}=$ Cráton do São Francisco; RP = Cráton Rio de La Plata; COA = Cráton do Oeste-Africano; CC $=$ Cráton do Congo; $\mathrm{CK}=$ Cráton Kalahari; $\mathrm{MCS}=$ Meta Crátón do Saara .

\subsection{Objetivos}

A área de estudo proposta para o presente trabalho abrange as cidades de Airi e Floresta, no alto sertão do estado de Pernambuco (Figura 1.2). Esta região é particularmente importante para o entendimento da evolução da província, pois abrange o limite geológico entre dois domínios considerados terrenos alóctones; Alto Moxotó e Alto Pajeú da Subprovíncia Transversal. No artigo científico 3, é abordado também aspectos geológicos acerca de outra área, localizada na região de Boa Vista-PB, como forma complementar deste documento. 
Aparentemente, tais domínios apresentam padrões contrastantes de idade, condições metamórficas, associações magmáticas e fontes, sugestivos do envolvimento de processos de colagem de terrenos, os quais podem ter sido importantes para a configuração geológica da província. Entretanto, o limite entre eles é ainda mal definido, tendo sido, reconhecido como uma nappe migmatítica por alguns (nappe Serra de Jabitacá) ou zona de empurrões de Riachão do Bacamarte por outros. Desta forma, até o presente não há uma definição de uma feição estrutural regional que separe os dois domínios, nem estudos estruturais ao longo desse limite, que possa caracterizar o mecanismo de amalgamação entre eles. Em grande parte, isso é decorrente da transposição das estruturas prévias por zonas de cisalhamento transcorrentes típicas da Subprovíncia Transversal, que por sua vez, podem caracterizar episódios de dispersão dos terrenos, similares aos descritos na Cordilheira Norte-Americana (Colpron et al., 2007 e referências ali contidas).

Assim, para tentar provar a presença de tectônica acrescionária na região, pretende-se caracterizar de forma individual as principais unidades que ocorrem na área pertencentes aos dois terrenos, bem como descrever as relações estruturais existentes entre elas, sugerindo possíveis mecanismos de amálgama. Para isto, pretende-se seguir metodologia clássicas de análise de terrenos envolvendo evidências geoquímicas de rocha total e isotópica, estruturais, geofísicas e geocronológicas que sejam sugestivas de tais processos. Por fim, pretende-se apresentar as principais implicações deste estudo para a evolução da Província Borborema e seu significado na edificação Gondwana ocidental. Não obstante, o autor reconhece que tal tarefa estará longe de ser cumprida em 4 anos, o que não deixa de ser mais um fator motivador de pesquisa, quem sabe, para toda a vida.

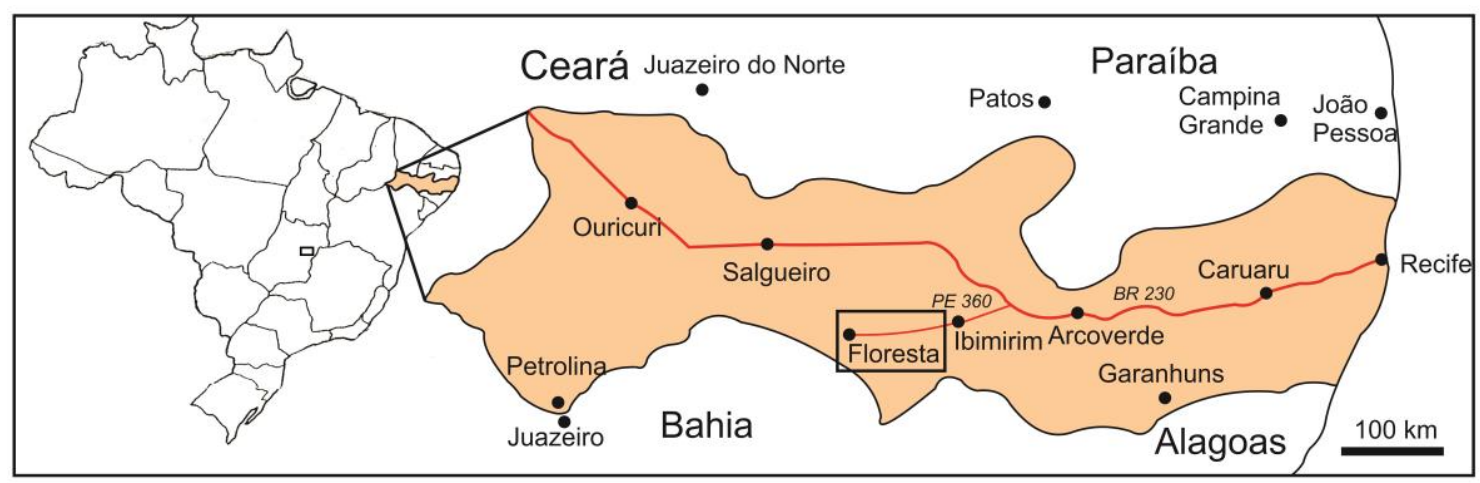

Figura 1.2 - Localização geográfica da área de trabalho (retângulo em destaque) e as principais rodovias de acesso a partir de Recife, Pernambuco. 


\subsection{Estrutura da tese}

Recentemente no Brasil, a produção de artigos científicos vem se tornando obrigatória para a sustentação dos programas de pós graduação, o que de certa forma, coincide com a tendência mundial. Apesar de reconhecer que esta é uma forma rápida e eficiente de divulgação dos resultados obtidos por dissertações e teses, acredito que a condução de tal processo é desgastante e, até prejudicial para o desenvolvimento do estudante.

Geologia em particular, é uma ciência que lida com muitas variáveis, e uma razoável compreensão destas para a formulação de modelos consistentes demanda muito tempo, leitura e, sobretudo, amadurecimento de idéias. Acredito que a pesquisa científica não pode ser refém da combinação de prazos curtos e exigências elevadas (publicação em periódicos de alto impacto, por exemplo). Não obstante, a presente tese está estruturada em cinco artigos científicos. Um breve comentário sobre tais capítulos/artigos, é feito a seguir:

Cap. 2 - Contexto Geológico: Como em todo trabalho de geologia, este capítulo tem por objetivo introduzir ao leitor um breve histórico sobre a evolução do conhecimento geológico na Província Borborema, bem como apresentar uma síntese sobre o contexto local da área de trabalho.

Cap. 3 - Artigo 1: Two-stage terrane assembly in the central portion of the Borborema Province, NE Brazil: Insights from structural geology and geophysical data. Neste trabalho, são apresentados mapas geofísicos (magnetometria e radiometria) que associados a dados macro- e microscópicos de geologia estrutural, permitem inferências sobre a evolução tectônica da Sub província Transversal, permitindo remontar a história de colagem e amalgamação entre os terrenos Alto Pajeú, Alto Moxotó e Pernambuco-Alagoas durante o Neoproterozoico. Encontra-se sob revisão no periódico Journal of Structural Geology (ISSN: 0191-8141).

Cap. 4 - Artigo 2: Neoarchean crustal growth and Paleoproterozoic reworking on the Borborema Province, NE Brazil: insights from geochemical and isotopic data of TTG and metagranitic rocks of the Alto Moxotó Terrane. Este artigo apresenta de forma inédita a identificação de crosta arqueana na Subprovíncia Transversal da Província Borborema, como primeira manifestação tectônica desde domínio, bem como 
apresenta novos elementos para geração de magmas paleoproterozoicos no interior do Terreno Alto Moxotó. Encontra-se sob revisão no periódico Journal of South American Earth Sciences (ISSN: 0895-9811).

Cap. 5 - Artigo 3: Statherian to Calyminian magmatism in the Alto Moxotó Terrane, Borborema Province, NE Brazil: implications for within plate and collision tectonics in West Gondwana. Neste artigo são apresentadas evidências geoquímicas e geocronológicas que sugerem que o Terreno Alto Moxotó experimentou processos de subducção periférica coeva à eventos de fragmentação. É também apresentada a primeira evidência de tectônica colisional para este período (ca. 1.6 Ga) na Província Borborema.

Cap. 6 - Artigo 4: Sm-Nd isotope mapping of terranes in the Transversal Subprovince of the Borborema Province, NE Brazil: implications for accretion tectonics in West Gondwana. Neste artigo é apresentada a aplicação de uma quantidade robusta de dados Sm-Nd visando demonstrar que os terrenos Alto Moxotó e Alto Pajeú, correspondem a domínios isotópicos distintos, o que sugere que tais domínios representam fragmentos litosféricos de origens diferentes.

Cap. 7 - Síntese Conclusiva. Neste capítulo é apresentado de forma objetiva a integração dos dados e as principais descobertas e interpretações da presente pesquisa e suas implicações. Adicionalmente, são colocadas sugestões para trabalhos futuros a serem desenvolvidos na região, para tentar solucionar algumas (várias) questões em aberto sobre esta porção fascinante do continente Gondwana.

Cap. 8 - Anexo 1 - Artigo Análise tectônica de Terrenos: metodologia, aplicação em cinturões orogênicos e exemplos das províncias Tocantins e Borborema, Brasil. Este artigo apresenta uma revisão sobre o histórico dos principais conceitos relacionados a tectônica acrescionária e colagem de terrenos. Além disto, são citados elementos tectônicos que justificam a aplicação do modelo de terrenos nas províncias Tocantins e Borborema. A inexistência de trabalhos desta natureza em português, bem como o desconhecimento por parte dos pesquisadores que trabalham com geotectônica no Brasil sobre o tema, foram as principais motivações para sua elaboração. Publicado no periódico Geonomos da UFMG (ISSN: 0104-4486). 


\subsection{Referências}

Beurlen, H., Silva, A.F., Guimarães, I.P., Barreto, S.B. 1992. Proterozoic C-type eclogites hosting unusual Ti-Fe-Cr-Cu mineralization in northeastern Brazil. Precambrian Research 58, 195-214.

Brito Neves, B.B., Santos, E.J., Schmus, W.R.Q., 2000. Tectonic history of the Borborema Province. In: Umberto Cordani; Edson José Milani; Antonio Thomaz Filho; Diogenes de Almeida Campos (Org.). Tectonic Evolution of South America. Rio de Janeiro: 31st International Geological Congress, pp. 151-182. Special Publication.

Cawood, P.A.; Kroner, A.; Collins, W.J.; Kusky, T.M.; Mooney, W.D.; Windley, B.F. 2009. Accretionary orogens through earth history. Geological Society London Special Publications 318, 1-36.

Cawood, P. A., Leitch, E.C., Merle, R.E., Nemchin, A.A. 2011. Orogenesis without collision: Stabilizing the Terra Australis accretionary orogen, eastern Australia. Geological Society of America Bulletin 123, 2240-2255.

Carvalho, M.J., 2005. Evolução tectônica do domínio Marancó-Poço Redondo: Registro das orogêneses Cariris Velhos e Brasiliana na Faixa Sergipana, NE do Brasil. Universidade Estadual de Campinas, Campinas, p. 192 (Tese de doutorado).

Caxito, F.A., Uhlein, A., Dantas, E.L. 2014a. The Afeição augen-gneiss suíte and the record of the Cariris Velhos Orogeny (1000-960 Ma) within the Riacho do Pontal fold belt, NE Brazil. Journal of South American Earth Sciences 51, 12-27.

Caxito, F.A., Uhlein, A. Ross, S., Uhlein, G.J. 2014b. Neoproterozoic oceanic crust remmants in northeast Brazil. Geology 42, 387-390.

Cawood, P.A.; Kroner, A.; Collins, W.J.; Kusky, T.M.; Mooney, W.D.; Windley, B.F. 2009. Accretionary orogens through earth history. Geological Society London Special Publications 318, 1-36.

Colpron, M., Nelson, J.L., Murphy, D.C. 2007. Northern Cordilleran terranes and their interactions trough time. GSA Today 17, 4-10.

Coney, P.J., Jones, D.L., Monger, J.W.H. 1980. Cordilleran suspect terranes. Nature 288, 329-333. 
Fetter, A.H., Van Schmus, W.R., dos Santos, T.J.S., Arthaud, M., Nogueira Neto, J., Arthaud, M. 2000. U-Pb and Sm-Nd geochronological constraints on the crustal evolution and basement architecture of Ceara State, NW Borborema Province, NE Brazil: implications for the existence of the Paleoproterozoic supercontinent Atlantica. Revista Brasileira de Geociencias 30, 102-106.

Howell, D.G., Jones, D.L., Schermer, E.R., 1985. Tectonostratigraphic terranes of the Circum-Pacific region. In: Howell, D.G. (Ed.) Tectonostratigraphic Terrnes of the Circum-Pacific Region. Council for Energy and Mineral Resources. Earth Science Series 1, 3-30.

Howell, D.G. 1995. Principles of Terrane analysis. Chapman \& Hall, 245 pp.

Kozuch, M., 2003. Isotopic and trace element geochemistry of Early Neoproterozoic gneissic and metavolcanic rocks in the Cariris Velhos Orogen of the Borborema Province, Brazil, and their bearing tectonic setting (Tese de Doutorado). Kansas University, Lawrence, p. 199.

Lages, G.A., Dantas, E.L. 2016. Floresta and Bodocó Mafic-Ultramafic Complexes, western Borborema Province, Brazil: geochemical and isotope constraints for evolution of a Neoproterozoic arc environment and retro-eclogitic hosted Ti-mineralization. Precambrian Research 280, 95-119.

Lima, V.A.G., Berrocal, J., Soares, J.E.P., Fuck, R.A. 2015. Deep seismic reflection experiment in Northeast Brazil: new constraints for Borborema Province evolution. Journal of South American Earth Sciences 58, 335-349.

Moores, E.M., 1991. Southwest U.S.-East Antarctic (SWEAT) connection; a hypothesis: Geology 19, 425-428.

Mortimer, N., 2004. New Zealand's geological foundations. Gondwana Research 7, 261-272.

Neves, S.P., 2015. Constraints from zircon geochronology on the tectonic evolution of the Borborema Province (NE Brazil): widespread intracontinental Neoproterozoic reworking of a Paleoproterozoic accreationary orogeny. Journal of South American Earth Sciences 58, 150-164. 
Neves, S.P., Bruguier, O., Vauchez, A., Bosch, D., Silva, J.M.R., Mariano, G., 2006. Timing of crustal formation, deposition of supracrustal sequences and Transamazonian and Brasiliano metamorphism in eastern Borborema Province (NE Brazil): Implications for western Gondwana assembly. Precambrian Reearch. 149, 197-216.

Neves, S.P., Bruguier, O., Silva, J.M.R., Mariano, G., Da Silva Filho, A.F., Teixeira, C.M.L., 2015. From extension to shortening: dating the onset of the Brasiliano Orogeny in eastern Borborema Province (NE Brazil Journal of South American Earth Sciences $58,238-256$.

Nockleberg, W.J., Parfenov, L.M., Monger, J.W.H.M., Norton, I.A., Khanchuk, A.I., Stone, D.B., Scotese, C.R., Scholl, D.W., Fujita, K., 2000. Phanerozoic Tectonic Evolution of the Circum-North Pacific. USGS Professional Paper 1626, 122 pp.

Oliveira, R.G., 2008. Arcabouço Geofísico, Isostasia e causas do magmatismo cenozóico da Província Borborema e de sua Margem Continental (NE do Brasil) (Tese de Doutorado) Universidade Federal do Rio Grande do Norte, Natal, p. 411.

Santos, E.J., 1996. Ensaio preliminar sobre terrenos e tectônica acrecion_aria na Província Borborema. In: SBG, Congresso Brasileiro de Geologia, 39º, Salvador, Proceedings, pp. 47-50.

Santos, E.J., Van Schmus,W.R., Kozuch, M., Brito Neves, B.B., 2010. The Cariris Velhos tectonic event in northeast Brazil. J. South Am. Earth Sci. 29, 61-76.

Schermer, E., Howell, D.G., Jones, D.L. 1984., The origin of allochtonous terranes: perspectives on the growth and shaping of continents. Annual Reviews of Earth and Planetary Sciences 12, 107-131. 


\section{CONTEXTO GEOLÓGICO}

\subsection{Província Borborema}

A área de estudo da presente tese encontra-se inserida na Subprovíncia ou Zona Transversal (porção central) da Província Borborema (PB). Esta província foi definida por Almeida et al., (1981), como a região Pré Cambriana localizada na porção NE da Plataforma Sul-Americana, sendo limitada nas porções norte e sul pelos crátons São Luis e São Francisco respectivamente, a oeste pela Bacia do Parnaíba e leste pelas bacias costeiras. Seu arcabouço regional foi pioneiramente detalhado por Brito Neves (1975), o qual a definiu como um complexo sistema de dobramentos estruturado no final do Neoproterozoico durante a orogenia Brasiliana ( 0,6 Ga). Este autor destacou, dentre outros aspectos, a presença de maciços medianos, importantes lineamentos e zonas de cisalhamento de caráter regional, além de múltiplas intrusões graníticas.

Na década de 1980, foram introduzidos conceitos referentes à formação de faixas monocíclicas e policíclicas como componentes importantes na configuração da província. Estes trabalhos baseavam-se fortemente em análises estruturais e correlações regionais, tais como mostram Jardim de Sá et al., (1981). De acordo com estes autores, a província teria se formado por intenso retrabalhamento de crosta paleoproterozoica ao final do evento brasiliano. Este modelo foi posteriormente consolidado por Jardim de Sá (1994), o qual dividiu a província em três tipos crustais: 1) faixas monocíclicas brasilianas, 2) faixas monocíclicas paleoproterozoicas e 3) faixas paleoproterozoicas retrabalhadas durante o brasiliano.

Já na década de 1990, os primeiros estudos baseados em geocronologia U-Pb em zircão demonstraram que a PB possuía uma evolução ainda mais complexa. Van Schmus et al., (1995) dividiram a província em três grandes domínios; i) Setentrional, ii) Transversal e iii) Meridional, separados pelos extensos lineamentos Patos e Pernambuco de direção E-W. Contribuições de destaque desta década, incluem ainda as datações de rochas supracrustais neoproterozoicas da Faixa Seridó, a descoberta do evento orogênico Cariris Velhos, de idade toniana (ca. 1,0 Ga), além da individualização de núcleos arqueanos como o São José do Campestre (Brito Neves et al., 1995; Santos, 1995; Van Schmus et al., 1995; Dantas, 1997). Paralelamente, Santos (1996) consolidou a proposta do modelo de terrenos tectono-estratigráficos para toda a 
província, incluindo a descrição de eventos acrescionários e colisionais, com destaque para a Subprovíncia Transversal. Este domínio, por sua vez, (alvo da presente investigação) foi subseqüentemente dividido em quatro terrenos: Rio Capibaribe, Alto Moxotó, Alto Pajeú e Piancó-Alto Brígida (Santos e Medeiros, 1999; Brito Neves et al., 2000).

O estado de conhecimento atual da Província Borborema (Figura 2.1) é definido por sua subdivisão em cinco subprovíncias ou domínios geotectônicos distribuídos de norte para sul como: Médio Coreaú, Ceará Central, Rio Grande do Norte, Transversal e Meridional (Brito Neves et al., 2000 e referências ali contidas). Distribuídos ao longo dessas subprovíncias, ocorrem núcleos arqueanos, ampla exposição de ortognaisses e migmatitos de idade paleoproterozoica, cinturões de rochas supracrustais estaterianas e meso- a neoproterozoicas, além de diversas associações de rochas graníticas associadas a arcos magmáticos ediacaranos, relacionados a orogenia brasiliana (Almeida et al. 1967; Sial et al., 1997; Fetter et al., 2003; Van Schmus et al., 2008; Santos et al., 2010; Dantas et al., 2010; Brito Neves et al., 2014). A estruturação geral deste conjunto é controlada por complexas redes de zonas de cisalhamento e lineamentos que possuem continuação para as faixas pan-africanas. Adicionalmente, algumas dessas estruturas são interpretadas como importantes zonas de suturas materializadas por extensos corredores miloníticos, com destaques para os lineamentos Transbrasiliano, Patos e Pernambuco (Vauchez et al., 1992; Jardim de Sá, 1994; Brito Neves et al., 2000; Archanjo et al., 2008; Cordani et al., 2013).

Investigações geológicas e geofísicas recentes tem demonstrado evidências sugestivas de tectônica acrescionária e colisional neoproterozoica na $\mathrm{PB}$, incluindo associações de arcos magmáticos, remanescentes de crosta oceânica preservados, fases minerais de alto grau metamórfico, além da associação destes elementos com zonas de cisalhamento de caráter regional a continental (Jardim de Sá 1994; Santos 1995; Kozuch, 2003; Amaral et al., 2011; Caxito et al., 2014a,b; Araújo et al., 2014a,b; Santos et al., 2014; Lima et al., 2015; Lages e Dantas 2016; Padilha et al., 2016). Apesar do aparente consenso por parte dos pesquisadores, tais evidências vem sendo sistematicamente contestado por Neves et al., 2003, 2006, 2015. Estes autores baseados principalmente em dados litogeoquímicos e compilações geocronológicas apontam uma série de problemas para aplicação do modelo na Província Borborema, sugerindo que a província teria sido submetida a uma orogênese intracontinental. Dentre outros aspectos, 
os referidos autores alegam, por exemplo, que há ausência de evidências claras de zonas de sutura, além de questionarem a natureza colisional-orogênica do evento Cariris Velhos, o qual é considerado como responsável pela colagem de alguns dos terrenos na região (Kozuch, 2003; Santos et al., 2010; Caxito et al., 2014a; Padilha et al., 2016).

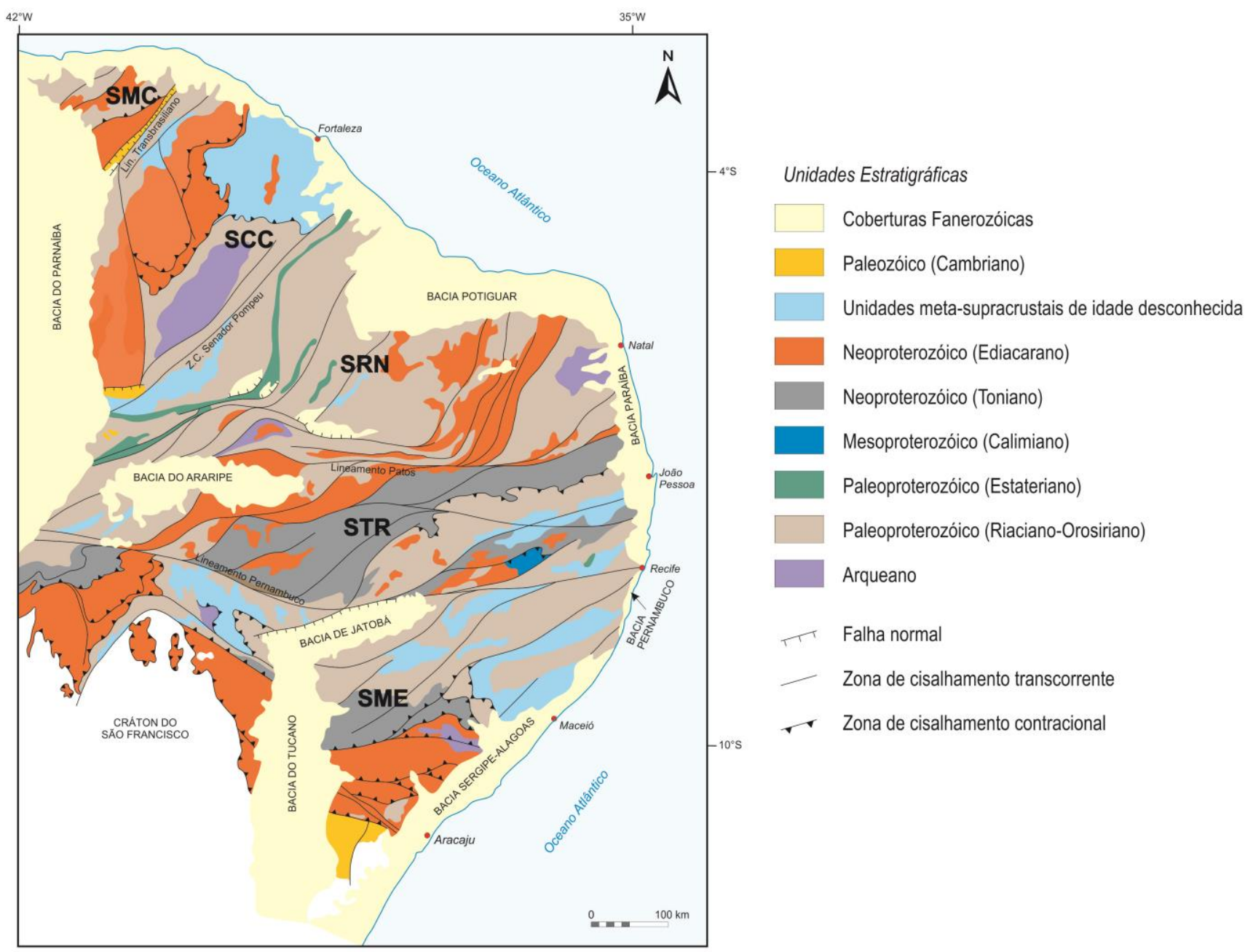

Figura 2.1 - Subdivisão geotectônica da Província Borborema com e idade dos diversos segmentos crustais. Modificado de vários autores (eg. Santos, 1996; Brito Neves et al., 2000; Van Schmus et al., 2008). Siglas das subprovíncias: SMC = Médio Coreaú, SCC $=$ Ceará Central; SRN = Rio Grande do Norte; STR = Transversal SME = Meridional. 


\subsubsection{Subprovíncia Transversal (SPT)}

A Subprovíncia Transversal (Figura 2.2) corresponde à região tectônica limitada pelos lineamentos Patos e Pernambuco. Esta região é caracterizada por uma série de terrenos ou domínios dispostos em uma trama geral de direção ENE-WSW separados por importantes zonas de cisalhamento, cobrindo geograficamente, boa parte dos estados da Paraíba e Pernambuco.

Distinguem-se na SPT, de leste para oeste, os terrenos Rio Capibaribe (TRC), Alto Moxotó (TAM), Alto Pajeú (TAP) e Piancó Alto-Brígida (TPAB) ou faixa Cachoeirinha, abrangendo associações de rochas com idade variando desde o Arqueano até o Cambriano (Santos 1996; Santos e Medeiros 1999; Brito Neves et al., 2000; Kozuch 2003; Medeiros 2004; Oliveira 2008; Van Schmus et al., 2011). Além destes, o Terreno Araripina (TA), também chamado de São José do Caiano ocorre no extremo oeste da subprovíncia. Entretanto, sua geologia é ainda pouco conhecida e não abordada na presente tese.

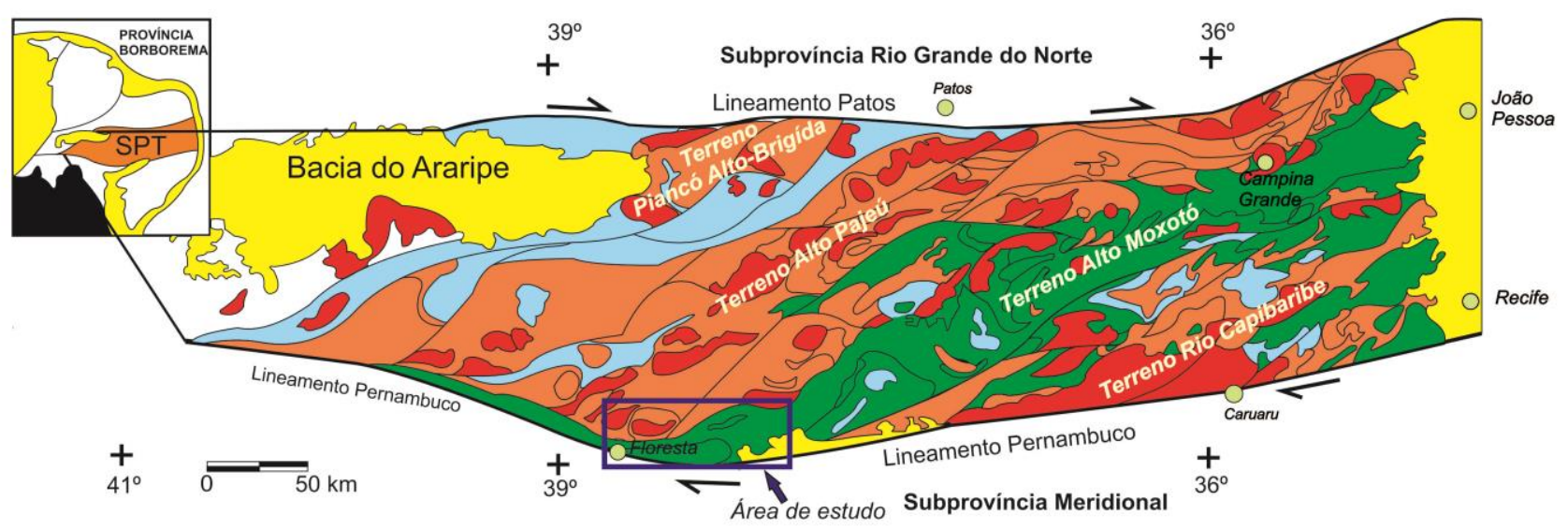

\section{Legenda}

Coberturas sedimentares fanerozoicas

Rochas ígneas plutônicas brasilianas (Ediacarano)

Rochas supracrustais neoproterozoicas (Ediacarano)

Associações diversas neoproterozoicas (Toniano)

Sequências de ortognaisses e rochas supracrustais paleoproterozoicas

$\checkmark$ Lineamentos estruturais

Figura 2.2 - Mapa de distribuição dos terrenos da Subprovíncia Transversal compilado de vários autores com a área de estudo delimitada pelo retângulo azul marinho. 
De acordo com os autores supracitados, estes terrenos teriam sido justapostos por dois eventos orogênicos sucessivos: Cariris Velhos e Brasiliano de idades toniana $(1000$ - $920 \mathrm{Ma})$ e ediacarana $(800$ - $500 \mathrm{Ma})$ respectivamente. Uma característica marcante de parte dos terrenos da SPT é a presença de volumosos batólitos e stocks graníticos cálcio-alcalinos de idade ediacarana, principalmente no interior do TPAB. As principais características petrográficas e geoquímicas dessas rochas foram sintetizadas por Sial et al., (2015) e Brito Neves et al., (2016, sob revisão). Os principais limites atribuídos aos referidos terrenos são representados por falhas ou zonas de cisalhamento de extensão regional; assim definidos:

a) Limite TA-TPAB = Zona de Cisalhamento Boqueirão dos Cochos;

b) Limite TPAB-TAP = Zona de Cisalhamento Riacho do Caboclo;

c) Limite TAP-TAM = Nappe ou sistema de empurrões Serra de Jabitacá;

d) Limite TAM-TRC = Zona de cisalhamento Congo ou Congo-Cruzeiro do Nordeste.

Em função do objetivo principal da tese ser estudar a região correspondente ao limite entre os terrenos Alto Pajeú e Alto Moxotó, uma breve descrição destes dois domínios é a seguir apresentada. O Terreno Pernambuco-Alagoas, por outro lado, faz parte da Subprovíncia Meridional, sendo apenas abordado apenas em um dos artigos da tese (ver cap. 6).

\subsubsection{Terreno Alto Moxotó (TAM)}

O Terreno Alto Moxotó (TAM) corresponde a um bloco paleoproterozoico caracterizado por diversas associações de alto grau metamórfico (Santos, 1977; Lima et al., 1985; Santos 1995; Santos, 1996, Santos e Medeiros 1999; Brito Neves et al., 2001; Santos et al., 2004; Rodrigues e Brito Neves 2008; Almeida et al., 2009; Santos et al., 2013). As principais unidades regionais reconhecidas neste terreno correspondem a diversos complexos de rochas metaplutônicas e migmatíticas e à rochas paraderivadas pelíticas com biotita, granada e sillimanita, localmente migmatizados atribuídas regionalmente ao chamado Complexo Sertânia. É sugerido ainda que parte dessas 
unidades tenha sido envolvida em um grande evento orogênico Riaciano-Orosiriano que culminou com o desenvolvimento de zonas de sutura importantes naquela época (Santos et al., 2012a; Santos et al. 2015 e referências ali contidas).

Uma das características marcantes do TAM é a ausência de rochas mais jovens que 1,6 Ga, exceto por ocorrências pontuais de granitos anorogênicos cambrianos que variam de 590 a 540 Ma (Guimarães et al., 2005; Holanda et al., 2010). Estes dados indicam que este terreno comportou-se como um bloco rígido desde o final do paleoproterozoico. Estas conclusões são também suportadas por recentes estudos geofísicos (eg. Santos et al., 2014; Padilha et al., 2016). A compilação da evolução tectônica de diversos autores permite agrupar a estratigrafia do TAM com base em três episódios tectônicos principais:

I) Sideriano: evento de retrabalhamento crustal de crosta arqueana mais antiga (ainda não identificada) próximo a 2,4 Ga. Este evento é responsável pela formação de arcos magmáticos continentais gerando ortognaisses e migmatítos atribuídos ao embasamento do terreno. Rochas com características similares são descritas na região de Cabaceiras e Mulungu (estado da Paraíba).

II) Riaciano: evento de retrabalhamento de crosta Sideriana, com geração de material juvenil em ambiente de subducção. São atribuídos a este evento a geração de suítes máficas a ultramáficas e rochas intermediárias datadas entre 2,15 e 2,0 Ga, amplamente distribuídas ao longo de todo o terreno. Uma grande zona de sutura pode ter se desenvolvido durante este período seguido por um período de relaxamento do órogeno no orisiriano.

III) Estateriano-Caliminiano: evento essencialmente de extensão e fragmentação de crosta, representado por magmatismo plutônico bimodal. Este evento marca o fim da evolução paleoproterozoica do terreno, consolidando-o como um segmento continental estável único em meio a um arranjo de terrenos Neoproterozoicos. 


\subsubsection{Terreno Alto Pajeú (TAP)}

O Terreno Alto Pajeú (TAP) é representado por três associações litológicas importantes: i) uma seqüência formada por rochas metassedimentares, metavulcânicas e metaplutônicas com assinatura geoquímica de arco magmático, datadas entre 1,0 e 0,9 Ga relacionadas ao evento orogênico Cariris Velhos, ii) granitos cálcio-alcalinos de 0,65 a $0,52 \mathrm{Ga}$ correspondentes à orogenia brasiliana e iii) exposições locais de embasamento de distribuição descontínua e idade entre 2,2 e 2,1 Ga, interpretadas como remanescentes de crosta mais antiga subjacente a algumas porções do terreno (Kozuch, 2003; Medeiros, 2004; Santos et al., 2010; Van Schmus et al., 2011). Este terreno é particularmente importante no contexto da Província Borborema, pois corresponde à região tipo do evento Cariris Velhos. Ao longo deste, ocorre uma faixa de rochas tonianas com assinatura geoquímica de arco magmático com aproximadamente $100 \mathrm{~km}$ de largura que se prolonga por mais de $700 \mathrm{~km}$, denominada por alguns como Cinturão ou Faixa Cariris Velhos (Santos et al., 2010; Van Schmus et al., 2011). Registros de associações geneticamente similares são bem documentadas em outros domínios, tais como no terreno Marancó-Poço Redondo da Faixa Sergipana, na faixa Riacho do Tigre do TRC e augen gnaisse Afeição da Faixa Riacho do Pontal (Carvalho 2005; Oliveira et al., 2010; Caxito et al., 2014a).

As associações de rochas mais importantes da Faixa Cariris Velhos correspondem a rochas metavulcânicas e metavulcanoclásticas que ocorrem na porção sul do terreno Alto Pajeú (Complexo Lagoa das Contendas e seqüência Poço do Salgueiro), rochas metavulcanossedimentares formadas principalmente por biotitamuscovita paragnaisses e biotita-muscovita xistos e anfibolitos do Complexo São Caetano (Santos 1995; Sales et al., 2011), além de metariolitos e metariodacitos do chamado subterreno Riacho Gravatá (Kozuch 2003; Medeiros 2004; Santos et al., 2010; Van Schmus et al., 2011). Recentemente, o Complexo Salgueiro foi datado também como de idade toniana (ca. $962 \mathrm{Ma}$, Brito, 2014), o que pode sugerir que a parte oeste do TPAB, na realidade, pertence ao TAP. Por outro lado, rochas de idade similar foram encontradas ao sul do Lineamento Pernambuco por essa mesma autora, ampliando ainda mais a influência do evento Cariris Velhos na organização da Província Borborema.

O dado mais recente de um registro toniano no TAP é o de rochas metamáficas e metaultramáficas da suíte Serrote das Pedras Pretas (metadunitos, metapiroxenitos, e 
metagabros), interpretados como rochas cumuláticas da raiz de um arco magmático e ofiolitos (Lages e Dantas, 2016). Além disso, os metagranitoides e ortognaisses relacionados ao evento Cariris Velhos foram detalhados por Santos, (1995), Kozuch (2003) e Santos et al., (2010), os quais enfatizam sua natureza sin-orogênica à colisional, confirmando a natureza geotectônica deste evento. A limitada ocorrência de embasamento paleoproterozoico e abundância de rochas relacionadas aos arcos magmáticos neoproterozoicos, que se estendem desde o Toniano até o Ediacarano, são algumas das peculiaridades do TAP.

\subsection{Breve descrição da geologia da região de Airi (PE)}

A região de Airi (PE) corresponde a uma área particularmente interessante para estudo de possíveis processos acrescionários que tenham afetado a porção central da Província Borborema. A geologia desta região foi estudada pioneiramente por Lima et al., (1985) e Veronese et al., (1985), os quais definiram algumas das principais unidades da área por meio do projeto ferro-titanado de Floresta (oeste de Airi), desenvolvido pelo Radam Brasil. Posteriormente, as investigações conduzidas por Santos (1995, 2001) merecem especial destaque, pois descrevem de forma detalhada a importância de eventos convergentes na geração da maioria das rochas nesta região, incluindo a definição do evento Cariris Velhos, como um importante episódio de subducção neoproterozoica. Recentemente, Lages e Dantas (2016) detalharam as ocorrências e a gênese das mineralizações de Fe-Ti de Floresta, bem como datou e definiu novos parâmetros petrogenéticos que confirmam o caráter orogênico do Evento Cariris Velhos, contestado anteriormente por Guimarães et al., (2012 e referências ali contidas).

A área de estudo do presente trabalho apresenta $1370 \mathrm{~km}^{2}$ estendendo-se para oeste até o município de Floresta-PE (Figura 2.3). Na porção NNW ocorrem rochas do Terreno Alto Pajeú, incluindo rochas supracrustais do Complexo São Caetano, rochas metagraníticas tonianas, a suíte máfica-ultramáfica Serrote das Pedras Pretas, além de suites graníticas Brasilianas, incluindo o granodiorito Ediacarano Riacho do Icó (Tabelas 1 e 2). No âmbito do Terreno Alto Moxotó, ocorrem dois pacotes de rochas de natureza distintas: i) rochas de origem metaplutônica; suítes Floresta, Riacho das Lajes, Malhada Vermelha e Riacho do Navio e ii) seqüências de rochas supracrustais pelíticas 
do Complexo Sertânia. Como já mencionado, a Nappe Serra de Jabitacá é considerada uma mega-estrutura que limita os terrenos, tendo grande expressão regional (Santos, 1995, 2001; Brito Neves et al., 2000). Por outro lado, extensas zonas de cisalhamento transcorrentes de direções NE-SW e E-W, incluindo o Lineamento Pernambuco, cortam praticamente todas as unidades, sendo responsáveis pela estruturação predominante. As tabelas 2.1 e 2.2, apresentam as descrições disponíveis na literatura atual, sobre essas unidades, as quais encontram-se definidas em maior detalhe no relatório da Folha Belém do São Francisco de Santos (1995).

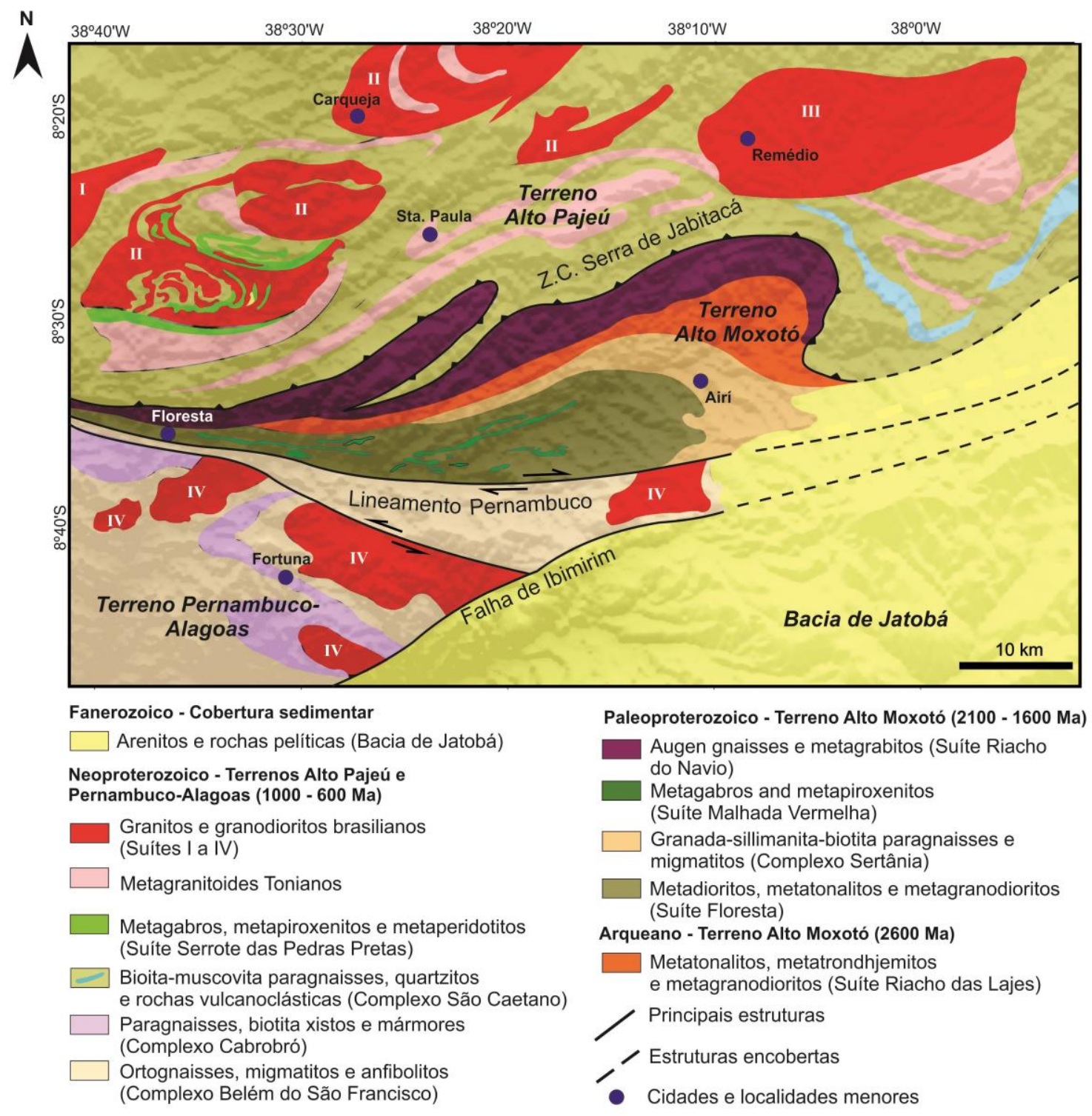

Figura 2.3 - Mapa geológico da região de Airí. Suítes graníticas Brasilianas: I = Serra do Arapuá ; II = Riacho do Icó, III = Quixaba, IV = Fortuna. 


\begin{tabular}{|c|c|c|c|}
\hline Unidade & Descrição & Idade & Trabalhos Anteriores \\
\hline $\begin{array}{l}\text { Complexo São } \\
\text { Caetano. }\end{array}$ & $\begin{array}{l}\text { Biotita-muscovita paragnaisses e biotita-muscovita xistos de } \\
\text { coloração cinza clara a cinza escura intercalados com rochas } \\
\text { metavulcânicas (metapiroclásticas e metatufos). }\end{array}$ & $\begin{array}{lll}1,089 & \mathrm{Ga} & \text { (Santos } \\
1995) . & & \\
\end{array}$ & $\begin{array}{l}\text { Santos (1971); Veiga Jr e } \\
\text { Ferreira (1990); Santos } \\
\text { (1995); Santos } \\
\text { Santos (2001). }\end{array}$ \\
\hline $\begin{array}{l}\text { Metagranitoites } \\
\text { tonianos }\end{array}$ & $\begin{array}{l}\text { Metamonzogranitos à metagranodioritos leucocráticos com } \\
\text { hornblenda e biotita como principais fases acessórias, alongados na } \\
\text { direção E-W em função da transcorrência brasiliana. }\end{array}$ & $\begin{array}{l}\text { 1,0 Ga - U-Pb TIMS } \\
\text { (Santos 1995). }\end{array}$ & Santos (1995 e 2001). \\
\hline $\begin{array}{l}\text { Suíte Serrote das } \\
\text { Pedras Pretas. }\end{array}$ & 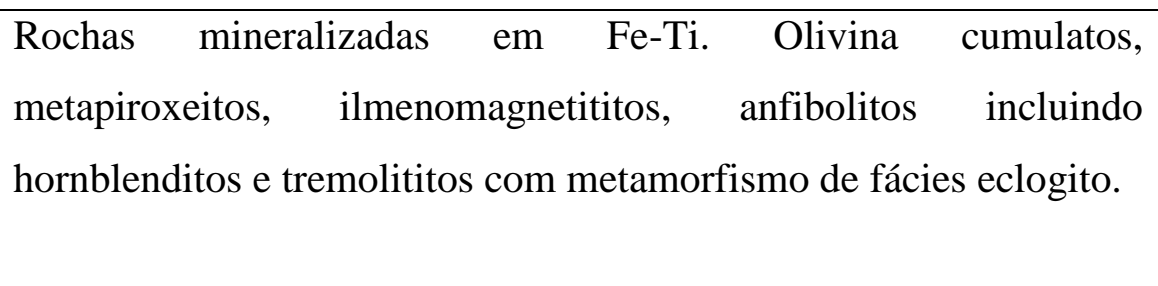 & $\begin{array}{l}0,95 \mathrm{Ga}-\text { Isócrona } \\
\text { Sm-Nd (Lages e } \\
\text { Dantas 2014). }\end{array}$ & \begin{tabular}{llr}
\multicolumn{3}{l}{ Lima et al., (1985); Beurlen } \\
(1988); & Santos & (1995); \\
Santos & (2001); & Lages \\
(2014). & &
\end{tabular} \\
\hline $\begin{array}{l}\text { Granodiorito } \\
\text { Riacho do Icó. }\end{array}$ & $\begin{array}{l}\text { Granodioritos grossos equigranulares com biotita e hornblenda } \\
\text { como minerais acessórios. Inclui megaxenólitos de rochas do } \\
\text { Complexo São Caetano e Serrote das Pedras Pretas. }\end{array}$ & $\begin{array}{l}0,608 \mathrm{Ga}-\mathrm{U}-\mathrm{Pb} \\
\text { SHRIMP (Santos et } \\
\text { al., 2014) }\end{array}$ & $\begin{array}{l}\text { Santos (1995); Santos } \\
\text { (2001); Santos et al., (2014). }\end{array}$ \\
\hline
\end{tabular}

Tabela 2.1 - Descrição das principais unidades da área de estudo correspondentes ao Terreno Alto Pajeú. Referências anteriores a 1990 podem ser encontradas em Santos (2001). 


\begin{tabular}{|c|c|c|c|}
\hline Unidade & Descrição & Idade & Trabalhos Anteriores \\
\hline $\begin{array}{l}\text { Complexo } \\
\text { Sertânia }\end{array}$ & $\begin{array}{l}\text { Considerada a sequência supracrustal característica do TAM. } \\
\text { Granada-biotita paragnaisses, raros sillimanita-biotita-granada } \\
\text { paragnaisses e migamtitos, com raras intercalações de mármores e } \\
\text { anfibolitos. }\end{array}$ & $\begin{array}{lll}2,126 & - & \mathrm{U}-\mathrm{Pb} \\
\text { SHRIMP } & \text { Ga } & \text { (Santos } \\
\text { et al., 2004). }\end{array}$ & $\begin{array}{l}\text { Santos (1977); Santos (1995); } \\
\text { Santos (2001); Santos et al., } \\
\text { (2004). }\end{array}$ \\
\hline $\begin{array}{l}\text { Suíte Riacho das } \\
\text { Lajes }\end{array}$ & $\begin{array}{lccc}\text { Associação com } & \text { afinidade } & \text { TTG } & \text { (metagranodioritos, } \\
\text { metatrondhemitos, } & \text { metatonalitos } & \text { e } & \text { metamonzodioritos) } \\
\text { intercalados com rochas do Complexo Sertânia. }\end{array}$ & $\begin{array}{l}\text { Não datada } \\
\text { anteriormente. }\end{array}$ & Santos (1995); Sant \\
\hline $\begin{array}{l}\text { Augen-gnaisse } \\
\text { Riacho do Navio }\end{array}$ & $\begin{array}{l}\text { Augen gnaisses formando tectonitos-S de composições monzo e } \\
\text { sienograníticas. }\end{array}$ & $\begin{array}{l}1,99 \mathrm{Ga}-\mathrm{Rb}-\mathrm{Sr} \\
\text { (Lima et al., 1985). }\end{array}$ & $\begin{array}{l}\text { Lima et al., (1985); Santos } \\
\text { (1995); Santos et al., (2001). }\end{array}$ \\
\hline
\end{tabular}

Tabela 2.2 - Descrição das principais unidades da área de estudo correspondentes ao Terreno Alto Moxotó. Referências anteriores a 1990 podem ser encontradas em Santos (2001). 


\subsection{Referências}

Almeida, C.N., Guimarães, I.P., Beurlen, H., Topistch, W., Ferrer, D.M.M. 2009. Evidências de metamorfismo de alta pressão na faixa de dobramentos Pajeú-Paraíba, Província Borborema, Nordeste do Brasil. Revista Brasileira de Geociências 39, 421434.

Almeida, F.F.M., Hasui, Y., Brito Neves, B.B., Fuck, R.A., 1981. Brazilian structural provinces: an introduction. Earth Science Reviews 18, 1-29.

Almeida, F.F.M., Leonardos Jr, O.H., Valença, J. 1967. Granitic rocks of Northeast South America. In: International Union of Geologica Sciences, IUGS/UNESCO, 37 p.

Almeida, F.F.M., Hasui, Y., Brito Neves, B.B., Fuck, R.A., 1981. Brazilian structural provinces: an introduction. Earth Science Reviews 18, 1-29.

Amaral, W.S., Santos, T.J.S.,Wernick, E., Nogueira Neto, J.A., Dantas, E.L., Matteini, M. 2012. High-pressure granulites from Cariré, Borborema Province, NE Brazil: tectonic setting, metamorphic conditions and U-Pb, Lu-Hf and Sm-Nd geochronology. Gondwana Research 22, 892-909.

Araujo, C.E.G., Cordani, G.U., Weinberg, R., Basei, M.A.S., Armostrong, R., Sato, K. 2014a. Tracing Neoproterozoic subduction in the Borborema Province (NE- Brazil): clues from $\mathrm{U}-\mathrm{Pb}$ geochronology and $\mathrm{Sr}-\mathrm{Nd}-\mathrm{Hf}-\mathrm{O}$ isotopes on granitoids and migmatites. Lithos 202-203, 167-189.

Araujo, C.E.G., Rubatto, D., Hermann, J., Cordani, G.U., Caby, R., Basei, M.A.S. 2014b. Ediacaran 2,500 km-long synchronous deep continental subduction in the West Gondwana Orogen. Nature Communications 1, 1-8.

Archanjo, C.J., Hollanda, M.H.B.M., Rodrigues, S.W., Brito Neves, B.B., 2008. Fabrics of pre- and syntectonic granite plutons and chronology of shear zones in the Eastern Borborema Province, NE Brazil. Journal of Structural Geology 30, 310-336.

Brito M.F.L. 2014. Metavulcânicas ácidas do Complexo Salgueiro: caracterização e comparação com aquelas do Complexo Riacho Gravatá e Grupo Cachoeirinha, Zona Transversal, Província Borborema, NE do Brasil. In: Anais do 47 Congresso Brasileiro de Geologia, Salvador-BA. 
Brito Neves, B.B., 1975. Regionalização Geotectônica Do Précambriano Nordestino (Tese de Doutorado). Universidade de São Paulo, São Paulo, p. 198.

Brito Neves, B.B., Van Schmus, W.R., Santos, E.J., Campos Neto, M.C., Kozuch, M. 1995. O Evento Cariris Velhos na Província Borborema: integração de dados, implicações e perspectivas. Revista Brasileira de Geociências 25, 279-296.

Brito Neves, B.B., Santos, E.J., Schmus, W.R.Q., 2000. Tectonic history of the Borborema Province. In: Umberto Cordani; Edson José Milani; Antonio Thomaz Filho; Diogenes de Almeida Campos (Org.). Tectonic Evolution of South America. Rio de Janeiro: 31st International Geological Congress, pp. 151-182. Special Publication.

Brito Neves, B.B., Campos Neto, M.C.C., Van Schmus, W.R., Fernandes, M.G.G., Soiza, S.L. 2001. O Terreno Alto Moxotó no leste da Paraíba (Maciço Caldas Brandão). Revista Brasileira de Geociências 31, 185-194.

Carvalho, M.J. 2005. Evolução tectônica do domínio Marancó-Poço Redondo: registro das orogêneses Cariris Velhos e Brasiliana na Faixa Sergipana, NE do Brasil. (Tese de Doutorado), Universidade Estadual de Campinas, Campinas, p. 192.

Caxito, F.A., Uhlein, A., Dantas, E.L. 2014a. The Afeição augen-gneiss suíte and the recorf of the Cariris Velhos Orogeny (1000-960 Ma) within the Riacho do Pontal fold belt, NE Brazil. Journal of South American Earth Sciences 51, 12-27.

Caxito, F.A., Ulhein, A., Stevenson, R., Ulhein, G. 2014b. Neoproterozoic oceanic crust remmants in northeast Brazil. Geology 45, 387-390.

Dantas, E.L., 1997. Geocronologia $\mathrm{U} / \mathrm{Pb}$ e $\mathrm{Sm} / \mathrm{Nd}$ de terrenos Arqueanos e Paleoproterozóicos do Maciço São José do Campestre, NE do Brasil. (Tese de Doutorado). Unesp, Rio Claro, Brasil, 206 pp.

Kozuch, M., 2003. Isotopic and trace element geochemistry of Early Neoproterozoic gneissic and metavolcanic rocks in the Cariris Velhos Orogen of the Borborema Province, Brazil, and their bearing tectonic setting ( $\mathrm{PhD}$ thesis). Kansas University, Lawrence, p. 199.

Fetter, A.H., Santos, T.J.S., Van Schmus, W.R., Hackhpacher, P.C., Brito Neves, B.B., Arthaud, M.H., Nogueira Neto, J.A., Wernick, E. 2003. Evidence for Neoproterozoic 
continental arc magmatism in the Santa Quiteria Batholith of Ceará State, NW Borborema Province, NE Brazil: implications for the assembly of West Gondwana. Gondwana Research 6, 265-273.

Gióia, S.M.C.L., Pimentel, M.M., 2000. The Sm-Nd isotopic method in the geochronology laboratory of the University of Brasília. Anais da Academia Brasileira de Ciências 72, 219-245.

Guimarães, I.P., Silva Filho, A.F., Melo, S.C., Macambira, M.B. 2005. Petrogenesis of A-type granitoids from the Pajeú-Paraíba Belt, Borborema Province, NE Brazil: constraints from geochemistry and isotopic composition. Gondwana Research 8, 347362.

Hollanda, M.H.B.M., Archanjo, C.J., Souza, L.C., Armstrong, R., Vasconcelos, P.M. 2010. Cambrian mafic to felsic magmatisn and its connections with transcurrent shear zones of the Borborema Province (NE Brazil): Implications for the late assembly of the West Gondwana. Precambrian Research 178, 1-14.

Jardim de Sá, E.F., Legrand, J.M., Hackspacher, P.C. 1981. Contraste de estilos estruturais e metamórficos na Faixa Dobrada Sergipana. Revista Brasileira de Geociências 11, p. 128-137.

Jardim de Sá, E.F. 1994. A Faixa Seridó (Província Borborema, NE do Brasil) e o seu significado geodinâmico na cadeia Brasiliana/Pan-Africana (Tese de Doutorado. Universidade de Brasília, Brasília, p. 804.

Lages, G.A., Dantas, E.L. 2016. Floresta and Bodocó Mafic-Ultramafic Complexes, western Borborema Province, Brazil: geochemical and isotope constraints for evolution of a Neoproterozoic arc environment and retro-eclogitic hosted Ti-mineralization. Precambrian Research 280, 95-119.

Lima, M.I.C., Gava, A., Fernandes, P.E.C.A., Pires, J.L., Siga Jr. 1985. O projeto ferrotitanado de Floresta. Minérios de Pernambuco/Radam Brasil. 314p.

Lima, M.V.A.G., Berrocal, J., Soares, J.E.P., Fuck, R.A. 2015. Deep seismic refraction experiment in northeast Brazil: New constraints for Borborema province evolution. Journal of South American Earth Sciences 58, 335-349. 
Medeiros, V.C. 2004. Evolução geodinâmica e condicionamento estrutural dos terrenos Piancó-Alto Brígida e Alto Pajeú, Domínio da Zona Transversal, NE do Brasil (Tese de Doutorado). Pós-graduação em Geodinâmica e Geofísica, Universidade Federal do Rio Grande do Norte, 200 p.

Neves, S.P., 2003. Proterozoic history of the Borborema Province (NE Brazil): correlations with neighboring Cratons and Pan-African belts and implications for the evolution of western Gondwana. Tectonics 22, 1031-1044.

Neves, S.P., Bruguier, O., Vauchez, A., Bosch, D., Silva, J.M.R., Mariano, G., 2006. Timing of crustal formation, deposition of supracrustal sequences and Transamazonian and Brasiliano metamorphism in eastern Borborema Province (NE Brazil): Implications for western Gondwana assembly. Precambrian Reearch. 149, 197-216.

Neves, S.P., Bruguier, O., Silva, J.M.R., Mariano, G., Da Silva Filho, A.F., Teixeira, C.M.L., 2015. From extension to shortening: dating the onset of the Brasiliano Orogeny in eastern Borborema Province (NE Brazil Journal of South American Earth Sciences $58,238-256$.

Oliveira, R.G., 2008. Arcabouço Geofísico, Isostasia e causas do magmatismo cenozóico da Província Borborema e de sua Margem Continental (NE do Brasil) (Tese de Doutorado). Universidade Federal do Rio Grande do Norte, Natal, p. 411.

Oliveira, E.P., Windley, B.F., Araújo, M.N.C. 2010. The Neoproterozoic Sergipano orogenic belt, NE Brazil: a complete plate tectonic cycle in western Gondwana. Precambrian Research 181, 64-84.

Padilha, A.L., Vitorello., Í., Pádua, M.B., Marcelo., Fuck, R.A. 2016. Deep magnetotelluric signatures of the early Neoproterozoic Cariris Velhos tectonic event within the Transversal sub-province of the Borborema Province, NE Brazil. Precambrian Research 275, 7-83.

Rodrigues, S.W.O., Brito Neves, B.B., 2008. Padrões isotópicos Sm-Nd no limite entre os Terrenos Alto Pajeú e Alto Moxotó (PB). Revista Brasileira de Geociências 38, 211 227.

Sales, A.O., Santos, E.J., Lima, E.S., Santos, L.C.M.L., Brito Neves, B.B.B. 2011. Evolução petrogenética e tectônica do Evento Cariris Velhos na região de Afogados da 
Ingazeira (PE), Terreno Alto Pageú, Província Borborema. Geologia USP - Série Científica 11, 101-121.

Santos, A.C.L., Padilha, A. L., Fuck, R. A., Pires, A. C. B., Vitorello, I.,Pádua, M. B. 2014. Deep structure of a stretched lithosphere: Magnetotelluric imaging of the southeastern Borborema province, NE Brazil. Tectonophysics 610, 39-50, 2014.

Santos, E.J. 1977. Plutonismo granítico nos arredores de Sítio dos Nunes, Pernambuco, e seu significado no contexto da granitização brasiliana no Nordeste. Revista Brasileira de Geociências 7, 58-72.

Santos, E.J., 1995. O complexo granítico Lagoa das Pedras: acresção e colisão na região de Floresta (Pernambuco), Província Borborema (PhD thesis). Instituto de Geociências da Universidade de São Paulo, São Paulo, p. 228.

Santos, E.J., 1996. Ensaio preliminar sobre terrenos e tectônica acrecion_aria na Província Borborema. In: SBG, Congresso Brasileiro de Geologia, 39o, Salvador, Proceedings, pp. 47-50.

Santos, E.J. 2001. Folha Belem do São Francisco - SC. 24-X-A: estados de Pernambuco, Alagoas e Bahia. Brasília CPRM, 84p. (Programa de Levantamentos Geológicos Básicos do Brasil.

Santos, E.J., Medeiros, V.C., 1999. Constraints from granitic plutonism on proterozoic crustal growth of the Transverse Zone, Borborema Province, NE-Brazil. Revista Brasileira de Geociências 29, 73-84.

Santos, E.J., Nutman, A.P., Brito Neves, B.B., 2004. Idades SHRIMP U-Pb do Complexo Sertânia: implicações sobre a evolução tectônica da Zona Transversal, Província Borborema. Geol. USP. Série Científica 4, 1-12.

Santos, E.J., Van Schmus,W.R., Kozuch, M., Brito Neves, B.B., 2010. The Cariris Velhos tectonic event in northeast Brazil. J. South Am. Earth Sci. 29, 61-76.

Santos, E.J., Souza Neto, J.A., Carmona, L.C.M., Armostrong, R., Santos, L.C.M.L., Mendes, L.U.S., 2013. The metacarbonate rocks of Itatuba (Paraíba): a record of sedimentary recycling in a Paleoproterozoic collision zone of the Borborema Province, NE Brazil. Precambrian Research 224, 454-471. 
Santos, R.V., Santos, E.J., Souza Neto, J.A., Carmona, L.C.M., Sial, A.N., Mancine, L.H., Santos, L.C.M.L., Nascimento, G.H., Mendes, L.U.D.S., Anastacio, E.M.F., 2012b. Isotope geochemistry of Paleoproterozoic metacarbonates from Itatuba, Borborema. Province, Northeastern Brazil: evidence of marble melting within a collisional suture. Gondwana Research 21, 1-13.

Santos, L.C.M.L., Dantas, E.L., Santos, E.J., Santos, R.V., Lima, H.M., 2015. Early to late Paleoproterozoic magmatism in NE Brazil: the Alto Moxoto Terrane and its tectonic implications for the pre-West Gondwana assembly. Journal of South American Earth Sciences.58, 188-209.

Sial, A.N., Ferreira, V.P. 2015. Magma associations in Ediacaran granitoids of the Cachoeirinha-Salgueiro and Alto Pajeú terranes, northeastern Brazil: Forty years of studies. Journal of South American Earth Sciences 66, 113-133.

Van Schmus, W.R., Brito Neves, B.B., Hackspacher, P.C., Babinski, M., 1995. U/Pb and $\mathrm{Sm} / \mathrm{Nd}$ geochronologic studies of the eastern Borborema Province, Northeast Brazil: initial conclusions. Journal of South American Earth Sciences 8, 267-288.

Van Schmus, W.R., Oliveira, E.P., Silva Filho, A.F., Toteu, F., Penaye, J., Guimarães, I.P., 2008. Proterozoic Links between the Borborema Province, NE Brazil, and the Central African Fold Belt. Geological Society, London, Special Publications 294, 6669.

Van Schmus, W.R., Kozuch, M., Brito Neves, B.B. 2011. Precambrian history of the Zona Transversal of the Borborema Province. Journal of South American Earth Sciences 31, 227-2552.

Vauchez, A., Egydio-Silva, M. 1992. Termination of a Continental-Scale-Strike-Slip Fault in partially melted crust: The West-Pernambuco Shear Zone, Northeast Brazil. Geology 20, 1007-1010.

Veronese, W.F., Ortiz, L.R.C., Gonzales, S.R., Menor, E.A., Montes, A.S.L., Marques, N.M.G., Coutinho, J.B.L. 1985. Projeto Ferro-Titanado de Floresta (PE). Minérios de Pernambuco/Radambrasil, 155p. 


\title{
3. ARTIGO CIENTÍFICO 1:
}

\section{TWO-STAGE TERRANE ASSEMBLY IN THE CENTRAL PORTION OF THE BORBOREMA PROVINCE, NE BRAZIL: INSIGHTS FROM STRUCTURAL GEOLOGY AND GEOPHYSICAL DATA.}

Lauro Cézar Montefalco de Lira Santos ${ }^{1,2, *}$; Elton Luiz Dantas ${ }^{1}$; Roberta Mary Vidotti ${ }^{1}$ Peter A. Cawood ${ }^{3}$; Edilton José dos Santos ${ }^{4}$, Reinhaddt A. Fuck ${ }^{1}$, Haroldo Monteiro $\operatorname{Lima}^{1}$

${ }^{1}$ Instituto de Geociências, Universidade de Brasília, Brazil; ${ }^{2}$ Unidade Acadêmica de Mineração e Geologia, Universidade Federal de Campina Grande, Brazil; ${ }^{3}$ Department of Earth Sciences, University of St. Andrews, UK; ${ }^{4}$ Serviço Geológico do Brasil CPRM, Brazil.

*Corresponding author. E-mail: lauromontefalco@gmail.com

\begin{abstract}
Combined geophysical and structural data of the Transversal Sub province of the Borborema Province (NE Brazil) highlights the internal structure and interrelationships between the constituent terranes. Radiometric and magnetometric maps show distinctive signatures for the Archean-Paleoproterozoic Alto Moxotó and Neoproterozoic Alto Pajeú and Pernambuco-Alagoas terranes, that corroborate with their contrasting internal tectonic evolution. Mapped radiometric and first and second order magnetic lineaments, associated with Euler deconvolution provide unequivocal correlation between geophysics and major structures. In addition to early related deformation of the Alto Moxotó Terrane, combined analysis of late transposition foliations, lineations and kinematic criteria reveal a complex structural evolution, in which we interpret on the light of accretion tectonics. According to our proposed model, the region was affected by two assembly stages. The first phase is characterized by thrust tectonics with top-tothe-south vergence, resulting in the collage of the allochtonous Alto Pajeú Terrane with the structurally underlying Archean-Paleoproterozoic Alto Moxotó Terrane during the Cariris Velhos orogeny (ca. 1000-900 Ma). The Serra de Jabitacá Shear Zone is the proposed terrane boundary, being associated with low-angle dipping collisional granitic sheets along and mafic-ultramafic rocks interpreted as ca. $1.0 \mathrm{Ga}$ ophiolite remnants. An
\end{abstract}


alternative interpretation, is that thrusting might be later and occurred in early stages of the Brasiliano orogeny (ca. 800-520 Ma). Further, later strike-slip movements, including the continental scale E-W Pernambuco Lineament, is interpreted as the result of lateral assembly between the composite Alto Pajeú-Alto Moxotó terranes and the Pernambuco-Alagoas terrane during a metamorphic peak in the Brasiliano orogeny, being subsequently followed by a later brittle stage. Such interpretations are supported by recent published geophysical data. Hence, we suggest that the Borborema Province evolution may have been submitted to accretionary processes during the assembly and deformation of terranes on the Neoproterozoic.

Key-words: Polyciclic deformation, West Gondwana, Borborema Province, Accretion tectonics.

\subsection{Introduction}

Orogenic belts develop through convergent and collisional episodes of plate interaction, resulting in sites of strong regional deformation. Despite the unique internal architecture of each orogen, they can be classified into three major end members, which are often temporally connected: accretionary, collisional and intracratonic (Cawood et al., 2009 and references therein).

Crustal accretion in orogens occur via a combination of incorporation of fragments into an accretionary complex, subcretion, obduction, or continental collision through frontal, lateral or oblique plate motions (Colpron and Nelson, 2009; Cawood et al., 2011a; Tetretault and Builter, 2012). The final result is a complex mosaic of folds, thrust faults and strike-slip shear zones formed in response to a strong component of crustal shortening. Examples include the Appalachian-Caledonian and the Himalayan chains that resulted in the closure of the Iapetus and Tethys oceans respectively, followed by a final stage of continent-continent collision. In addition, frontal subduction may be subsequently followed by major lateral displacements via strike-slip shear zones, obliterating or overprinting early deformation stages, such as in the Western North America Cordillera and Terra Australis orogens (Dickinson et al., 2004; Cawood et al., 2011b). Tectono-stratigraphic terranes are an important component of the orogenic architecture and represent fault-bounded crustal blocks with geological 
histories distinct from adjoining blocks (Coney et al., 1980). They may be grouped into three types: i) stratigraphic, ii) metamorphic and iii) disrupted (Howell 1995) and include can include exotic crustal fragments such as oceanic plateaus, seamounts and remnants of island arcs (Tetreault and Buiter, 2014).

In this paper we combine airborne geophysical data (radiometry and magnetometry) and structural analysis of part of the Alto Pajeú, Alto Moxotó and Pernambuco-Alagoas terranes of the central portion of the Borborema Province, Brazil. Our goal is to unravel the structural architecture of these domains, including the role of the major shear zones that bound and internally disrupt the terranes as well as suggest a sequence of tectonic events that they have undergone. Further, we aim to demonstrate the significance of combining geophysics and field geology to understand episodes of terrane development and assembly in the region as a model for other Precambrian polydeformed orogens. The area selected for study is ideally suited to an integrated geophysical and structural approach because it is located at the western termination of the three terranes in a semiarid region, enabling correlation of subsurface structures and rock outcrops.

\subsection{Geological Setting}

\subsubsection{Borborema Province}

The Borborema Province (NE Brazil) constitutes the northeastern portion of the Precambrian South American platform (Almeida et al., 1981). It can be traced into West Africa through Benin, Nigeria and Cameroon and is located in the central part of West Gondwana (Figure 3.1; Brito Neves 1975; Trompette, 1994; Van Schmus et al., 2008).

The province comprises an area of approximately $400,000 \mathrm{~km}^{2}$ and is bounded to the south by the São Francisco Craton, to the west by the Parnaíba Basin, and to the north and east by marginal basins. It comprises highly deformed and frequently migmatised Paleoproterozoic terranes, locally including Archean fragments (Brito Neves et al., 2000; Santos et al., 2000; Fetter et al., 2000; Arthaud et a., 2008; Van Schmus et al., 2008; Dantas et al., 2013; Costa et al., 2015). Such terranes are interleaved with early to late Neoproterozoic terranes/domains, forming mobile belts with widespread metavolcanosedimentary (mostly metapelitic) sequences (Brito Neves 
et al., 2000; Van Schmus et al., 2003; Hollanda et al., 2015) and remnants of Ediacaran continental magmatic arcs containing granites (Santos and Medeiros, 1999; Fetter et al., 2003; Araújo et al., 2014, Brito Neves et al., 2014). In addition, it is structurally complex, being characterized by a network of shear zones up to several kilometers-wide (Vauchez et al., 1995; Archanjo et al., 2008; Oliveira, 2008; Cordani et al., 2013; Viegas et al., 2014).

It is divided into the Northern, Transversal (or Central) and Southern Sub provinces (Van Schmus et al., 1995, 2011; Santos and Medeiros, 1999; Brito Neves et al., 2000). It has been suggested that the province underwent a polycyclic Neoproterozoic history of accretion and collision-related events resulting in a complex mosaic of tectonostratigraphic terranes (Santos and Medeiros, 1999; Santos et al., 2000; 2010; Brito Neves et al., 2014; Santos et al., 2015b). Similar tectonic features have been described in the African counterpart of the province, along the Trans-Saharan belt between the Hoggar Shield and Benin-Nigerian Province (Black et al., 1994; 2003). An alternative model, argues that the province corresponds to an intracontinental orogen consolidated in response to Neoproterozoic far-field stresses (Neves, 2015).

The Northern Sub province is divided into composite terranes surrounded by supracrustal rocks as well as magmatic arcs containing Archean to Neoproterozoic lithotectonic successions. The Transversal Sub province is divided into five terranes: São José do Caiano, Piancó-Alto Brígida, Alto Pajeú, Alto Moxotó and Rio Capibaribe. The Southern Sub province contains the Meso-Neorproterozoic Pernambuco-Alagoas Terrane, as well as Neoproterozoic mobile belts that surrounds the São Francisco Craton (Santos 1996; Santos and Medeiros, 1999; Santos et al., 2000; Oliveira, 2008; Brito Neves et al., 2014). This paper focuses on the character of, and interrelationship between, the Alto Pajeú, Alto Moxotó, and Pernambuco-Alagoas terranes in the Airi region, Pernambuco (Figure 3.2).

\subsubsection{Alto Pajeú Terrane}

The overall northeast-southwest trending Alto Pajeú Terrane is separated from the Piancó-Alto Brígida one by the NE-SW strike-slip Serra do Caboclo sinistral shear zone, and from the Alto Moxotó Terrane by the ill defined Serra de Jabitacá thrust 
system (Santos and Medeiros, 1999). The terrane is interpreted as the development of a short-lived ( $<100 \mathrm{My}$ ) magmatic arc that were active during the Early Neoproterozoic, being the type area of the Cariris Velhos orogeny (ca. 1.0-0.96 Ga, Kozuch, 2003; Santos et al., 2010; Lages and Dantas, 2016 and references therein). Such event, was firstly described by Santos, (1995) and Brito Neves et al., (1995) and resulted in the intrusion of numerous calc-alkaline and peraluminous Tonian granites with arc-related to syn-collisional geochemical signature, as well as the deposition of mature and immature pelitic metasedimentary and metavolcanoclastic rocks of the São Caetano Complex, that reached the lower amphibolite facies and are associated to a back-arc setting (Figure 3.2; Santos et al., 2010 and references therein). The recent discovery of arc-related plutonism, metamafic rocks and metaultramafic rocks, including remnants of ophiolites (Serrote das Pedras Pretas Suite; Santos, 1995; Lages and Dantas, 2016 and references therein) and deep-arc roots has also confirmed the nature and extension of the Cariris Velhos event in other parts of the province (Carvalho, 2005; Oliveira et al., 2010; Caxito et al., 2014a; Lages and Dantas, 2016).

Such Early Neoproterozoic associations were significantly affected by Brasiliano-related tectono-thermal events (ca. 0.8-0.5 Ga), masking them and obliterating its structural fabric. In addition, younger Ediacaran granites are widespread and cross-cut the main supracrustal associations of the Cariris Velhos orogen, including the Serra do Arapuá, Riacho do Icó, and Quixaba plutons (Santos, 1995; Santos and Medeiros, 1999). One of the main features of this terrane is the almost absence of Paleoproterozoic crust, which is abundant in the adjoining Alto Moxotó Terrane.

\subsubsection{Alto Moxotó Terrane}

The Alto Moxotó Terrane corresponds to an old high-grade metamorphic crustal block composed of orthogneisses, migmatites and metagranites (Floresta Suite), maficultramafic rocks (Malhada Vermelha or Carmo Suites) and supracrustal sequences (Sertânia Complex) that experienced accretion and collision events between ca. 2.4 to 2.0 Ga (Figure 3.2; Brito Neves et al., 1995; Santos et al., 2004; Santos et al., 2015a). It correspond to a quasi-rigid block, presenting an unique geophysical signature, which is completely different from the adjoining terranes, including gravity and magnetic characteristics (Oliveira, 2008; Padilha et al., 2016 and references therein). According 
to Neves et al., (2015), a major metamorphic peak is marked at ca. $1.9 \mathrm{Ga}$, which is attributed by some authors as the record of a major eclogite to granulite facies event (Santos et al., 2015a and references therein). Its boundary with the Southern Sub province is the E-W continental scale dextral strike-slip Pernambuco Lineament (Brito Neves et al., 2000; Santos et al., 2000).

In addition, Santos et al., (2016, in revision) have recently documented Neoarchean TTG rocks (Riacho das Lajes Suite) in the inner portion of the terrane, which are unique within the Transversal Sub province. Furthermore, the terrane lacks evidence for the Cariris Velhos and Brasiliano orogenies, but minor occurrences of Cambrian A-type granites are present along the margins of the terrane, and have been correlated with the final magmatic pulse of the latter (Guimarães et al., 2005 and references therein). Such features led several authors, including Brito Neves et al., (2000) and Santos et al., (2004) to consider this domain as an exotic Paleoproterozoic fragment within the Neoproterozoic Transversal Sub Province.

\subsubsection{Pernambuco-Alagoas Terrane}

The Pernambuco-Alagoas Terrane occupies the northern portion of the Southern Sub province. Its southern limit with the Sergipano Fold Belt is defined by the Belo Monte Jeremoabo thrust Shear Zone (Brito Neves et al., 2000; Santos et al., 2000). The main geological units of the terrane ranges from ca. 1.13 to $0.96 \mathrm{Ga}$ in age and correponds to Cabrobó supracrustal sequence, which includes paragneisses, metagraywackes and calc-silicate rocks, and Belém do São Francisco Complex, composed of granitic to granodioritic banded orthogneisses and migmatites (Figure 3.2; Brito Neves, 1995; Santos, 1995; Van Schmus et al., 1995; Silva Filho et al., 2010).

The structural framework of the terrane is interpreted as the result of intense development of Brasiliano-related deformation coalescing the previous Tonian fabric. One of the most important characteristics of it is the large and widespread abundant occurrences of Ediacaran to Cambrian granitic intrusions, which are completely absent in the adjacent Alto Moxotó Terrane. These include mainly high-K calc-alkaline to shoshonitic batholiths, which has been recently grouped as Buíque-Paulo Afonso, Águas Belas-Canindé, Maribondo-Correntes and Ipojuca-Atalaia (Silva Filho et al., 
2010), as well as minor bodies like the Fortuna intrusions, which can be also interleaved by recently discovered Paleoproterozoic supracrustal sequences (Silva Filho et al., 2014). Such granitic rocks mark the development and evolution of a continental arc during the Brasiliano orogeny. Recently, local occurences of Archean rocks has been described in the westernmost portion of this terrane by Cruz et al., (2014).

\subsubsection{Nature of the proposed Terrane boundaries}

Within the Borborema Province, several shear zones are described. Some of them are of continental scale and separate major domains, including the development of large suture zones such as the Brasiliano-Kandhi structure (Araújo et al., 2014; Santos et al., 2015c). For instance the E-W trending Patos and Pernambuco dextral shear zones, divide the Northern, Central and Southern Sub provinces, which seems to record distinct tectonic evolutions (Brito Neves et al., 2000). Within the Borborema Province, Ar-Ar thermochronological and U-Pb point out that deformation along transcurrent shear zones took place between 590 and 500 Ma (Monié et al., 1997; Corsini et al., 1998; Neves et al., 2008, among others). However, there is no conclusive termochronological data concerning previous deformation, including thrust tectonics within the Transversal Sub province.

The studied terranes are ascribed to be limited by two important shear zones, which is the Serra de Jabitacá Thrust system in the north and Pernambuco Lineament in the south. The former separate rocks from the Tonian Cariris Velhos orogen (e.i. Alto Pajeú Terane) and the Paleoproterozoic Alto Moxotó Terrane (Santos, 1995; Brito Neves et al., 2000; Santos et al., 2002). In the literature, there are no consensus on the nature of this structure, being interpreted by the aforementioned authors as a migmatitic nappe with top-to-the-south tectonic vergence. It is mostly because of the difficulty to access kinematic and geometric criteria, mainly because of the strong obliteration by strike-slip shear zones along the Alto Pajeú Terrane, including the Afogados da Ingazeira and Livramento structures. In this study, a proper and pioneer description of the APT-AMT boundary, is presented.

On the other hand, the Pernambuco Shear Zone kinematics is widely known on the literature. It is an almost $700 \mathrm{~km}$ long branch of a well exposed Neoproterozoic structure that finds continuity in the Adamoua Lineament. It presents variable dextral 
shear criteria and local anatexis is the most mylonitic fabrics and is associated with the emplacement of several Ediacaran granitic plutons (in its easter branch) as well as reaches upper-amphbolite to granulite facies conditions (Davison et al., 1995). The contrasting geological evolutions on both sides of this structure, the association with calc-alkaline arc-related magmas and the described high strain conditions led some authors, including Santos, (1996); Brito Neves et al., (2000) and references therein to consider it as a major crustal boundary. Such interpretation is also supported by different geophysical potential methods (Oliveira, 2008; Santos et al., 2014; Padilha et al., 2016). On the other hand, Neves and Mariano (1999) based on mesoscopic structural observations, argue that such structure is divided in two distinct branches, consisting of high-temperature and low-temperature mylonitic belts and played a minor role on the Brasiliano assembly of the Borborema Province. 


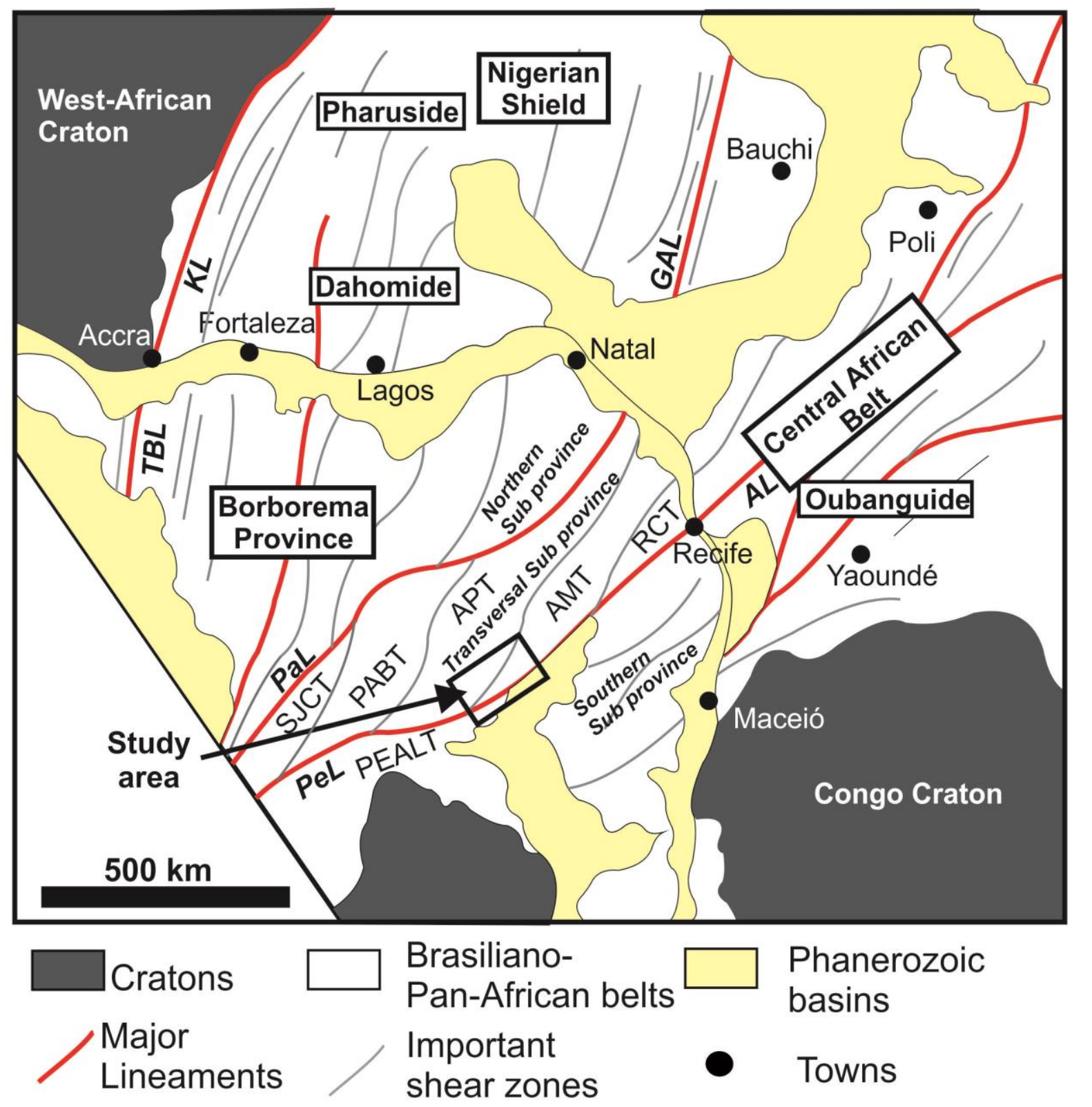

Figure 3.1 - a) Pre-drift reconstruction of Northeast South America and West Africa in West Gondwana context with the main structural provinces and lineaments on its current position. SJCT $=$ São José do Caianho Terrane, PABT = Piancó Alto-Brigída Terrane, APT $=$ Alto Pajeú Terrane, AMT $=$ Alto Moxotó Terrane, $\mathrm{RCT}=$ Rio Capibaribe Terrane, TBL = Transbrasiliano Lineament, KL - Khandi Lineament, PaL = Patos Lineament, GAL = Garoua Lineament, PeL = Pernambuco Lineament, $\mathrm{AL}=$ Adamoua Lineament. 


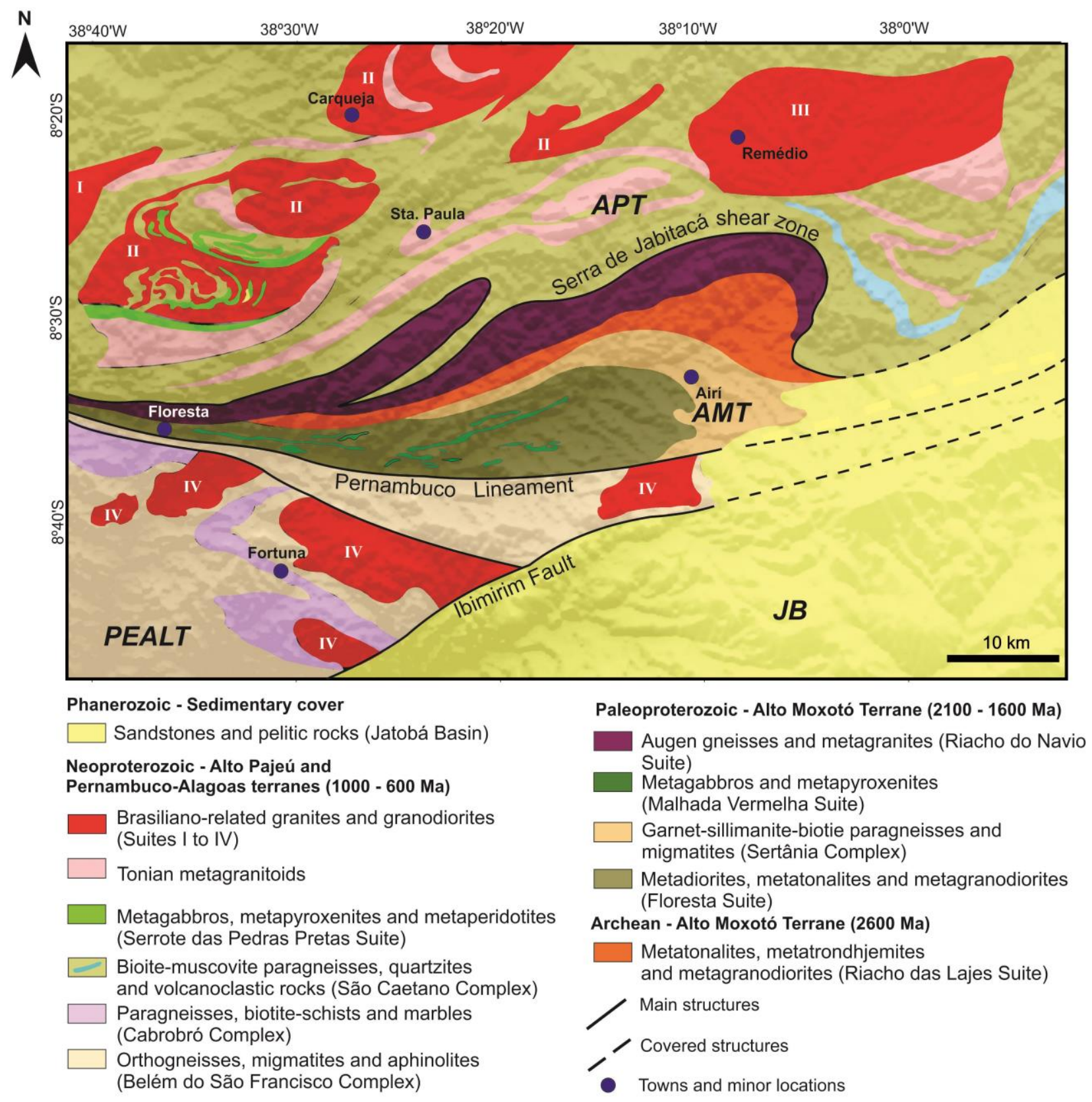

Figure 3.2 - Geological map of the study area. Ediacaran granitic suites: $I=$ Serra do Arapuá, II = Riacho do Icó, III - Quixaba, IV = Fortuna. Terranes: APT = Alto Pajeú, AMT $=$ Alto Moxotó, PEALT $=$ Pernambuco Alagoas. JB = Jatobá Basin. 


\subsection{Geophysical dataset}

Airborne radiometric and magnetometric data for the study area were obtained from the Pernambuco-Paraíba and Paraíba-Rio Grande do Norte projects undertaken by the Geological Survey of Brazil (CPRM) in 2010 that cover an area of $134.644,89 \mathrm{~km}^{2}$. These data were used to identify anomalies, delimit areas of contrasting geophysical character, and define lineaments within and between terranes (Figure 3.3).

The N-S-trending flight lines were spaced at $0.5 \mathrm{~km}$, whereas E-W tie lines were spaced at $10 \mathrm{~km}$. The nominal flight height and speed were $100 \mathrm{~m}$ and $270 \mathrm{~km} / \mathrm{h}$, respectively (LASA and Proscpectors, 2010), and sampling intervals were $1 \mathrm{~s}$ for the gamma spectrometer and $0.1 \mathrm{~s}$ for magnetometer. Geophysical data were processed with the GEOSOFT Oasis Montaj 8.0 at the University of Brasília.

Total count (TC), Th/K ratio as well as RGB ternary composition maps were created using the gamma-ray spectrometric data to delimit compositional variations across the study area (Jacques et al., 1997). For analysis of magnetic data we used the Magnetic anomaly (MA), First Vertical Derivative (DV), Total Gradient Amplitude (TGA) and Tilt Derivative (TDR). The total gradient amplitude is suitable for identification of the borders of magnetic bodies in regions of low latitude and in the presence of remanence (Li, 2006; Isles and Rankin, 2013). Tilt derivative (Miller and Singh, 1994) was applied to enhance the edges of magnetic sources related to geological contacts and structural fabric. 


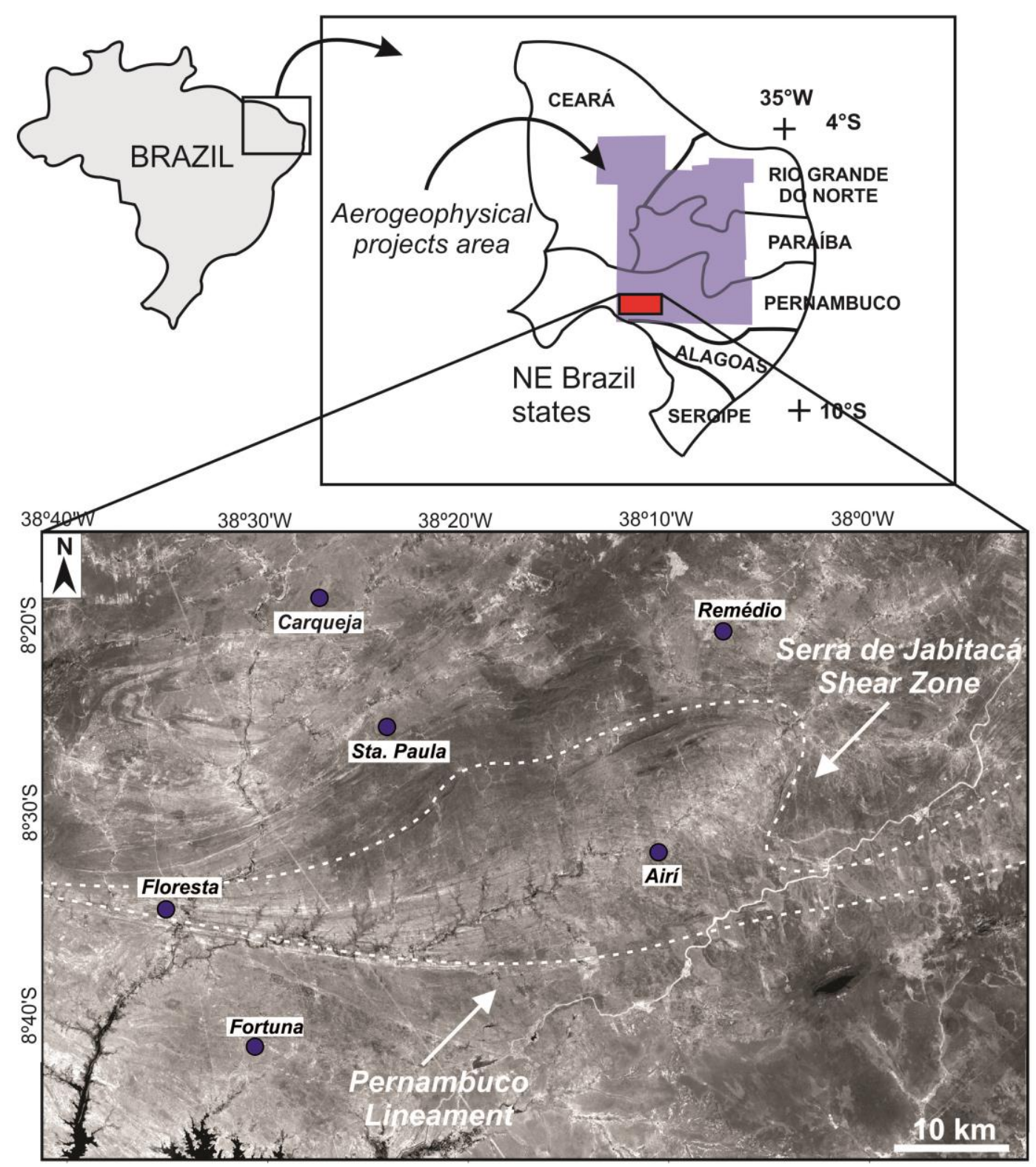

Figure 3.3 - Covered area by the Pernambuco-Paraíba and Paraíba-Rio Grande do Norte projects from Brazilian Geological Survey in NE Brazil, with a satellite image of the study area.

\subsection{Results}

\subsubsection{Gamma ray spectrometric data}

Interpretation of radiometric data was based on the distribution of the radioelements in order to define major contrasts between studied terranes. All channels $(\mathrm{K}$, eTh and eU) were used to obtain general information about the study area (not shown), but with major emphasis given to the Total Count (TC), Th/K ratio and 
composite RGB (RGB = red, green and blue; Figures 3.4 and 3.5). The TC map was used to define a total of 11 radiometric domains (A to K), which are closely associated to the major mapped geologic units (Figure 3.2). The strong correlation between radiometric and field geological data reflects the low relief and scarce vegetation cover in the study area. Major and secondary lineaments, were identified on the basis of trends in the radiometric data (Figures 3.4 and 3.5).

The Alto Pajeú Terrane comprises the majority of identified radiometric domains. Domains A and B are characterized by moderate to strong $\mathrm{K}$ values, which correspond to the Brasiliano plutonic suites; the Riacho do Icó suite has granodioritic to granitic composition, whereas Quixaba and Serra do Arapuá suites correspond to monzo- to syenogranites. Domain $\mathrm{C}$ corresponds to a northeast elongated body with slight enrichment on $\mathrm{K}$ values, and correlates with the Riacho do Forno and Recanto metagranites. Domain D is characterized by intermediate concentration of radionuclides (Figures $3.4 \mathrm{a}$ and 3.4b). This signature can be attributed to supracrustal rocks, specifically muscovite-schists and intermediate metavolcanic rocks of the São Caetano Complex (Santos, 1995). Within this terrane, Domain I corresponds to local, discontinuously, poorly mapped Phanerozoic cover, which has a very similar pattern with the Jatobá Basin in the SE portion of the study area. In addition, the gamma-ray spectometric map of the Alto Pajeú Terrane is characterized by the alternation of low and high contents of radionuclides (Figure 3.5a). The rock heterogeneity within the Alto Pajeú Terrane is reflected in values ranging from low to high on the TC map (6.9 to $28.5 \mu \mathrm{R} / \mathrm{h}$ ). Low to moderate values are attributed to supracrustal rocks of the São Caetano Complex, whereas higher values record the signature of the aforementioned Brasiliano granitoids. This correlation is consistent with the distribution of $\mathrm{eTh} / \mathrm{K}$ values (Figure 3.5c). Radiometric-defined lineaments are mostly oriented in the NE-SW direction (Figures 3.5a and 3.5b).

The Alto Moxotó Terrane presents a heterogeneous distribution of radionuclides, recorded by domains E, F, G and $\mathrm{H}$ (Figures 3.4a and 3.4b). E domain is characterized by intermediate eU and eTh compositions, and corresponds to highly deformed monzogranitic gneisses, possibly enriched in monazite. $F$ domain is represented by enrichment in eTh as compared to the other radionuclides, which is attributed to the Archean tonalitic, trondhjemitic and granodioritic rocks of the Riacho das Lages Suite. The G domain displays an intermediate distribution of $\mathrm{K}$, eTh and eU, 
and is associated with metagraywackes, paragneisses and migmatites of the Sertânia Complex. Domain. $\mathrm{H}$ domain has low values of radionuclides, around $6.9 \mu \mathrm{R} / \mathrm{h}$ (Figure 3.5a), reflecting the dioritic to granodioritic Floresta Suite as well as intercalated mafic bodies of the Malhada Vermelha Suite. The radiometric signature of domains E, F and $\mathrm{G}$ marks a progressive increase of $\mathrm{Th} / \mathrm{K}$ ratio from south to north (15.8 to $28.5 \mu \mathrm{R} / \mathrm{h}$; Figure 3.5c). Radiometric lineaments of the Alto Moxotó Terrane are intensively folded, but in the Southern portion they trend largely E-W (Figures 3.6a and 3.6c).

The Pernambuco-Alagoas Terrane is divisible into radiometric domains $\mathrm{J}$ and $\mathrm{K}$. Both domains comprise metamorphic rocks of the Belém do São Francisco Complex, however the more potassic signature of $\mathrm{K}$ domain can be related to the presence of $\mathrm{K}$ rich syenitic to alkali-feldspar granitoids of the Fortuna Suite (Figures 3.4a and 3.4b). The radiometric signature observed on the TC map (Figure 3.5a) shows an overall relatively homogeneous distribution of radionuclides, ranging from intermediate to slightly high (15.8 to $21.4 \mu \mathrm{R} / \mathrm{h}$ ). However, anomalously high values (more than 21.4 $\mu \mathrm{R} / \mathrm{h}$ ) punctuate the area and correlate with Brasiliano K-rich granites (Figure 3.5a). In addition, the eTh/K ratio map (Figure 3.5c) is characterized by very low ratio values (1.9 to 2.5). Within the Pernambuco-Alagoas Terrane, radiometric lineaments follow a NW-SE trend (Figures $3.5 b$ and 3.5d). 

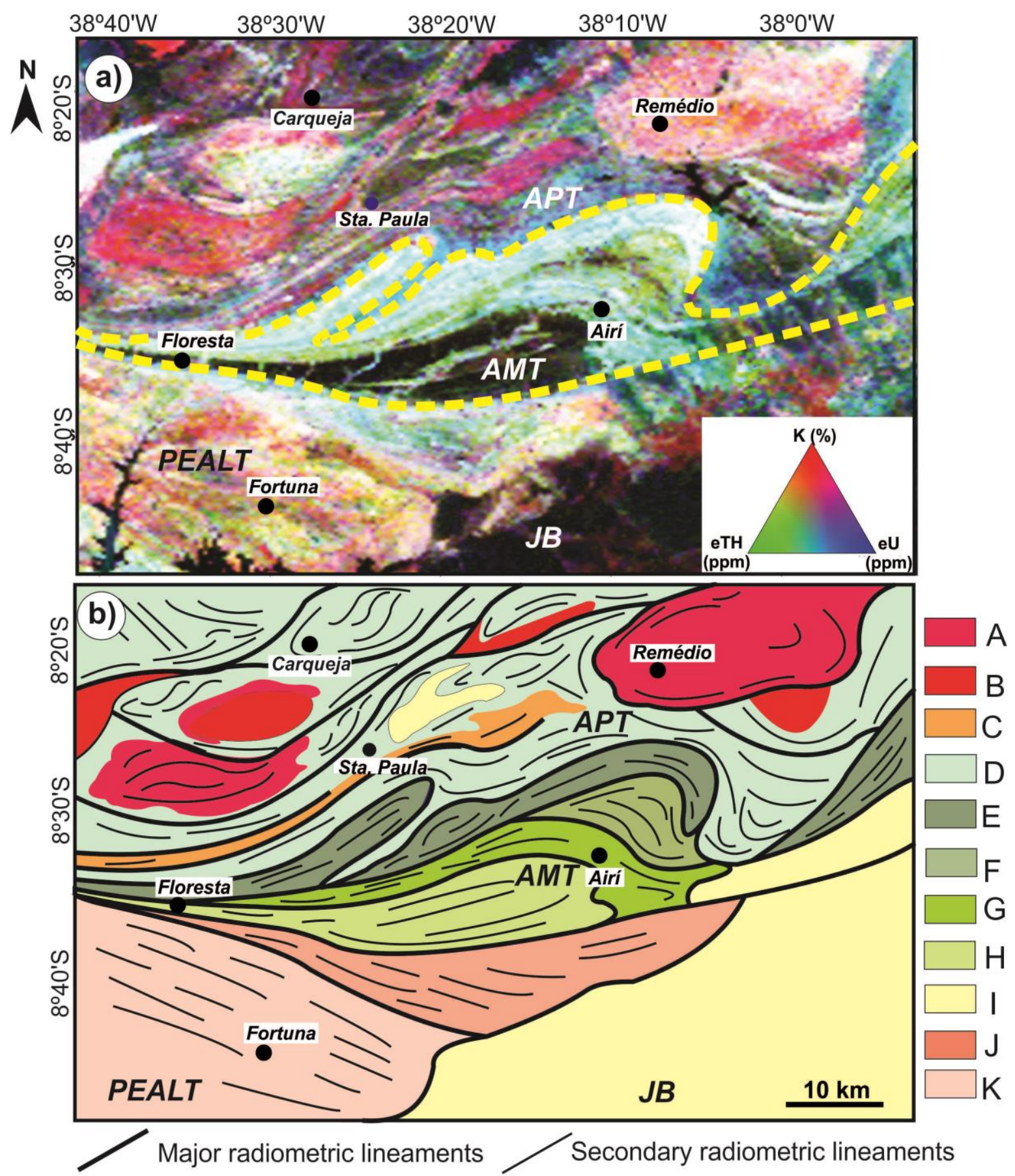

Figure 3.4 - Gamma-ray spectrometric products of the study area: a) Ternary RGB composition map; b) map of interpreted radiometric domains. Such domains are defined by contrasting signatures on the total count map. The thick yellow dashed line represent the terrane boundaries. The same is displayed to Figures 3.5 to 3.7 . 

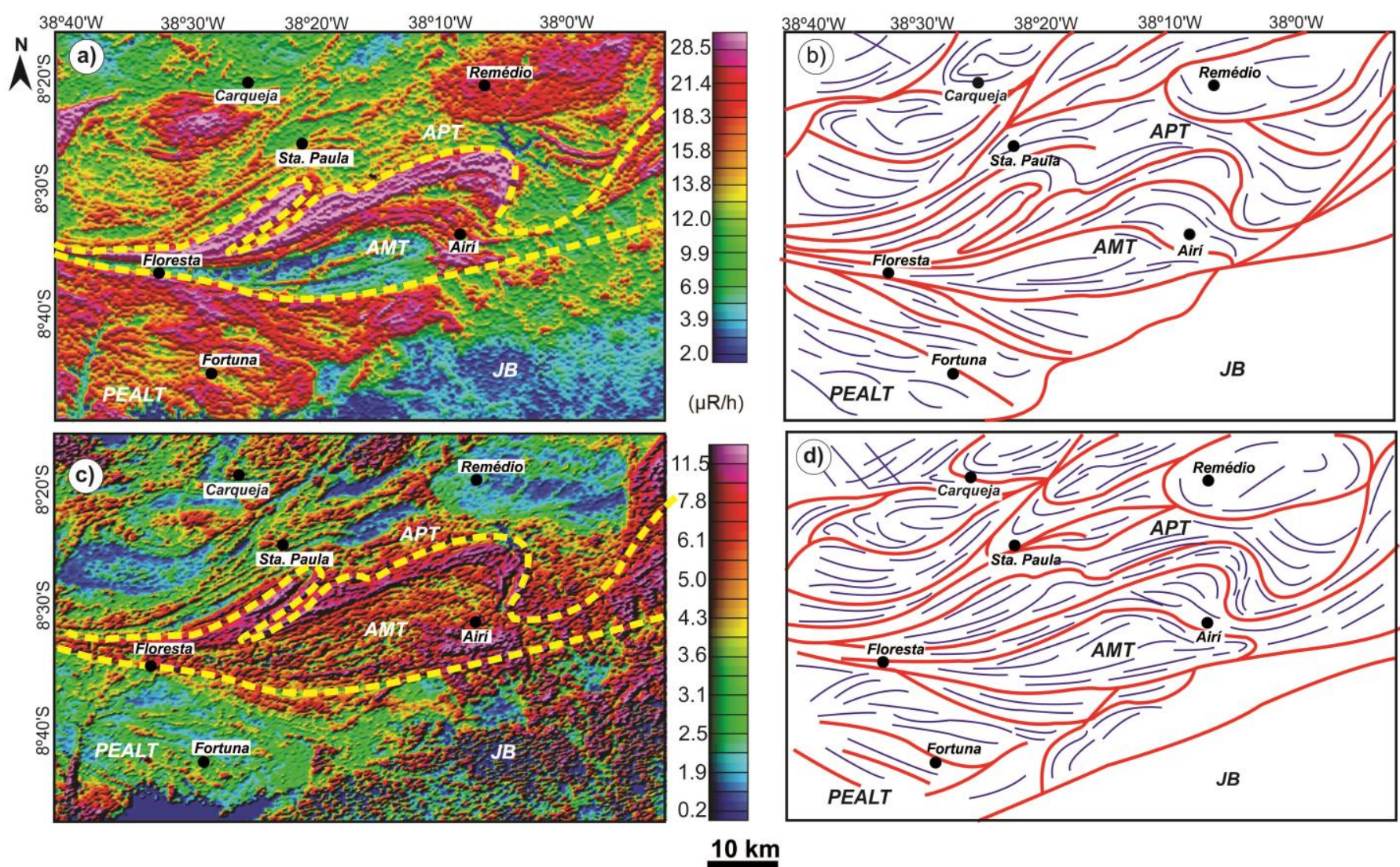

Figure 3.5 - Gamma-ray spectrometric maps as well as the main proposed terrane boundaries: a) Total count ( $\mu \mathrm{R} / \mathrm{h})$; b) Th/K ratio. c) and d) corresponds to structural interpretations of a) and b) respectively. The thick red lines represent the major radiometric lineaments, whereas the blue lines correspond to secondary lineaments. The thick yellow dashed line represent the terrane boundaries. The same is displayed to Figures 3.6 to 3.8 . 


\subsubsection{Magnetic data analysis}

Integration of magnetic anomaly and total gradient amplitude (TGA) maps (Figure 3.6) enabled delineation of the main magnetic domains. Combining these data with First derivative and Tilt derivative maps allowed recognition of major structural trends (Figure 3.7): first order lineaments include boundaries of magnetic domains whereas second order lineaments correspond to alignments within domains. Based on major variations of gradient magnetic gradient values, amplitudes, magnetic reliefs and pattern of structural lineaments, we identified eleven magnetic domains (Figure 3.8).

Domain I is characterized by irregular magnetic relief reflecting localized magnetic sources (Figure 3.6a) with associated amplitudes ranging from 0.013 to $0.0032 \mathrm{nT} / \mathrm{m}$ (Figure 3.6c). The dominant magnetic fabric trends orientated N40E, but the magnetic lineaments also show a secondary trend of E-W trend (Figures 3.6b, 3.6d, 3.7b, 3.7d and 3.8).

Domain II is located in the extreme NW of the Alto Pajeú Terrane, and is characterized by slightly irregular magnetic relief. Magnetic anomalies within the domain have overall high values and range from 16.3 to $56.9 \mathrm{nT}$ (Figure 3.6a) with intermediate to high amplitude anomalies (0.032 to 0.300 nT/m; Figure 3.6c). Second order lineaments trend N25E on average (Figures 3.6b, 3.6d, 3.7d, 3.7d and 3.8).

Domain III is characterized by very low magnetic values, ranging between 176.6 to $-75.1 \mathrm{nT}$ (Figure 3.6a). Average magnetic amplitudes are $0.300 \mathrm{nT} / \mathrm{m}$ (Figure 3.6c). Structural trends of magnetic lineaments are N65E on average) and NW-SE (S80E) on average; Figures 3.6b, 3.6d, 3.7b, 3.7d and 3.8).

The magnetic pattern of domain IV is rugged. It lies in the NE portion of the Alto Pajeú Terrane, adjacent to Domain III, differentiated from the latter by considerably high magnetic intensity (> $45.7 \mathrm{nT}$; Figure 3.6a), and high amplitude signals $(0.300 \mathrm{nT} / \mathrm{m}$; Figure 3.6c). It forms a sub-rounded shape with major second order lineaments concentrated at the margins of the domain. These magnetic structures follow a bimodal distribution, represented by E-W and N75E lineaments (Figures 3.6b, $3.6 \mathrm{~d}, 3.7 \mathrm{~b}, 3.7 \mathrm{~d}$ and 3.8$)$.

Domain V lies in the eastern portion of the Alto Pajeú Terrane, next to the limit with the Alto Moxotó Terrane. It is elongated E-W and has a curvilinear shape 
characterized by high magnetic intensity (16.3 to $38.1 \mathrm{nT}$, Figure 3.6a). On the Total gradient amplitude map, the domain is not well delineated due to the rugged magnetic relief of this portion of the area (Figure 3.6c). The main associated magnetic lineaments are N42E on average (Figures 3.6b, 3.6d, 3.7b, 3.7d and 3.8).

The Northern portion of the Alto Moxotó Terrane is occupied by domain VI, which exhibits an elongated and folded shape (Figures 3.6a and 3.6c). It is characterized by high magnetic values (16.3 - $38.9 \mathrm{nT})$ and low amplitude $(0.016-0.032 \mathrm{nT} / \mathrm{m})$. Second order associated lineaments are mostly N65E on average (Figures 3.6b, 3.6d, $3.7 \mathrm{~b}, 3.7 \mathrm{~d}$ and 3.8$)$.

Domain VII is located in the central portion of the study area. It is characterized by strongly rugged magnetic relief (Figure 3.6a), presenting mostly negative magnetic anomalies (-26.5 to $11.8 \mathrm{nT}$ ). The related amplitudes are mostly low (around 0.016 to $0.023 \mathrm{nT} / \mathrm{m}$ ), except for localized higher values (Figure 3.6c). It has a variable structural trend, due to the intense folding within the domain. In order of abundance, main trends are N35E, N75E, E-W and N-S (Figures 3.6b, 3.6d, 3.7b, 3.7d and 3.8).

Domain VIII is characterized by very low values of magnetic anomalies (around - $75.1 \mathrm{nT}$, Figure 3.6a) and high amplitudes on the TGA map (>0.153 nT/m, Figure 3.6c). Magnetic structural lineaments are mostly E-W (Figures 3.6b, 3.6d, 3.7b, 3.7d and 3.8).

Domain IX occupies the Northern portion of the Pernambuco-Alagoas Terrane, and is characterized by slightly rough magnetic relief. It presents low magnetic expression (-45.9 nT; Figure 3.6a), except for local occurrences of magnetic peaks. The TGA map reveals intermediate to high amplitude values, ranging from 0.054 to 0.153 $\mathrm{nT} / \mathrm{m}$ (Figure 3.6c). This domain is also characterized by a bimodal strike of lineaments, with one group trending E-W and the other one N45W on average (Figures 3.6b, 3.6d, $3.7 \mathrm{~b}, 3.7 \mathrm{~d}$ and 3.8$)$.

Domain $\mathrm{X}$ is mostly represented by very low magnetic intensity anomalies, ranging from -75.1 to $-26.5 \mathrm{nT}$ (Figure 3.6a), whereas associated amplitude anomalies are intermediate to high (0.032 to $0.153 \mathrm{nT} / \mathrm{m}$; Figure $3.6 \mathrm{c})$. The main magnetic structures are mostly N60W (Figures 3.6b, 3.6d, 3.7b, 3.7d and 3.8). 
Domain XI is located in the southwestern portion of the study area, and is characterized by low to intermediate values of magnetic anomalies and amplitudes that mostly range from -11.8 to $-16.3 \mathrm{nT}$ and 0.027 to $0.045 \mathrm{nT} / \mathrm{m}$, respectively. Its main magnetic structures are mostly N75W on average (Figures 3.6b, 3.6d, 3.7b, 3.7d and $3.8)$. 

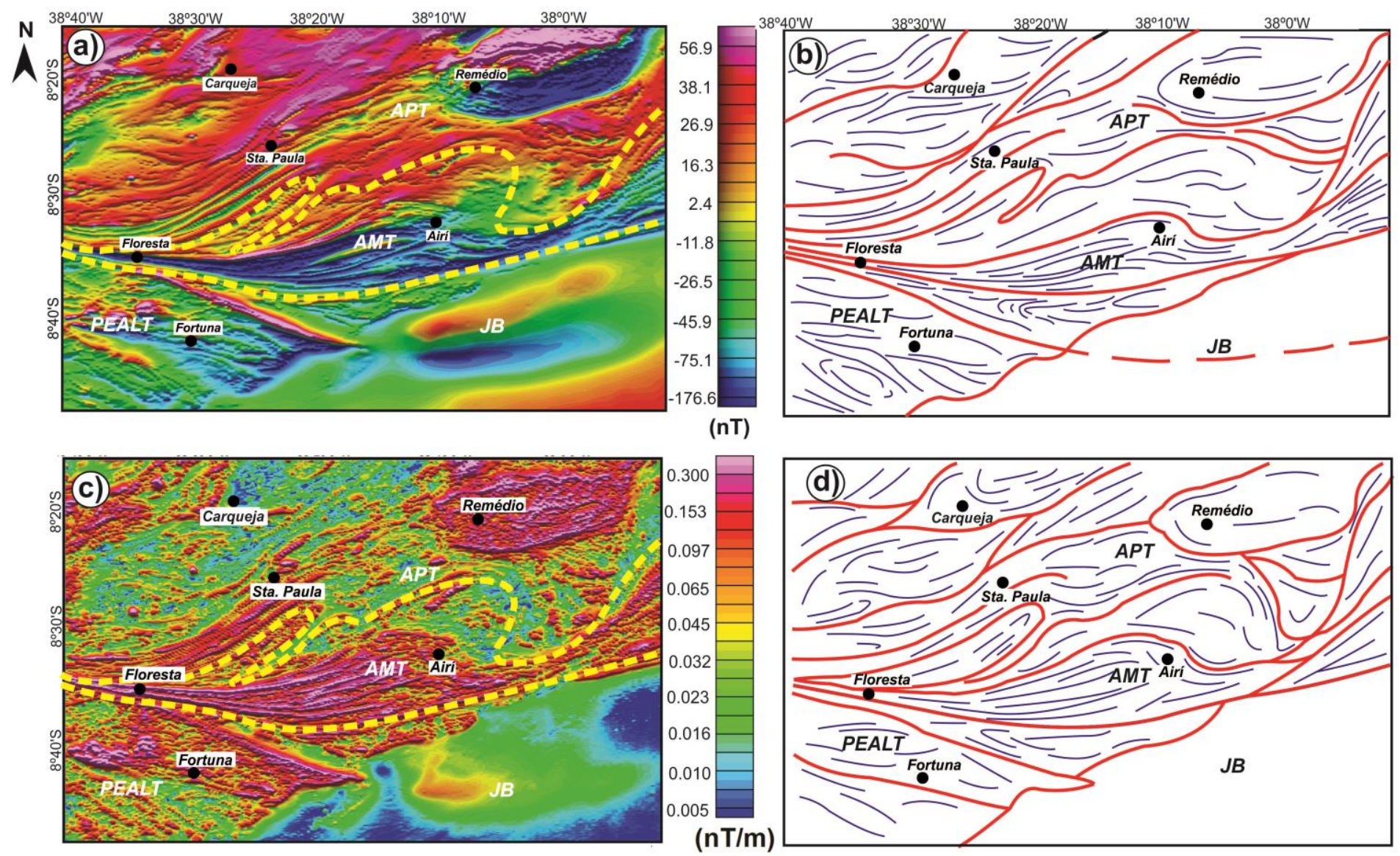

$10 \mathrm{~km}$

Figure 3.6 - Magnetic maps: a) Magnetic anomaly and b) Total Gradient Amplitude (TGA). c) and d) corresponds to structural interpretations of a) and b) respectively. 

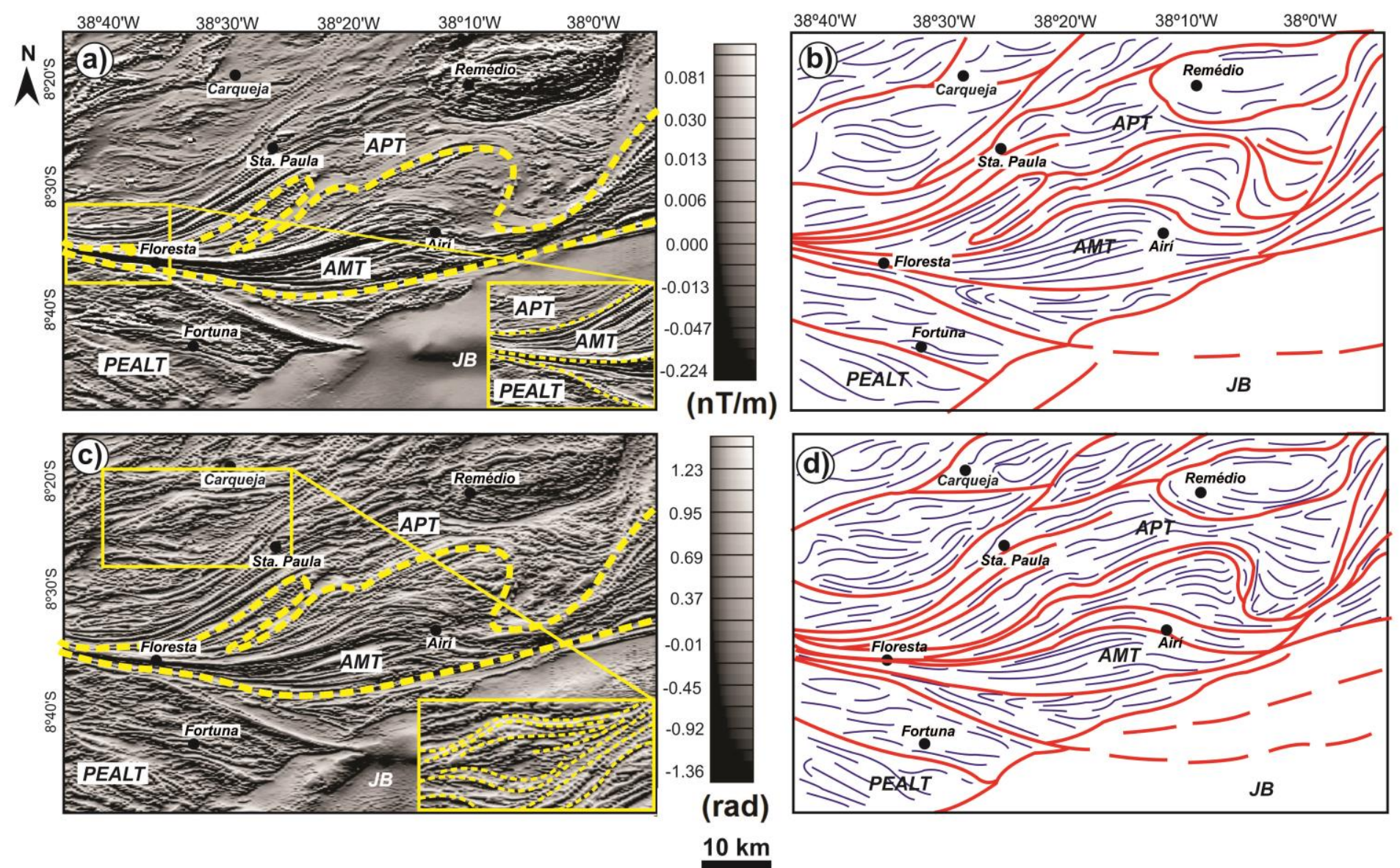

Figure 3.7 - Magnetic products: a) First vertical derivate and b) Tilt derivate maps. Note the splay termination of shear zones between the studied terranes as well as sigmoid shapes imposed by the intercalation of magnetic structures. c) and d) corresponds to structural interpretations of a) and b) respectively. 


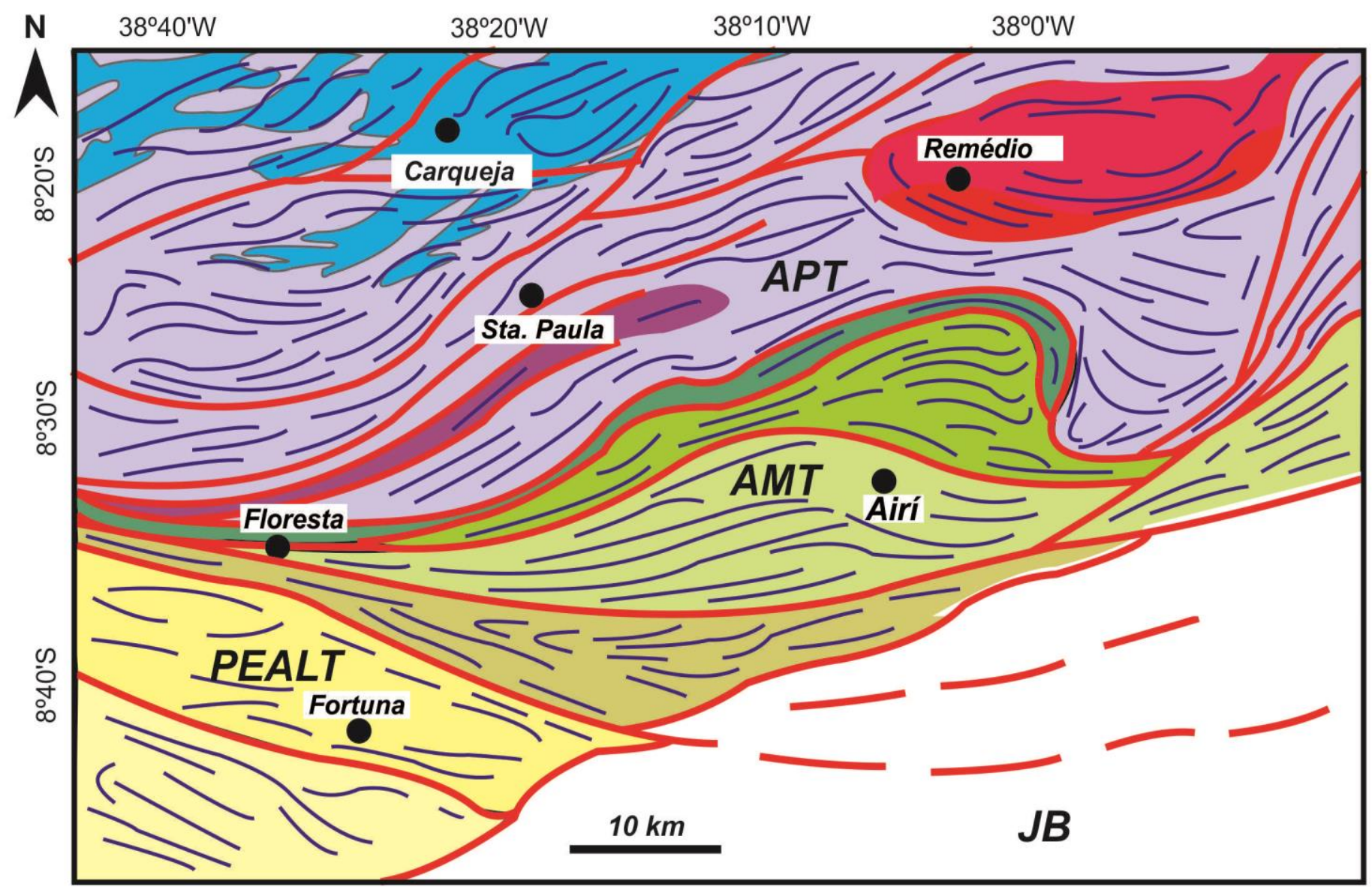

Magnetic domains

DOMAIN I

DOMAIN II

DOMAIN III

DOMAIN IV

DOMAIN V

DOMAIN VI

DOMAIN VII

DOMAIN VIII

DOMAIN IX

DOMAIN $X$

DOMAIN XI

Figure 3.8 - Interpreted magnetic domains and main magnetic lineaments of the study area. The different magnetic domains was interpreted based on magnetic intensity, relief and orientation of first order and second order lineaments. 


\subsubsection{Euler Deconvolution}

In order to obtain additional information on source position and depths to residual magnetic sources, we performed Euler deconvolution (Thompson, 1982; Reid et al., 1990). In our approach, we choose a structural index of 1 and an associated window of $1250 \mathrm{~m}$. Overall, the position of Euler solutions is in agreement with the location of the magnetic lineaments (Figure 3.6). Four main categories of depth intervals were recognized: less than $100 \mathrm{~m}$, between 100 and $300 \mathrm{~m}$, between 300 and $600 \mathrm{~m}$ and more than $600 \mathrm{~m}$ (Figure 3.9). Depths varying from 0 to $100 \mathrm{~m}$ are mainly present in the Alto Pajeú Terrane, but are also present to a lesser extent in the other terranes. Linear features ranging from 100 to $300 \mathrm{~m}$ of depth are widespread in all terranes, including the proposed terrane boundaries. Sources ranging from 300 to $600 \mathrm{~m}$ are relatively scarce, and occur mostly along major lineaments in NWSE, ENE and NESW directions in the Pernambuco-Alagoas, Alto Moxotó and Alto Pajeú terranes. Deeper solutions (> $600 \mathrm{~m}$ ) in the studied terranes are only concentrated on the NW region of the Alto Pajeú terrane and in the central portion of the Pernambuco-Alagoas terrane. In addition, deeper solutions are present along NW linear features of the Jatobá Basin.

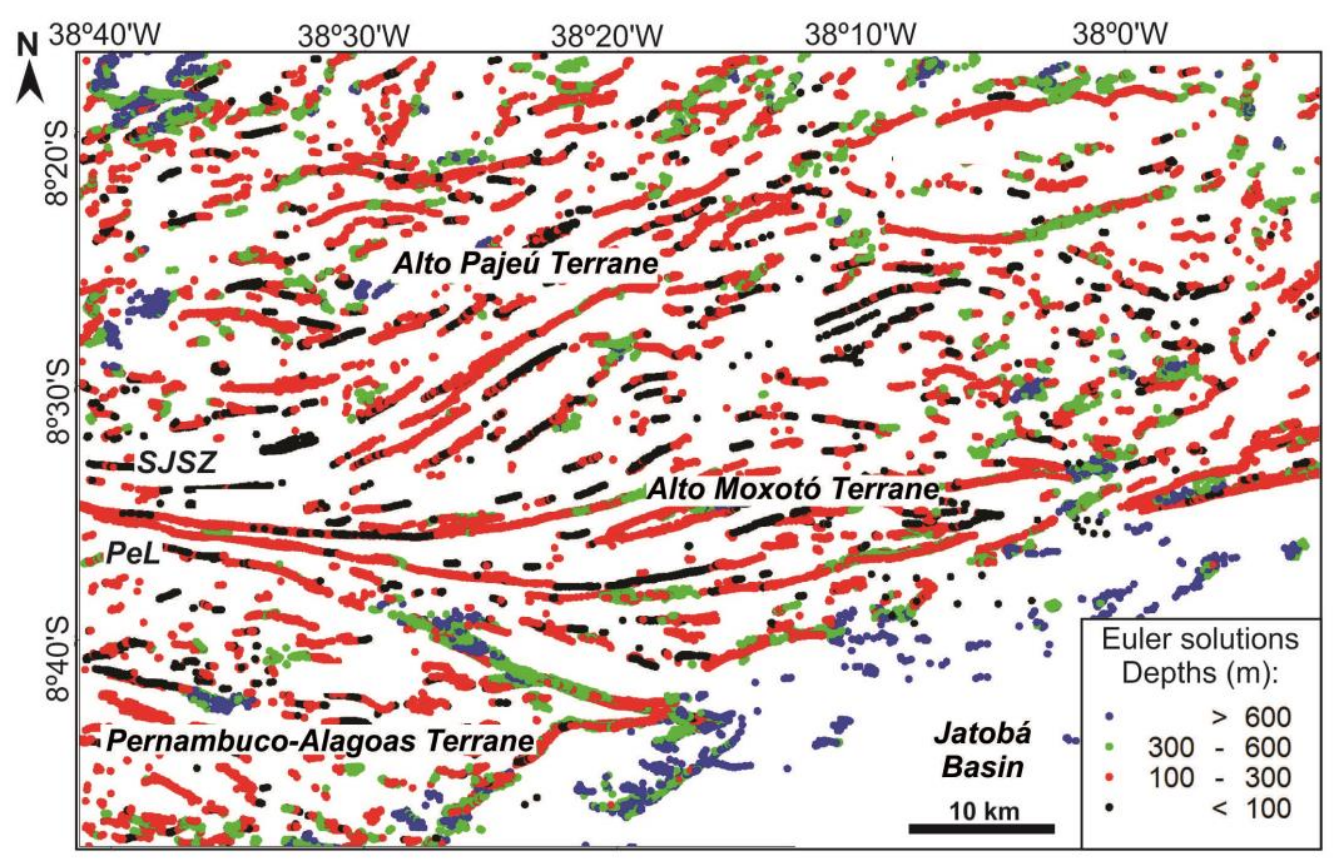

Figure 3.9 - 3D Euler deconvolution of the study area using a structural index of 1. PeL = Pernambuco Lineament, SJSZ = Serra de Jabitacá Shear zone. 


\subsubsection{Structural Analysis}

A detailed mesoscopic and microscopic structural analysis was conducted in the orthogneisses and supracrustal rocks of the study area, and was guided by lineament types delineated by geophysical interpretations. On this basis we defined three categories of lineaments (A-C). A lineaments are those that are well displayed on radiometric and magnetic maps, and are confirmed by field data. B lineaments were only identified on the magnetic products, mostly because of the Phanerozoic cover of the Jatobá Basin. C lineaments were not identified on the geophysical maps, but were observed in the field (Figure 3.10). Structural markers and overprinting relationships allowed us to define three ductile deformation stages: $D_{n}, D_{n+1}$ and $D_{n+2}$, and the brittle $D_{n+3}$. The distribution of field measurements of planar and linear fabrics as well as structural geological sections are presented in Figure 3.11. 


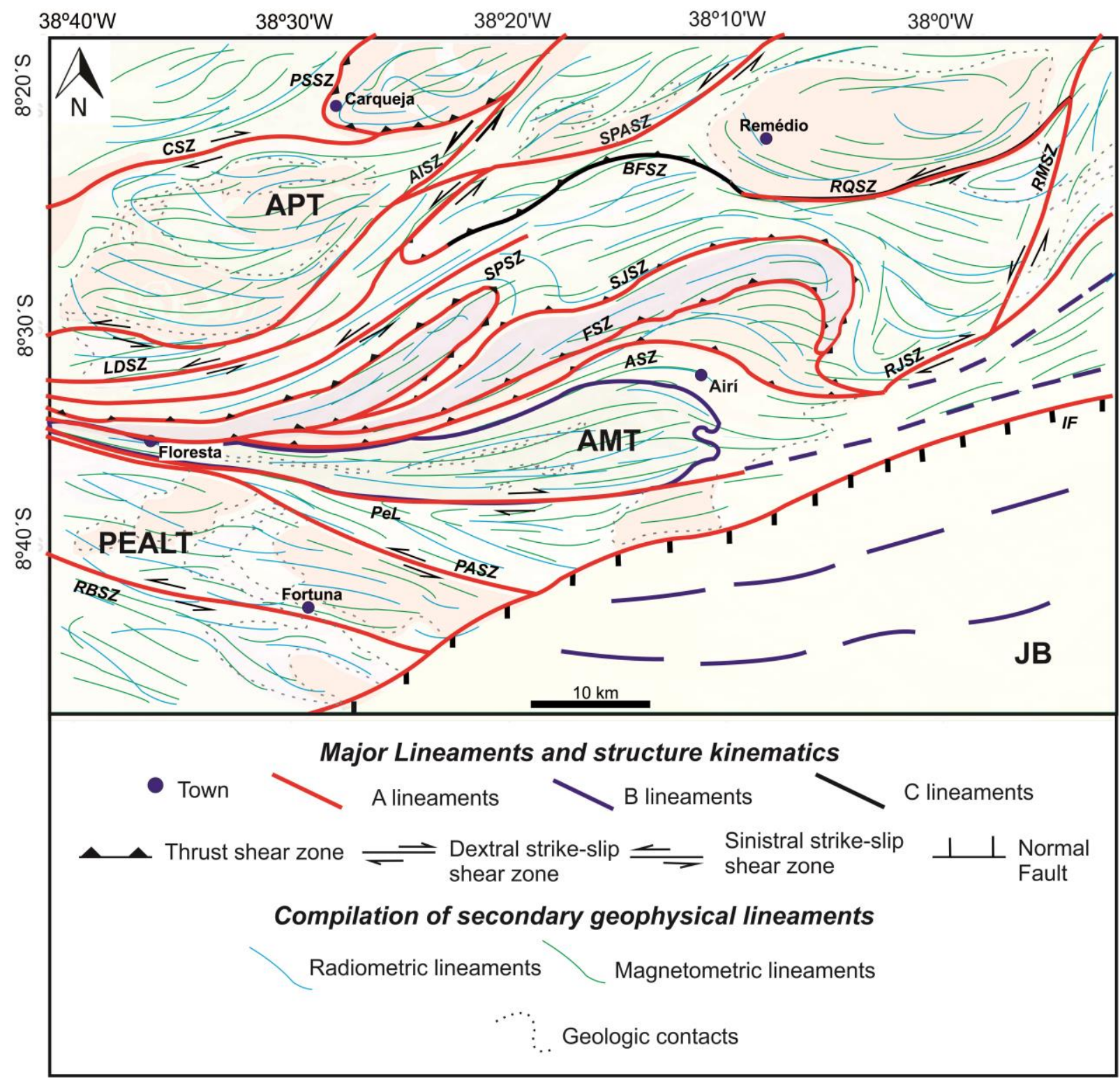

Figure 3.10 - Integrated geophysical and geological data of the main structures of the study area. PSSZ = Poço do Salgueiro shear zone; $C S Z=$ Carqueja shear zone; $A I S Z=$ Afogados da Ingazeira Shear zone; SPAZ = Santa Paula Shear Zone; LDZ = Lagoa do Defunto Shear Zone; SPSZ = São Pedro Shear Zone; BFSZ = Barra da Forquilha Shear Zone; RQ = Riacho Quixaba Shear Zone; SJSZ = Serra de Jabitacá Shear Zone; FSZ = Floresta Shear Zone; AISZ = AiríShear Zone; RJSZ = Riacho Jacaré Shear Zone; PeL = Pernambuco Lineament; PASZ = Poço da Areia Shear Zone; RBSZ = Riacho do Buraco Shear Zone; RMSZ = Riacho da Maravilha Shear Zone; IF = Ibimirim Fault. 


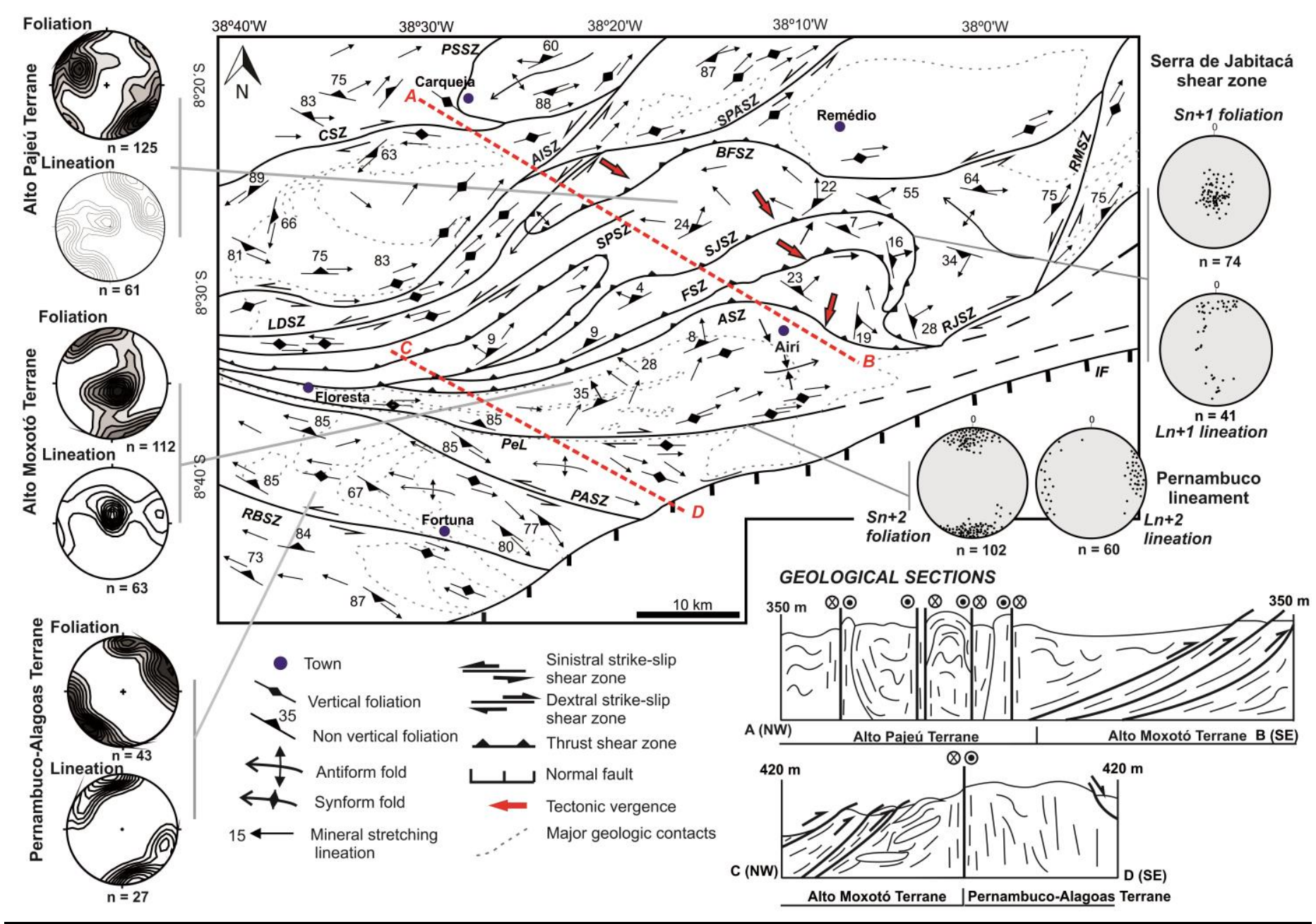

Figure 3.11 - Structural map of the study area with schematic geological sections and synthetic contour plots stereograms (lower hemisphere Schmidt projections). Names of structures are the same as in Figure 3.10. 


\subsubsection{Ductile deformation stages}

Ductile deformation is responsible for the strongly penetrative planar fabric in orthogneisses and supracrustal rocks. It is also responsible for the generation of different tectonites, which occur associated to the first and second order lineaments identified on the magnetic maps.

The $D_{n}$ deformation correspond random migmatitic fabric, restricted to the the central portion of the Alto Moxotó Terrane. The recognition of its nature as well as associated structural kinematic markers are difficult to achieve in the field, once that they seem to be partially to totally overprinted and obliterated by later structures, being present as isolated or relic fabric. It is characterized by the development of associated foliation planes $\left(\mathrm{S}_{\mathrm{n}}\right)$ found in migmatitic portions of the Riacho das Lajes Suite and Sertânia Complex. The associated metatexitic facies are frequently folded and cross-cut by vein-like structures in zones of intense in situ anatexis. The main $D_{n}$ structures are open to tight folds in stromatic veins probably during partial melting (Figure 3.12a) with hinge lines plunging in N-S, NE-SW and NW-SE directions. Schollen and raft structures are also observed (Figure 3.12b).

$\mathrm{D}_{\mathrm{n}+1}$ structures are abundant at the contact between the Alto Pajeú and Alto Moxotó terranes. They are characterized by a series of thrust surfaces that coincide with first order magnetic lineaments within the latter. The main associated rocks are protomylonites and mylonites that develop planar and plano-linear fabrics, especially in rocks of the São Caetano Complex, and tonian metagranites in the Alto Pajeú Terrane and in the Riacho do Navio, Riacho das Lajes and Floresta Suite in the Alto Moxotó Terrane. We analyzed four thrust-directed shear zones, which from north to the south are: Barra de Forquilha, Serra de Jabitacá, Floresta and Airi (Figure 3.10). These structures trend mainly NE-SW and E-W to form a major tectonic horse system. They are characterized by flat-lying to gently dipping $S_{n+1}$ foliation (Figure 3.11; Figure $3.12 \mathrm{c}$ ), which can locally form duplex structures. The foliations dip to $\mathrm{N}$ and NW and are associated with a stretching mineral lineation $\left(\mathrm{L}_{\mathrm{n}+1}\right)$ with medium to high pitch values (Figure 3.12d). However, $\mathrm{S}_{\mathrm{n}+1}$ foliation planes can be truncated or folded by later $\mathrm{S}_{\mathrm{n}+2}$ fabrics, resulting in tight to isoclinal antiforms and synforms and $\mathrm{L}_{\mathrm{n}+1}$ rotation. In addition, the $F_{n+1}$ structures form 1A and 2 fold classes (Ramsay, 1967) that have close to tight interlimb angles and include ptygmatic folds (Figure 3.13a). Alternatively, these 
latter structures might be also formed by melt injections in the host rock. Kinematic criteria that include $\mathrm{C}$ and $\mathrm{C}^{\prime}$ shear bands, highly deformed $\sigma$-type porphyroclasts of quartz and K-feldspar indicate a top-to-the-south tectonic vergence (Figure 3.13b). The most deformed tectonites show an intense recrystallization of the rock matrix and quartz grains with undulose extinction (Figure 3.13c), which in the mylonites and protomylonites include micafish (Figure 3.13d).

$\mathrm{D}_{\mathrm{n}+2}$ form the dominant structures in the study area, corresponding to the majority of the first and second order magnetic lineaments. In the Alto Pajeú Terrane, this event is represented by a complex network of NE-SW and E-W trending strike-slip shear zones. This pattern of shear zones results in the tear drop shapes of supracrustal rocks of the São Caetano Complex on the NW portion of the study area. (Figure 7c). The main related shear zones are Afogados da Ingazeira, São Pedro and Carqueja (Figure 3.11). Mesoscopic fabrics, including directional, oblique and down-dip lineations indicate suggest that the Barra da Foquilha shear zone combine elements of transcurrent and thrust stages or may represent a transpressional fabric. The main regional structure of this stage is the strike-slip dextral Pernambuco Lineament, which separates the Alto Moxotó and Pernambuco-Alagoas terranes. Planar-linear tectonites predominate in the internal part of the Pernambuco-Alagoas Terrane. They consist of local protomylonites that deform banded orthogneisses of the Belém do São Francisco Complex. The main $\mathrm{D}_{\mathrm{n}+2}$ fabrics of this terrane are recorded in the strike-slip NW-SE trending sinistral Poço da Areia and Riacho do Boi shear zones. Unlike the flat-lying $\mathrm{S}_{\mathrm{n}+1}$ foliation, the $\mathrm{S}_{\mathrm{n}+2}$ planar fabric is characterized by sub-vertical to vertical mylonites and ultra-mylonites, as well as banded orthogneisses, in response lateral simple shearing (Fig, 11; Figure 3.14a). These rocks are frequently associated with well developed subhorizontal to horizontal $\mathrm{L}_{\mathrm{n}+2}$ mineral stretching lineation (Figure 3.14b) defined by quartz $+K-$ feldspar \pm biotite aggregates. Kinematic indicators of $D_{n+2}$ include rotated asymmetric quartz-aggregates and $\sigma$ type porphyroclasts of quartz and K-feldspar, mantled quartz and feldspar $\sigma$-type sigmoids and $\mathrm{C}$ - and $\mathrm{C}^{\prime}$-types shear surfaces including mica fish (Figure 3.14c). The $\mathrm{SC}^{\prime}$ dextral fabric is mostly evident in mylonites related to the Pernambuco Lineament, which are characterized by recrystallized quartz and feldspar porphyroclast, locally embedded by an anastomosing $\mathrm{S}_{\mathrm{n}+2}$ foliation. $\mathrm{F}_{\mathrm{n}+2}$ folds are associated with the main shear zones, including open to tight and isoclinal synforms, antiforms and overturned folds with curved hinge lines. 
Oblique mineral stretching lineation (Figure 3.14d) can also be observed, suggesting $D_{n+1}$ and $D_{n+2}$ fabrics interference or an oblique movement of $D_{n+2}$. At last, in major high strain corridors associated with major shear zones such as the Pernambuco Lineament exhibit sheath folds in zones of local anatexis.

\subsubsection{Brittle deformation}

Brittle structures were only observed at a mesoscopic scale and include faults and fractures that vary in dip from horizontal to sub-vertical and vertical, and are usually discordant with regional foliation. However, some fractures are concordant with the main $S_{n+2}$ shear zones, especially close to the Pernambuco Lineament. These structures are formed of quartz veins or quartz-feldspar segregations that cross-cut main $\mathrm{L}_{\mathrm{n}+2}$ mineral stretching lineation and hinge lines of $\mathrm{S}_{\mathrm{n}+2}$ folds. Discordant structures are represented by local strike-slip faults, some of which form conjugated shear systems, that include domino-like pattern between NE-SW and NW-SE directions (Figure 3.15a). They are characterized by fault slickenside composed of recrystallized quartz, chlorite and sericite (Figure $3.15 \mathrm{~b}$ ). 


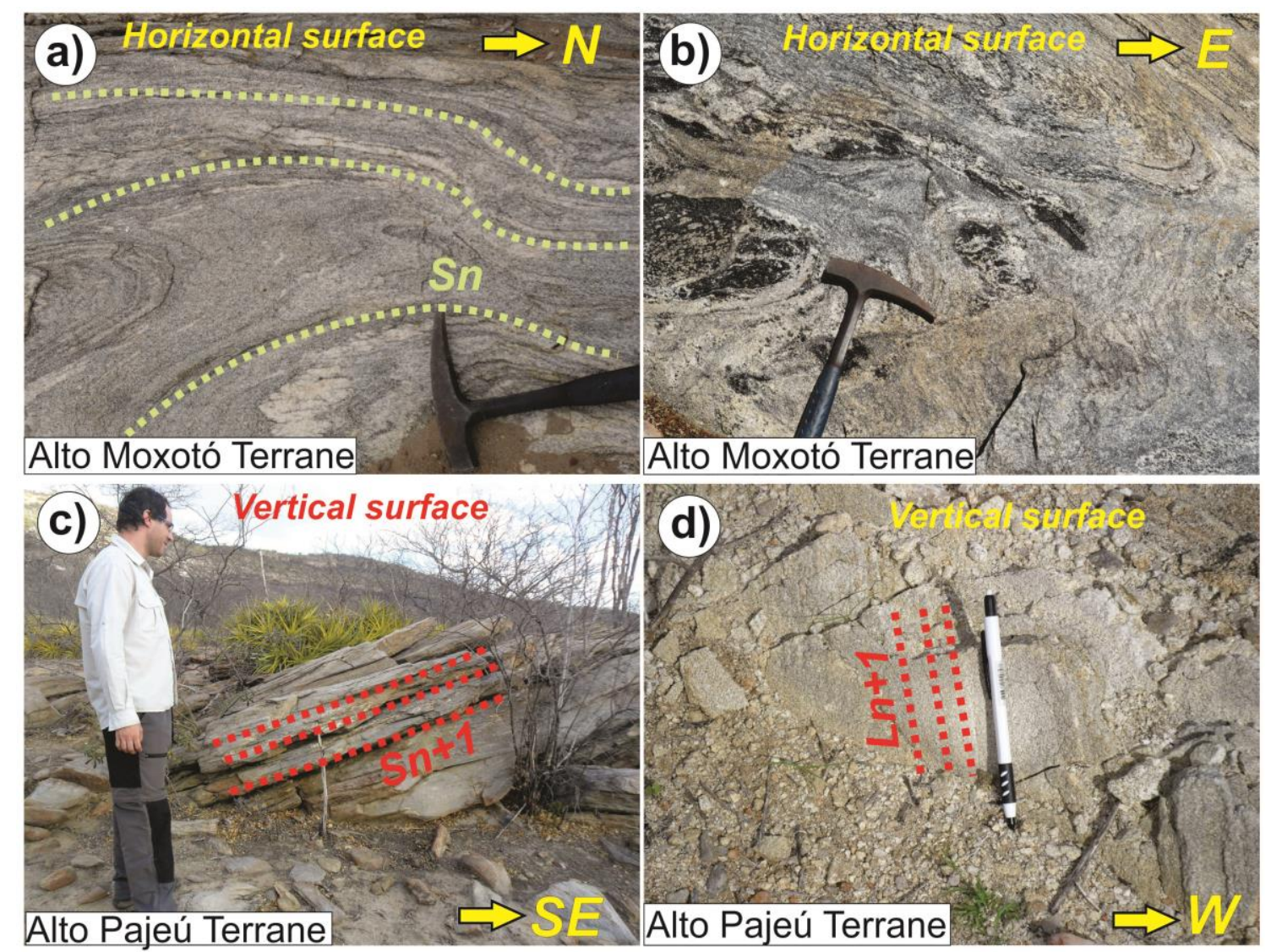

Figure 3.12 - Structural markers related to $D_{n}$ and $D_{n+1}$ phases. a) Stromatic to folded migmatite of the ca. 2.6 Ga Riacho das Lajes Suite exhibiting relict $S_{n}$ foliation (intrafolial fold) in a metatexitic facies; b) strongly mobilized diatexite of the Riacho das Lajes Suite showing schollen structure associated with mafic facies; c) gently dipping $\mathrm{S}_{\mathrm{n}+1}$ foliation in tabular sheet of Tonian metagranitoid of the Alto Pajeú Terrane; d) High pitch $\mathrm{L}_{\mathrm{n}+1}$ mineral stretching lineation on fine-grained Tonian (ca. 0.92 Ga) metagranitoid. 

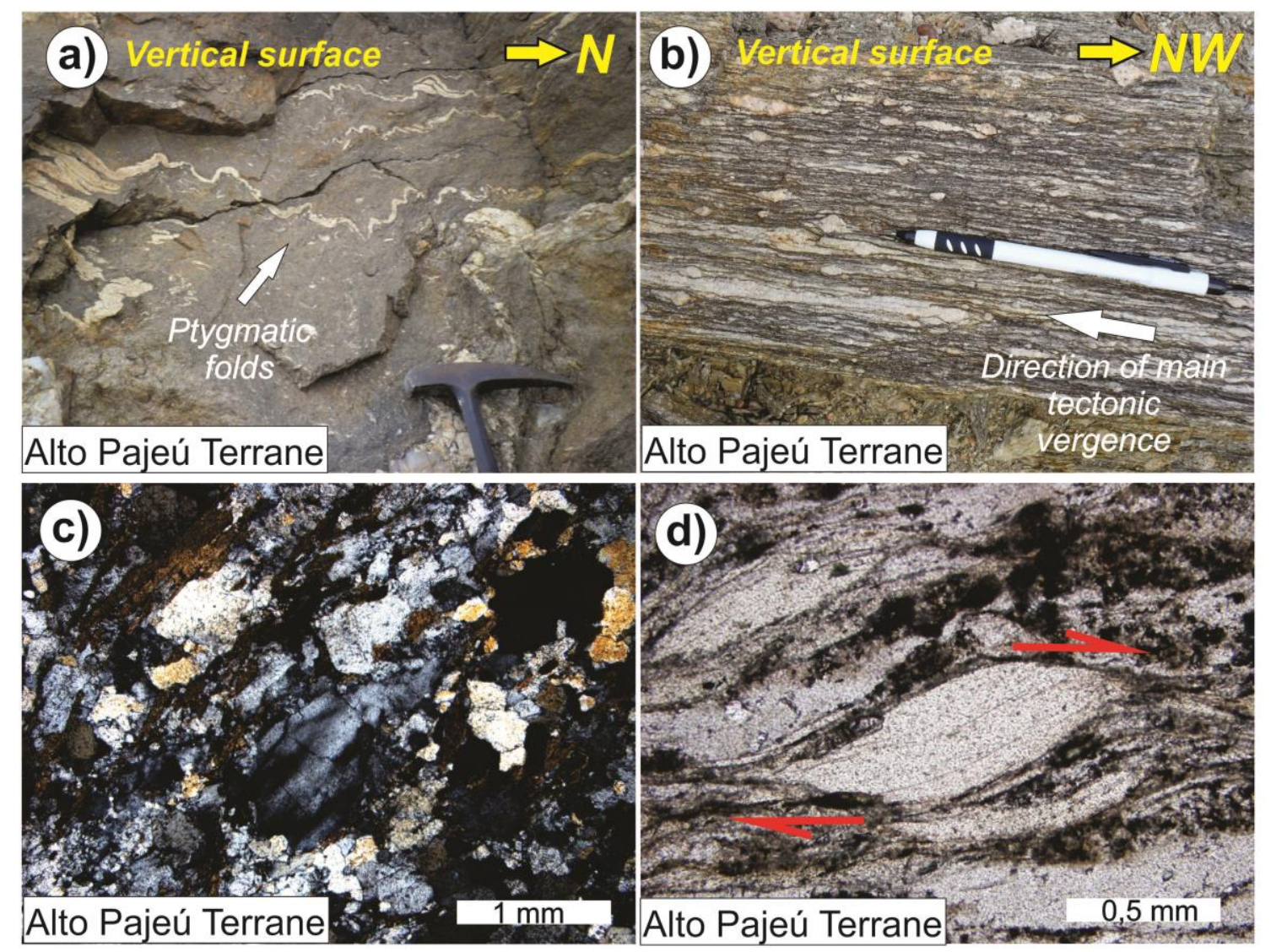

Figura 3.13 - Structural markers related to $D_{n+2}$ phase $D_{n+1}$ phases. a) $F_{n+1}$ ptygmatic folds indicating distinct competency between leucocratic and mesocratic materials; $b$ ) 8/360Az dipping $S_{n+1}$ mylonitic fabrics in a linear tectonite of the ca. $0.97 \mathrm{Ga}$ São Caetano Complex, with associated asymmetric porphyroclasts suggesting top-to-the-S thrust vergence; c) quartz ribbons with ondulose extinction in a recrystallized quartz matrix in protolylonitic rock; d) micafish developed in a mylonitic facies of the São Caetano Complex associated with the Serra de Jabitacá Shear Zone, exhibiting clockwise movement. 

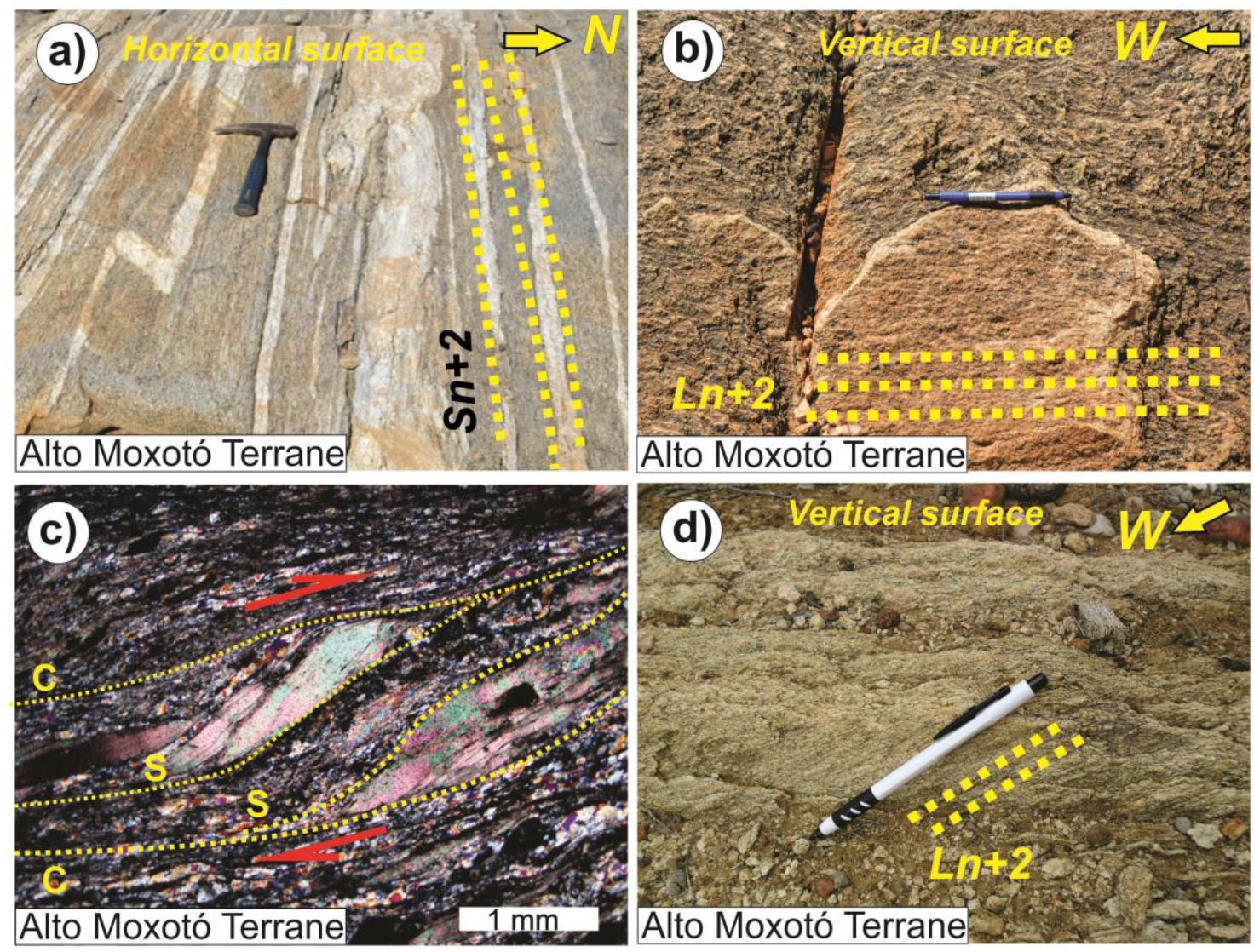

Figure 3.14 - Structural markers related to $D_{n+2}$ phase. a) Banded orthogneiss of the ca. 2.1 Ga Floresta Suite displaying deformed leuco- and mesocratic E-W bends; b) horizontal $L_{n+2}$ stretching mineral lineation associated to a vertical $S_{n+2}$ foliation plane of the Pernambuco Lineament; c) photomicrograph of granodioritic mylonite with mica fish arranged between C-type shear bands associated with the Pernambuco Lineament; d) oblique $\mathrm{L}_{\mathrm{n}+2}$ lineation in myloniticparagneiss of the ca. 2.01 Ga Sertânia Complex related to the Pernambuco Lineament. 


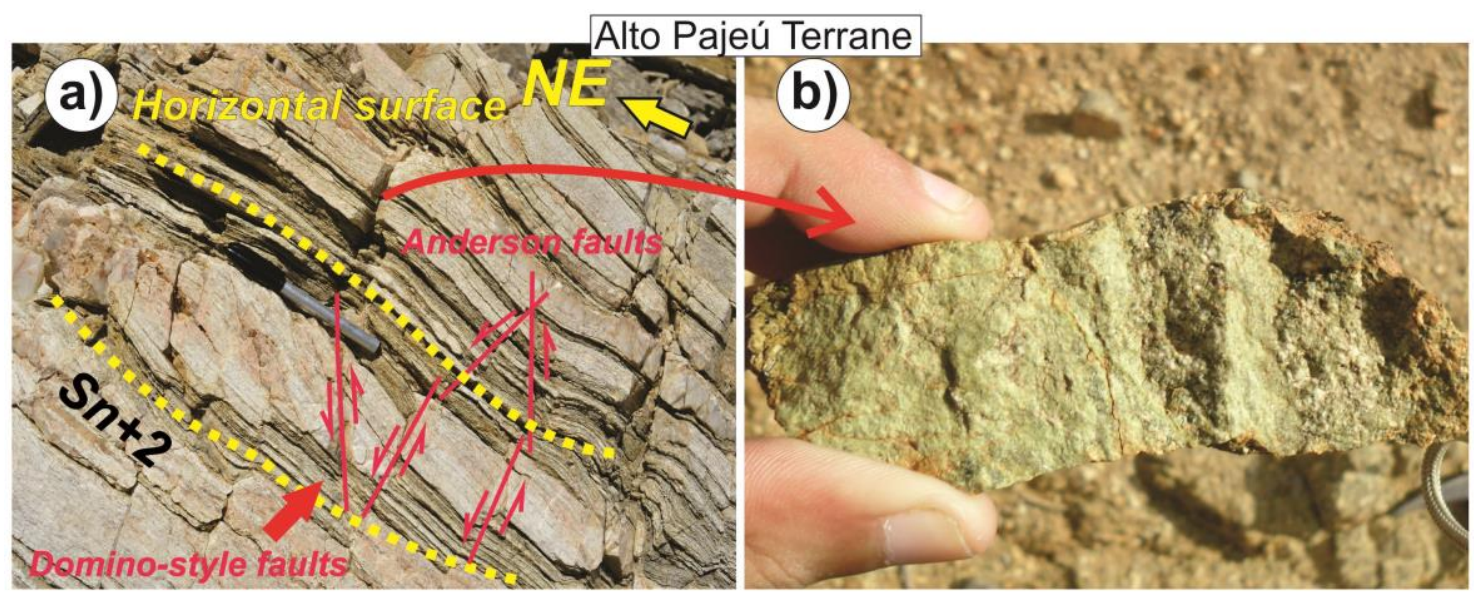

Figure 3.15 - Structural markers related to a) $D_{n+3}$ Conjugated pair of fractures forming domino-like structures of deformation cross-cutting $\mathrm{S}_{\mathrm{n}+2}$ foliation planes in paragneiss of the ca. 0.97 Ga São Caetano Complex; b) Detail of fracture plane showing neoformed mineral aggregates of quartz, chlorite and sericite.

\subsection{Discussion}

Integration of geophysical and structural data for the Alto Pajeú, Alto Moxotó and Pernambuco-Alagoas terranes of the Borborema Province constrain the structural framework and tectonic evolution of this portion of West Gondwana. Such terranes are characterized by internal contrasting tectonic evolutions. The Alto Pajeú Terrane is interpreted as a record of an Early Neoproterozoic magmatic arc that evolved during the Cariris Velhos orogeny (ca. 1.0-0.9 Ga; Brito Neves et al., 1995). It is formed by extensive Tonian supracrustal rocks and metaplutonites, including remnants of ophiolitic sequences, as well as some Ediacaran granitoids (Santos et al., 2010). In addition, it lacks of Paleoproterozoic crust. Also, the adjoining Alto Moxotó Terrane is composed by abundant Archean to Paleoproterozoic rocks, including TTG gneisses, and lacks of any evidence of the Cariris Velhos orogeny. Furthermore, it present scarce occurrence of Ediacaran granites, being considered by many authors as an exotic stable block within the Neoproterozoic Borborema Province (Santos et al., 2004; 2015 and references therein). Lastly, the Pernambuco-Alagoas Terrane is composed by some register of Paleoproterozoic and Tonian rocks, including metasedimentary and metaplutonic sequences, but is anomalously rich in intrusions of large granitic 
Ediacaran batholiths, which are interpreted as preserved remnants of the Brasilianorelated continental arc (Silva Filho et al., 2010, 2014).

Key geophysical features presented in this study, suggest that the lithotectonic associations in the area might represent fault bounded terranes that underwent subsequent amalgamation. These features include: i) distinct content of radionuclides, including Th enrichment and K-depletion in the Archean-Paleoproterozoic terrane, relative to others, which reflects the primitive nature of the principal rock units as well as the absence of Brasiliano granites (K-rich) and ii) contrasting magnetic signature between the terranes, with more magnetic rocks present in the Alto Pajeú Terrane (eg. see CMA map, Figure 3.6a), whereas the Alto Moxotó Terrane, for instance, is characterized by very low magnetic anomalies. Such signature may be interpreted as the presence of Tonian Fe-Ti ore occurrences, which are exclusive from the former (Santos, 1995; Lages and Dantas, 2016). In addition, abundant interpreted radiometric and magnetic first and second order structures correlate with major ductile shear zones, whereas Euler deconvolution constrains the position and geometry of the top of the main magnetic anomalies, including the proposed terrane boundaries.

Additional geometric and kinematic analyses enable the recognition of a polyphase deformation history that can be associated to the timing of terrane assembly. In spite of the early folded foliations and migmatitic structures recognized in the inner portions of the Alto Moxotó Terrane, thrust and transcurrent tectonics are widespread. The associated thrust shear zones strongly overprint and obliterate the internal early framework of the this terrane and the thrust Serra de Jabitacá Shear Zone is interpreted as a possible boundary between the Alto Pajeú and Alto Moxotó terranes. Mapped thrust-related elements are interpreted as the result of the transported allochthonous character of the Alto Pajeú Terrane with respect to the Alto Moxotó Terrane. Hence, we suggest that, that such terrane collage took place about 1000-920 Ma during the Cariris Velhos orogeny (Figure 3.16a). The main reasons for this interpretation include: i) mapped tectonic sheets of Tonian low-angle dipping metagranites and mylonites with top-to-the-south tectonic vergence, which has unequivocal geochemical signature compatible with magmatic arc to collision-related settings (Santos, 1995; Santos et al., 2010), ii) the existence of dioritic-granitic dykes in the Northern portion of the Alto Pajeú Terrane that cross-cut similar thrust-related Tonian rocks, known as Minador Suite, being interpreted as pre-Brasiliano (Sales et al., 2011), thus, marking a pre- 
strike-slip and post thrusting extensional stage and iii) the lack of thrust-related top-tothe-south structural markers in the Ediacaran granites. In addition, Tonian units of the Alto Pajeú Terrane such as the ca 1.0 Ga Serrote das Pedras Pretas Suite, which is spatially associated to thrusting, including the terrane boundary, are unequivocally related to convergent setting, being interpreted as a relic of the Cariris Velhos oceanic crust (Santos, 1995; Brito Neves et al., 2005; Santos et al., 2010; Lages and Dantas, 2016). Furthermore, we suggest that a frontal/oblique accretion resulted in a major basement-core nappe structure consistent with thick-skinned tectonics similar to the accretion of island arcs and other continental fragments towards the Eurasian margin (Hall, 2009; Pubellier and Meresse, 2013). However, an alternative possibility for thrusting age, is that it might be related to the Brasiliano orogeny. In such case, it should be developed before granitoid intrusion and followed by strike-slip tectonics, being part of a single orogenic stage as suggested by Neves et al., (2005 and references therein) in other parts of the Province. We believe that future works should expand on this topic to clearly elucidate this issue.

On the other hand, strike-slip tectonics is widespread in the Province and related structures are well exposed in the Transveral Sub Province. In the study region, it is mainly represented by the Pernambuco Lineament, a major high-angle regional structure that divides the Alto Moxotó and Pernambuco-Alagoas terranes (Brito Neves et al., 2000). Such structure consist mainly of mylonites with up to several kilometers wide, which in its eastern branch is associated with several syn-tectonic granite emplacements (Vaucher, 1995; Weingerg et al., 2004). Associated NE-SW and NW-SE structures are also present in the inner portions of the Alto Pajeú and PernambucoAlagoas terranes, respectively. However, the timing of assembly terranes via the Pernambuco Lineament (eg. Alto Moxotó and Pernambuco-Alagoas) is poorly constrained, but overall strike-slip movements in the Borborema Province are related to a metamorphic peak around ca. 590-560 Ma, during the Neoproterozoic Brasiliano Orogeny (Vauchez and Egydio-Silva, 1992; Santos and Medeiros, 1999; Archanjo et al., 2008; Brito Neves et al., 2014; Viegas et al., 2016), which is a fair estimation. Lastly, brittle tectonics is interpreted as post-terrane assembly. The development of strike-slip shear zones and faults is interpreted in many sunbduction-related orogens as a result of increasing of convergence obliquity (Jarrard et al., 1986), accompanying subsequent crustal reworking (Tozer et al., 2002; Cawood et al., 2009; Tetrault et al., 2012). 
Our analysis of the Airi area in the Borborema Province is consistent with the reported geometries documented in other accretionary orogens (Kusky and Bradley, 1999; Collins, 2002), which report initial thrust structures associated with terrane assembly followed by transcurrent movements, which, in NE Brazil, we relate to the Cariris Velhos and Brasiliano orogenies, respectively (Figure 3.16). For instance, late strike-slip shear zones in the Altai orogen of the Central Asian Fold Belt are interpreted the result of lateral terrane collage during the Paleozoic, strongly obliterating early accretionary structural markers (Bulsov et al., 2004 and references therein). In addition, the Uralian orogen records a protracted orogenic history involving frontal crustal accretion as well as coeval strike-slip terrane displacement (Puchkov, 2009 and references therein). Such polyciclic evolution in the Transversal Sub Province is also supported by recent magnetotelluric investigation of Padilha et al., (2016), which suggest that the Cariris Velhos orogeny represent an important accretion marker on the Borborema Province evolution. Nevertheless, we understand that rotation of the stress field via strain partioning is an alternative possibility, as it is a common feature of monocyclic orogens (eg. Northrup and Burchfiel, 1996). Such a model has been suggested by Neves et al., (2005) for the genesis of oblique lineations in orthogneisses and metasedimentary rocks throughout the Transversal Sub province and corroborate with the intracontinental hypothesis (Neves, 2015).

Recent geophysical investigations performed in other parts of the Province, have demonstrated the role of major regional structures as limiting contrasting crustal blocks (eg. Santos et al., 2014; Correia et al., 2015; Lima et al., 2015; Padilha et al., 2016). These data associated with additional petrological evidence such as the significance of Ediacaran preserved ophiolitic sequences (Oliveira et al., 2010; Caxito et al., 2014b) as well as Tonian and Ediacaran continental arc-related granites (Santos et al., 2010; Brito Neves et al., 2016) and high-pressure to ultra-high-pressure rocks i (Santos et al., 2009; Santos et al., 2015c), along with suture zones mapped in the African counterpart of the province (Black et al., 1994, Caby et al., 2003) also point out that terrane accretion played an important role on this portion of West Gondwana. Lastly, The contrasting geophysical signature, rock association and available ages between the studied terranes, in addition to important regional structures is interpreted as common features of well known accretionary orogens worldwide (Howell, 1995; Pfiffiner, 2006; Cawood et al., 2009; Stern and Scholl, 2010). 


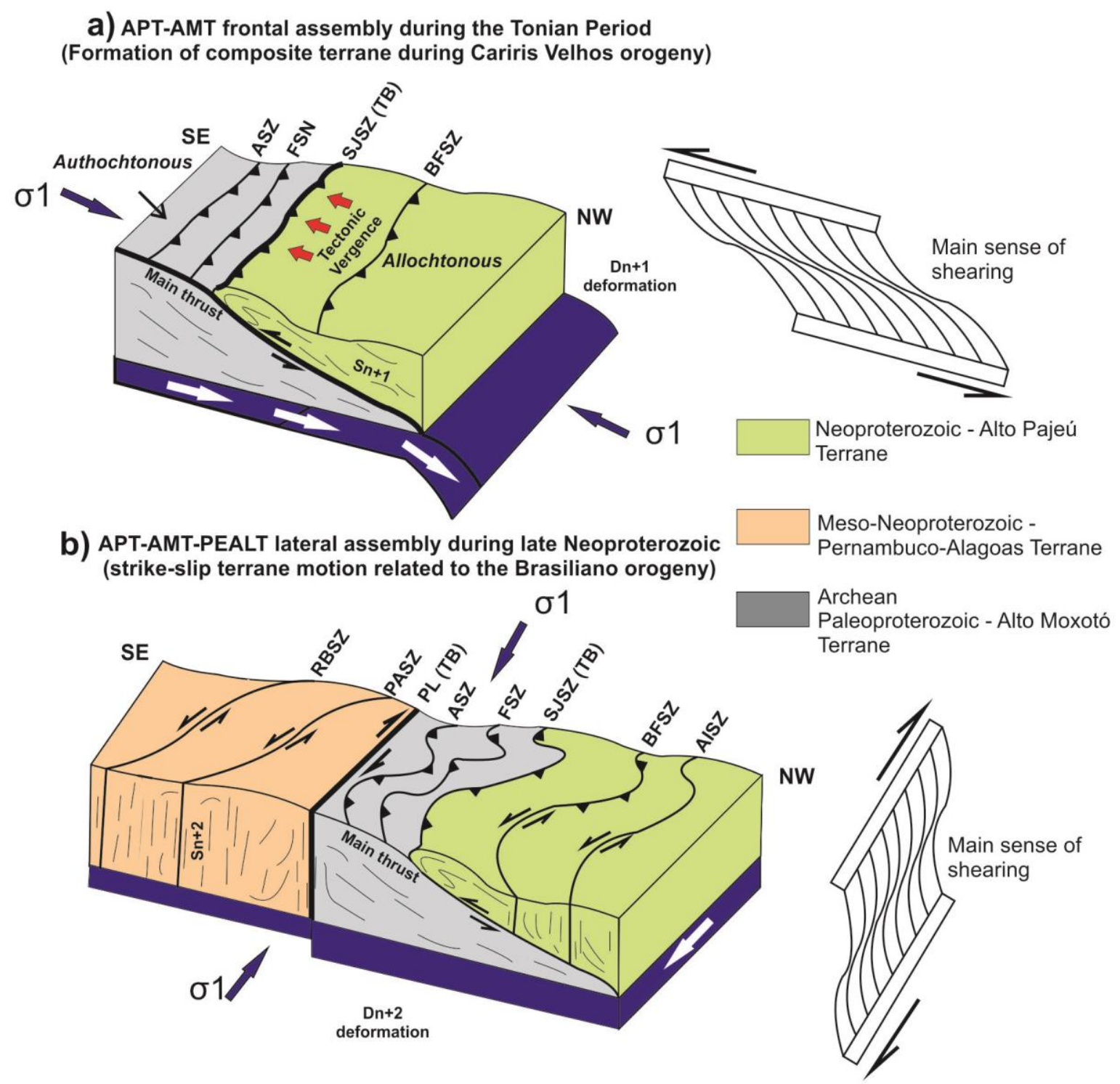

Figure 3.16 - Structural model for terrane collage between the studied terranes. Terranes - AMT - Alto Moxotó, APT = Alto Pajeú, RCT = Rio Capibaribe, PEALT = Pernambuco Alagoas. Shear zones $-\mathrm{RBSZ}=$ Riacho do Boi, PASZ = Poço da Areia, PL $=$ Pernambuco Lineament, ASZ = Airí, FSZ = Floresta, SJSZ = Serra de Jabitacá, BFSZ = Barra da Forquilha, AISZ = Afogados da Ingazeira. TB $=$ Terrane boundary .

\subsection{Conclusions}

Aeromagnetic and radiometric datasets combined with field-mapped structures suggest that the central portion of the Borborema Province, NE Brazil, might be formed via two distinct stages of terrane assembly. Polyphase deformation is mainly 
constrained by meso- and microscopic observations, including foliation transposition, distinct orientation of lineations as well as several kinematic criteria associated with major shear zones, including terrane boundaries, whereas geophysical data show contrasting signatures for the major units of the studied terranes.

The prominent mylonitic fabric associated with the Serra de Jabitacá shear zone is associated to a thrust terrane boundary between the Neoproterozoic Alto Pajeú and Archean-Paleoproterozoic Alto Moxotó terranes, and record an allochtonous relationship of the former with respect to the latter. This event is interpreted to result from convergent tectonics during the Cariris Velhos orogeny in the Early Neoproterozoic. Such amalgamation resulted in the formation of the Alto Pajeú-Alto Moxotó composite terrane during the Tonian (ca. 1000-960 Ma) and is closely associated to the ophiolitic fragment (i.e. Serrote das Pedras Pretas Suite).

Obliteration of thrust-related tectonites by later strike-slip shear zones resulted in regional folding and oblique and horizontal lineations. In addition to the internal trend of shear zones within the studied terranes, the major associated structure is the E-W Pernambuco Lineament. This structure is considered as the main record of assembly of the composite Alto Pajeú and Alto Moxotó terranes with the Pernambuco-Alagoas Terrane. According to our proposed model, this event took place during a metamorphic peak of the Brasiliano orogeny (ca. 650-590 Ma), developing high strain zones and local anatexites within major shear zones. Our results provide new insights for the discussion on the evolution of this part of West Gondwana.

\subsection{Acknowledgements}

The authors are thankful for the editor(s) of Journal of Structural Geology for their attention and the reviewers for their valuable time and suggestions. 


\subsection{References}

Almeida, F.F.M., Hasui, Y., Brito Neves, B.B., Fuck, R.A., 1981. Brazilian structural provinces: an introduction. Earth Science Reviews 18, 1-29.

Araujo, C.E.G., Cordani, G.U., Weinberg, R., Basei, M.A.S., Armostrong, R., Sato, K. 2014. Tracing Neoproterozoic subduction in the Borborema Province (NE- Brazil): clues from $\mathrm{U}-\mathrm{Pb}$ geochronology and $\mathrm{Sr}-\mathrm{Nd}-\mathrm{Hf}-\mathrm{O}$ isotopes on granitoids and migmatites. Lithos 202-203, 167-189.

Archanjo, C.J., Hollanda, M.H.B.M., Rodrigues, S.W., Brito Neves, B.B., 2008. Fabrics of pre- and syntectonic granite plutons and chronology of shear zones in the Eastern Borborema Province, NE Brazil. Journal of Structural Geology 30, 310-336.

Arthaud, M.H., Caby, R., Fuck, R.A., Dantas, E.L., Parente, C.V., 2008. Geology of the Northern Borborema Province, NE Brazil and its correlation with Nigeria, NW Africa. In: Pankhurst, R.J., Trouw, R.A.J., Brito Neves, B.B., De Wit, M.J. (Eds.), West Gondwana: Pre-Cenozoic correlations across the South Atlantic Region. Geological Society of London Special Publication, 49-67.

Bignold, S.M.; Treolar, P.J. 2003. Northward subduction of the Indian plate beneath the Koshitan island arc, Pakistan Himalaya: New evidence from isotopic data. Journal of the Geological Society, London 160, 377-384.

Black R., Liégois, J.P., Latouche L., Caby R., Bertrand J.M. 1994. Pan-African displaced terranes in the Tuareg Shield (Central Sahara). Geology 22, 641-644.

Buslov, M.M., Watanabe, T., Fujiwara, Y., Iwata, K., Smirnova, L.V., Yu Safonova, I., Semakov, N.N., Kiryanova, A.P. 2004. Late Paleozoic faults of the Altai region, Central Asia: tectonic pattern and model of formation. Journal of Asian Earth Sciences 23, 655671.

Brito Neves, B.B., 1975. Regionalização Geotectônica Do Précambriano Nordestino (Phd thesis). Universidade de São Paulo, São Paulo, p. 198.

Brito Neves, B.B., Santos, E.J., Schmus, W.R.Q., 2000. Tectonic history of the Borborema Province. In: Umberto Cordani; Edson José Milani; Antonio Thomaz Filho; 
Diogenes de Almeida Campos (Org.). Tectonic Evolution of South America. Rio de Janeiro: 31st International Geological Congress, pp. 151-182. Special Publication.

Brito Neves, B.B., Fuck, R.A., Pimentel, M.M. 2014. The Brasiliano collage in South America: a review. Brazilian Journal of Geology 44, 493-518.

Caby, R. 2003. Terrane assembly and geodynamic evolution of central-western Hoggar: a synthesis. Journal of African Earth Sciences 37, 133-159.

Carvalho, M.J., 2005. Evolução tectônica do domínio Marancó-Poço Redondo: Registro das orogêneses Cariris Velhos e Brasiliana na Faixa Sergipana, NE do Brasil. Universidade Estadual de Campinas, Campinas, p. 192 (PhD thesis).

Cawood, P.A.; Buchan, C. 2007. Linking accretionary orogenesis with supercontinent assembly. Earth Science Reciews 82, 217-256.

Cawood, P.A.; Kroner, A.; Collins, W.J.; Kusky, T.M.; Mooney, W.D.; Windley, B.F. 2009. Accretionary orogens through earth history. Geological Society London Special Publications 318, 1-36.

Cawood, P. A., Leitch, E.C., Merle, R.E., Nemchin, A.A. 2011a. Orogenesis without collision: Stabilizing the Terra Australis accretionary orogen, eastern Australia. Geological Society of America Bulletin 123, 2240-2255.

Cawood, P.A., Pisarevsky, S., Leitch, E.C. 2011b. Unraveling the New England Orocline, Eastern Gondwana Accretionary Margin. Tectonics, 30, TC5002, doi:10.1029/2011TC002864.

Caxito, F.A., Ulhein, A., Dantas, E.L., 2014a. The Afeição augen-gneiss Suite and the record of the Cariris Velhos Orogeny (1000-960 Ma) within the Riacho do Pontal fold belt, NE Brazil. Journal of South American Earth Sciences 51, 12-27.

Caxito, F.A., Ulhein, A., Stevenson, R., Ulhein, G. 2014b. Neoproterozoic oceanic crust remmants in northeast Brazil. Geology 45, 387-390.

Collins, W.J., Vernon, R.H., Clarke, G.L. 1991. Discrete Proterozoic structural terranes associated with low-P, high-T metamorphism, Anmatjira Range, Arunta Inlier, central Australia: Tectonic implications. Journal of Structural Geology 13, 1157-1171. 
Collins, W.J. 2002. Hot orogens, tectonic switching, and creation of continental crust. Geology 30, 535-538.

Coney, P.J.; Jones, D.L.; Monger, J.W.H. 1980. Cordilleran suspect terranes. Nature 288, 329-333.

Colpron, M.; Nelson, J.L.; (eds) 2006. Paleozoic evolution and metallogeny of Pericratonic Terranes at the Anciente Pacific Margin of North America, Canadian and Alaskan Cordillera. Geological Association of Canada, Special Paper, 45.

Cordani, E.G., Pimentel, M.M., Aráujo, C.E.G., Fuck, R.A., 2013. The significance of the Transbrasiliano-Kandi tectonic corridor for the amalgamation of West Gondwana. Brazilian Journal of Geology 43, 583-597.

Correa, R.T., Vidotti, R.A., Oksum, E. 2016. Curie surface of Borborema Province, Brazil. Tectonophysics 679, 73-87.

Corsinini, M., Figueiredo, L.L., Caby, R., Feraud, G., Ruffet, H., Vauchez, A., 1998. Thermal history of the Pan-African/Brasiliano Borborema Province of northeast Brazil deduced from 40Ar/39Ar analysis. Tectonophysics 285, 103-117.

Costa, F.G., Palheta, E.S.M., Rodrigues, J.B., Gomes, I.P.G., Vasconcelos, A.M. 2015. Geochemistry and $\mathrm{U}-\mathrm{Pb}$ zircon ages of plutonic rocks from the Algodões granitegreenstone terrane, Troia Massif, Northern Borborema Province, Brazil: Implications for Paleoproterozoic subdiction-accretion processes. Journal of South American Earth Sciences 59, 45-68.

Cruz, R.F., Pimentel, M.M., Accioly, A.C.A., 2015. Provenance of metasedimentary rocks of the western Pernambuco-Alagoas domain: contribution to understand the Neoproterozoic tectonic evolution of the southern Borborema Province. Journal of South American Earth Sciences 58, 82-99.

Dantas, E.L., Souza, Z.S., Wernick, E., Hackspacher, P.C., Martin, H., Xiadong, D., Li, J.W., 2013. Crustal growth in the 3.4-2.7 Ga São José do Campestre Massif, Borborema Province, NE Brazil. Precambrian Research 227, 12-156. 
Davison, I., McCarthy, M., Powell, D., Torres, H.H.F., Santos, C.A., 1995. Laminar flow in shear zones: the Pernambuco Shear Zone, NE-Brazil. Journal of Structural Geology 17, 153-161.

Dickinson, W.R.; 2004. Evolution of the North American Cordillera. Annual Reciews of Earth and Planetary Sciences 32:13-45.

Fetter, A.H., Van Schmus, W.R., dos Santos, T.J.S., Arthaud, M., Nogueira Neto, J., Arthaud, M. 2000. U-Pb and Sm-Nd geochronological constraints on the crustal evolution and basement architecture of Ceara State, NW Borborema Province, NE Brazil: implications for the existence of the Paleoproterozoic supercontinent Atlantica. Revista Brasileira de Geociencias 30, 102-106.

Fetter, A.H., Santos, T.J.S., Van Schmus, W.R., Hackhpacher, P.C., Brito Neves, B.B., Arthaud, M.H., Nogueira Neto, J.A., Wernick, E. 2003. Evidence for Neoproterozoic continental arc magmatism in the Santa Quiteria Batholith of Ceará State, NW Borborema Province, NE Brazil: implications for the assembly ofWest Gondwana. Gondwana Research 6, 265-273.

Guimarães, I.P., Silva Filho, A.F., Melo, S.C., Macambira, M.B. 2005. Petrogenesis of A-Type Granitoids from the Pajeú-Paraíba Belt, Borborema Province, NE Brazil: Constraints from geochemistry and isotopic composition. Gondwana Research 8, 347362.

Hollanda, M.H.B.M., Archanjo, C.J., Batista, J.R., Souza, L.C. 2015. Detrital zircon ages and $\mathrm{Nd}$ isotope compositions of the Seridó and Lavras da Mangabeira basins (Borborema Province, NE Brazil): Evidence for exhumation and recycling associated with a major shift in sedimentary provenance. Precambrian Research 258, 186-207.

Howell, D.G. 1995. Principles of Terrane analysis. Chapman \& Hall, 245 pp.

Isles, D.J., Rankin, L.R. 2013. Geological interpretation of aeromagnetic data. Perth: The Australian Society of Exploration Geophysicists, 357 p.

Jaques, A.L., Wellman, P., Whitaker, A., Wyborn, D. 1997. High resolution geophysics in modern geological mapping. Journal of Australian Geology and Geophysics 17, 159173. 
Jarrard, R.D. 1986. Terrane motion by strike-slip faulting of fore-arc slivers. Geology $14,780-783$.

Kozuch, M., 2003. Isotopic and trace element geochemistry of Early Neoproterozoic gneissic and metavolcanic rocks in the Cariris Velhos Orogen of the Borborema Province, Brazil, and their bearing tectonic setting (PhD thesis). Kansas University, Lawrence, p. 199.

Kusky, T.M., Bradley, D.C. 1999. Kinematic analysis of melange fabrics: examples and applications from the McHugh Complex, Kenai Peninsula, Alaska. Journal of Structural Geology

Lages, G.A., Dantas, E.L. 2016. Floresta and Bodocó Mafic-Ultramafic Complexes, western Borborema Province, Brazil: geochemical and isotope constraints for evolution of a Neoproterozoic arc environment and retro-eclogitic hosted Ti-mineralization. Precambrian Research 280, 95-119.

Lima, M.V.A.G., Berrocal, J., Soares, J.E.P., Fuck, R.A. 2015. Deep seismic refraction experiment in northeast Brazil: New constraints for Borborema province evolution. Journal of South American Earth Sciences 58, 335-349.

Miller, H.G., Singh, V. 1994. Potential field tilt - a new concept for location of potential field sources. Journal of applied Geophysics 32, 213-217.

Monié, O., Caby, R., Arthaud, M.H., 1997. The Neoproterozoic Brasiliano orogeny in northeast Brazil: 40Ar/39Ar and petrostructural data from Ceará. Precambrian Research 81, 241-264.

Neves, S.P., Mariano, G., 1999. Assessing the tectonic significance of a large-scale transcurrent shear zone system: The Pernambuco lineament, northeastern Brazil. Journal of Structural Geology 21, 1369-1383.

Neves, S.P., Bruguier, O., Bosch, D., Silva, J.M.R., Mariano, G., 2008. U-Pb ages of plutonic and metaplutonic rocks in the southern Borborema Province (NE Brazil): timing of Brasiliano deformation and magmatism. Journal of South American Earth Sciences 25, 285-297. 
Neves, S.P., 2015. Constraints from zircon geochronology on the tectonic evolution of the Borborema Province (NE Brazil): widespread intracontinental Neoproterozoic reworking of a Paleoproterozoic accreationary orogeny. Journal of South American Earth Sciences 58, 150-164.

Neves, S.P., Lages, G.A., Brasilino, R.G., Miranda, A.W.A., 2015. Paleoproterozoic accretionary and collisional processes and the build-up of the Borborema Province (NE Brazil): Geochronological and geochemical evidenve from the Central Domain. Journal of South American Earth Sciences 58, 165-187.

Oliveira, R.G., 2008. Arcabouço Geofísico, Isostasia e causas do magmatismo cenozóico da Província Borborema e de sua Margem Continental (NE do Brasil) (PhD thesis). Universidade Federal do Rio Grande do Norte, Natal, p. 411.

Oliveira, E.P., Windley, B.F., Araújo, M.N.C., 2010. The Neoproterozoic Sergipano orogenic belt, NE Brazil: a complete plate tectonic cycle in western Gondwana. Precambrian Research 181, 64-84.

Padilha, A.L., Vitorello., Í., Pádua, M.B., Marcelo., Fuck, R.A. 2016. Deep magnetotelluric signatures of the early Neoproterozoic Cariris Velhos tectonic event within the Transversal sub-province of the Borborema Province, NE Brazil. Precambrian Research 275, 7-83.

Pfiffner, O.A. 2006. Thick skinned and thin-skinned styles of continental contraction. Special Paper of Geological Society of America 414, 153-177.

Pubellier, M., Meresse, F. 2013. Phanerozoic growth of Asia: Geodynamic processes and evolution. Journal of Asian Earth Sciences 72, 118-128.

Puchkov, V.N. 2009. The evolution of the Uralian orogen. Geological Society of London Special Publications 327, 161-195.

Reid, A.B., Allson, J.M., Granser, H., Miett, A.J., Somerton, I.W. 1990. Magnetic interpretation in three dimensions using Euler deconvolution. Geophysics 55, 80-91.

Sales, A.O., Santos, E.J., Lima, E.S., Santos, L.C.M.L., Brito Neves, B.B.B. 2011. Evolução petrogenética e tectônica do Evento Cariris Velhos na região de Afogados da 
Ingazeira (PE), Terreno Alto Pageú, Província Borborema. Geologia USP - Série Científica 11, 101-121.

Santos, A.C.L., Padilha, A. L., Fuck, R. A., Pires, A. C. B., Vitorello, I.,Pádua, M. B. 2014. Deep structure of a stretched lithosphere: Magnetotelluric imaging of the southeastern Borborema province, NE Brazil. Tectonophysics 610, 39-50, 2014.

Santos, E.J., 1995. O complexo granítico Lagoa das Pedras: acresção e colisão na região de Floresta (Pernambuco), Província Borborema (PhD thesis). Instituto de Geociências da Universidade de São Paulo, São Paulo, p. 228.

Santos, E.J., Medeiros, V.C., 1999. Constraints from granitic plutonism on proterozoic crustal growth of the Transverse Zone, Borborema Province, NE-Brazil. Revista Brasileira de Geociências 29, 73-84.

Santos, E.J., Brito Neves, B.B., Van Schmus, W.R., Oliveira, R.G., Medeiros, V.C., 2000. An overall view on the displaced terrane arrangement of the Borborema Province, NE Brazil. In: International Geological Congress, 31th, Rio de Janeiro, Brazil, General Symposia, Tectonic Evolution of South American Platform, pp. 5-9.

Santos, E.J., Nutman, A.P., Brito Neves, B.B., 2004. Idades SHRIMP U-Pb do Complexo Sertânia: implicações sobre a evolução tectônica da Zona Transversal, Província Borborema. Geologia USP - Série Científica 4, 1-12.

Santos, E.J., Van Schmus,W.R., Kozuch, M., Brito Neves, B.B., 2010. The Cariris Velhos tectonic event in northeast Brazil. J. South American. Earth Sciences. 29, 61-76.

Santos, L.C.M.L., Dantas, E.L., Santos, E.J., Santos, R.V., Lima, H.M., 2015a. Early to late Paleoproterozoic magmatism in NE Brazil: the Alto Moxoto Terrane and its tectonic implications for the pre-West Gondwana assembly. Journal of South American Earth Sciences.58, 188-209.

Santos, L.C.M.L., Fuck, R.A., Santos, E.J., Dantas, E.L., 2015b. Análise tectônica de terrenos: metodologia, aplicação em cinturões orogênicos e exemplo das províncias Tocantins e Borborema, Brasil. Geonomos 22, 51-63.

Santos, T.J.S., Amaral, W.S., Ancelmi, M.F., Pitarello, M.Z., Fuck, R.A., Dantas, E.L., 2015c. U-Pb age of the coesite-bearing eclogite from NW Borborema Province, NE 
Brazil: Implications for western Gondwana assembly. Gondwana Research 28, 11831196.

Silva Filho, A.F., Guimarães, I.P., Ferreira, V.P., Armstrong, R., Sial, A.N. 2010. Ediacaran Águas Belas pluton, Northeastern Brazil. Evidence on age emplascement. Gondwana Research 17, 676-687.

Silva Filho, A.F., Guimarães, I.P., Van Schmus, W.R., Armstrong, R., Silva, J.M.R., Osako, L., Concentino, L., Lima, D., 2014. SHRIMP U-Pb zircon geochronology and Nd signatures of supracrustal sequences and orthogneisses constrain the Neoproterozoic evolution of the Pernambuco-Alagoas domain, southern part of the Borborema Province, NE Brazil. International Journal of Earth Sciences 21, 2155-2190.

Stern R.J.; Scholl, D.W. 2010. Yin and yang of continental crust creation and destruction by plate tectonic processes. International Geology Review 52, 1-31.

Tatsumi, Y. 2005. The subduction factory: How it operates on Earth. GSA Today 15, 410.

Tetreault, J. L.;Buiter, S. J. H. 2012. Geodynamic models of terrane accretion: Testing the fate of island arcs, oceanic plateaus, and continental fragments in subduction zones, Journal of Geophysical Research 117, 1-12.

Tetreault, J.L.; Builter, S.J.H; 2014. Future accreted terranes: a compilation of island arcs, oceanic plateaus, submarine ridges, seamounts, and continental fragments. Solid Earth 5, 1243-1275.

Thompson, D.T. 1982. EULDPH: a new thecnique for making computer assisted depth estimate from magnetic data. Geophysics 47, 31-37.

Tozer, R.S.J., Buttler, R.W.H., Corrado, S. 2002. Comparing thin- and thick skinned thrust tectonic models of the Central Apennines, Italy, in Continental Collision and the Tectono-Sedimentary Evolution of Forelands. Stephan Mueller Publication Series 1, pp. 181. European Geosciences Union Strasbourg, France.

Trompette, R., 1994. Geology of Western Gondwana, Pan African-Brasiliano Aggregation of South America and Africa. A.A. Balkema, Rotterdam, p. 350. 
Van Schmus, W.R., Brito Neves, B.B., Hackspacher, P.C., Babinski, M., 1995. U/Pb and $\mathrm{Sm} / \mathrm{Nd}$ geochronologic studies of the eastern Borborema Province, Northeast Brazil: initial conclusions. Journal of South American Earth Sciences 8, 267-288.

Van Scmmus, W.R., Oliveira, E.P., Silva Filho, A.F., Toteu, F., Penaye, J., Guimarães, I.P., 2008. Proterozoic links between the Borborema Province, NE Brazil, and the Central African Fold Belt. Geological Society of London Special Publication 294, 6669.

Vauchez, A., Egydio-Silva, M. 1992. Termination of a Continental-Scale-Strike-Slip Fault in partially melted crust: The West-Pernambuco Shear Zone, Northeast Brazil. Geology 20, 1007-1010.

Vauchez, A., Neves, S.P., Caby, R., Corsini, M., Edydio-Silva, M., Arthaud, M., Amaro, V.E., 1995. The Borborema shear zone system, NE Brazil. Journal of South American Earth Sciences 8, 247-266.

Viegas, L.G., Archanjo, C.J., Hollanda, M.H.B.M., Vauchez, A., 2014. Microfabrics and zircon U-Pb (SHRIMP) chronology of mylonites from the Patos shear zone (Borborema Province, NE Brazil). Precambrian Research 243, 1-17.

Viegas, L.G., Menegon, L., Archanjo, C.J. 2016. Brittle grain-size reduction of feldspar, phase mixing and strain localization in granitoids at mid-crustal conditions (Pernambuco shear zone, NE Brazil). Solid Earth 7, 375-396.

Weingerg, R.F., Sial, A.N., Mariano, G., 2004. Close spatial relationship between plutons and shear zones. Geological Society of America Bulletin 32, 377-380. 


\title{
4. ARTIGO CIENTÍFICO 2:
}

\section{NEOARCHEAN CRUSTAL GROWTH AND PALEOPROTEROZOIC REWORKING ON THE BORBOREMA PROVINCE, NE BRAZIL: INSIGHTS FROM GEOCHEMICAL AND ISOTOPIC DATA OF TTG AND METAGRANITIC ROCKS OF THE ALTO MOXOTÓ TERRANE.}

Lauro Cézar Montefalco de Lira Santos ${ }^{1,2, *}$; Elton Luiz Dantas ${ }^{1}$; Peter A. Cawood³; Edilton José dos Santos ${ }^{4}$; Reinhardt A. Fuck ${ }^{1}$;

${ }^{1}$ Instituto de Geociências, Universidade de Brasília, Brazil; ${ }^{2}$ Unidade Acadêmica de Mineração e Geologia, Universidade Federal de Campina Grande, Brazil; 32Department of Earth Sciences, University of St. Andrews, UK; ${ }^{4}$ Serviço Geológico do Brasil CPRM, Brazil.

*Corresponding author. E-mail: lauromontefalco@gmail.com

\begin{abstract}
In the Borborema Province (NE Brazil), Archean and Paleoproterozoic rocks are concentrated in basement inliers/exotic blocks, such as the Alto Moxotó Terrane. Petrographic, geochemical and U-Pb and $\mathrm{Sm}-\mathrm{Nd}$ isotopic data from two basement metagranitic suites within the terrane provide the evidence for Neoarchean $(2.6 \mathrm{Ga})$ and Paleoproterozoic $(2.1 \mathrm{Ga})$ subduction-related events. The Riacho das Lajes Suite is made of medium to coarse-grained hornblende and biotite-bearing metatonalites and metamonzogranites. Whole-rock geochemical data indicate that these rocks represent calcic, magnesian and meta- to peraluminous magmas, and have unequivocal affinities with high-Al low-REE tonalite-trondhjemite-granodiorites (TTG). Zircon U-Pb data from two samples of this suite indicate that they were emplaced at $2.6 \mathrm{Ga}$. The suite has Neoarchean depleted mantle model ages ( $\left.\mathrm{T}_{\mathrm{DM}}\right)$ and slightly negative to positive $\varepsilon \mathrm{Nd}(\mathrm{t})$, indicating slight crustal contamination. The overall geochemical and isotopic data indicate that a Neoarchean intraoceanic setting was the most probable scenario for the genesis of the Riacho das Lajes magma via the melting of basaltic oceanic crust submitted to high-pressure eclogite facies conditions. On the other hand, the Floresta
\end{abstract}


Suite forms an E-W elongated batholith, the composition of which varies from tonalites to granodiorites. Geochemical data indicate that this suite shares similarities with calcic to calc-alkalic magmas with magnesian and metaluminous to slightly peraluminous characteristics. Other geochemical characteristics observed in part of it include anomolous $\mathrm{Ni}, \mathrm{V}$ and $\mathrm{Cr}$ contents, as well as high large-ion litophile elements (LILE) values. The suite yields $\mathrm{U}-\mathrm{Pb}$ zircon ages of approximately $2.1 \mathrm{Ga}$, Archean to Paleoproterozoic $\mathrm{T}_{\mathrm{DM}}$ ages, and negative to positive $\varepsilon \mathrm{Nd}(\mathrm{t})$ values, suggesting new crust formation and reworking of Archean crust, in addition to mantle metasomatism, reflecting mixed sources. The most likely tectonic setting for the Floresta Suite magmas involved crustal thickening by terrane accretion, coeval to slab break off.

Key-words: Crustal growth; continental reworking; Neoarchean TTG; West Gondwana; Borborema Province.

\subsection{Introduction}

The preserved record for the generation of continental crust is episodic, its formation being related to juvenile magmatism in subduction-related (Niu and $\mathrm{O}^{\prime} \mathrm{Hara}$ 2009; Cawood et al., 2013) or mantle plume (Condie, 1998) settings. Conversely, recycling of continental crust back to the mantle may have been active since the Paleoarchean, and coeval with crustal growth events (Cavosie et al., 2006; Arndt, 2013).

In the Archean, high heat production and accretion rates favored the generation of specific petrogenetic associations, such as komatiites in granite-greenstone terranes and voluminous tonalite-trondhjemite-granodiorite (TTG) magmas (Martin et al., 2005). In contrast, during the Archean-Proterozoic transition, changes in geodynamic processes resulted in decrease of TTG production, followed by strong increase in the generation of more potassic and less sodic granitoids (Shirey and Hanson 1984, Smithies and Champion, 2000; Laurent et al., 2014). In several cratonic blocks, these compositional changes are recorded in juvenile plutonic and volcanic suites related to a major $2.7 \mathrm{Ga}$ crustal growth event, which is considered to be one of the most important periods of continental crust generation in Earth's history (Condie, 2000; Hawkesworth et al., 2010; Condie and Kröner 2013; Wan et al., 2014). 
Experimental studies indicate that unlike normal calc-alkaline magmas, TTGlike geochemical signature results from a moderate degree of partial melting of hydrated basaltic (low-K) crust at pressures high enough to stabilize the garnet \pm amphibole paragenesis (Rapp and Watson 1995; Martin et al., 2005). The classical tectonic scenario for TTG genesis is usually attributed to subduction-related settings, in which partial melting of subducted oceanic crust (meta-basalts) under high pressure conditions is induced by elevated Archean geothermal gradients (Defant and Drummon, 1990; Rapp et al., 2003; Halla et al., 2009; Laurent et al., 2014). Other possible scenarios include the development of a thick oceanic plateau due to mantle plume over oceanic crust (Smithies and Champion 2000; Zegers and van Keken 2001; Condie, 2005) and the delamination of an over-thickened mafic crust (Johnson et al., 2013).

On the other hand, younger and well-consolidated continental magmatic arcs are widespread in the Paleoproterozoic (Rogers and Santosh, 2003; Zhao et al., 2004). They are responsible for the production of a large compositional range of volcanic and plutonic rocks (Tatsumi and Eggins, 1995). In such settings, the most accepted mechanism of melt generation involves progressive releasing of aqueous fluids or silicate melts from the subducting slab. This gradual process induces partial melting of the overlying mantle wedge by reducing its solidus temperature (van Keken et al., 2002; Kelley et al., 2010), leading to the formation of magmas with unique arc geochemistry. It has been argued that the generation of these arc magmas contributes directly to formation of new crust and/or reworking of early formed continental margins (Rudnick, 1995; Hollister and Andronicos, 2006).

In this work, we present whole-rock geochemical and Sm-Nd isotopic data and $\mathrm{U}-\mathrm{Pb}$ zircon age determinations of the Neoarchean Riacho das Lajes and Paleoproterozoic Floresta suites of the Alto Moxotó Terrane, central portion of the Borborema Province (BP). Our main goals are to: (1) identify the nature of their source and tectonic setting; (2) determine the timing of intrusions and associated crust-related processes (crustal growth vs. reworking); and (3) constrain geodynamic processes through integration of data from across the Borborema Province and other Archean and Paleoproterozoic domains of West Gondwana. 


\subsection{Regional Geology}

\subsubsection{Borborema Province}

The Borborema Province was defined by as the Precambrian northeastern portion of the South American platform (Almeida et al., 1981). It is located in the central part of West Gondwana and is part of a large and complex orogenic system that extends through the Pan-African fold-belts between Togo to the north and Cameroon to the east in Central Africa (Figure 4.1a; Brito Neves 1975; Trompette 1994; Van Schmus et al., 2008, 2011).

The geologic configuration of the $\mathrm{BP}$ includes basement complexes with Paleoproterozoic belts/terranes as well as local exposures of Archean nuclei, in which constituent orthogneisses and migmatites have been inferred to have formed by subduction-related and minor within-plate-related processes (Brito Neves et al., 2000; Santos et al., 2000; Fetter et al., 2003; Van Schmus et al., 2008; Martins et al., 2009; Brito Neves, 2011). In addition, the province includes early to late Neoproterozoic supracrustal fold belts and magmatic arcs containing widespread granitic magmatism related to Brasiliano orogenesis (Santos and Medeiros, 1999; Kozuch, 2003; Santos et al., 2010; 2015; Araújo et al., 2014a,b,c; Caxito et al., 2014a, b).

The province is transected by a complex network of E-W and NE-SW crustalscale strike-slip shear zones with mylonites up to several kilometers across (Archanjo et al., 2008; Oliveira, 2008; Cordani et al., 2013; Lima et al., 2015). It is divided into the northern, Transversal and southern sub provinces (Figure 4.1b; Van Schmus et al., 1995, 2008; Brito Neves et al., 2000). Available isotopic and structural data have led to the suggestion that the province was subjected to a polycyclic tectonic evolution involving episodes of accretion of tectono-stratigraphic terranes during the Neoproterozoic (Santos 1996; Santos and Medeiros, 1999; Santos et al., 2010; Brito Neves et al., 2005, 2014; Santos et al., 2015b). However, an intracontinental orogen hypothesis has also been invoked for the evolution of the BP (Neves, 2015). 


\subsubsection{Transversal sub province}

The Transversal sub province occupies the central portion of the BP and is limited by the regional Patos and Pernambuco lineaments to the north and south, respectively. It was affected by the Cariris Velhos orogenic event at ca. 1.0 Ga, followed by the Brasiliano orogeny at ca. 0.6 Ga (Van Schmus et al., 1995; Santos, 1996; Santos and Medeiros, 1999; Santos et al., 2010; Brito Neves et al., 2014).

From west to east five terranes are recognized in the Transversal sub province: São José do Caiano (SJC), Piancó-Alto Brígida (PABT), Alto Pajeú (APT), Alto Moxotó (AMT), and Rio Capibaribe (RCT) (Figure 4.1c). NE-SW trending strike-slip shear zones cut across these crustal blocks. Neoproterozoic felsic and mafic plutons occur throughout the sub province along with Paleo- and Neoproterozoic supracrustal fold belts (Santos and Medeiros, 1999). Archean to Early Paleoproterozoic units are not widespread and are mostly concentrated in the Alto Moxotó Terrane and in some areas of the Rio Capibaribe Terrane.

\subsection{The Alto Moxotó Terrane}

The Alto Moxotó Terrane (AMT) is a high-grade metamorphic block composed of metaplutonic suites, including metagranites, orthogneisses, migmatites and maficultramafic rocks in addition to supracrustal sequences that are Paleoproterozoic in age (Rodrigues and Brito Neves 2008; Santos et al., 2004, 2012, 2013). This terrane is bounded to the north by the Alto Pajeú Terrane, which is represented by a series of Tonian (ca. $1.0 \mathrm{Ga}$ ) metaplutonic rocks that have been affected by the thrust tectonics of the Serra de Jabicacá Nappe (Santos and Medeiros 1999; Rodrigues and Brito Neves, 2008). The southern limit of the AMT is represented by the strike-slip Pernambuco lineament and the Congo Cruzeiro do Nordeste shear zone (Brito Neves et al., 2013).

A long-lived Paleoproterozoic tectono-magmatic evolution for the AMT, divided into three main tectonic pulses, has been proposed by Santos et al. (2015a). The first tectonic event was responsible for the emplacement of intermediate metaplutonic rocks with a magmatic arc-related signature, which are Siderian in age with both juvenile and crustal characteristics. The second event is represented by granodioritic to tonalitic gneisses and mafic-ultramafic magmatism, also in a subduction-related setting, 
but with a stronger crustal signature at 2.1-2.0 Ga. This event was responsible for multiple sheet-like intrusions that are widespread throughout the terrane. The final tectonic pulse is characterized by within-plate bimodal magmatism dated at $1.6 \mathrm{Ga}$ (Santos et al., 2015a). Additionally, an important high-grade metamorphic event took place at $1.9 \mathrm{Ga}$ (Neves et al., 2015), which is possibly related to eclogite to granulite facies transition described in the region (Santos et al., 2015a). Cambrian granites occur along the margins of the Alto Moxotó Terrane.

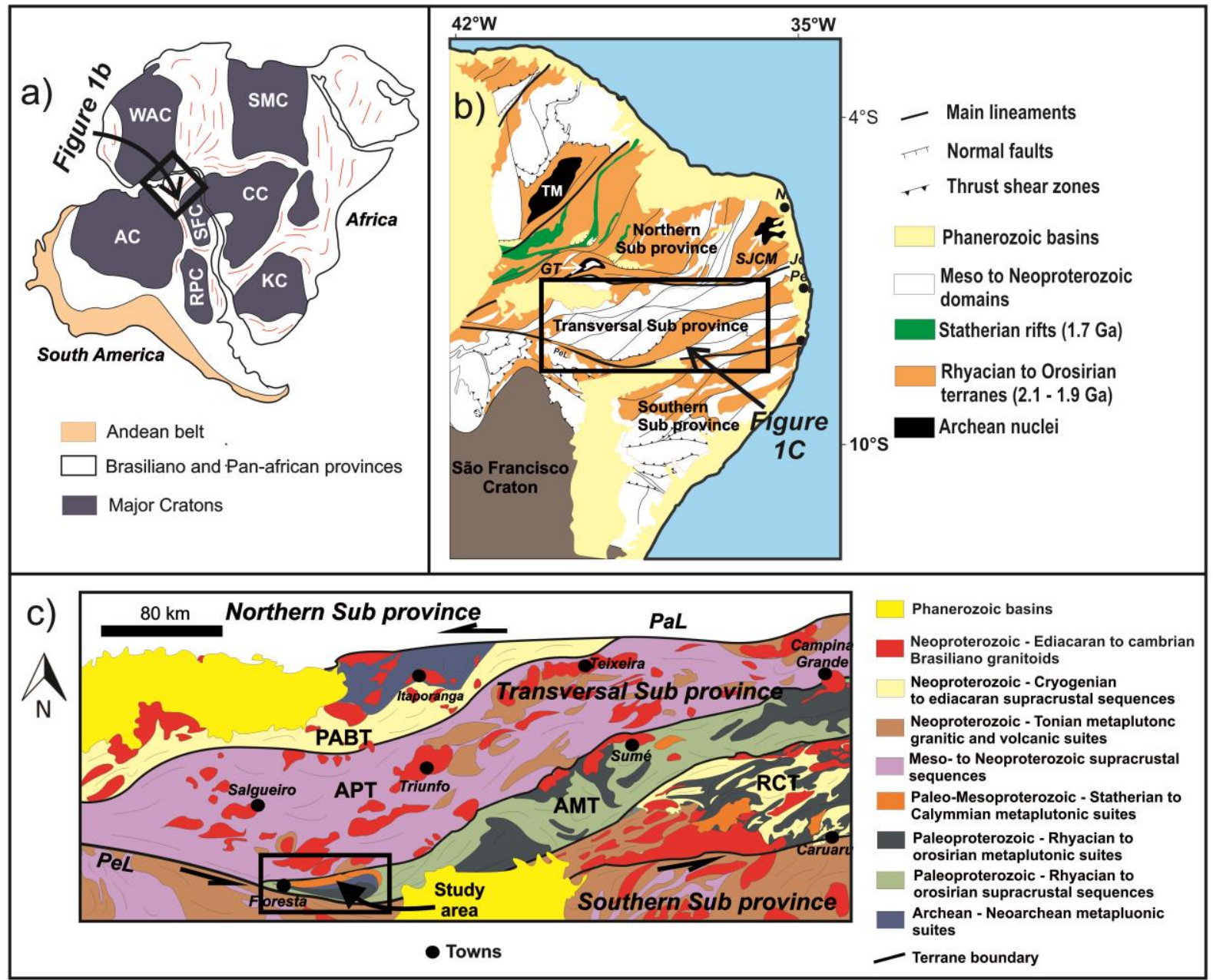

Figure 4.1 - Geodynamic context of the Borborema Province in Pre-Drift reconstruction for West Africa and northeast South America, b) tectonic framework of the Borborema Province and c) Simplified geological map of the Transversal Sub province and its terranes with the study area highlighted. 


\subsection{Local Geology}

The study area is located in the SW portion of the Alto Moxotó Terrane, close to Floresta, and comprises a series of metaplutonic and supracrustal sequences (Figure 4.2). The Riacho das Lajes Suite is separated by shear zones with a thrust sense of movement from the Statherian Riacho do Navio Suite to the north and the Orosirian Sertânia Complex to the south, respectively. The Floresta Suite forms a batholith in the south rim of the terrane, in tectonic contact with the southern sub province along the Pernambuco Lineament. Contact relationship with the supracrustal rocks of the Sertânia Complex is poorly understood due to the strong Ediacaran deformation that affected the region.

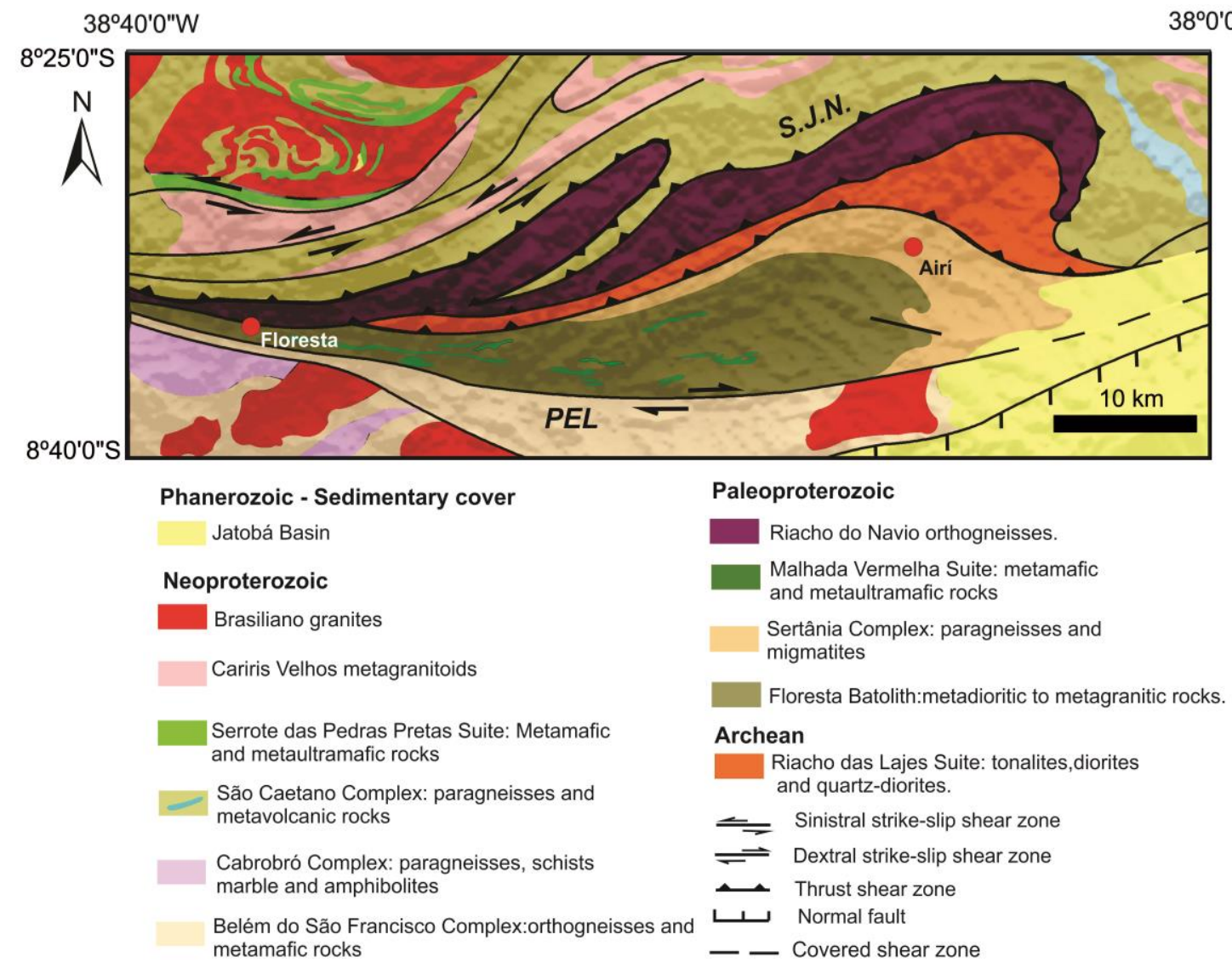

Figure 4.2 - Geological map of the Airi area with the location of the Riacho das Lajes and Floresta suites. PEL = Pernambuco Lineament, SJN = Serra de Jabitacá Nappe. The red circles of Floresta and Airí represents the main towns of the area. 


\subsubsection{Riacho das Lajes Suite}

This suite was previously described as a series of white metagranitoids and orthogneisses with trondhjemitic affinity (Santos, 1995). It is formed of leucocratic rocks that occur as stock-like intrusions elongated E-W and NE-SW due to Neoproterozoic Brasiliano deformation. The suite occupies the central part of the study area, where two main facies were identified: i) undeformed, isotropic or eventually slightly deformed granitoids (Figure 4.3a); and ii) strongly foliated members forming orthogneisses (Figure 4.3b) that show mafic-felsic streaky compositional banding and scarce occurrences of E-W oriented, $30-50 \mathrm{~cm}$ long mafic enclaves. Additionally, partially migmatized facies occur locally and are characterized by metatexites with well-preserved paleosome, but local bands of leucosomes are present and occur parallel to the regional foliation forming stromatic fabrics (Figure 4.3c). Discordant quartzfeldspar veins also occur, which is a typical feature of vein-structured migmatites.

Petrographic analysis indicates that these rocks correspond to holo-leucocratic, leucocratic and mesocratic rocks, ranging from tonalite to granodiorite in composition, but quartz monzodiorites and monzogranites are also present (Figure 4.4). They are medium to coarse-grained (1.0 to $5.0 \mathrm{~mm}$ in diameter). The less deformed samples are characterized by hypidiomorphic to allotriomorphic granular textures, in contrast with dominant granoblastic polygonal texture in the foliated members. The groundmass mineralogy of Riacho das Lajes granitoids includes plagioclase (oligoclase-andesine) (40-42\%) and quartz (35-38\%) (Figure 4.5a). Plagioclase crystals form subhedral and anhedral grains that commonly exhibit myrmekitic intergrowths with irregular quartz crystals. In addition, the former is locally zoned, indicating abrupt changes in magma composition, whereas the quartz grains are euhedral, subhedral or anhedral. Polygonal shapes are common in the most deformed samples, suggesting intense recrystallization.

Quartz grains also occur as static rotated grains or exhibit ribbon-like structures with frequent undulose extinction, which reflects the intense post-crystallization deformation (Figure 4.5b). In some samples, the local deformation is also characterized by grain orientations alternating millimeter-size felsic and mafic minerals (mainly biotite), thus indicating the involvement of an important metamorphic segregation. Kfeldspar grains $(\sim 10 \%)$ exhibit perthitic intergrowth but are rare. Subhedral microcline grains exhibiting crosshatching crystal twinning mainly represent this mineral, but 
anhedral and irregular orthoclase aggregates are also common. Dark to reddish brown biotite (5-15\%) (Figure 4.5c) and greenish hornblende (5-10\%) are widespread in all samples and represent the main ferromagnesian phases. Minor clinopyroxene crystals are also present (2-3\%). The accessory minerals include subhedral titanite (1-2\%), anhedral allanite (1-2\%), euhedral apatite (1\%) and euhedral to subhedral zircon (1\%). Subhedral magnetite (2-3\%) is the main opaque mineral, and the occurrence of subhedral chlorite crystals $(1 \%)$ represents the main secondary phase, which we interpret as the result of biotite alteration.

\subsubsection{Floresta Suite}

This suite corresponds to part of the Floresta Complex defined by Lima et al. (1985). Several petrographic types were distinguished by Santos (1995), including amphibolites, metatonalites, metadiorites and metagranodiorites. According to these authors, the Floresta Complex corresponds to the regional basement of the entire Alto Moxotó Terrane. Recent work by Santos et al. (2013, 2015a) and as part of the present work reveals that the Floresta Complex consists of a series of metaplutonic suites on the basis of field, petrographic and isotopic data. In this paper, we describe a new unit of the Floresta Complex, which we distinguish as the Floresta Suite.

The Floresta Suite is an approximately $30 \mathrm{~km}$ long, E-W elongated batholith with interleaving mafic-ultramafic rocks of the Orosirian Malhada Vermelha Suite, which was originally described by Santos (1995). Its shape is controlled by the strong influence of the Brasiliano strike-slip Pernambuco lineament in the south rim of the body. The suite shows strong structural zonation, with isotropic granitoids in its central part (Figures $4.3 \mathrm{~d}$ and $4.3 \mathrm{e}$ ) and progressively more deformed members towards its rims, forming orthogneissic facies with mafic-felsic compositional banding (Figure 4.3f) and mylonitic to ultra-mylonitic members, especially in the southern part. Local migmatization is also present and is characterized by discrete stromatic and folded structures. The main rock associations comprise biotite-bearing and hornblende-bearing metaplutonic members, including granodiorite, diorite, quartz diorite, tonalite and monzogranite (Figure 4.4). 
Fine-, medium- and coarse-grained (0.25 to $5 \mathrm{~mm}$ in diameter) inequigranular rocks with dominat hypidiomorphic to allotriomorphic textures characterize the suite (Figures $4.5 \mathrm{~d}, 4.5 \mathrm{e}$ ). Granoblastic polygonal texture is very common in the most deformed samples and is characterized by equidimensional subhedral polygonal grains forming local triple junctions. Subdioblastic and xenoblastic textures are present in strongly foliated samples. Mineralogically the suite consists of a subdiomorphic aggregate mass of quartz (35-40\%), plagioclase (35-40\%) and K-feldspar (10-15\%), and hornblende and biotite as the main mafic phases. Quartz grains occur as subhedral to anhedral crystals exhibiting undulose extinction, whereas plagioclase crystals (oligoclase to andesine) are primarily euhedral to subhedral with local mymerkitic intergrowth. Euhedral to subhedral microcline is the most common potassic feldspar, but orthoclase grains are also present, exhibiting patch and vein type perthites, ass well as quartz and biotite inclusions.

The main mafic phases are represented by large subhedral to euhedral greenish hornblende crystals (10-15\%, Figure 4.5f) and subhedral to anhedral bent flakes of dark brown biotite (5-7\%), which can also replace hornblende crystals. Anhedral clinopyroxene clusters are present in lesser content (2\%). Euhedral titanite (1-2\%) is the most common accessory phase in these rocks, indicating early crystallization in the magma. Well-formed apatite and zircon crystals are other common accessories, representing less than $2 \%$ of the modal composition. Opaque minerals are represented by small magnetite crystals (less than $1 \%$ ). Chlorite crystals are rare and result from biotite alteration (less than $1 \%$ ). 

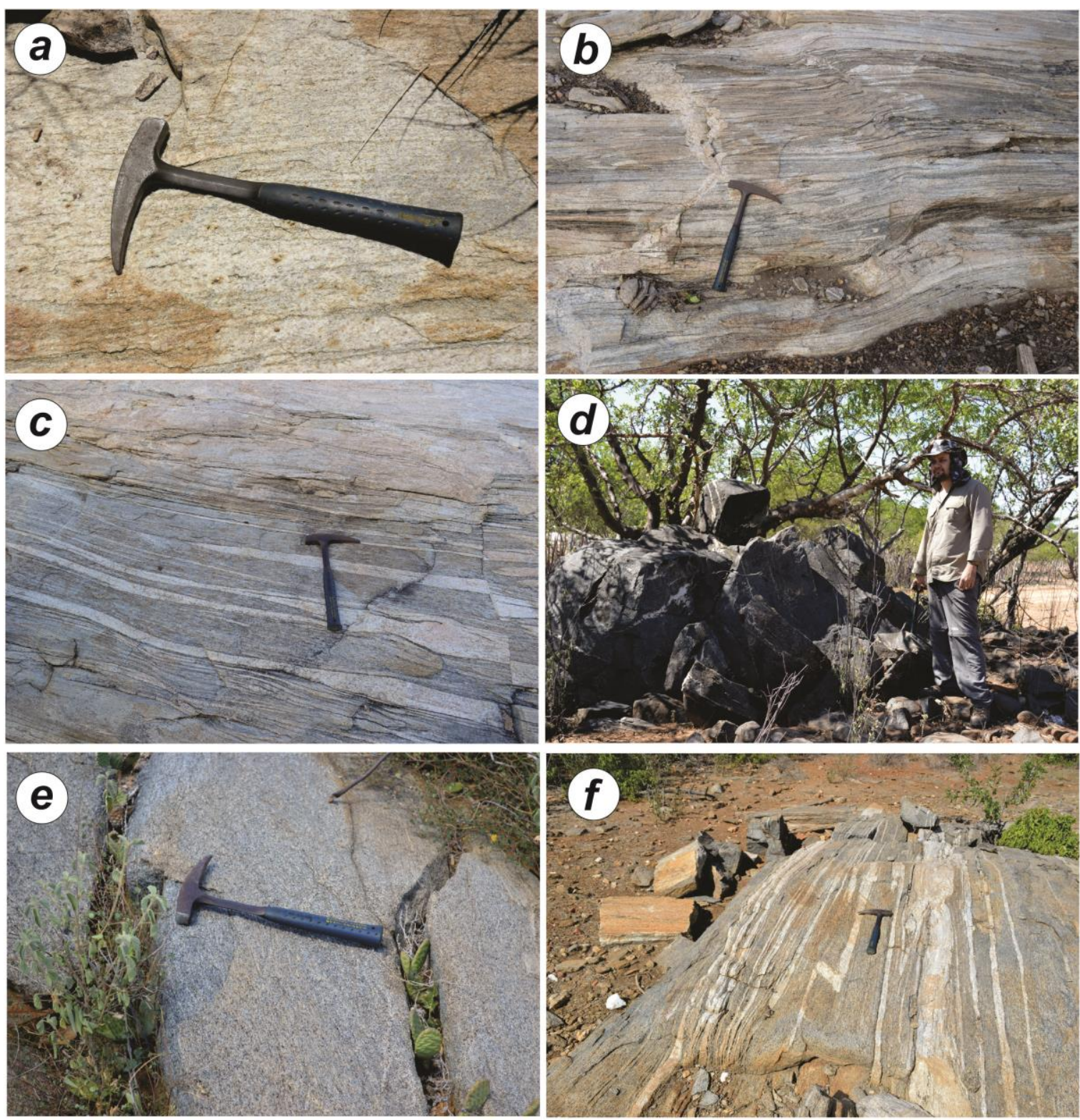

Figure 4.3 - Field aspects of metaplutonic studied rocks. a) Discretely foliated metagranitoid (Riacho das Lajes suite); b) Biotite gneiss with well developed compositional bending (Riacho das Lajes suite); c) Stromatic metatexite with tonalitic protolith (Riacho das Lajes suite); d) Isotropic metagranitoid with granodioritic composition (Floresta suite); e) Isotropic metatonalite (Floresta Suite); e) Compositional banding of tonalitic to granodioritic orthogneiss (Floresta Suite). 


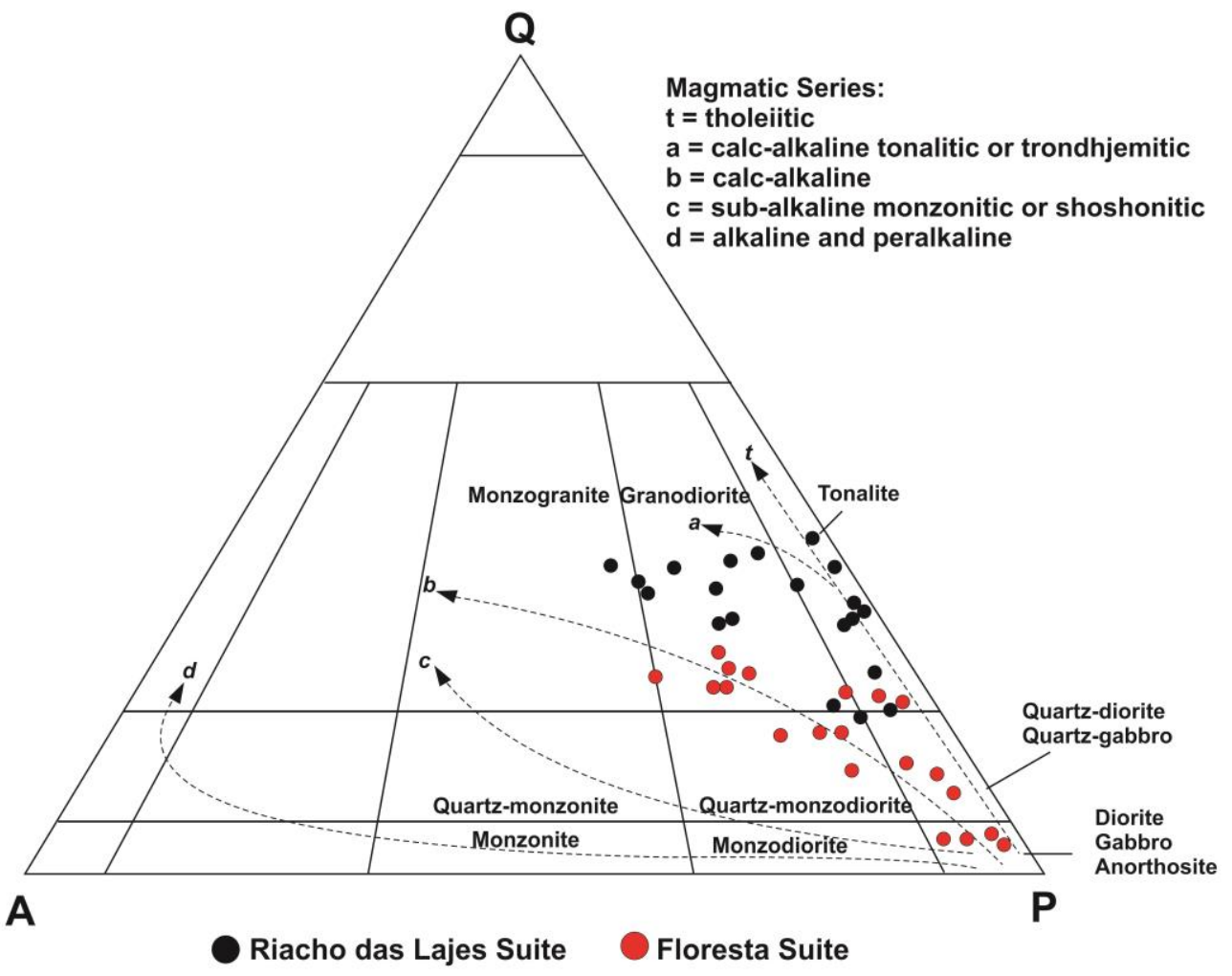

Figure 4.4 - Modal composition of studied samples from Riacho das Lajes and Floresta suites reported in the Q-A-P triangular diagram from Streckeisen (1976). 

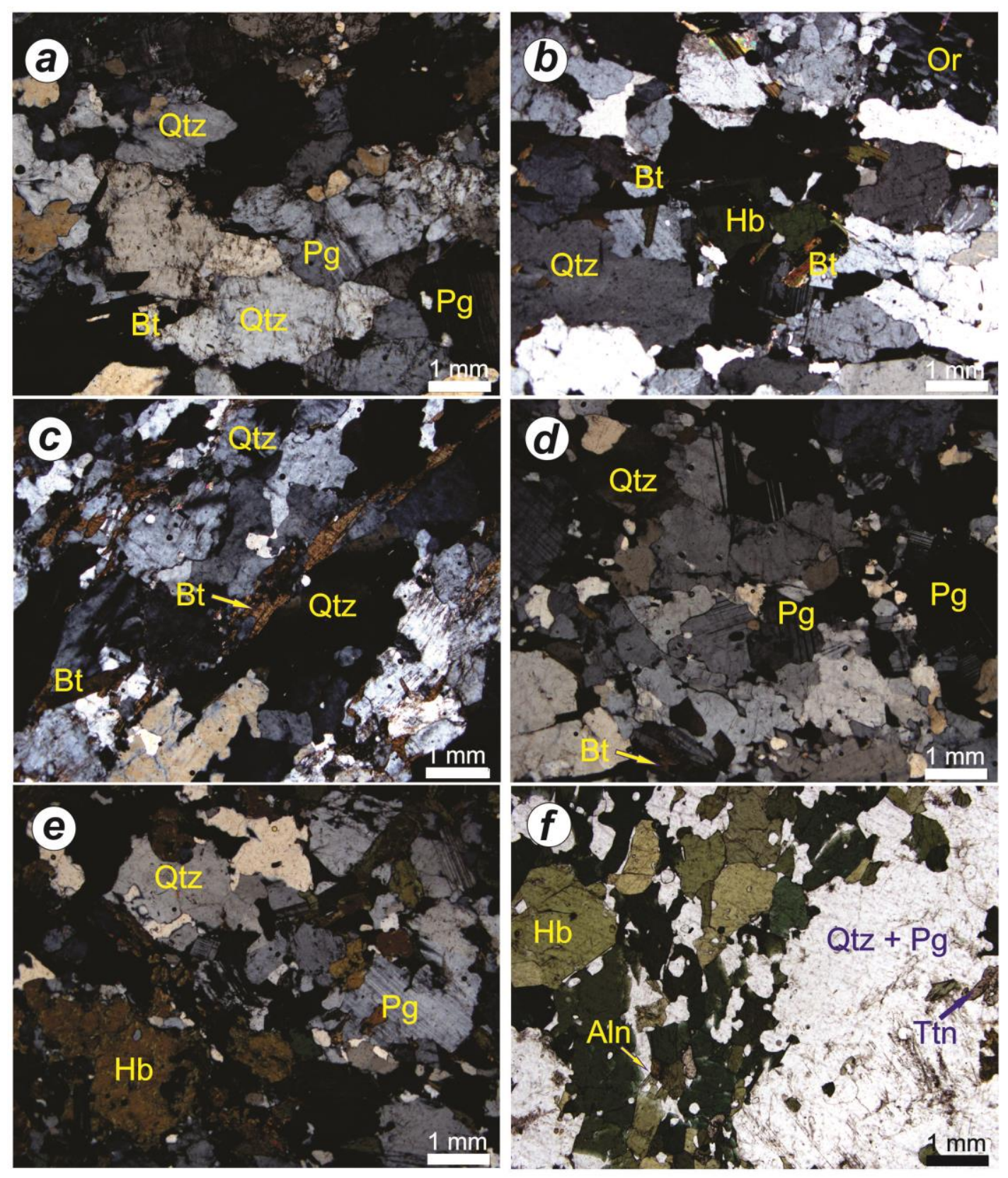

Figure 4.5 - Photomicrographs of the studied rocks (a to e $=$ crossed nicols and $\mathrm{f}=$ parallel nicols). a) Hipidiomorphic granular texture in metatonalite (Riacho das Lajes Suite); b) Granoblastic texture exhibiting deformed qtz grains in metagranodiorite (Riacho das Lajes Suite); c) Elongated biotite quatrz within quartz-plagioclase aggregates in metagranodiorite (Riacho das Lajes Suite); d) and e) Hipidiomorphic granular textures in metatonalite and metadiorite respectively (Floresta Suite) with granoblastic texture, f) Greenish hornblende aggregates in metagranitic rock (Floresta Suite). 


\subsection{Analytical Procedures}

Fresh representative rock samples were analyzed for major and trace elements at Acme Analytical Laboratories Ltd. (Canada). Major elements were determined by inductively coupled plasma-emission spectrometry, with a detection limit of $0.01 \%$ and precision of $\pm 0.1 \%$. Trace elements were analyzed by inductively coupled plasma-mass spectrometry (ICP-MS), with detection limits between 0.01 and $0.5 \mathrm{ppm}$ and precision of $\pm 5 \%$. Geochemical diagrams in were elaborated using Igpet 06 software, GCDkit, Petrograph and Excel sheets.

Four samples, two for each studied unit, were selected for zircon $\mathrm{U}-\mathrm{Pb}$ age dating at the Geochronology Laboratory of Universidade de Brasilia, Brazil. The samples were initially crushed and sieved, and then the heavy minerals were separated using conventional gravimetric and magnetic methods. Zircon grains were then handpicked using a binocular microscope and mounted on epoxy resin for Laser Ablation Inductively Coupled Plasma Mass Spectrometry (LA-MC-ICP-MS) isotope ratio acquisition. Data reduction was performed following Bühn et al. (2009) and Matteini et al. (2009). Isotopic analyses were performed on a Thermo Finnigan Neptune Multi-collector ICPMS equipped with a secondary electron multiplier-ion counter at the Geochronology Lab of the University of Brasilia. Cathodoluminescence and backscattered images were used to investigate the internal structure of the zircon crystals prior to each analysis. Only coherent interval analyses were chosen to avoid signal mixed ages. Normalization was performed with internal GJ standard zircon (608.5 \pm 1.5 Ma; Jackson et al., 2004), and the age calculations were performed using in-house developed Excel spreadsheets.

For the Sm-Nd data, an aliquot of 24 samples from both studied suites was analyzed, following the method described by Gióia and Pimentel (2000). Whole rock powders (ca. $50 \mathrm{mg}$ ) were mixed with a ${ }^{149} \mathrm{Sm}^{150} \mathrm{Nd}$ spike solution and dissolved in Savillex capsules. Extraction of $\mathrm{Sm}$ and $\mathrm{Nd}$ from whole-rock samples followed conventional cation exchange techniques, using Teflon columns containing LN-Spec resin (HDEHP - diethylhexyl phosphoric acid supported on PTFE powder). Sm and Nd samples were loaded on Re evaporation of double-filament assemblies, and the isotopic measurements were also performed on a multi-collector Triton, Thermocientific at the University of Brasilia. Uncertainties in the $\mathrm{Sm} / \mathrm{Nd}$ and ${ }^{143} \mathrm{Nd} /{ }^{144} \mathrm{Nd}$ ratios are better than $\pm 0.4 \%(1 \sigma)$ and $\pm 0.005 \%(1 \sigma)$, respectively, based on repeated analyses using the 
international rock standards BHVO-1 and BCR-1. ${ }^{143} \mathrm{Nd} /{ }^{144} \mathrm{Nd}$ ratios were normalized to a ${ }^{146} \mathrm{Nd} /{ }^{144} \mathrm{Nd}$ of 0.7219 , and the decay constant used was $6.54 \times 10^{-12}$. Depleted mantle model age values were calculated using the DePaolo (1981) model.

\subsection{Results}

\subsubsection{Geochemistry}

\subsubsection{Riacho das Lajes Suite}

Eleven samples of metagranitoid and orthogneiss from this suite were selected for geochemical analysis, and the results are listed in Table 4.1. On the ternary diagram of normative feldspar composition (O'Connor, 1965) the samples show a relatively narrow compositional range, corresponding mostly to granodiorites and tonalites, but granite and quartz monzonite compositions are also present (Figure 4.6a).

$\mathrm{SiO}_{2}$ values for the Riacho das Lajes Suite range from 69.8 to 76.4 wt.\%, $\mathrm{Na}_{2} \mathrm{O}$ from 3.98 to 5.07 wt. $\%$, and $\mathrm{K}_{2} \mathrm{O}$ from 0.83 to 4.23 wt. $\%$. On the alkali-lime index vs. silica diagram the samples are calcic ( $\mathrm{CaO}$ ranging from 2.54 to 3.39 wt.\%, Figure 4.6b). The samples are mostly magnesian, with minor iron enrichment $(\mathrm{MgO}$ and $\mathrm{FeO}$ values ranging from 0.15 to $1.02 \mathrm{wt} . \%$ and 0.9 to $3.3 \mathrm{wt} . \%$, respectively), and are chemically similar to Cordilleran granites (Figure 4.6c). $\mathrm{Al}_{2} \mathrm{O}$ values range from 13.8 to 16.95 wt.\% and plot in the peraluminous and metaluminous fields of the A/NK vs. A/CNK diagram (Figure 4.6d). On the K-Na-Ca diagram, the samples show a small sodic tendency but also slight K enrichment, and they do not follow the trondhjemitic or the calc-alkaline trends (Figure 4.6e).

On primitive-mantle normalized multi-element diagram (spider diagram) the Riacho das Lajes Suite displays a uniform pattern (Figure 4.7a) characterized by moderate to high contents of large ion lithophile elements (LILE) and high field strength elements (HFSE). Strong $\mathrm{Nb}, \mathrm{P}$ and $\mathrm{Ti}$ negative anomalies are observed, in addition to discrete to moderate depletions of $\mathrm{Ce}, \mathrm{Sm}$ and $\mathrm{Lu}$ in most samples. $\mathrm{Pb}$ and $\mathrm{Zr}$ mark positive peaks. A steeper rare earth elements pattern in reference to chondrite is clearly observed in the studied samples (Figure $4.7 \mathrm{~b}$ ). This behavior is characterized by strong enrichment of light rare earth elements (LREE) with respect to most heavy rare 
earth elements $(\mathrm{HREE})\left([\mathrm{La} / \mathrm{Yb}]_{\mathrm{N}}=55.68-175.85\right)$. The samples also display a pronounced positive Eu peak (Eu/Eu* varying between 1.15 and 2.10).

\subsubsection{Floresta Suite}

Seventeen samples of the Floresta Suite were selected for whole-rock geochemical determination, and the results are given in Table 4.2. Chemically, they correspond primarily to tonalites, granites and granodiorites on the ternary diagram of normative feldspar composition (Figure 4.6a). They are characterized by $\mathrm{SiO}_{2}$, ranging from 52.5 to 76.7 wt. $\%$, whilst $\mathrm{Na}_{2} \mathrm{O}$ values are rather homogeneous and range from 2.52 to 4.22 wt.\%. $\mathrm{CaO}$ and $\mathrm{K}_{2} \mathrm{O}$ contents are variable, ranging from 1.15 to 8.83 wt.\% and 0.71 to $5.49 \mathrm{wt} . \%$, respectively. On the alkali-lime index vs. silica diagram, the samples show a calcic to calc-alkalic trend (Figure 4.6b). On the $\mathrm{FeOt} /(\mathrm{FeO}+\mathrm{MgO})$ diagram (Frost et al., 2001), they plot mainly in the magnesian field, sharing chemical similarities with classic Cordilleran type-granites ( $\mathrm{MgO}$ ranging from 0.23 to $5.22 \mathrm{wt} . \%$ and $\mathrm{FeO}$ ranging from 1.45 to $9.6 \mathrm{wt}$ \%, Figure 4.6c).

The $\mathrm{Al}_{2} \mathrm{O}_{3}$ values range from 13.15 to 20.8 wt.\%, and on the $\mathrm{A} / \mathrm{NK}$ vs. $\mathrm{A} / \mathrm{CNK}$ diagram, using the alumina saturation index, these rocks can be characterized as metaluminous to slightly peraluminous (Figure 4.6d), whereas on the K-Na-Ca diagram, although somewhat dispersed, tend to the calc-alkaline trend (Figure 4.6e). The primitive mantle-normalized spider diagram for the Floresta Suite displays moderate to high values of large ion lithophile elements (LILE). The high field strength elements (HFSE) behavior is marked by negative anomalies of $\mathrm{Nb}$; $\mathrm{P}$ and Ti also show important negative peaks (Figure 4.7c). In terms of rare earth elements (REE) content, the samples from this suite exhibit moderate to high fractionation of LREE compared to HREE $\left([\mathrm{La} / \mathrm{Yb}]_{\mathrm{N}}=7.07-108.70\right)$, and negative to positive Eu anomalies, which are generally induced by plagioclase accumulation in the melt $\left(\mathrm{Eu} / \mathrm{Eu}^{*}\right.$ varying between 0.38 and 2.09) (Figure 4.7d). 

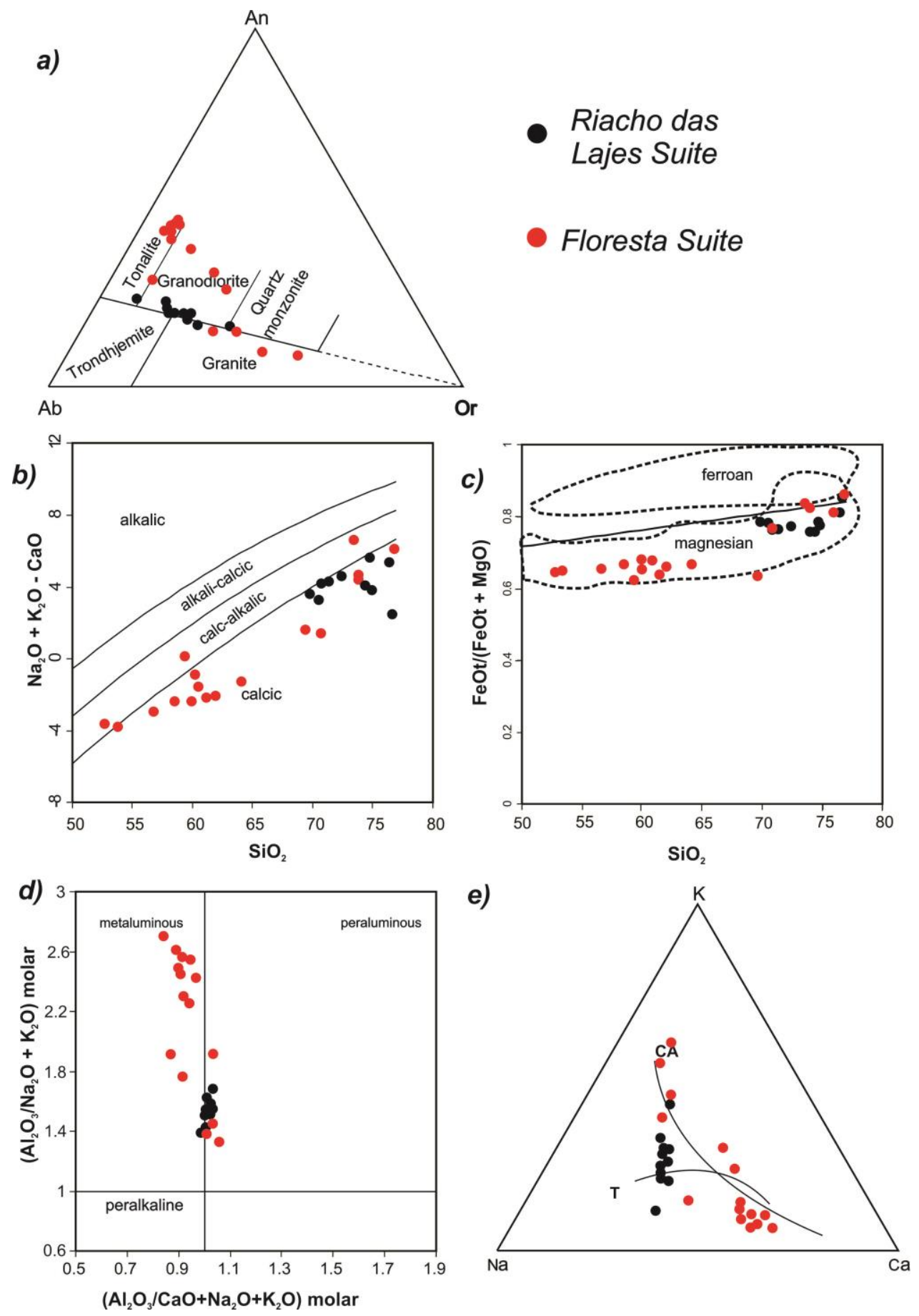

Figure 4.6 - Geochemical characteristics of the Riacho das Lajes and Floresta suites. a) Normative An-Ab-Or triangle (O'Connor, 1965); b) $\mathrm{SiO}_{2}$ vs. $\mathrm{Na}_{2} \mathrm{O}+\mathrm{K}_{2} \mathrm{O}-\mathrm{CaO}$ diagram (Frost et al. 2001); c) $\mathrm{SiO} 2$ vs. FeOt/(FeOt + MgO) diagram (Frost et al. 2001); d) $\mathrm{Al}_{2} \mathrm{O}_{3} /\left(\mathrm{Na}_{2} \mathrm{O}+\mathrm{K}_{2} \mathrm{O}\right)$ molar vs. $\left.\mathrm{Al}_{2} \mathrm{O}_{3} / \mathrm{CaO}+\mathrm{Na}_{2} \mathrm{O}+\mathrm{K}_{2} \mathrm{O}\right)$ molar diagram (Maniar and Picolli, 1989); e) Cationic Ca-Na-K diagram showing classical calc-alkaline and trondhjemitic (Barker and Arth, 1976) evolutions. 

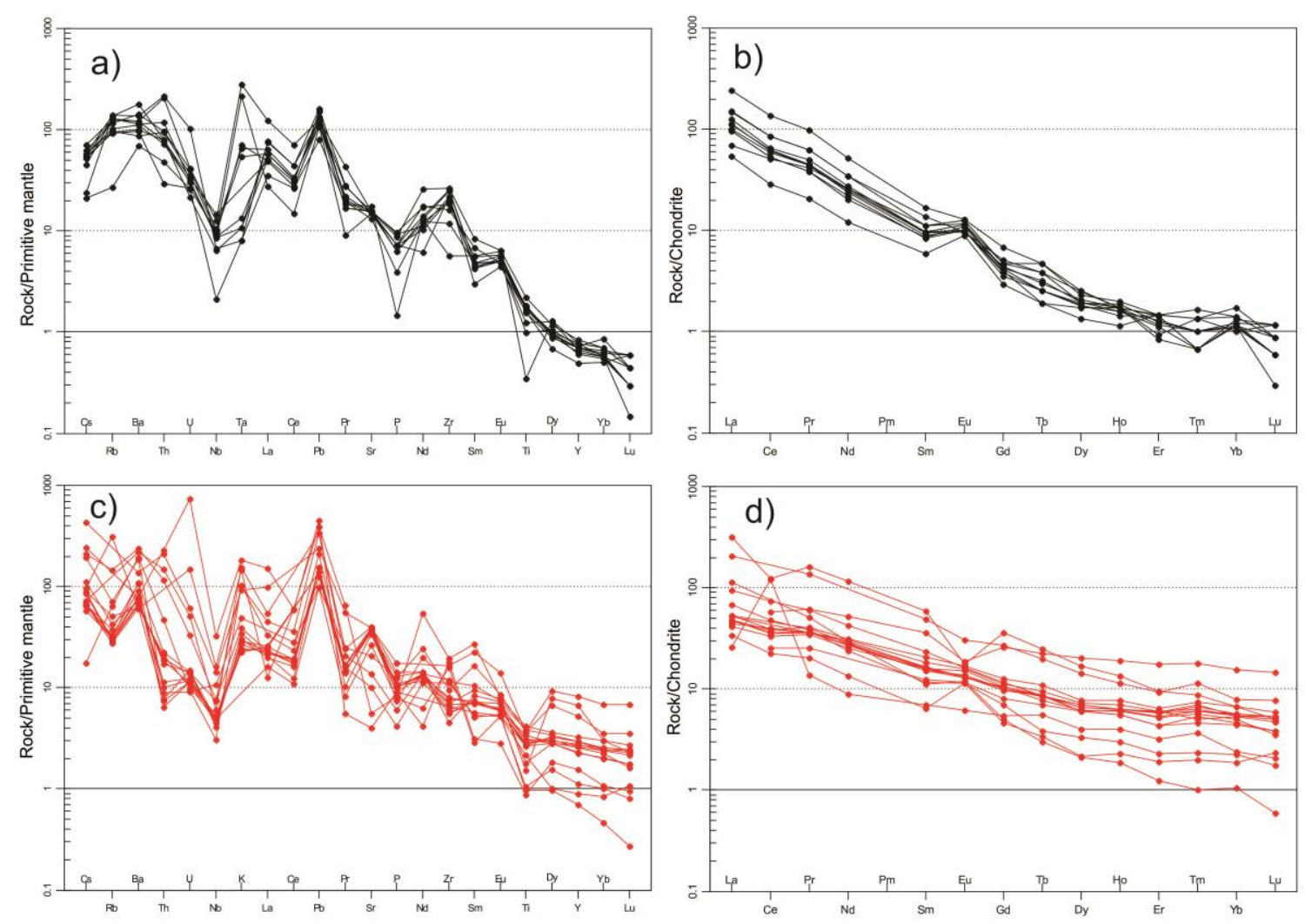

Figure 4.7 - a) Spider diagrams of trace elements abundances; b) REE abundances for rocks of the Riacho das Lajes Suite, 1995; c) Spider diagrams of trace elements abundances and b) REE abundances for rocks of the Floresta Suite. Spiderdiagrams were normalized by primitive mantle from Mcdonough and Sun, 1995 and REE normalized by Chondrite from Nakamura (1974). Black circles = Riacho das Lajes Suite, Red circles $=$ Floresta Suite .

\subsubsection{U-Pb Geochronology}

$\mathrm{U}-\mathrm{Pb}$ zircon data for the Riacho das Lajes and Floresta suites are presented in tables 4.3, 4.4, 4.5 and 4.6. Cathodoluminescence images were used as a guide for spot selection in representative zircon grains and are shown in Figure 4.8. 


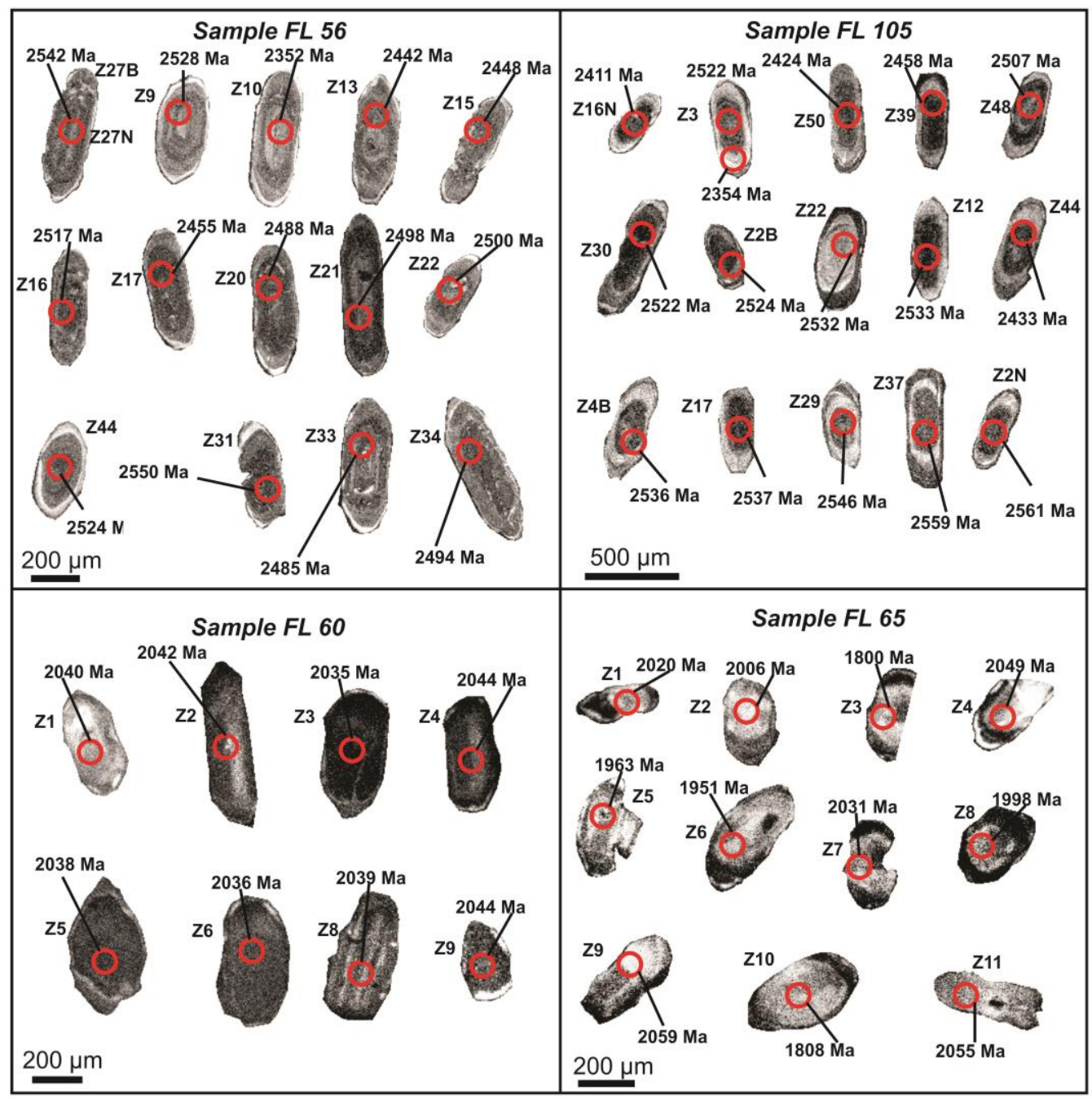

Figure 4.8 - Selected cathodoluminescene images of analyzed zircons for U-Pb geochronology.

\subsubsection{Riacho das Lajes Suite}

Sample FL-56 is a white to light-gray, coarse-grained metatonalite. This sample was collected $10 \mathrm{~km}$ north of Airi. The majority of the dated zircon grains are idiomorphic and present well-developed oscillatory zoning, with dimensions ranging from 220 to $500 \mu \mathrm{m}$. Most of the grains have a discrete metamorphic overgrowth due to later thermal events. However, most of the grains present $\mathrm{Th} / \mathrm{U}$ ratios varying from 0.10 to 0.46 , which attests to a magmatic origin. The analyses of zircon grains from this sample result in a Discordia line with an upper intercept of $2625 \pm 14 \mathrm{Ma}$ (MSWD $=3.9$ ), which is interpreted as the crystallization age of the tonalitic protolith (Figure 4.9). 
The second dated sample (FL-105) corresponds to a discretely banded granodiorite orthogneiss, collected near Airi. Zircon crystals from this sample are euhedral, subhedral and anhedral. Some exhibit oscillatory zoning and present dimensions of $500 \mu \mathrm{m}$ on average. The majority of the analyzed zircon grains present $\mathrm{Th} / \mathrm{U}$ ratios ranging from 0.12 to 0.4 , which correspond to igneous crystals, but in various grains pronounced metamorphic overgrowth can be observed, which is probably due to later thermal events that affected the region. The analyzed grains resulted in a Discordia line that yields an upper intercept age of $2643 \pm 18 \mathrm{Ma}$ (MSWD $=1.9$ ), which is interpreted as the crystallization age of the granodiorite protolith (Figure 4.10). The ages of $560 \pm 36 \mathrm{Ma}$ and $645 \pm 85 \mathrm{Ma}$ observed in the lower intercepts of samples FL56 and FL-105, respectively, are interpreted as the result of $\mathrm{Pb}$ loss during the Brasiliano orogeny that strongly affected most of the Borborema Province.

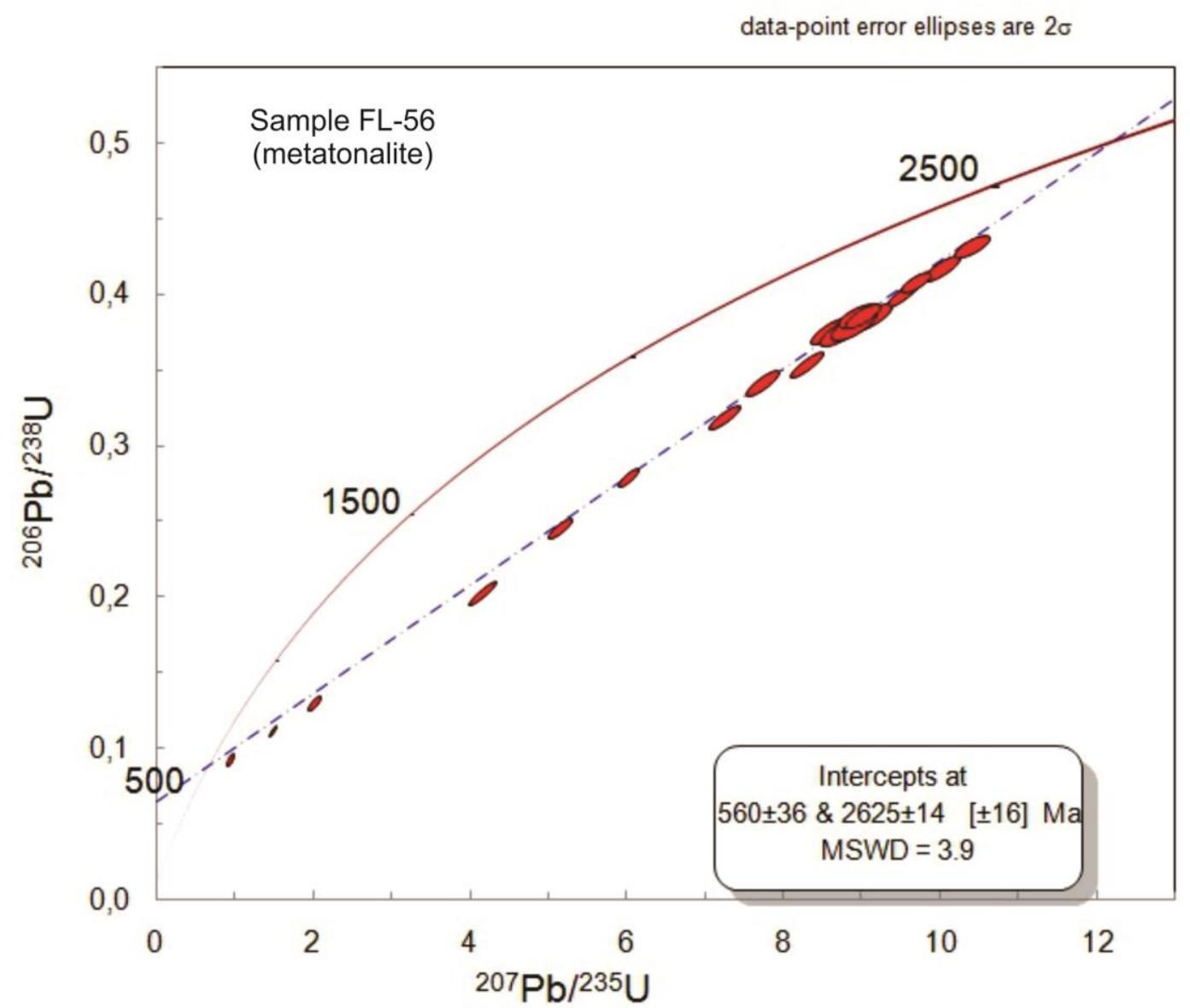

Figure 4.9 - U-Pb zircon age of metatonalite from the Riacho das Lages Suite (Sample FL-56). 


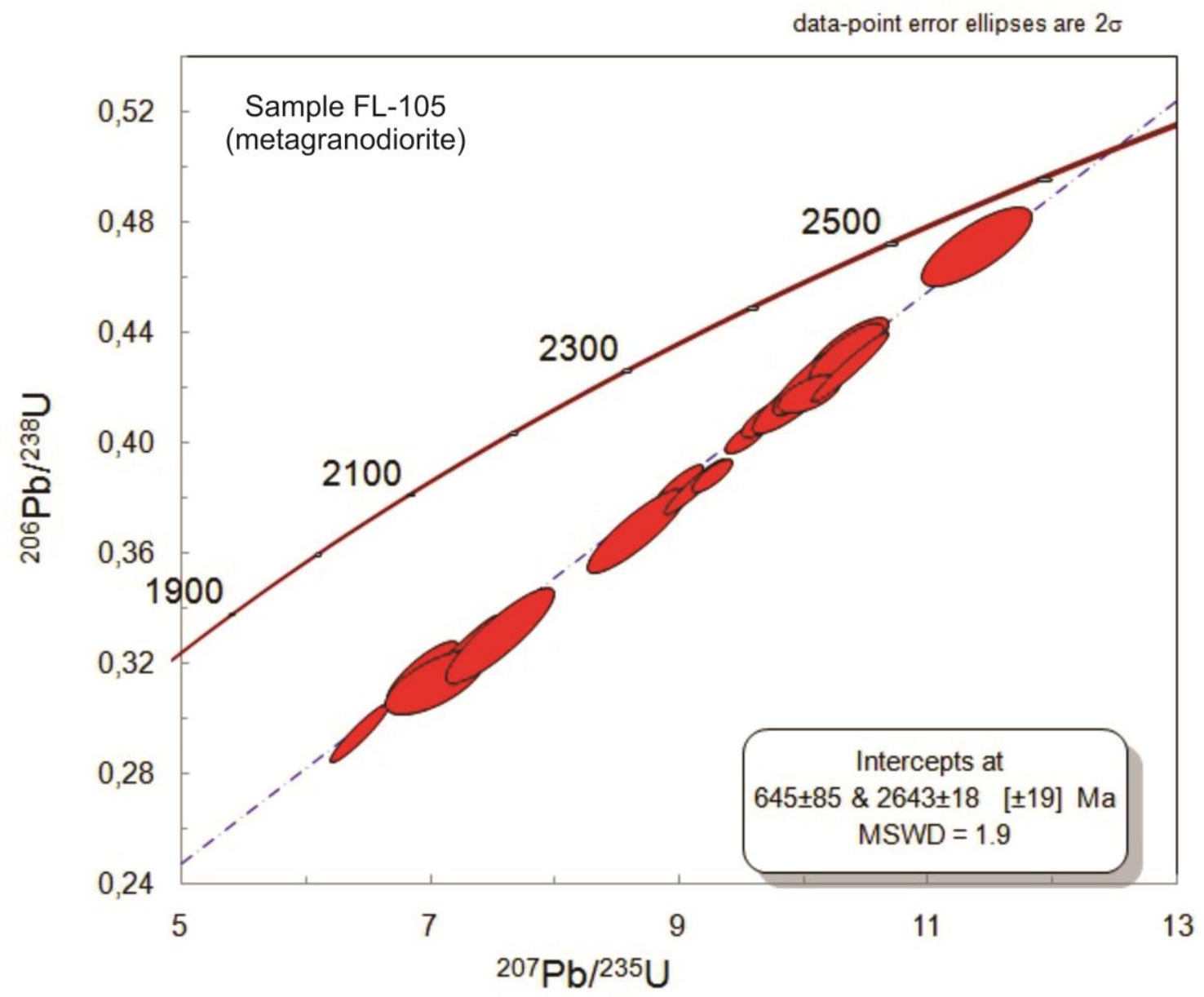

Figure 4.10 - U-Pb zircon age for a metagranodiorite of the Riacho das Lajes Suite (sample FL-105).

\subsubsection{Floresta Suite}

Sample FL-65 corresponds to a dark gray inequigranular, biotite-bearing, medium-grade metadiorite with pronounced metamorphic foliation, collected near the Barragem locality. The selected hypidiomorphic to idiomorphic zircon grains are colorless to dark grey and display some cracks in inner domains. They range from 200 to $440 \mu \mathrm{m}$ and their $\mathrm{Th} / \mathrm{U}$ ratios range from 0.190 to 0.426 , indicating an igneous origin. The Concordia diagram for the analyzed zircon grains yields an upper intercept age of $2103.8 \pm 9.3 \mathrm{Ma}(\mathrm{MSWD}=1.8)$, which is interpreted as the protolith crystallization age (Figure 4.11).

Sample FL-60 is a pale gray inequigranular medium to coarse-grained metatonalite. This sample was collected in the central part of the Floresta Suite. Zircon 
grains from this sample are heterogeneous, subhedral, euhedral and anhedral and are 200 to $459 \mu \mathrm{m}$ long. They have well-developed igneous oscillatory zoning surrounded by discrete metamorphic overgrowth. They have $\mathrm{Th} / \mathrm{U}$ ratios ranging from 0.121 to 0.849. The Concordia diagram for this rock has a MSWD of 1.4, and the analyzed grains exhibit an upper intercept age of $2.098 \pm 18 \mathrm{Ma}$ (MSWD =1.4), which is interpreted as the age of crystallization of the protolith (Figure 4.12). FL-65 and FL-60 samples yield lower intercept ages of $492 \pm 46 \mathrm{Ma}$ and $457 \pm 57 \mathrm{Ma}$, respectively, which are interpreted as the result of $\mathrm{Pb}$ loss related to later thermal effects.

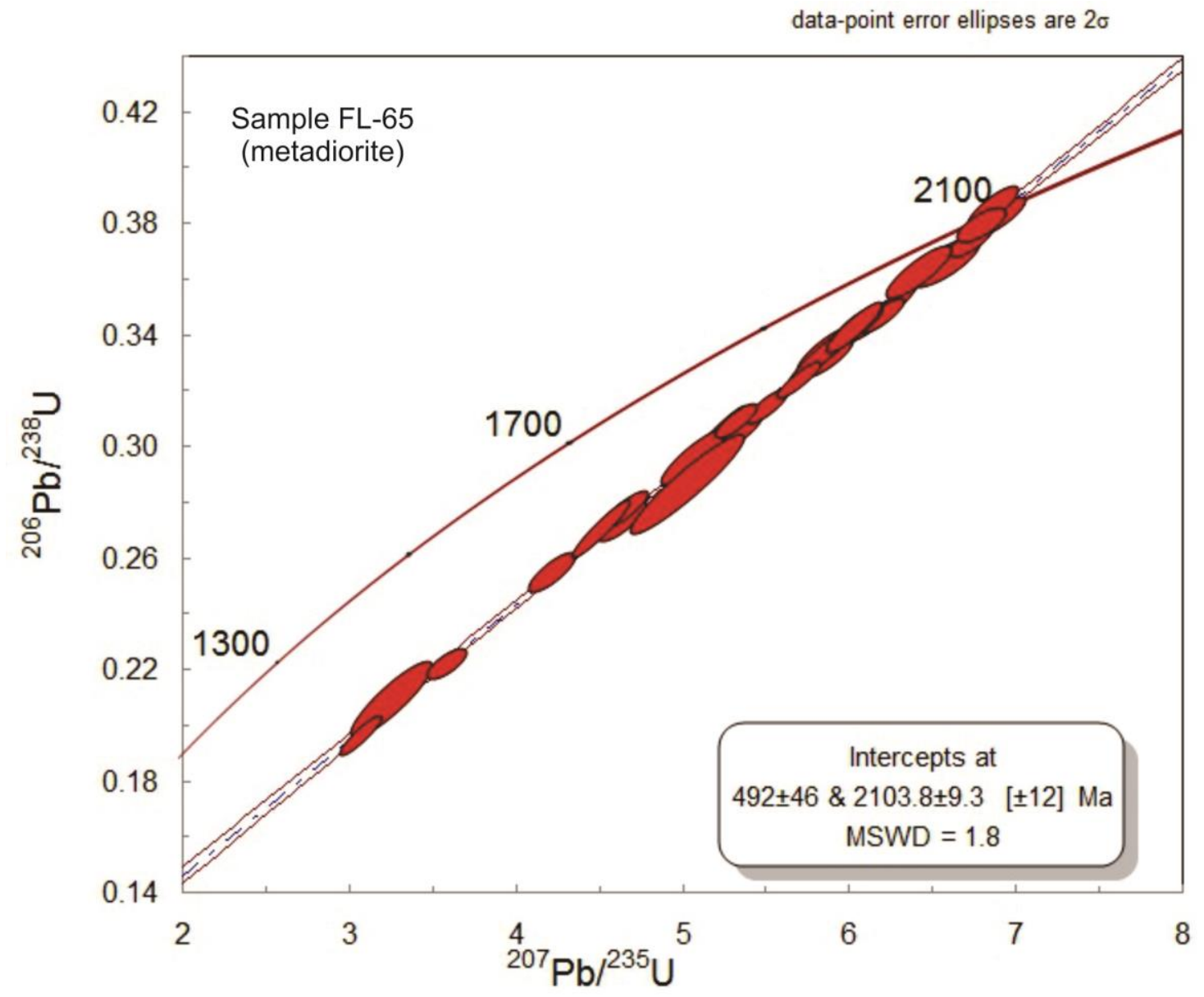

Figure 4.11 - U-Pb Concordia diagram for a metadiorite of the Floresta suite (sample FL-65). 


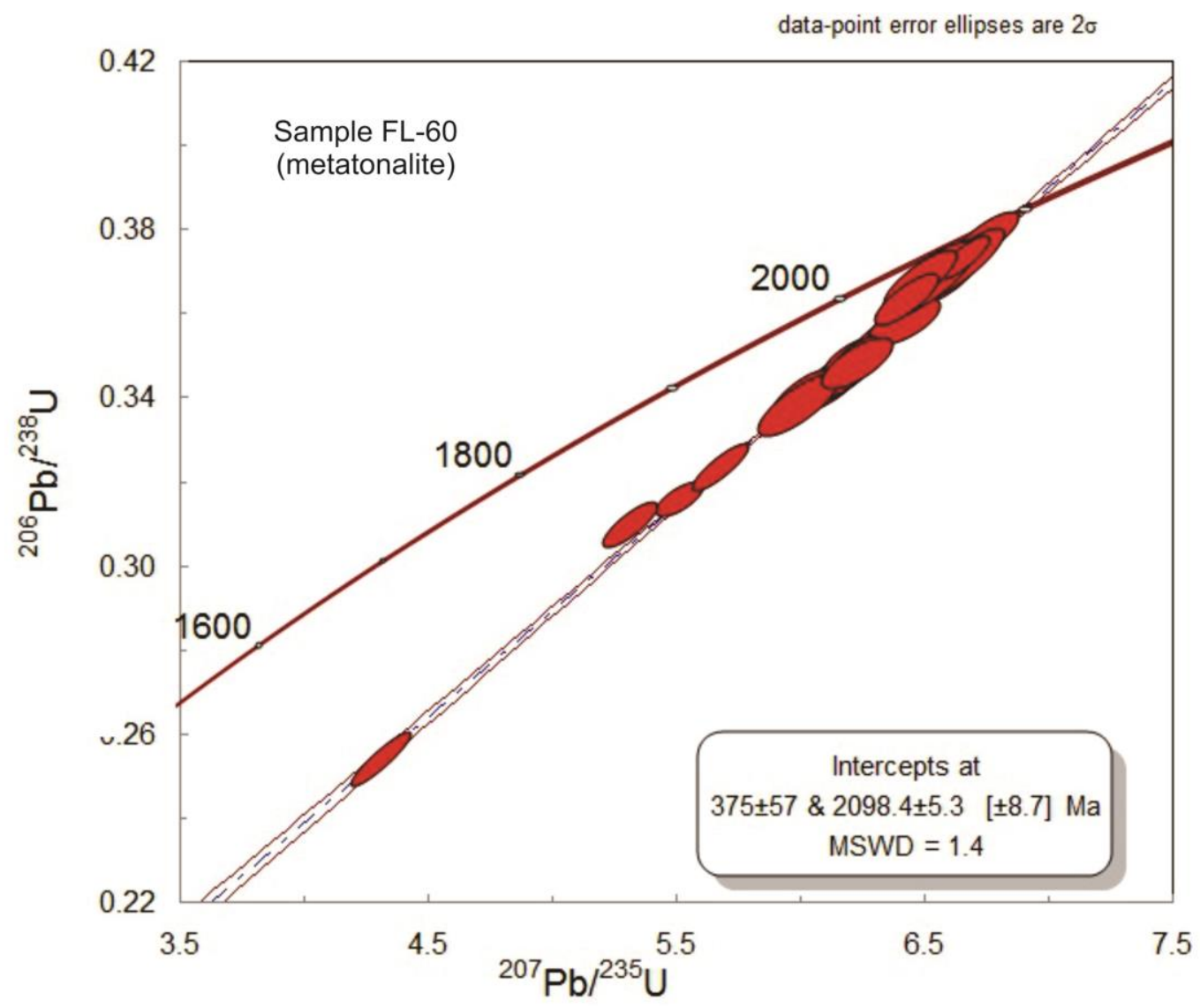

Figure 4.12 - U-Pb Concordia diagram for a metatonalite of the Floresta suite (sample FL-60).

\subsubsection{Sm-Nd Isotopes}

Sm-Nd isotope analyses were performed on seven representative samples of the Riacho das Lajes Suite and seventeen samples of the Floresta Suite. The corresponding isotopic compositions and isotopic ratios are presented in Table 4.7. Figure 4.13 shows the geographic distribution of the collected samples and the results. The obtained $\varepsilon \mathrm{Nd}$ (t) values were calculated using the 2.625 and $2.098 \mathrm{Ga}$ crystallization ages obtained for the Riacho das Lajes and Floresta suites, respectively (Figure 4.14). The samples from the Riacho das Lajes suite yielded Meso- to Neoarchean Nd depleted mantle ( $\mathrm{T}_{\mathrm{DM}}$ ) model ages ranging from 2.76 to $2.93 \mathrm{Ga}$ and a narrow range of slightly negative and positive $\varepsilon N d(t)$ values $(-2.35$ to +0.36$)$. The samples from the Floresta Suite present heterogeneous Archean to Paleoproterozoic $\mathrm{T}_{\mathrm{DM}}$ model ages $(3.19$ to $2.23 \mathrm{Ga})$. These 
data indicate the involvement of old crust in the genesis of these rocks. The $\varepsilon N d(t)$ values range from -12.03 to +4.47 .
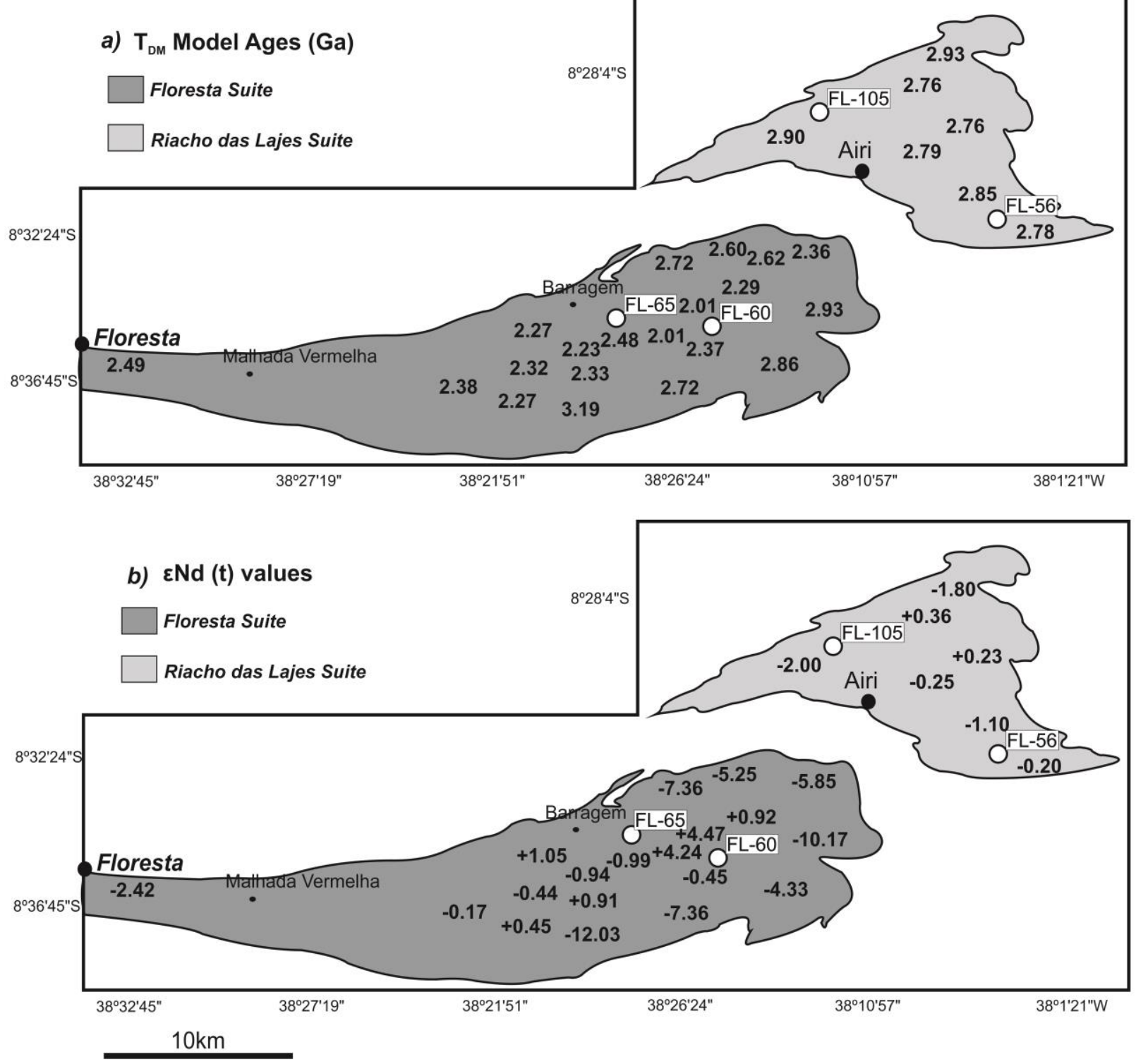

Figure 4.13 - Distribution of obtained Nd data along the Riacho das Lajes and Floresta Suites. The white circles represent the location of selected samples for U-Pb analysis. White circles represent the U-Pb dated samples. 
a)
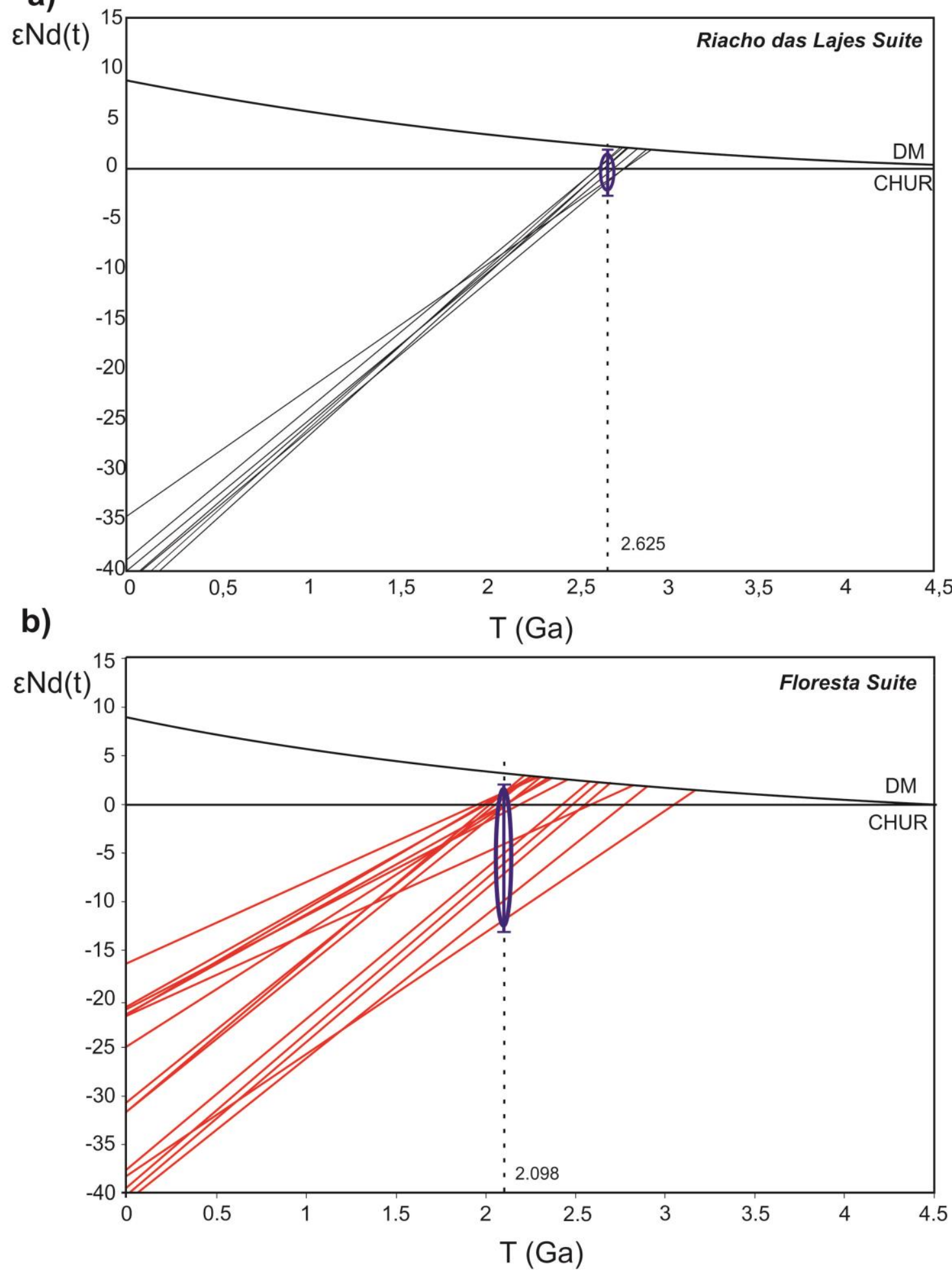

Figure 4.14 - Nd evolution diagram for the metaplutonic rocks of a) Riacho das Lajes and b) Floresta Suites. 


\subsection{Discussion}

\subsubsection{Magma sources and tectonic setting}

\subsubsection{Riacho das Lajes Suite}

Studied samples from the Riacho das Lajes Suite represent silicic, calcic, magnesian and slightly peraluminous magmas emplaced during the Neoarchean (ca. 2.6 $\mathrm{Ga}$ ). The primitive mantle-normalized spider diagram shows strong depletions of $\mathrm{Nb}$, $\mathrm{Ta}$ and $\mathrm{Ti}$, which can be interpreted as the effect of rutile, sphene or Ti-bearing amphibole as residual phases in the source region (Foley et al., 2000; Klemme et al., 2006). Such negative anomalies in spider diagrams are very distinctive of subductionrelated settings (Pearce, 1982). The chondrite-normalized REE diagram is characterized by the enrichment of light REE relative to heavy REE and exhibits positive Eu anomalies. Due to its high partition coefficient $(\mathrm{Kd})$, garnet is usually invoked as the main residual phase. This mineral concentrates most of HREE, thereby generating magmas with very low concentrations of Er, $\mathrm{Lu}, \mathrm{Tm}, \mathrm{Y}$ and $\mathrm{Yb}$, whereas Eu is easily accommodated in the plagioclase structure, and its high content suggests the enrichment of this phase in the melt.

General petrographic and geochemical data indicate that the Riacho das Lajes Suite samples have similar characteristics to classic Archean TTG or high-silica adakites. These include the i) dominant tonalite and granodiorite members, ii) high $\mathrm{SiO}_{2}$ (> 70\% wt.\%) and $\mathrm{Na} 2 \mathrm{O}(>4$ wt.\%), iii) low $\mathrm{MgO}(<1$ wt.\%) and $\mathrm{FeO}(<3$ wt.\%), iv) low $\mathrm{K}_{2} \mathrm{O} / \mathrm{Na}_{2} \mathrm{O}$ ratios $(<0.4)$, and $\mathrm{v}$ ) strongly fractionated REE pattern (Martin et al., 2005; Smithies and Champion, 2000; Condie, 2005; Castillo et al., 2006). However, they also display relatively high $\mathrm{K}_{2} \mathrm{O}$ contents (> 2 wt.\%) compared to classic Archean TTGs. This fact can be explained by the greater extent of fractional crystallization or remelting processes, which is fairly common in granitoid rocks related to the NeoarcheanPaleoproterozoic transition (Sylvester 1994; Moyen et al., 2003; Martin et al., 2010).

Experimental studies suggest that the main source region for the generation of Archean TTG is strongly controlled by Sr, Y and REE contents, once these elements are very pressure sensitive, therefore their concentrations in the melt depend on the depth and temperature conditions of partial melting (Moyen and Stevens, 2011; Moyen and 
Martin, 2012). On Sr/Y vs. Y (ppm), (Yb) $)_{\mathrm{N}}$ vs. $(\mathrm{La} / \mathrm{Yb})_{\mathrm{N}}$, and binary plots the Riacho das Lajes Suite samples represent TTG magmas derived from basaltic oceanic crust that likely experienced high pressure conditions (eclogitic source; Figures $4.15 \mathrm{a}$ and $4.15 \mathrm{~b}$ ). Moreover, the $(\mathrm{Gd} / \mathrm{Er})_{\mathrm{N}}$ vs. $\mathrm{MgO}$ binary plot also suggests a garnet-rich mafic source (Figure 4.15c).

Halla et al. (2009) divided the TTG series in two main groups: 1) high-HREE TTGs (low Al), which are related to a garnet-free source, and 2) low-HREE TTGs (high $\mathrm{Al}$ ), which are related to a garnet-bearing source. According to these authors, such contrasting sources can be attributed to two distinct pressure conditions (1.0 GPa for the first group and > 2.0 GPa for the second one). They also conclude that the involved physical conditions require that the precursor mafic source must be somehow introduced deep into the mantle. Most of the studied samples of Riacho das Lajes Suite are characterized by high $\mathrm{SiO}_{2}$ (> 70 wt.\%), $\mathrm{Al}_{2} \mathrm{O}_{3}(>14$ wt. $\%)$ and $\mathrm{Sr}(>350$ ppm) contents, in addition to low $\mathrm{MgO}(<1 \mathrm{wt} . \%)$ and HREE contents, which fits the High-Al low-HREE TTG group (Figure 4.15d). These features can be associated to highpressure and temperature conditions of partial melting of a garnet-rich basaltic (eclogitic) source as predicted by Moyen and Martin (2012) and Martin et al. (2014). Additionally, slightly negative and positive $\varepsilon N d(t)$ values suggest that these magmas experienced little contribution from the continental crust during their ascent.

Generation of TTG is generally related to the melting of oceanic crust or plateaus in subduction zones (Drummond and Defant 1990; Martin et al., 2005, 2014) but melting of an oceanic plateau above a mantle plume has also been proposed (Zegers and van Keken, 2001; Willbold et al., 2009). Intermediate scenarios involving interactions between subduction zones and upwelling mantle plumes have also been proposed (Johnson et al., 2013). Based on the data presented in this paper, we suggest that a deep intraoceanic hot subduction took place in the Neoarchean (ca. 2.6 Ga), probably underneath an oceanic plateau or protocrust as predicted by experimental studies (Halla et al., 2009; Moyen, 2011; Laurent et al., 2014). In addition, significant partial melting events resulted in a garnet-rich residuum and produced low-HREE TTG slab melts that generated the granitoid rocks of the Riacho das Lajes Suite (Figure 4.17a). 

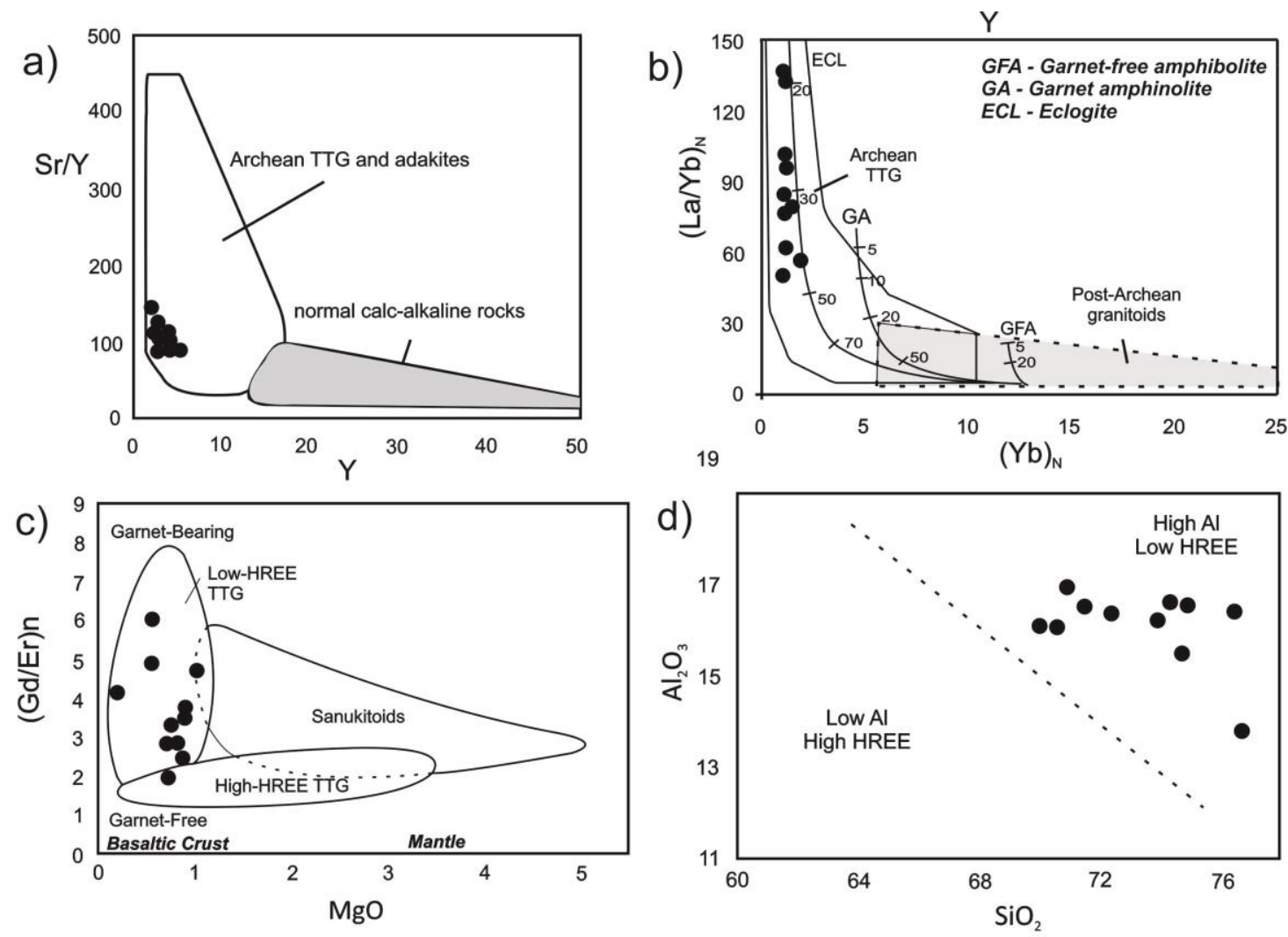

Figure 4.15 - Plots for the Riacho das Lajes Suite: a) Sr/Y diagram with fields of Archean TTG and adakites and normal calc-alkaline rocks from Drummond and Defant (1990) and b) (La/Yb)n vs. (Yb) $)_{\mathrm{N}}$ diagram. Fields of Archean TTG and post-Archean granitoids are from Martin (1986). Partial melting curves of eclogites, garnet amphibolites and amphibolites were calculated using the batch melting equation of Shaw (1970) and the partition coefficients compiled Rollinson (1993) and Nielsen (2007); c) (Gd/Er)n vs. MgO diagram with fields of low- to high HREE TTG and sanukitoids and hypothetic source end-members of garnet-bearing or garnet-free basaltic crust or mantle (high $\mathrm{MgO}$ ) from Halla et al. (2009); d) $\mathrm{Al}_{2} \mathrm{O}_{3}$ vs. $\mathrm{SiO}_{2}$ diagram separating low- and high HREE groups from Halla et al. (2009).

\subsubsection{Floresta Suite}

Chemically, metagranitoids and orthogneisses of the ca. 2.1 Ga Floresta Suite present a wide spectrum of $\mathrm{SiO}_{2}$ and $\mathrm{CaO}$ values that correspond to the calcic to calcalkalic series. In addition, they represent highly magnesian magmas with metaluminous to slightly peraluminous character. Samples are characterized by LILE enrichment and 
HFSE depletions, especially in $\mathrm{Nb}, \mathrm{P}$ and Ti elements. This pattern is generally related to the accumulation of Ti-rich phases (e.g., rutile, titanomagnetite and sphene). Furthermore, they exhibit moderate to high REE fractionation, which can be explained by the retention of HREE by garnet in the source region, similar to that in the Riacho das Lajes suite. Positive Eu peak is observed in most of the samples and is interpreted as resulting from the high concentration of this element in plagioclase during magma crystallization. Eu negative peaks are also present and reflect retention of this element by the same mineral during magma differentiation.

Such geochemical signature is typical of magmas generated in subductionrelated tectonic settings (Pearce and Peate, 1995; Tatsumi, 2005, Foley et al., 2000; Klemme et al., 2006). Magma generation can be explained by successive episodes of mantle wedge partial melting, which is metasomatized by fluids released from the subducted lithosphere (Tatsumi, 1989; Scmhidt et al., 2004; Li et al., 2009). Such arcrelated magma bodies rise rapidly to the crust where they undergo fractional crystallization (Sisson and Grove, 1993; Grove et al., 2003). The tectonic discriminant diagram of Pearce (1984, Figure 4.16a) also confirms the proposed tectonic setting, whereas major and trace element signature points out to an igneous high-K mafic source, with few contributions from metasedimentary deposits (Figure 4.16b).

However, some samples are characterized by high concentrations of $\mathrm{Ni}(>15$ ppm), $\mathrm{Cr}$ (>20 ppm) and V (> $100 \mathrm{ppm})$ as well as $\mathrm{Ba}$ (> $1000 \mathrm{ppm})$ and $\mathrm{Sr}$ (> 500 ppm). This particular enrichment of crustal- and mantle-related elements suggests that part of the rock samples from the Floresta Suite is chemically similar to the high-Mg dioritic magmas or sanukitoids (Shirey and Hanson 1984; Stern et al., 1989; Martin et al., 2005, 2010). Experimental studies indicate that such anomalous concentration of these elements rely on the interaction between mantle peridotite and melts enriched in incompatible elements (Halla et al., 2009; Heilimo et al., 2010; Oliveira et al., 2011; Laurent et al., 2014 Semprich et al., 2015). Hence, it seems that the source region for rocks of the Floresta Suite is strongly heterogeneous and the nature of each individual melting origin is still difficult to explain at this time. The mixing of sources is also reflected on high fluctuations of the $\varepsilon N d(t)$ values calculated for the $2.09 \mathrm{Ga}$ crystallization age. They range from positive to strongly negative, and thus reflect strong input of juvenile material as well as an important crustal component. Negative $\varepsilon N d(t)$ values also suggest an enriched source (Menzies et al., 1987), which can also be 
an explanation for the enrichment of unusual transition elements in subduction-related magmas (Halla et al., 2009; Laurent et al., 2014).

Any tectonic scenario for the generation of the Floresta Suite must geometrically associate the crust and metasomatized mantle. The most common tectonic setting for such rocks involves crustal thickening by terrane accretion, which is generally coeval with slab breakoff events, where the retreat of the slab and lithospheric delamination provide an important heat source (Halla et al., 2009; Laurent et al., 2014). Based on the obtained geochemical and isotopic data, we suggest that subduction took place at 2.1$2.0 \mathrm{Ga} \mathrm{Ga}$ and resulted in the emplacement of the Floresta Suite (Figure 4.17b). This hypothesis is consistent with the description of several accretion events in the region throughout the entire Rhyacian period (2.15 to 2.0 Ga, Santos et al., 2013; Santos et al., 2015a; Neves et al., 2015). 

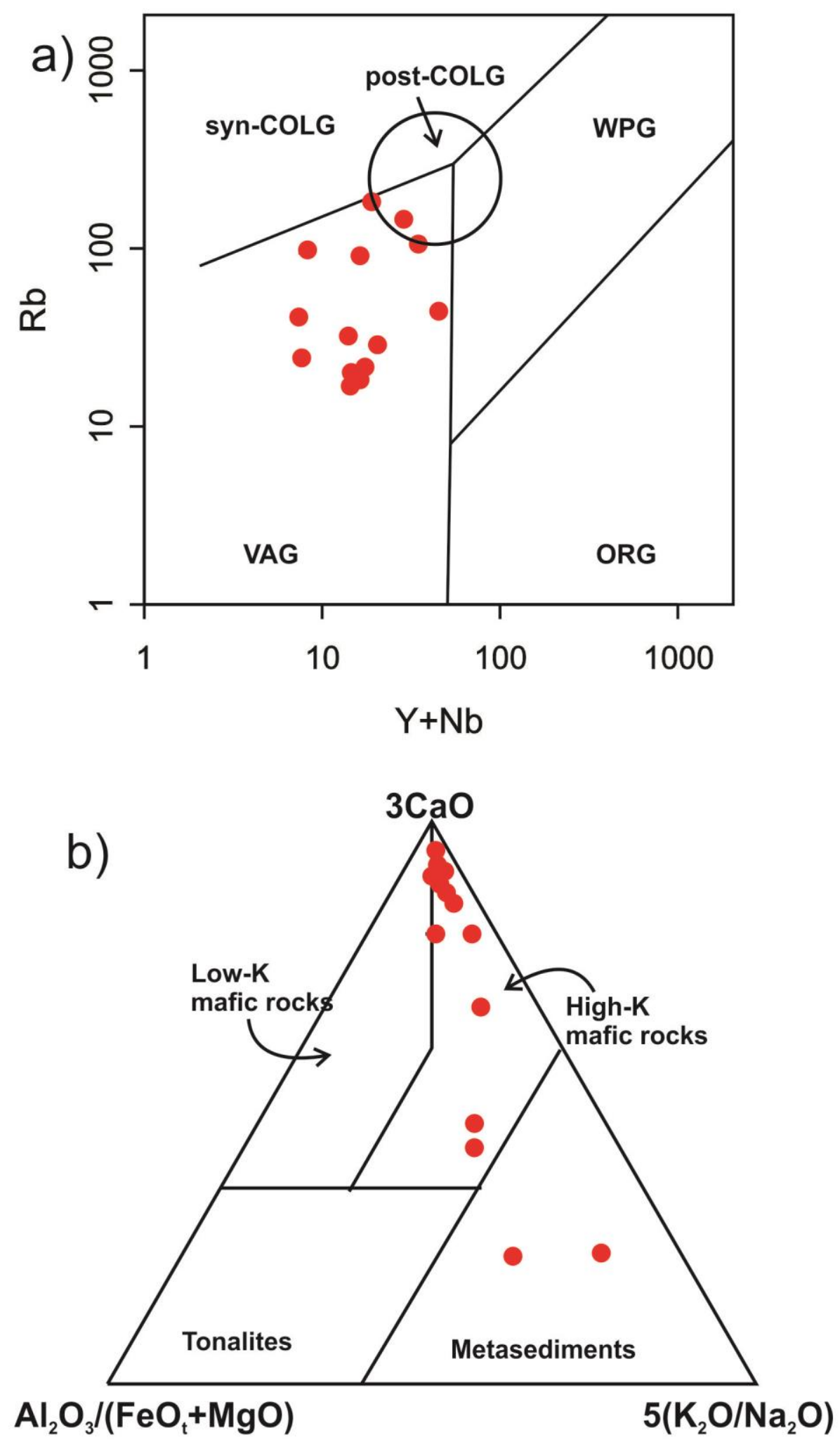

Figure 4.16 - Plots for the Floresta Suite: a) Discriminant tectonic diagram after Pearce et al. (1984); b) $\mathrm{Al}_{2} \mathrm{O}_{3} /(\mathrm{FeOt}+\mathrm{MgO})-3 \mathrm{CaO}-5\left(\mathrm{~K}_{2} \mathrm{O} / \mathrm{Na}_{2} \mathrm{O}\right)$ plot with fields after Laurent et al. (2014). 
a)

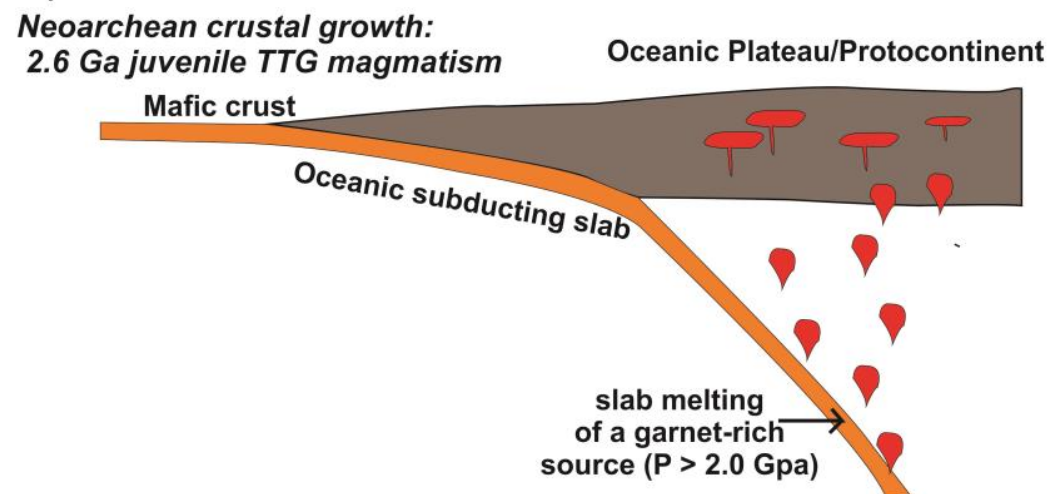

b)

Paleoproterozoic crustal reworking with slab breakoff:

$2.1 \mathrm{Ga}$ crustal reworking

source $(P>2.0 \mathrm{Gpa})$

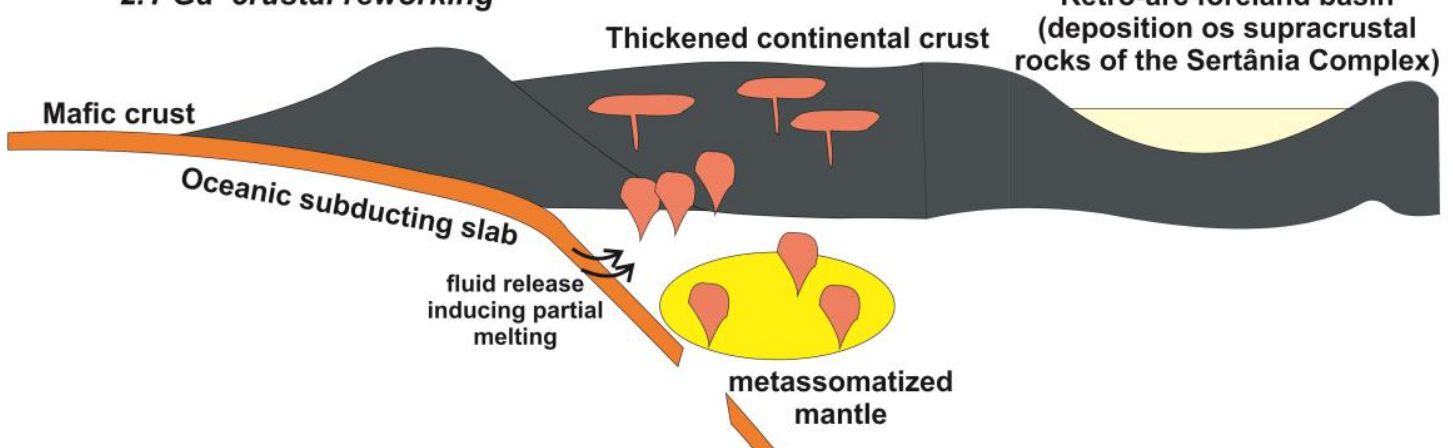

Figure 4.17 - Sketch tectonic model with suggested scenarios for Riacho das Lajes (a) and Floresta suite (b) magma emplacements.

4.6.2. Neoarchean crustal growth, Paleoproterozoic reworking and regional correlations

$\mathrm{U}-\mathrm{Pb}$ and $\mathrm{Sm}-\mathrm{Nd}$ data of the TTG rocks of the Riacho das Lajes Suite indicate juvenile magmatism with little crustal contamination at $2.6 \mathrm{Ga}$ in the Borborema Province. This is the first evidence of Archean crust in the Transversal sub province. These rocks present $\mathrm{T}_{\mathrm{DM}}$ model ages that are very close to the crystallization age and slightly negative to positive $\varepsilon \mathrm{Nd}(\mathrm{t})$ values. Therefore, they represent an important continental crustal growth event in the region, although some crustal contaminantion is recorded also. Dated samples from the Floresta Suite present Rhyacian crystallization ages $(2.1 \mathrm{Ga})$, and $\mathrm{Nd} \mathrm{T}_{\mathrm{DM}}$ model ages range from Archean to Paleoproterozoic, which suggests mixing of older and younger contributions in the source. These data indicate that crustal growth in the Rhyacian was coeval with reworking of the older Neoarchean 
crust, in addition to inferred mantle metasomatism. An important parameter related to the emplacement of rocks of the Floresta Suite is that negative $\varepsilon N d(t)$ values are concentrated in the rims of the intrusion, whereas positive values are present in its core. This strongly suggests that crustal contamination took place mostly in the peripheral region of the intrusion, triggered by country rocks.

It has been suggested that continental growth has been episodic throughout Earth's history, with main events marked by peaks at 3.3, 2.7, 1.9 and $1.2 \mathrm{Ga}$ (Condie and Kröner, 2013; Brown, 2009; Hawkesworth et al., 2010; Cawood et al., 2013). Moreover, in several cratonic blocks worldwide, the main growth episodes in the Archean took place at approximately $2.7 \mathrm{Ga}$ (Bleeker, 2003). However, although less frequently, juvenile TTGs dated at $2.6 \mathrm{Ga}$, such as for the Riacho das Lajes, have been documented in the Yilgarn Craton in West Australia (Griffin et al., 2004) and in the North China Craton in China (Wang and Liu, 2012), which suggests that subductionrelated events and crustal accretion continued until the Neoarchean-Paleoproterozoic transition, at least in some continental margins (Condie, 2000; Laurent et al., 2014).

Nevertheless, the recognition of such Archean and Paleoproterozoic crustal fragments within younger provinces, such as the Borborema Province, remains a difficult challenge, primarily because of the intense crustal reworking by younger tectonic events. Most of the Archean domains concentrated in the northern portion of the province are interpreted as part of ancient far-travelled terranes or basement inliers, such as the São José do Campestre Massif (Dantas et al., 2013), Tróia Massif (Costa et al., 2015) and Granjeiro Terrane (Delgado et al., 2003; Silva et al., 2014). Most of the Late Archean associations of these domains have ages in the 2.8-2.7 Ga interval and are a record of juvenile and reworked crust, such as the quartz-dioritic to syenogranitic rocks of the São José do Campestre Terrane and the orthogneisses and granitoids of the Cruzeta Complex of the Tróia Massif (Fetter et al., 2000).

Possible correlatives of the studied granitoids occur in neighboring cratons. For instance, Neoarchean crustal growth followed by Paleoproterozoic reworking has been documented in the juvenile and reworked mafic-ultramafic sequences, grey gneisses, migmatites and granitic rocks of the Serrinha and Jequié Blocks and Contendas Mirante Belt in the São Francisco Craton (Teixeira et al., 2000; Barbosa and Sabaté, 2005; Oliveira et al., 2011; Romano et al., 2013; Farina et al., 2015). Within the African 
continent, Neoarchean rocks are common in the granite-granulite terranes of the Kaapval and Zimbabwe cratons, as well as TTG rocks from the Limpopo Belt (de Wit et al., 1992; Goodwin, 1996; de Wit and Tinker, 2004; Krammers et al., 2006; Laurent et al., 2013; Tugume et al., 2013). Moreover, Paleoproterozoic belts are widespread in the African continent, formed during the long-lived Eburnean orogeny (Baratoux et al., 2011; Feybesse et al., 2006; Hein, 2010).

4.6.3. Tectonic evolution of the Alto Moxotó Terrane and implications for supercontinent reconstructions

Previous geodynamic hypotheses on the evolution of the Alto Moxotó Terrane did not consider tectonic events older than the Siderian (Santos et al., 2004; Santos et al., 2015a). However, several inherited zircon grains with ages around 2.7 to $2.6 \mathrm{Ga}$ and associated Archean $\mathrm{Nd} \mathrm{T}_{\mathrm{DM}}$ model ages of the Siderian and Rhyacian units strongly indicate the formation of older crust (Santos et al., 2015a). Nevertheless, available isotopic data concerning crustal events between 2.4 and $2.2 \mathrm{Ga}$ in the Alto Moxotó Terrane are rather scarce. The absence of data over this large time span hampers formulation of major geodynamic models or establishing accurate correlations. A synthesis of available isotopic data plus the results of this study is presented in Figure 4.18.

In the present study, we suggest that the evolution of the Alto Moxoto Terrane began with a subduction-related event in the Neoarchean (ca. 2.6 Ga), which involved the melting of oceanic basaltic crust in an intra-oceanic setting that produced the TTG magmas of the Riacho das Lajes Suite. Subsequently, this geodynamic scenario may have evolved to cratonized crust or microcontinent in the early Paleoproterozoic that may have been the source of several inherited Archean zircon grains found in other Paleoproterozoic units (Santos et al., 2015a). Between 2.2 and $2.0 \mathrm{Ga}$, arc accretion took place within a continental magmatic arc context and produced mafic-ultramafic tholeiitic magmas that evolved to calc-alkaline magmas (Santos et al., 2015b; Neves et al., 2015). In addition, we suggest that during Rhyacian subduction, slab break-off occurred at approximately $2.1 \mathrm{Ga}$, producing magmas to form the Floresta Suite. Peraluminous gneisses aged oat approximately $1.9 \mathrm{Ga}$ indicate a final continental 
collision closing this convergent cycle, which resulted in high-grade metamorphism (see Santos et al., 2015a and Neves et al., 2015 for details).

Several authors stated that most of cratonic fragments or microcontinents are missing in Paleoproterozoic supercontinent reconstructions, which may be represented by basement inliers or exotic terranes that occur within younger orogenic belts (e.g. Reddy and Evans, 2009; Bradley, 2011). In this sense, the recognition of old crustal segments, such as the Alto Moxotó Terrane within the Neoproterozoic Borborema Province, may provide useful information to understanding the evolution of Paleoproterozoic supercontinents such as Columbia and Atlantica (Rogers and Santosh 2004; Zhao et al., 2004).

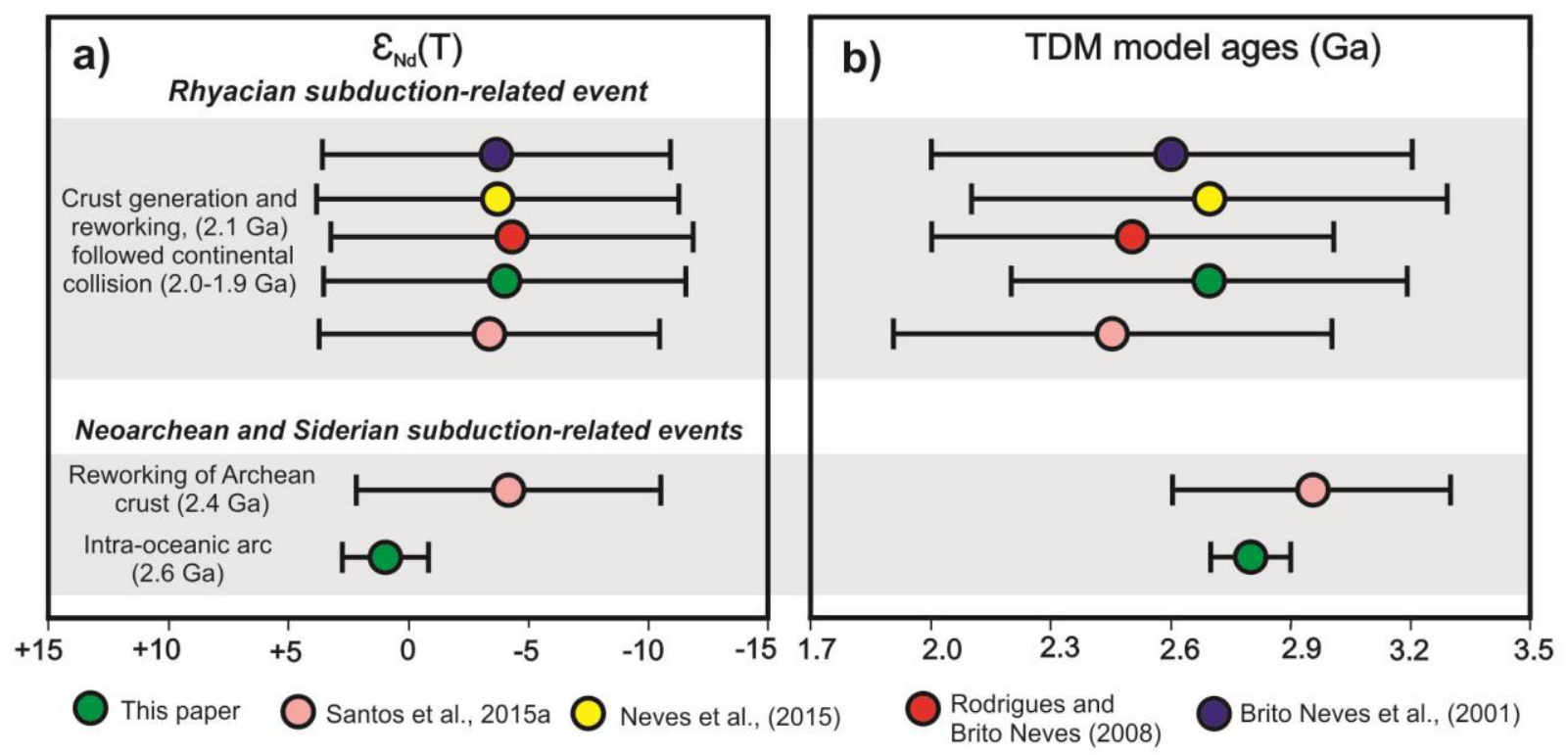

Figure 4.18 - Synthesis of obtained Nd data for rocks of the Alto Moxotó Terrane in the present and previous studies.

\subsection{Conclusions}

In the westernmost Alto Moxotó Terrane, Borborema Province, NE Brazil, we identified two distinct metaplutonic suites that represent important Neoarchean (ca. 2.6 $\mathrm{Ga}$ ) and Rhyacian (ca. 2.1 Ga) tectono-magmatic events. Emplacement of the high-Al low-REE TTG Riacho das Lajes Suite represents the former, which is the first record of Neoarchean rocks within the Transversal sub province of the Borborema Province. Its 
rock association was generated in a garnet-rich and fluid-absent source, which points to slab melting of oceanic crust metamorphosed under eclogite facies conditions. Nd isotopes clearly indicate a juvenile source with only minor crustal contamination. We interpret this event as the result of subduction beneath a thick oceanic plateau/protocrust.

Emplacement of the Floresta Suite tonalites, granodiorites and granites represents the Paleoproterozoic event (ca. $2.1 \mathrm{Ga}$ ). Geochemical parameters are compatible with subduction-related magmas. Combined trace-element geochemistry and isotopic data indicate a heterogeneous source, involving K-rich mafic rocks and minor contributions of metasedimentary deposits. Mantle metasomatism likely also took place. Heterogeneity is also reflected in the distribution of $\varepsilon N d(t)$ values, suggesting major involvement of country rocks, particularly in the rim zones of the intrusions, leading to infer juvenile magmatism and intense crustal reworking of Archean to Paleoproterozoic crust. We suggest that the Rhyacian accretion of terranes resulted in the emplacement of the Floresta magmas, coeval with slab breakoff. Slab retreat and lithospheric delamination provided the heat source. This interpretation is consistent with several subduction-related events suggested for this period in the Borborema Province.

Although the major Neoarchean crustal growth events have been dated at $2.7 \mathrm{Ga}$ in several provinces worldwide, magmatism extended until 2.6 and $2.5 \mathrm{Ga}$, as recorded in the Riacho das Lajes Suite of the Alto Moxotó Terrane. Accretion of Rhyacian magmatic was widespread in most Paleoproterozoic cratonic blocks, including the São Francisco-Congo Craton, where they are interpreted as being related to the Eburnean orogeny.

\subsection{Acknowledgements}

This paper is the outcome of the first author $\mathrm{PhD}$ thesis at Universidade de Brasília, Brazil. Authors are thankful to Universidade de Brasília geochronology lab staff. Esa Heilimo (Geological Survey of Finland) revised a previous manuscript version. ELD and RAF acknowledge CNPq financial support through INCT Estudos Tectônicos and research fellowships. 


\begin{tabular}{|c|c|c|c|c|c|c|c|c|c|c|c|}
\hline \multicolumn{11}{|c|}{ Major elements (wt.\%) } & FL 105 \\
\hline $\mathrm{Al}_{2} \mathrm{O}_{3}$ & 16.9 & 16.3 & 16.6 & 16.5 & 16.0 & 16.0 & 13.8 & 16.5 & 15.45 & 16.4 & 16.1 \\
\hline $\mathrm{CaO}$ & 3.22 & 2.95 & 3.17 & 3.3 & 3.39 & 3.16 & 2.86 & 3.09 & 2.54 & 2.75 & 3.07 \\
\hline $\mathrm{Fe}_{2} \mathrm{O}_{3}$ & 3.69 & 3.20 & 2.8 & 2.78 & 3.11 & 2.97 & 1.04 & 3.16 & 2.12 & 2.64 & 2.98 \\
\hline $\mathrm{Cr}_{2} \mathrm{O}_{3}$ & 0.02 & 0.02 & 0.02 & 0.02 & 0.01 & 0.02 & 0.01 & 0.01 & 0.01 & 0.01 & 0.01 \\
\hline $\mathrm{K}_{2} \mathrm{O}$ & 2.69 & 2.89 & 2.36 & 2.17 & 1.88 & 2.05 & 0.83 & 2.75 & 4.23 & 3.35 & 2.87 \\
\hline $\mathrm{MgO}$ & 1.02 & 0.84 & 0.8 & 0.71 & 0.78 & 0.73 & 0.15 & 0.88 & 0.53 & 0.54 & 0.86 \\
\hline $\mathrm{MnO}$ & 0.04 & 0.03 & 0.03 & 0.03 & 0.03 & 0.03 & 0.02 & 0.03 & 0.02 & 0.03 & 0.03 \\
\hline $\mathrm{Na}_{2} \mathrm{O}$ & 4.85 & 4.67 & 5.0 & 5.07 & 4.76 & 4.82 & 4.43 & 4.76 & 3.98 & 4.79 & 4.61 \\
\hline $\mathrm{P}_{2} \mathrm{O}_{5}$ & 0.18 & 0.15 & 0.15 & 0.19 & 0.13 & 0.15 & 0.03 & 0.23 & 0.08 & 0.15 & 0.13 \\
\hline $\mathrm{SiO}_{2}$ & 70.8 & 72.4 & 74.3 & 74.8 & 70.5 & 69.8 & 76.7 & 71.3 & 74.7 & 76.4 & 73.9 \\
\hline $\mathrm{TiO}_{2}$ & 0.44 & 0.37 & 0.34 & 0.31 & 0.35 & 0.32 & 0.07 & 0.35 & 0.2 & 0.25 & 0.34 \\
\hline LOI & 0.82 & 0.61 & 0.47 & 0.45 & 0.42 & 0.54 & 0.24 & 0.37 & 0.40 & 0.24 & 0.37 \\
\hline Total & 102.0 & 102.2 & 102.1 & 101.9 & 101.5 & 100.64 & 100.2 & 103.0 & 102.0 & 102.8 & 102.3 \\
\hline \multicolumn{12}{|c|}{ Trace elements (ppm) } \\
\hline $\mathrm{Ba}$ & 802 & 946 & 733 & 659 & 570 & 631 & 460 & 746 & 1190 & 911 & 796 \\
\hline $\mathrm{Ce}$ & 118 & 56.4 & 46.4 & 46.5 & 54.3 & 25.1 & 44.1 & 74.2 & 51.1 & 73.6 & 53.5 \\
\hline $\mathrm{Cr}$ & 140 & 150 & 160 & 160 & 110 & 140 & 70.0 & 70.0 & 60.0 & 60.0 & 70.0 \\
\hline Cs & 1.49 & 1.33 & 1.21 & 1.09 & 1.22 & 1.13 & 0.44 & 0.94 & 0.5 & 1.21 & 1.14 \\
\hline Dy & 0.78 & 0.63 & 0.66 & 0.59 & 0.67 & 0.46 & 0.87 & 0.67 & 0.71 & 0.85 & 0.61 \\
\hline $\mathrm{Er}$ & 0.33 & 0.32 & 0.28 & 0.32 & 0.33 & 0.33 & 0.26 & 0.29 & 0.21 & 0.19 & 0.25 \\
\hline $\mathrm{Eu}$ & 0.99 & 0.78 & 0.84 & 0.77 & 0.87 & 0.68 & 0.97 & 0.89 & 0.75 & 0.74 & 0.77 \\
\hline $\mathrm{Ga}$ & 20.4 & 19.8 & 20.2 & 19.8 & 20.3 & 20.7 & 12.0 & 19.7 & 16.9 & 17.4 & 18.8 \\
\hline $\mathrm{Gd}$ & 1.89 & 0.98 & 1.16 & 1.11 & 1.17 & 0.81 & 1.3 & 1.31 & 1.23 & 1.4 & 1.06 \\
\hline $\mathrm{Hf}$ & 6.9 & 6.7 & 5.3 & 5.7 & 6.3 & 5.6 & 1.8 & 4.8 & 3.2 & 4.4 & 5.2 \\
\hline Ho & 0.14 & 0.1 & 0.13 & 0.12 & 0.12 & 0.08 & 0.12 & 0.11 & 0.12 & 0.12 & 0.11 \\
\hline $\mathrm{La}$ & 80.1 & 41.4 & 31.9 & 32.0 & 37.1 & 18.0 & 22.8 & 49.1 & 33.2 & 50.1 & 37.7 \\
\hline
\end{tabular}




\begin{tabular}{|c|c|c|c|c|c|c|c|c|c|c|c|}
\hline $\mathrm{Lu}$ & 0.03 & 0.04 & 0.04 & 0.02 & 0.03 & 0.04 & 0.01 & 0.02 & 0.03 & 0.03 & 0.02 \\
\hline $\mathrm{Nb}$ & 8.4 & 6.9 & 6.0 & 9.6 & 6.5 & 6.4 & 1.4 & 5.6 & 4.2 & 4.4 & 5.8 \\
\hline $\mathrm{Nd}$ & 32.6 & 17.4 & 12.8 & 14.0 & 16.3 & 7.7 & 16.2 & 21.6 & 15.6 & 22.0 & 15.1 \\
\hline $\operatorname{Pr}$ & 11.0 & 5.63 & 4.3 & 4.28 & 5.11 & 2.31 & 4.65 & 6.99 & 4.95 & 7.09 & 4.91 \\
\hline $\mathrm{Rb}$ & 75.1 & 69.9 & 61.9 & 56.7 & 58.5 & 56.0 & 16.1 & 77.9 & 82.8 & 84.0 & 76.6 \\
\hline $\mathrm{Sm}$ & 3.44 & 1.97 & 1.73 & 1.71 & 1.95 & 1.21 & 2.28 & 2.26 & 1.94 & 2.77 & 1.82 \\
\hline $\mathrm{Sn}$ & 1.00 & 1.00 & 1.00 & 1.00 & 1.00 & n.d. & n.d & 1.00 & n.d. & 1.00 & n.d \\
\hline $\mathrm{Sr}$ & 311 & 304 & 312 & 316 & 311 & 296 & 352 & 308 & 263 & 294 & 295 \\
\hline $\mathrm{Ta}$ & 10.4 & 2.41 & 2.60 & 2.12 & 2.03 & 8.00 & 0.38 & 0.48 & 0.46 & 0.39 & 0.50 \\
\hline $\mathrm{Tb}$ & 0.22 & 0.12 & 0.12 & 0.09 & 0.15 & 0.09 & 0.22 & 0.18 & 0.14 & 0.18 & 0.12 \\
\hline Th & 16.6 & 7.73 & 5.74 & 6.25 & 7.63 & 2.35 & 3.87 & 9.55 & 6.36 & 17.25 & 6.34 \\
\hline $\mathrm{Tm}$ & 0.04 & 0.02 & 0.03 & 0.02 & 0.05 & 0.04 & 0.03 & 0.03 & 0.04 & 0.02 & 0.02 \\
\hline $\mathrm{U}$ & 0.83 & 0.82 & 0.61 & 0.66 & 0.72 & 0.53 & 0.52 & 0.62 & 0.43 & 2.07 & 0.62 \\
\hline V & 32.0 & 31.0 & 27.0 & 25.0 & 26.0 & 25.0 & 7.0 & 31.0 & 14.0 & 17.0 & 27.0 \\
\hline W & 12.0 & 9.0 & 11.0 & 10.0 & 8.0 & 8.0 & 3.0 & 3.0 & 3.0 & 5.0 & 3.0 \\
\hline Y & 3.6 & 3.0 & 3.0 & 3.0 & 3.3 & 2.1 & 3.3 & 2.6 & 3.1 & 2.9 & 2.7 \\
\hline $\mathrm{Yb}$ & 0.31 & 0.29 & 0.27 & 0.26 & 0.31 & 0.22 & 0.25 & 0.24 & 0.38 & 0.25 & 0.25 \\
\hline $\mathrm{Zr}$ & 278.0 & 268.0 & 212.0 & 228.0 & 261.0 & 229.0 & 59.0 & 193.0 & 125.0 & 170.0 & 205.0 \\
\hline
\end{tabular}

Table 4.1 - Major (wt. \%) and trace element (ppm) concentrations of the Riacho das Lajes Suite, Alto Moxotó Terrane, NE Brazil. 
Sample

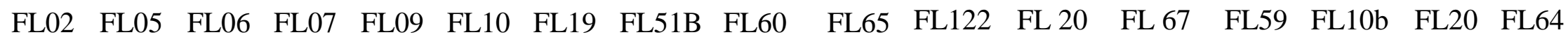

Major elements

(wt.\%)

\begin{tabular}{|c|c|c|c|c|c|c|c|c|c|c|c|c|c|c|c|c|c|}
\hline & 13.1 & 18.9 & 18.6 & 19.9 & 20.8 & 15.0 & 18.1 & 15.7 & 17.1 & 18.5 & 13.0 & 13.5 & 16.9 & 14.9 & 17.2 & 17.1 & 18.1 \\
\hline $\mathrm{O}$ & 1.94 & 7.52 & 7.41 & 8.17 & 8.83 & 3.76 & 6.79 & 2.35 & 6.39 & 6.61 & 1.15 & 1.32 & 6.04 & 4.51 & 6.56 & 6.53 & 8.46 \\
\hline${ }_{2} \mathrm{O}_{3}$ & 2.43 & 7.63 & 7.8 & 8.41 & 10.7 & 3.96 & 7.98 & 1.99 & 7.49 & 7.10 & 1.62 & 3.07 & 7.89 & 3.36 & 6.59 & 5.95 & 9.49 \\
\hline $\mathrm{K}_{2} \mathrm{O}$ & 3.12 & 0.89 & 0.87 & 0.92 & 1.18 & 1.00 & 1.04 & 4.63 & 2.79 & 0.74 & 4.43 & 5.49 & 1.49 & 3.02 & 0.71 & 0.68 & 0.82 \\
\hline $\mathrm{MgO}$ & 0.44 & 3.57 & 3.52 & 4.02 & 5.22 & 1.02 & 3.41 & 0.41 & 4.13 & 3.28 & 0.23 & 0.52 & 3.41 & 1.91 & 3.19 & 3.08 & 4.69 \\
\hline $\mathrm{InO}$ & 0.05 & 0.13 & 0.13 & 0.13 & 0.19 & 0.05 & 0.12 & 0.02 & 0.12 & 0.13 & 0.02 & 0.06 & 0.17 & 0.06 & 0.14 & 0.13 & 0.16 \\
\hline $\mathrm{Na}_{2} \mathrm{O}$ & 3.66 & 4.09 & 3.99 & 4.07 & 4.06 & 4.22 & 4.01 & 3.95 & 3.63 & 4.09 & 2.91 & 2.52 & 3.55 & 3.14 & 3.61 & 3.60 & 3.53 \\
\hline $\mathrm{P}_{2} \mathrm{O}_{5}$ & 0.09 & 0.24 & 0.22 & 0.23 & 0.31 & 0.17 & 0.2 & 0.13 & 0.38 & 0.21 & 0.20 & 0.18 & 0.27 & 0.16 & 0.22 & 0.22 & 0.08 \\
\hline $\mathrm{SiO}_{2}$ & 74.4 & 59.8 & 58.4 & 56.4 & 52.5 & 71.1 & 60.4 & 76.2 & 59.2 & 63.8 & 76.71 & 73.50 & 59.9 & 69.5 & 61.4 & 61.3 & 53.1 \\
\hline $\mathrm{TiO}_{2}$ & 0.23 & 0.66 & 0.66 & 0.73 & 0.91 & 0.47 & 0.57 & 0.21 & 0.78 & 0.63 & 0.19 & 0.33 & 0.80 & 0.39 & 0.60 & 0.58 & 0.84 \\
\hline LOI & 0.31 & 0.50 & 0.52 & 0.23 & 0.46 & 0.13 & 0.56 & 0.24 & 0.43 & 0.64 & 0.63 & 0.54 & 0.76 & 0.70 & 0.72 & 0.67 & 0.56 \\
\hline $\begin{array}{l}\text { Total } \\
\text { Trace elements } \\
\text { (ppm) }\end{array}$ & 100.0 & 102.0 & 102.9 & 0.46 & 102.0 & 101.1 & 100.0 & 102.1 & 102.0 & 102.0 & 101.1 & 100.7 & 101.3 & 101.9 & 101.1 & 100.0 & 100.2 \\
\hline $\mathrm{Ba}$ & 1345 & 460 & 473 & 432 & 507 & 746 & 427 & 1545 & 948 & 545 & 418 & 546 & 1290 & 1660 & 641 & 763 & 542 \\
\hline & 41.3 & 31.6 & 34 & 28.7 & 33.3 & 19.4 & 21.8 & 59 & 125 & 30.3 & 104.5 & 106.5 & 49.8 & 63.8 & 34.0 & 33.7 & 34.6 \\
\hline
\end{tabular}




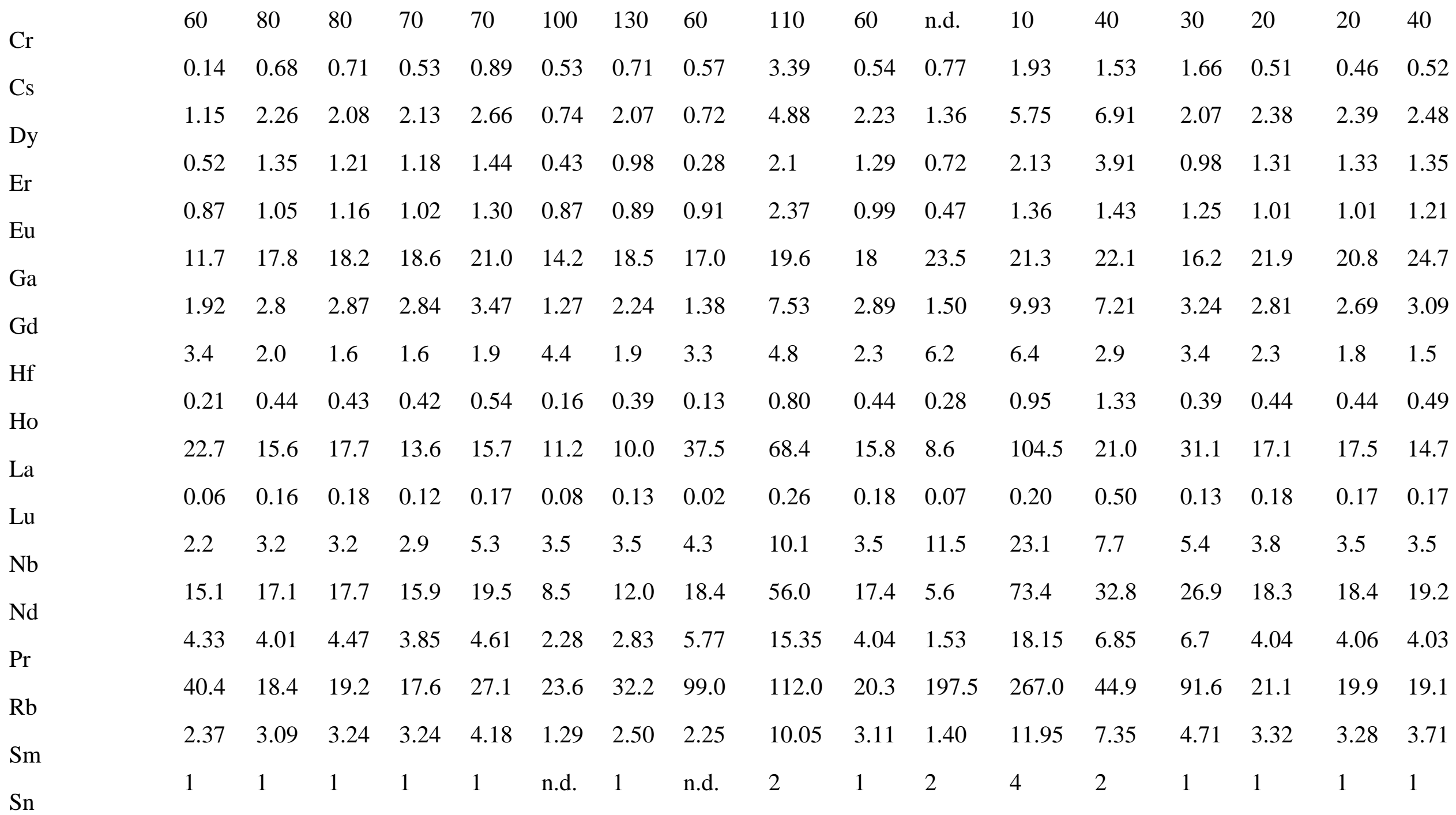




$\begin{array}{lllllllllllllllllll}\mathrm{Sr} & 213 & 775 & 795 & 841 & 833 & 555 & 721 & 290 & 828 & 768 & 96.1 & 119 & 435 & 834 & 747 & 740 & 745 \\ \mathrm{Ta} & 0.21 & 0.40 & 0.45 & 0.33 & 0.61 & 0.52 & 0.52 & 0.44 & 0.51 & 0.43 & 0.78 & 0.91 & 0.49 & 1.02 & 0.45 & 0.42 & 0.48 \\ \mathrm{~Tb} & 0.18 & 0.4 & 0.41 & 0.36 & 0.51 & 0.16 & 0.33 & 0.14 & 0.93 & 0.40 & 0.26 & 1.18 & 1.05 & 0.40 & 0.39 & 0.40 & 0.45 \\ \mathrm{Th} & 4.01 & 1.59 & 1.66 & 0.65 & 1.46 & 1.89 & 1.78 & 12.75 & 17.9 & 0.86 & 80.0 & 19.35 & 0.76 & 9.88 & 0.54 & 0.63 & 0.97 \\ \mathrm{Tm} & 0.07 & 0.15 & 0.18 & 0.17 & 0.22 & 0.06 & 0.16 & 0.0 .03 & 0.34 & 0.18 & 0.11 & 0.26 & 0.54 & 0.14 & 0.20 & 0.21 & 0.19 \\ \mathrm{U} & 0.2 & 0.23 & 0.29 & 0.31 & 0.3 & 0.3 & 0.21 & 1.07 & 1.29 & 0.25 & 3.15 & 16.35 & 0.19 & 0.70 & 0.24 & 0.25 & 0.26 \\ \mathrm{~V} & 21 & 160 & 167 & 174 & 217 & 47 & 163 & 13 & 168 & 153 & 13 & 19 & 138 & 77 & 138 & 129 & 211 \\ \mathrm{~W} & 4 & 4 & 3 & 7 & 2 & 5 & 3 & 3 & 3 & 2 & 76 & 14 & 49 & 37 & 97 & 11 & 5 \\ \mathrm{Y} & 5.1 & 11.9 & 12.3 & 11 & 14.7 & 4.1 & 10.3 & 3.2 & 23.7 & 12.6 & 7.1 & 30.6 & 37.4 & 10.5 & 13.5 & 13.5 & 13.5 \\ \mathrm{Yb} & 0.5 & 1.17 & 1.26 & 1.11 & 1.48 & 0.41 & 1.01 & 0.23 & 1.74 & 1.19 & 0.53 & 1.47 & 3.38 & 0.98 & 1.25 & 1.21 & 1.20 \\ \mathrm{Zr} & 126 & 77 & 62 & 63 & 78 & 178 & 74 & 132 & 183 & 91 & 199 & 220 & 107 & 128 & 86 & 67 & 51\end{array}$

Table 4.2 - Major (wt. \%) and trace element (ppm) concentrations of the Floresta Suite, Alto Moxotó Terrane, NE Brazil. n.d. = not detected. 


\section{Isotopic}

ratios

\begin{tabular}{|c|c|c|c|c|c|c|c|c|c|c|c|c|c|c|c|}
\hline & ratios & & & & & & Ages & & & & & & & & \\
\hline $\begin{array}{l}\text { Grain } \\
\text { spot }\end{array}$ & ${ }^{207} \mathrm{~Pb} /{ }^{206} \mathrm{~Pb}$ & $\pm(1 \sigma)$ & ${ }^{207} \mathrm{~Pb} /{ }^{235} \mathrm{U}$ & $\pm(1 \sigma)$ & ${ }^{206} \mathrm{~Pb} /{ }^{238} \mathrm{U}$ & $\begin{array}{l} \pm \\
(1 \sigma)\end{array}$ & ${ }^{207} \mathrm{~Pb} /{ }^{206} \mathrm{~Pb}$ & $\pm(1 \sigma)$ & ${ }^{207} \mathrm{~Pb} /{ }^{235} \mathrm{U}$ & $\pm(1 \sigma)$ & ${ }^{206} \mathrm{~Pb} /{ }^{238} \mathrm{U}$ & $\pm(1 \sigma)$ & Rho & $\mathrm{Th} / \mathrm{U}$ & $\begin{array}{l}\text { Conc. } \\
(\%)\end{array}$ \\
\hline $\mathrm{Z7N}$ & 0.17 & 0.51 & 10.05 & 0.95 & 0.42 & 0.81 & 2541.90 & 8.84 & 2439.75 & 8.81 & 2264.08 & 15.37 & 0.82 & 0.34 & 92.80 \\
\hline Z7B & 0.17 & 0.42 & 9.58 & 0.97 & 0.40 & 0.88 & 2528.10 & 7.29 & 2394.90 & 8.96 & 2187.97 & 16.29 & 0.89 & 0.28 & 91.36 \\
\hline $\mathrm{Z} 8$ & 0.11 & 0.95 & 2.15 & 1.65 & 0.14 & 1.35 & 1759.20 & 17.32 & 1163.78 & 11.36 & 847.93 & 10.69 & 0.82 & 0.30 & 72.86 \\
\hline Z9 & 0.15 & 0.55 & 5.24 & 1.13 & 0.25 & 0.98 & 2301.07 & 9.67 & 1859.24 & 9.60 & 1452.83 & 12.80 & 0.86 & 0.46 & 8.14 \\
\hline $\mathrm{Z} 10$ & 0.15 & 0.43 & 6.10 & 0.88 & 0.29 & 0.77 & 2351.98 & 7.60 & 1990.24 & 7.72 & 1619.64 & 11.06 & 0.85 & 0.14 & 81.38 \\
\hline Z13 & 0.16 & 0.54 & 7.80 & 1.08 & 0.35 & 0.94 & 2441.53 & 9.42 & 2208.00 & 9.76 & 1917.48 & 15.60 & 0.85 & 0.10 & 86.84 \\
\hline $\mathrm{Z} 15$ & 0.16 & 0.50 & 7.32 & 1.10 & 0.32 & 0.97 & 2448.32 & 8.78 & 2151.18 & 9.79 & 1808.49 & 15.35 & 0.88 & 0.36 & 84.07 \\
\hline Z16 & 0.17 & 0.73 & 9.15 & 1.20 & 0.39 & 0.95 & 2517.25 & 12.70 & 2353.60 & 11.03 & 2117.40 & 17.23 & 0.78 & 0.21 & 89.96 \\
\hline $\mathrm{Z} 17$ & 0.16 & 0.58 & 8.61 & 1.06 & 0.38 & 0.89 & 2454.79 & 10.06 & 2297.77 & 9.65 & 2074.25 & 15.76 & 0.82 & 0.21 & 90.27 \\
\hline $\mathrm{Z} 20$ & 0.17 & 0.80 & 8.80 & 1.33 & 0.38 & 1.07 & 2487.71 & 13.83 & 2317.30 & 12.16 & 2077.69 & 18.98 & 0.79 & 0.23 & 89.66 \\
\hline $\mathrm{Z} 21$ & 0.17 & 0.88 & 8.95 & 1.38 & 0.38 & 1.06 & 2497.68 & 15.29 & 2332.43 & 12.56 & 2096.71 & 18.89 & 0.75 & 0.31 & 89.89 \\
\hline $\mathrm{Z} 22$ & 0.17 & 0.46 & 8.35 & 1.05 & 0.36 & 0.94 & 2499.71 & 8.01 & 2269.58 & 9.52 & 1974.08 & 16.02 & 0.89 & 0.26 & 86.98 \\
\hline $\mathrm{Z} 25$ & 0.08 & 1.31 & 1.08 & 1.94 & 0.10 & 1.43 & 1021.96 & 26.30 & 743.06 & 10.17 & 636.39 & 8.66 & 0.76 & 0.32 & 85.64 \\
\hline $\mathrm{Z} 31$ & 0.17 & 0.52 & 10.43 & 0.84 & 0.43 & 0.66 & 2550.09 & 8.98 & 2473.74 & 7.82 & 2325.60 & 12.98 & 0.75 & 0.40 & 94.01 \\
\hline 32 & 0.17 & 0.80 & 9.01 & 1.14 & 0.39 & 0.81 & 2485.13 & 13.92 & 2338.84 & 10.44 & 2122.72 & 14.70 & 0.68 & 0.30 & 0.76 \\
\hline 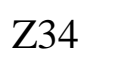 & 0.17 & 0.57 & 9.06 & 0.99 & 0.39 & 0.81 & 2493.80 & 9.91 & 2344.22 & 9.07 & 2124.06 & 14.66 & 0.79 & 0.25 & 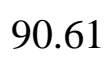 \\
\hline
\end{tabular}

Table 4.3 - Summary of LA-ICP-MS data of zircons from sample LS-56 (Riacho das Lajes Suite). 


\section{Isotopic}

ratios

\begin{tabular}{|c|c|c|c|c|c|c|c|c|c|c|c|c|c|c|c|}
\hline $\begin{array}{l}\text { Grain } \\
\text { spot }\end{array}$ & $\begin{array}{c}\text { ratios } \\
{ }^{207} \mathrm{~Pb} /{ }^{206} \mathrm{~Pb}\end{array}$ & $\pm(1 \sigma)$ & ${ }^{207} \mathrm{~Pb} /{ }^{235} \mathrm{U}$ & $\pm(1 \sigma)$ & ${ }^{206} \mathrm{~Pb} /{ }^{238} \mathrm{U}$ & $\begin{array}{l} \pm \\
(1 \sigma)\end{array}$ & ${ }^{207} \mathrm{~Pb} /{ }^{206} \mathrm{~Pb}$ & $\pm(1 \sigma)$ & ${ }^{207} \mathrm{~Pb} /{ }^{235} \mathrm{U}$ & $\pm(1 \sigma)$ & ${ }^{206} \mathrm{~Pb} /{ }^{238} \mathrm{U}$ & $\pm(1 \sigma)$ & Rho & $\mathrm{Th} / \mathrm{U}$ & $\begin{array}{l}\text { Conc. } \\
(\%)\end{array}$ \\
\hline Z16 & 0.16 & 0.52 & 6.51 & 1.48 & 0.30 & 1.39 & 2375.27 & 8.77 & 2047.38 & 12.94 & 1694.98 & 20.62 & 0.94 & 0.13 & 82.79 \\
\hline $\mathrm{Z} 52$ & 0.16 & 0.92 & 7.00 & 1.67 & 0.32 & 1.39 & 2380.10 & 16.10 & 2110.85 & 14.82 & 1800.48 & 21.88 & 0.83 & 0.05 & 85.30 \\
\hline $\mathrm{Z6N}$ & 0.16 & 0.42 & 7.28 & 1.80 & 0.33 & 1.75 & 2414.84 & 7.26 & 2146.17 & 16.05 & 1830.91 & 27.88 & 0.97 & 0.23 & 85.31 \\
\hline $\mathrm{Z} 50$ & 0.16 & 1.70 & 7.11 & 2.24 & 0.32 & 1.46 & 2423.83 & 28.53 & 2124.71 & 19.76 & 1784.61 & 22.75 & 0.67 & 0.15 & 83.99 \\
\hline Z39 & 0.16 & 1.12 & 7.62 & 2.33 & 0.34 & 2.04 & 2458.08 & 18.79 & 2187.38 & 20.67 & 1863.86 & 32.94 & 0.88 & 0.23 & 85.21 \\
\hline $\mathrm{Z} 23$ & 0.17 & 0.39 & 9.04 & 0.86 & 0.39 & 0.76 & 2497.96 & 6.68 & 2342.34 & 7.83 & 2115.89 & 13.79 & 0.88 & 0.16 & 90.33 \\
\hline $\mathrm{Z} 48$ & 0.17 & 0.89 & 8.71 & 1.87 & 0.37 & 1.64 & 2506.76 & 15.48 & 2307.99 & 17.00 & 2039.74 & 28.65 & 0.87 & 0.15 & 88.38 \\
\hline $\mathrm{Z3}$ & 0.17 & 0.36 & 9.16 & 1.07 & 0.39 & 1.01 & 2521.97 & 6.14 & 2354.19 & 9.82 & 2113.50 & 18.23 & 0.94 & 0.28 & 89.78 \\
\hline $\mathrm{Z} 30$ & 0.17 & 0.42 & 9.57 & 0.72 & 0.41 & 0.58 & 2522.02 & 7.19 & 2394.53 & 6.59 & 2193.95 & 10.85 & 0.76 & 0.36 & 91.62 \\
\hline Z2B & 0.17 & 0.50 & 9.74 & 0.84 & 0.41 & 0.68 & 2524.31 & 8.72 & 2410.78 & 7.77 & 2224.42 & 12.71 & 0.77 & 0.43 & 92.27 \\
\hline $\mathrm{Z} 22$ & 0.17 & 0.39 & 9.31 & 0.73 & 0.39 & 0.62 & 2532.17 & 6.77 & 2368.60 & 6.69 & 2130.94 & 11.17 & 0.80 & 0.35 & 89.97 \\
\hline $\mathrm{Z} 12$ & 0.17 & 0.76 & 10.38 & 1.28 & 0.44 & 1.03 & 2532.92 & 13.13 & 2469.69 & 11.86 & 2337.09 & 20.19 & 0.79 & 0.43 & 94.63 \\
\hline $\mathrm{Z} 44$ & 0.17 & 0.69 & 9.93 & 1.26 & 0.42 & 1.06 & 2533.00 & 11.96 & 2428.32 & 11.65 & 2250.62 & 20.06 & 0.82 & 0.18 & 92.68 \\
\hline Z4B & 0.17 & 0.78 & 10.18 & 1.56 & 0.43 & 1.36 & 2536.40 & 13.45 & 2451.50 & 14.47 & 2294.81 & 26.19 & 0.86 & 0.27 & 93.61 \\
\hline $\mathrm{Z} 17$ & 0.17 & 0.65 & 10.37 & 1.17 & 0.44 & 0.98 & 2537.14 & 11.16 & 2468.35 & 10.87 & 2329.33 & 19.15 & 0.82 & 0.36 & 94.37 \\
\hline Z29 & 0.17 & 0.77 & 10.08 & 1.02 & 0.42 & 0.67 & 2546.49 & 13.35 & 2442.20 & 9.44 & 2263.93 & 12.73 & 0.61 & 0.18 & 92.70 \\
\hline $\mathrm{Z} 37$ & 0.18 & 1.01 & 11.41 & 1.58 & 0.47 & 1.22 & 2558.54 & 17.33 & 2556.97 & 14.75 & 2495.37 & 25.20 & 0.76 & 0.29 & 97.59 \\
\hline $\mathrm{Z} 2 \mathrm{~N}$ & 0.18 & 0.33 & 10.40 & 1.22 & 0.43 & 1.18 & 2560.98 & 5.73 & 2470.86 & 11.33 & 2306.89 & 22.82 & 0.96 & 0.44 & 93.36 \\
\hline
\end{tabular}


Table 4.4 - Summary of LA-ICP-MS data of zircons from sample FL-105 (Riacho das Lajes Suite).

\section{Isotopic}

ratios

\begin{tabular}{|c|c|c|c|c|c|c|c|c|c|c|c|c|c|c|c|}
\hline \multirow[b]{2}{*}{$\begin{array}{l}\text { Grain } \\
\text { spot }\end{array}$} & \multicolumn{2}{|l|}{ ratios } & \multicolumn{8}{|c|}{ Ages } & \multirow[b]{2}{*}{${ }^{206} \mathrm{~Pb} /{ }^{238} \mathrm{U}$} & \multirow[b]{2}{*}{$\pm(1 \sigma)$} & \multirow[b]{2}{*}{ Rho } & \multirow[b]{2}{*}{$\mathrm{Th} / \mathrm{U}$} & \multirow[b]{2}{*}{$\begin{array}{l}\text { Conc. } \\
(\%)\end{array}$} \\
\hline & ${ }^{207} \mathrm{~Pb} /{ }^{206} \mathrm{~Pb}$ & $\pm(1 \sigma)$ & ${ }^{207} \mathrm{~Pb} /{ }^{235} \mathrm{U}$ & $\pm(1 \sigma)$ & ${ }^{206} \mathrm{~Pb} /{ }^{238} \mathrm{U}$ & $\begin{array}{l} \pm \\
(1 \sigma)\end{array}$ & ${ }^{207} \mathrm{~Pb} /{ }^{206} \mathrm{~Pb}$ & $\pm(1 \sigma)$ & ${ }^{207} \mathrm{~Pb} /{ }^{235} \mathrm{U}$ & $\pm(1 \sigma)$ & & & & & \\
\hline $\mathrm{Z1}$ & 0.13 & 0.65 & 5.87 & 1.13 & 0.33 & 0.93 & 2019.98 & 11.85 & 1956.81 & 9.83 & 1851.22 & 14.93 & 0.80 & 0.21 & 94.60 \\
\hline $\mathrm{Z} 2$ & 0.12 & 0.77 & 4.23 & 1.34 & 0.26 & 1.10 & 1906.44 & 14.16 & 1680.15 & 11.02 & 1467.06 & 14.45 & 0.81 & 0.22 & 87.32 \\
\hline $\mathrm{Z3}$ & 0.11 & 1.39 & 3.28 & 3.01 & 0.21 & 2.67 & 1799.81 & 25.94 & 1475.51 & 23.43 & 1228.33 & 29.91 & 0.89 & 0.23 & 83.25 \\
\hline $\mathrm{Z} 4$ & 0.13 & 0.79 & 6.58 & 1.29 & 0.37 & 1.03 & 2049.02 & 14.33 & 2056.16 & 11.40 & 2013.41 & 17.74 & 0.78 & 0.20 & 97.92 \\
\hline $\mathrm{Z5}$ & 0.12 & 0.36 & 5.24 & 1.18 & 0.31 & 1.12 & 1963.47 & 6.66 & 1859.60 & 10.06 & 1724.45 & 16.99 & 0.95 & 0.31 & 92.73 \\
\hline Z6 & 0.12 & 0.78 & 4.65 & 1.35 & 0.27 & 1.09 & 1950.71 & 14.39 & 1758.48 & 11.25 & 1561.26 & 15.18 & 0.80 & 0.28 & 88.78 \\
\hline $\mathrm{Z7}$ & 0.13 & 0.44 & 6.13 & 1.05 & 0.35 & 0.96 & 2031.00 & 7.93 & 1994.29 & 9.19 & 1911.34 & 15.85 & 0.90 & 0.24 & 95.84 \\
\hline $\mathrm{Z} 8$ & 0.13 & 0.68 & 5.34 & 1.15 & 0.31 & 0.92 & 1998.47 & 12.48 & 1875.42 & 9.80 & 1722.75 & 13.92 & 0.79 & 0.26 & 91.86 \\
\hline Z9 & 0.13 & 0.46 & 6.90 & 0.89 & 0.38 & 0.76 & 2059.23 & 8.44 & 2099.07 & 7.91 & 2088.51 & 13.58 & 0.83 & 0.30 & 99.50 \\
\hline $\mathrm{Z} 10$ & 0.11 & 0.67 & 3.09 & 1.60 & 0.20 & 1.45 & 1807.86 & 12.53 & 1430.81 & 12.28 & 1160.45 & 15.44 & 0.90 & 0.39 & 81.10 \\
\hline Z11 & 0.13 & 0.47 & 6.74 & 0.79 & 0.37 & 0.63 & 2054.71 & 8.61 & 2077.25 & 6.96 & 2049.42 & 11.04 & 0.76 & 0.43 & 98.66 \\
\hline $\mathrm{Z} 12$ & 0.12 & 0.60 & 4.67 & 1.20 & 0.28 & 1.04 & 1932.26 & 11.06 & 1761.77 & 10.05 & 1581.14 & 14.60 & 0.86 & 0.20 & 89.75 \\
\hline $\mathrm{Z} 13$ & 0.13 & 0.49 & 5.52 & 0.92 & 0.31 & 0.78 & 2007.40 & 8.99 & 1903.16 & 7.91 & 1764.49 & 12.01 & 0.82 & 0.29 & 92.71 \\
\hline Z14 & 0.12 & 0.60 & 5.08 & 0.91 & 0.30 & 0.69 & 1966.13 & 10.93 & 1833.19 & 7.74 & 1675.83 & 10.19 & 0.72 & 0.35 & 91.42 \\
\hline Z15 & 0.13 & 0.57 & 5.86 & 1.15 & 0.33 & 1.00 & 2004.80 & 10.47 & 1955.13 & 10.01 & 1861.92 & 16.21 & 0.86 & 0.32 & 95.23 \\
\hline Z16 & 0.13 & 0.42 & 6.21 & 1.29 & 0.35 & 1.22 & 2037.21 & 7.71 & 2006.12 & 11.26 & 1927.98 & 20.26 & 0.94 & 0.45 & 96.11 \\
\hline
\end{tabular}




\begin{tabular}{|c|c|c|c|c|c|c|c|c|c|c|c|c|c|c|c|}
\hline $\mathrm{Z} 17$ & 0.12 & 0.86 & 3.61 & 1.31 & 0.22 & 0.99 & 1871.08 & 16.02 & 1552.27 & 10.45 & 1295.05 & 11.63 & 0.74 & 0.29 & 83.43 \\
\hline Z18 & 0.13 & 0.43 & 6.20 & 0.84 & 0.35 & 0.72 & 2042.34 & 7.76 & 2005.11 & 7.32 & 1921.24 & 11.97 & 0.84 & 0.24 & 95.82 \\
\hline Z19 & 0.12 & 0.73 & 5.07 & 1.54 & 0.30 & 1.36 & 1962.88 & 13.39 & 1831.81 & 13.06 & 1676.13 & 20.01 & 0.88 & 0.33 & 91.50 \\
\hline Z21 & 0.13 & 0.44 & 5.82 & 1.28 & 0.33 & 1.20 & 2007.64 & 8.01 & 1949.84 & 11.09 & 1849.49 & 19.33 & 0.94 & 0.23 & 94.85 \\
\hline Z22 & 0.12 & 0.51 & 5.33 & 0.95 & 0.31 & 0.80 & 1977.04 & 9.27 & 1874.46 & 8.10 & 1739.34 & 12.21 & 0.83 & 0.33 & 92.79 \\
\hline Z23 & 0.13 & 0.55 & 6.06 & 0.97 & 0.34 & 0.80 & 2015.97 & 10.01 & 1985.23 & 8.44 & 1908.20 & 13.18 & 0.80 & 0.27 & 96.12 \\
\hline Z24 & 0.13 & 0.63 & 6.42 & 1.23 & 0.36 & 1.06 & 2026.29 & 11.44 & 2035.27 & 10.82 & 1994.67 & 18.18 & 0.85 & 0.36 & 98.00 \\
\hline $\mathrm{Z} 25$ & 0.12 & 0.53 & 4.53 & 1.62 & 0.27 & 1.53 & 1921.64 & 9.77 & 1735.95 & 13.45 & 1546.38 & 21.01 & 0.94 & 0.24 & 89.08 \\
\hline Z26 & 0.13 & 0.49 & 6.87 & 0.92 & 0.39 & 0.78 & 2032.35 & 8.89 & 2094.51 & 8.14 & 2106.53 & 13.97 & 0.83 & 0.34 & 100.57 \\
\hline $\mathrm{Z} 27$ & 0.13 & 0.57 & 6.80 & 0.88 & 0.38 & 0.66 & 2044.60 & 10.43 & 2085.20 & 7.75 & 2075.39 & 11.73 & 0.71 & 0.40 & 99.53 \\
\hline Z28 & 0.13 & 0.50 & 6.04 & 1.19 & 0.34 & 1.08 & 2013.95 & 9.13 & 1980.94 & 10.40 & 1901.95 & 17.86 & 0.90 & 0.23 & 96.01 \\
\hline Z29 & 0.13 & 0.41 & 5.71 & 0.94 & 0.32 & 0.85 & 2014.84 & 7.43 & 1932.18 & 8.14 & 1810.50 & 13.42 & 0.89 & 0.43 & 93.70 \\
\hline $\mathrm{Z} 30$ & 0.13 & 0.95 & 5.04 & 2.74 & 0.29 & 2.56 & 2013.24 & 17.40 & 1826.77 & 23.18 & 1626.23 & 36.86 & 0.94 & 0.42 & 89.02 \\
\hline
\end{tabular}

Table 4.5 - Summary of LA-ICP-MS data of zircons from sample LS-65 (Floresta Suite). 


\section{Isotopic}

ratios

\begin{tabular}{|c|c|c|c|c|c|c|c|c|c|c|c|c|c|c|c|}
\hline $\begin{array}{l}\text { Grain } \\
\text { spot }\end{array}$ & ${ }^{207} \mathrm{~Pb} /{ }^{206} \mathrm{~Pb}$ & $\pm(1 \sigma)$ & ${ }^{207} \mathrm{~Pb} /{ }^{235} \mathrm{U}$ & $\pm(1 \sigma)$ & ${ }^{206} \mathrm{~Pb} /{ }^{238} \mathrm{U}$ & $\begin{array}{l} \pm \\
(1 \sigma)\end{array}$ & ${ }^{207} \mathrm{~Pb} /{ }^{206} \mathrm{~Pb}$ & $\pm(1 \sigma)$ & ${ }^{207} \mathrm{~Pb} /{ }^{235} \mathrm{U}$ & $\pm(1 \sigma)$ & ${ }^{206} \mathrm{~Pb} /{ }^{238} \mathrm{U}$ & $\pm(1 \sigma)$ & Rho & $\mathrm{Th} / \mathrm{U}$ & $\begin{array}{l}\text { Conc. } \\
(\%)\end{array}$ \\
\hline Z01 & 0.13 & 0.45 & 6.76 & 0.77 & 0.38 & 0.63 & 2039.75 & 8.24 & 2080.37 & 6.84 & 2070.58 & 11.11 & 0.77 & 0.58 & 99.53 \\
\hline $\mathrm{Z} 02$ & 0.13 & 0.36 & 6.50 & 0.70 & 0.36 & 0.61 & 2042.20 & 6.55 & 2045.94 & 6.20 & 2000.06 & 10.42 & 0.82 & 0.73 & 97.76 \\
\hline 03 & 0.13 & 0.44 & 6.43 & 0.71 & 0.36 & 0.55 & 2035.44 & 8.07 & 2036.29 & 6.24 & 1987.78 & 9.48 & 0.72 & 0.80 & 97.62 \\
\hline $\mathrm{Z} 04$ & 0.13 & 0.52 & 6.58 & 0.82 & 0.37 & 0.63 & 2043.75 & 9.40 & 2056.50 & 7.20 & 2019.23 & 10.97 & 0.73 & 0.74 & 98.19 \\
\hline $\mathrm{Z} 05$ & 0.13 & 0.64 & 6.15 & 0.98 & 0.35 & 0.74 & 2037.65 & 11.73 & 1997.98 & 8.60 & 1912.12 & 12.32 & 0.72 & 0.49 & 95.70 \\
\hline$Z 06$ & 0.13 & 0.59 & 6.23 & 0.84 & 0.35 & 0.60 & 2035.56 & 10.74 & 2008.48 & 7.37 & 1934.05 & 10.04 & 0.66 & 0.56 & 96.29 \\
\hline $\mathrm{Z} 07 \mathrm{~N}$ & 0.13 & 0.46 & 5.53 & 0.72 & 0.32 & 0.55 & 2003.01 & 8.47 & 1904.85 & 6.19 & 1771.35 & 8.54 & 0.70 & 0.09 & 92.99 \\
\hline Z07B & 0.12 & 0.44 & 4.33 & 1.14 & 0.25 & 1.05 & 1953.94 & 8.06 & 1698.75 & 9.39 & 1461.92 & 13.74 & 0.92 & 0.12 & 86.06 \\
\hline Z08 & 0.13 & 0.61 & 6.11 & 0.94 & 0.34 & 0.71 & 2039.00 & 11.18 & 1992.07 & 8.18 & 1899.68 & 11.64 & 0.72 & 0.49 & 95.36 \\
\hline Z09 & 0.13 & 0.53 & 6.65 & 1.07 & 0.37 & 0.93 & 2043.85 & 9.70 & 2066.66 & 9.43 & 2039.20 & 16.19 & 0.85 & 0.65 & 98.67 \\
\hline Z10 & 0.13 & 0.34 & 6.33 & 0.62 & 0.35 & 0.52 & 2040.58 & 6.10 & 2021.94 & 5.44 & 1955.08 & 8.81 & 0.78 & 0.82 & 96.69 \\
\hline Z11 & 0.13 & 0.37 & 6.32 & 0.78 & 0.35 & 0.69 & 2035.38 & 6.75 & 2020.66 & 6.86 & 1957.59 & 11.63 & 0.86 & 0.58 & 96.88 \\
\hline Z12 & 0.13 & 0.38 & 5.68 & 0.81 & 0.32 & 0.71 & 2009.51 & 6.93 & 1929.02 & 6.96 & 1809.48 & 11.23 & 0.86 & 0.21 & 93.80 \\
\hline Z13 & 0.13 & 0.52 & 6.17 & 0.89 & 0.34 & 0.72 & 2043.24 & 9.49 & 1999.88 & 7.76 & 1910.49 & 11.87 & 0.78 & 0.68 & 95.53 \\
\hline $\mathrm{Z14N}$ & 0.13 & 0.39 & 6.44 & 0.75 & 0.36 & 0.64 & 2044.60 & 7.12 & 2037.63 & 6.59 & 1981.54 & 10.90 & 0.82 & 0.63 & 97.25 \\
\hline Z14B & 0.13 & 0.47 & 5.98 & 0.72 & 0.34 & 0.55 & 2024.69 & 8.50 & 1973.45 & 6.26 & 1877.95 & 8.94 & 0.70 & 0.42 & 95.16 \\
\hline $\mathrm{Z} 15 \mathrm{~N}$ & 0.13 & 0.54 & 6.17 & 0.85 & 0.35 & 0.66 & 2042.17 & 9.90 & 2000.90 & 7.47 & 1913.43 & 10.91 & 0.73 & 0.68 & 95.63 \\
\hline Z15B & 0.13 & 0.64 & 6.43 & 0.91 & 0.36 & 0.64 & 2048.64 & 11.64 & 2036.30 & 7.98 & 1975.06 & 10.94 & 0.66 & 0.74 & 96.99 \\
\hline Z16 & 0.13 & 0.61 & 6.55 & 1.03 & 0.37 & 0.82 & 2025.66 & 11.17 & 2052.55 & 9.05 & 2029.21 & 14.36 & 0.78 & 0.85 & 98.86 \\
\hline $\mathrm{Z} 17$ & 0.13 & 0.41 & 6.01 & 0.76 & 0.34 & 0.64 & 2014.36 & 7.40 & 1977.17 & 6.63 & 1894.46 & 10.57 & 0.81 & 0.20 & 95.82 \\
\hline Z18 & 0.13 & 0.31 & 6.00 & 0.62 & 0.34 & 0.53 & 2021.27 & 5.68 & 1976.41 & 5.38 & 1886.63 & 8.73 & 0.81 & 0.25 & 95.46 \\
\hline Z19 & 0.13 & 0.31 & 6.21 & 0.65 & 0.35 & 0.57 & 2030.22 & 5.56 & 2006.26 & 5.69 & 1934.85 & 9.60 & 0.85 & 0.74 & 96.44 \\
\hline$Z 20$ & 0.13 & 0.51 & 6.46 & 0.83 & 0.36 & 0.65 & 2026.95 & 9.36 & 2040.68 & 7.29 & 2004.59 & 11.21 & 0.74 & 0.69 & 98.23 \\
\hline
\end{tabular}




\begin{tabular}{|c|c|c|c|c|c|c|c|c|c|c|c|c|c|c|c|}
\hline Z21 & 0.13 & 0.46 & 6.55 & 0.93 & 0.37 & 0.81 & 2034.66 & 8.43 & 2052.59 & 8.19 & 2020.46 & 13.97 & 0.85 & 0.85 & 98.43 \\
\hline $\mathrm{Z} 22$ & 0.13 & 0.30 & 6.67 & 0.64 & 0.37 & 0.56 & 2038.61 & 5.54 & 2068.13 & 5.62 & 2047.29 & 9.80 & 0.84 & 0.74 & 98.99 \\
\hline $\mathrm{Z} 23$ & 0.13 & 0.52 & 6.49 & 0.93 & 0.37 & 0.78 & 2017.92 & 9.40 & 2044.98 & 8.21 & 2021.86 & 13.49 & 0.81 & 0.61 & 98.87 \\
\hline Z24 & 0.13 & 0.45 & 6.43 & 0.82 & 0.36 & 0.68 & 2024.19 & 8.18 & 2036.65 & 7.18 & 1999.40 & 11.74 & 0.81 & 0.65 & 98.17 \\
\hline $\mathrm{Z} 25$ & 0.13 & 0.66 & 6.00 & 1.09 & 0.34 & 0.88 & 2026.49 & 11.94 & 1975.45 & 9.51 & 1880.03 & 14.27 & 0.78 & 0.45 & 95.17 \\
\hline Z26 & 0.12 & 0.46 & 5.32 & 0.86 & 0.31 & 0.72 & 1971.43 & 8.42 & 1872.71 & 7.33 & 1741.01 & 11.04 & 0.82 & 0.73 & 92.97 \\
\hline $\mathrm{Z} 27$ & 0.13 & 0.63 & 6.24 & 0.96 & 0.35 & 0.72 & 2045.41 & 11.46 & 2009.74 & 8.36 & 1927.16 & 11.96 & 0.72 & 0.64 & 95.89 \\
\hline
\end{tabular}

Table 4.6 - Summary of LA-ICP-MS data of zircons from sample LS-60 (Floresta Suite). 


\begin{tabular}{|c|c|c|c|c|c|c|c|c|c|}
\hline Sample & Unit & $\begin{array}{l}\mathrm{Sm} \\
(\mathrm{ppm})\end{array}$ & $\mathrm{Nd}(\mathrm{ppm})$ & ${ }^{147} \mathrm{Sm} /{ }^{144} \mathrm{Nd}$ & ${ }^{143} \mathrm{Nd} /{ }^{144} \mathrm{Nd}( \pm 2 \mathrm{SE})$ & $\varepsilon \mathrm{Nd}(0)$ & $\varepsilon N d(t)$ & $\mathrm{U}-\mathrm{Pb}$ age $(\mathrm{Ga})$ & $\mathrm{T}_{\mathrm{DM}}(\mathrm{Ga})$ \\
\hline FL105 & R.L.S. & 2.28 & 17.07 & 0.081 & $0.510515( \pm 17)$ & -41.41 & $-2,001$ & 2.648 & 2.90 \\
\hline FL53 & R.L.S. & 4.50 & 33.53 & 0.081 & $0.510637( \pm 20)$ & -39.04 & 0,361 & 2.648 & 2.76 \\
\hline FL58 & R.L.S. & 2.92 & 23.14 & 0.076 & $0.510522( \pm 14)$ & -41.28 & $-0,251$ & 2.648 & 2.79 \\
\hline FL46a & R.L.S. & 2.37 & 19.88 & 0.072 & $0.510477( \pm 19)$ & -42.15 & 0,238 & 2.648 & 2.76 \\
\hline FL56 & R.L.S. & 1.87 & 16.01 & 0.071 & $0.510430( \pm 12)$ & -43.08 & $-0,205$ & 2.648 & 2.78 \\
\hline FL57 & R.L.S. & 2.35 & 17.26 & 0.082 & $0.510587( \pm 09)$ & -40.01 & $-1,101$ & 2.648 & 2.85 \\
\hline FL54B & R.L.S. & 2.01 & 12.15 & 0.100 & $0.510864( \pm 05)$ & -34.62 & $-1,802$ & 2.648 & 2.93 \\
\hline FL 70 & F.S. & 1.56 & 12.06 & 0.078 & $0.511049( \pm 18)$ & -31.00 & +0.94 & 2.098 & 2.23 \\
\hline FL67 & F.S. & 7.85 & 35.43 & 0.134 & $0.511818( \pm 18)$ & -15.99 & +0.91 & 2.098 & 2.33 \\
\hline Fl 106a & F.S. & 4.09 & 18.53 & 0.134 & $0.511547( \pm 17)$ & -21.28 & -4.33 & 2.098 & 2.86 \\
\hline FL 95b & F..S. & 1.93 & 9.162 & 0.127 & $0.511897( \pm 03)$ & -14.45 & +4.24 & 2.098 & 2.01 \\
\hline FL 65 & F.S. & 3.74 & 18.15 & 0.097 & $0.511590( \pm 08)$ & -20.44 & -0.99 & 2.098 & 2.48 \\
\hline FL 73 & F.S. & 4.88 & 25.17 & 0.117 & $0.511588( \pm 15)$ & -20.48 & +0.92 & 2.098 & 2.29 \\
\hline FL 104a & F.S. & 1.33 & 10.27 & 0.078 & $0.516031( \pm 25)$ & -39.15 & -7.36 & 2.098 & 2.72 \\
\hline Fl 66 & F.S. & 11.83 & 69.88 & 0.102 & $0.510722( \pm 19)$ & -37.38 & -12.03 & 2.098 & 3.19 \\
\hline
\end{tabular}




$\begin{array}{llllllllll}\text { Fl } 59 & \text { F.S. } & 2.69 & 18.86 & 0.086 & 0.510594( \pm 16) & -39.87 & -10.17 & 2.098 & 2.93 \\ \text { Fl } 40 & \text { F.S. } & 2.84 & 17.04 & 0.100 & 0.511191( \pm 08) & -28.23 & -2.42 & 2.098 & 2.49 \\ \text { Fl } 102 & \text { F.S. } & 10.04 & 80.02 & 0.075 & 0.510671( \pm 19) & -38.37 & -5.85 & 2.098 & 2.36 \\ \text { Fl 32a } & \text { F.S. } & 10.05 & 76.46 & 0.079 & 0.510751( \pm 04) & -36.81 & -5.25 & 2.098 & 2.60 \\ \text { Fl } 88 & \text { F.S. } & 0.54 & 3.018 & 0.109 & 0.511660( \pm 10) & -19.08 & +4.47 & 2.098 & 2.01 \\ \text { Fl } 69 & \text { F.S. } & 3.48 & 17.72 & 0.118 & 0.511553( \pm 13) & -21.17 & -0.17 & 2.098 & 2.38 \\ \text { Fl } 60 & \text { F.S. } & 4.76 & 26.70 & 0.107 & 0.511388( \pm 05) & -24.38 & -0.45 & 2.098 & 2.37 \\ \text { Fl } 68 & \text { F.S. } & 2.72 & 19.42 & 0.084 & 0.511112( \pm 18) & -29.77 & +0.45 & 2.098 & 2.27 \\ \text { Fl } 62 & \text { F.S. } & 8.96 & 47.45 & 0.114 & 0.511552( \pm 14) & -21.18 & +1.05 & 2.098 & 2.27\end{array}$

Table 4.7 - Summary of Nd isotope data for the metaplutonic rocks of Riacho das Lajes (R.L.S.) and Floresta Suites (F.S.). 


\subsection{References}

Almeida, F.F.M., Hasui, Y., Brito Neves, B.B., Fuck, R.A., 1981. Brazilian structural provinces: an introduction. Earth Science Reviews 18, 1-29.

Archanjo, C.J., Hollanda, M.H.B.M., Rodrigues, S.W., Brito Neves, B.B., 2008. Fabrics of pre- and syntectonic granite plutons and chronology of shear zones in the Eastern Borborema Province, NE Brazil. Journal of Structural Geology 30, 310-336.

Archanjo, C.J., Viegas, L.G., Freimann, Hollanda, M.H.B.M. 2013. O Lineamento Patos: Estrutura e evolução. In: $25^{\circ}$ Simpósio de Geologia do Nordeste, Proceedings, pp. 481482.

Arndt, N.T., 2013. Formation and evolution of the Continental Crust. Geochemical Perspectives (European Association of Geochemistry) 2, 405-533.

Ávila, C.A., Teixeira, W., Cordani, U.G., Moura, C.A.V., Pereira, R.M., 2010. Rhyacian (2.23-2.20 Ga) juvenile accretion in the southern São Francisco craton, Brazil: geochemical and isotopic evidence from the Serrinha magmatic suite, Mineiro Belt. Journal of South American Earth Sciences 29, 464-482.

Baratoux, L., Metelka, V., Naca, S., Jessel, M.W., Gregoire, M., Ganne, J., 2011. Juvenile Paleoproterozoic crust evolution during the Eburnean orogeny $(2.20-2.0 \mathrm{Ga})$, western Burkina Faso. Precambrian Research 191-18-45.

Barbosa, J.S.F., Sabaté, P. 2004. Archaean and Paleoproterozoic crust of the São Francisco Craton, Bahia, Brazil: Geodynamic features. Precambrian Research 133, 127.

Barker, F., Arth, J.G., 1976. Generation of trondhjemite-tonalite liquids and Archean bimodal trondhjemite-basalt suites. Geology 4, 596-600.

Bleeker, W., 2003. The late Archean record: a puzzle in ca. 35 pieces. Lithos, 71, 99134.

Blocks, S., Ganne, J., Baratoux, L., Zeh, A., Parra-Avila, L.A., Jessel, M., Ailleres, L., Siebenaller, L., 2015. Petrological and geochronological constraints on lower crust exhumation during Paleoproterozoic (Eburnean) orogeny, NW Ghana, West African Craton. Journal of Metamorphic Petrology 33, 436-494. 
Bradley, D.C., 2011. Secular trends in the geologic record and the supercontinent cycle: Earth and Planetary Science Letters 108, 16-33.

Brito Neves, B.B., 1975. Regionalização Geotectônica Do Précambriano Nordestino (Phd thesis). Universidade de São Paulo, São Paulo, p. 198.

Brito Neves, B.B., 2011. The Paleoproterozoic in the South American continent: diversity in the geologic time. Journal of South American Earth Sciences 32, 270-286.

Brito Neves, B.B., Santos, E.J., Schmus, W.R.Q., 2000. Tectonic history of the Borborema Province. In: Umberto Cordani; Edson José Milani; Antonio Thomaz Filho; Diogenes de Almeida Campos (Org.). Tectonic Evolution of South America. Rio de Janeiro: 31st International Geological Congress, pp. 151-182. Special Publication.

Brito Neves, B.B., Van Schmus, W.R., Santos, E.J., Campos Neto, M.C., Kozuch, M., 2005. O Evento Cariris Velhos na Província Borborema: integração de dados, implicações e perspectivas. Revista Brasileira de Geociências 25, 279-296.

Brito Neves, B.B., Sproesser, W.M., Petronilho, L.A., Souza, S.L., 2013. Contribuição a geologia e geocronologia do Terreno Rio Capibaribe (TRC, Província Borborema). Geologia USP - Série Científica 13, 97-122.

Brito Neves, B.B., Fuck, R.A., Pimentel, M.M. 2014. The Brasiliano collage in South America: a review. Brazilian Journal of Geology 44, 493-518.

Brown, M., 2009. Metamorphic patterns in orogenic systens and the geological record. in: P.A. Cawood, A. Cawood, A. Kröner (Eds.), Accretionary Orogens in Space and Time, Geological Society, London, Special Publications, vol. 318 (2009), pp. 37-74.

Bühn, B.M., Pimentel, M.M., Matteini, M., Dantas, E.L., 2009. High spatial resolution analysis of $\mathrm{Pb}$ and $\mathrm{U}$ isotopes for geochronology by laser ablation multicollector inductively coupled plasma mass spectrometry (LA-MC-ICP-MS). Anais da Academia Brasileira de Ciências 81, 1-16.

Castillo, P.R., 2006. An overview of adakite petrogenesis. Chinese Science Bulletin 51, 257-268. 
Caxito, F.A., Uhlein, A., Dantas, E.L. 2014a. The Afeição augen-gneiss suíte and the recorf of the Cariris Velhos Orogeny (1000-960 Ma) within the Riacho do Pontal fold belt, NE Brazil. Journal of South American Earth Sciences 51, 12-27.

Caxito, F.A., Uhlein, A. Ross, S., Uhlein, G.J. 2014b. Neoproterozoic oceanic crust remmants in northeast Brazil. Geology 42, 387-390.

Cavosie, A.J., Valley, J.W., Wilde, S.A. 2006. Correlated micro-analysis of zircon: trace element,d180, and $\mathrm{U}-\mathrm{Th}-\mathrm{Pb}$ isotopic constraints on the igneous origin of complex>3900 Ma detrital grains. Geochim Cosmochim Acta 70, 5601-5616.

Cawood, P.A., Hawkesworth, C.J., Dhuime, B., 2013. The continental record and the generation of continental crust. Geological Society of America Bulletin 125, 14-32.

Condie, K.C., 1998. Episodic continental growth and supercontinents: a mantle avalanche connection? Earth and Planetary Science Letters 163, 97-108.

Condie, K.C., 2000. Episodic continental growth models: afterthoughts and extensions. Tectonophysics 322, 153-162.

Condie, K.C., 2005. TTGs and adakites: are they both slab melts? Lithos 80, 33-44.

Condie, K.C., Kröner., 2013. The building blocks of continental crust: Evidence for a major change in tectonic setting of continental growth at the end of the Archean. Gondwana Research 23, 394-412.

Cordani, E.G., Pimentel, M.M., Aráujo, C.E.G., Fuck, R.A., 2013. The significance of the Transbrasiliano-Kandi tectonic corridor for the amalgamation of West Gondwana. Brazilian Journal of Geology 43, 583-597.

Costa, F.G., Palheta, E.S.M., Rodrigues, J.B., Gomes, I.P.G., Vasconcelos, A.M. 2015. Geochemistry and $\mathrm{U}-\mathrm{Pb}$ zircon ages of plutonic rocks from the Algodões granitegreenstone terrane, Troia Massif, northern Borborema Province, Brazil: Implications for Paleoproterozoic subdiction-accretion processes. Journal of South American Earth Sciences 59, 45-68. 
Dantas, E.L., Souza, Z.S., Wernick, E., Hackspacher, P.C., Martin, H., Xiadong, D., Li, J.W., 2013. Crustal growth in the 3.4-2.7 Ga São José do Campestre Massif, Borborema Province, NE Brazil. Precambrian Research 227, 12-156.

Davies, J.H., von Blanckerburg, F., 1995. Slab breakoff: a model of lithospheric detatchment and its test in the magmatism and deformation of collisional orogens. Earth and Planetary Science Letters 129, 85-102.

Delgado, I.M., Souza, J.D., Silva, L.C., Silveira Filho, N.C., Santos, R.A., Pedreira, A.J., Guimarães, J.T., Angelin, L.A.A., Vasconcelos, A.M., Gomes, I.P., Lacerda Filho, J.V., Valente, C.R., Perrota, M.M., Heineck, C.A. 2003. Geotectônica do Escudo Atlântico: In: Bizzi, L.A., Schobbenhaus, C., Vidotti, R.M., Gonçalves, J.H. (eds). Geologia, Tectônica e Recursos Minerais do Brasil. CPRM, 227-234.

DePaolo, D.J., 1981. A neodymium and strontium isotopic study of the Mesozoic calcalkaline granitic batholiths of the Sierra Nevada and Peninsular Ranges, California. Journal of Geophysical Researcg. 86, 10470-10488.

de Wit, M.J., Roering, C.H., Armonstrong, R.J., Ronde, R.A., Green C.E.J., Tredoux, R.E.W., Pederdy, M., Hart, R.A., 1992. Formation of an Archean continent. Nature 347, 553-563.

de Wit, M. J. and Tinker, J. 2004. Crustal structures across the central Kaapvaal Craton from deep-seismic reflection data. South African Journal of Geology 107, 185-206.

Defant, M.J., Drummond, M.S. 1990. Derivation of some modern arc magmas by melting of young subducted lithosphere. Nature 347, 662- 665.

Drummond, M.S., Defant, M.J., 1990. A model for trondhjemite-tonalite-dacite genesis and crustal growth via slab melting: Archean to modern comparisons. Journal of Geophysical Research 95, 21503-21521.

Evans, D.A.D., Mitchell, R.N., 2011. Assembly and breakup of the core of Paleoproterozoic-Mesoproterozoic supercontinent Nuna. Geology 39, 443-446.

Farina, F., Albert, C., Lana, C., 2015. The Neoarchean transition between medium- and high-K granitoids: Clues from the Southern Sao Francisco Craton (Brazil). Precambrian Research 266, 375-394. 
Fetter, A.H., Van Schmus, W.R., dos Santos, T.J.S., Arthaud, M., Nogueira Neto, J., Arthaud, M. 2000. U-Pb and Sm-Nd geochronological constraints on the crustal evolution and basement architecture of Ceara State, NW Borborema Province, NE Brazil: implications for the existence of the Paleoproterozoic supercontinent Atlantica. Revista Brasileira de Geociencias 30, 102-106.

Fetter, A.H., Santos, T.J.S., Van Schmus, W.R., Hackhpacher, P.C., Brito Neves, B.B., Arthaud, M.H., Nogueira Neto, J.A., Wernick, E. 2003. Evidence for Neoproterozoic continental arc magmatism in the Santa Quiteria Batholith of Ceará State, NW Borborema Province, NE Brazil: implications for the assembly ofWest Gondwana. Gondwana Research 6, 265-273.

Feybesse, J.L., Billa, M., Guerrot, C., Duguey, R., Lescuyr, J.L., Milesi, J.P., Bouchot, V., 2006. The The Paleoproterozoic Ghanian Province: geodynamic model and ore controls, including regional stress modelling. Precambrian Research 149, 149-196.

Foley, S.F., Barth, M.G., Jenner, G.A., 2000. Rutile/melt partition coefficient for trace elements and an assesment of the influence of rutile on the trace element characteristics of subduction zone magmas. Geochemistry at Cosmochimica Acta 64, 933-938.

Frost, B.R., Barnes, C.G., Collins, W.J., Arculus, R.J., Ellis, D.J., Frost, C.D., 2001. A geochemical classification of granitic rocks. Journal of Petrology 42, 2033-2048.

Ganade de Araújo, C.E., Weinberg, R.F., Cordani, U.G., 2014a. Extruding the Borborema Province (NE-Brazil): a two-stage Neoproterozoic collision process. Terra Nova 26, 157-168.

Ganade de Araujo, C.E., Cordani, G.U., Weinberg, R., Basei, M.A.S., Armostrong, R., Sato, K. 2014b. Tracing Neoproterozoic subduction in the Borborema Province (NEBrazil): clues from $\mathrm{U}-\mathrm{Pb}$ geochronology and $\mathrm{Sr}-\mathrm{Nd}-\mathrm{Hf}-\mathrm{O}$ isotopes on granitoids and migmatites. Lithos 202-203, 167-189.

Ganade de Araujo, C.E, Rubatto, D., Hermann, J., Cordani, G.U., Caby, R., Basei, M.A.S. 2014c. Ediacaran 2,500 km-long synchronous deep continental subduction in the West Gondwana Orogen. Nature Communications 1, 1-8. 
Gióia, S.M.C.L., Pimentel, M.M., 2000. The Sm-Nd isotopic method in the geocrhronology laboratory of the University of Brasilia. Anais da academia brasileira de ciências 72, 219-245.

Griffin W.L., Belousova, E.A., Shee, S.R., Pearson, N.J., O’Reilly, S.Y., 2004. Archean crustal evolution in the northern Yilgran Craton: $\mathrm{U}-\mathrm{Pb}$ and Hf-isotope evidence from detrital zircons. Precambrian Research 2004, 231-282.

Halla, J., can Hunen, J.,, Heilmo E., Hottla, P., 2009. Geochemical and numerical constraints on Neoarchean plate tectonics. Precambrian Research 175, 155-162.

Hawkesworth, C.J., Dhuime, B., Pietranik, A.B., Cawood, P.A., Kemp., A.I.S., Storey, C.D., 2010. The generation and evolution of the continental crust. Journal of the Geological Society 167, 229-248.

Hein, K.A.A., 2010. Succession of structural events in the Goren greenstone belt (Burkina Faso): Implications for West African tectonics. Journal of African Earth Sciences 58, 83-94.

Heilimo, E., Halla, J., Hölttä, P., 2010. Discrimination and origin of the sanukitoid series: geochemical constraints from the Neoarchean western Karelian Province (Finland). Lithos 115, 27-39.

Hollister, L.S., Andronicos, C.L., 2006. Formation of new continental crust in Western British Columbia during transpression and transtension. Earth and Planetary Science Letters 249, 29-38.

Jackson, S.E., Pearson, N.J., Griffin, W.L., Belousova, E.A., 2004. The application of laser ablation-inductively coupled plasma-mass spectrometry to in situ U-Pb zircon geochronology. Chemical Geology 211, 47-69.

Johnson, T., Brown, M., Kaus, B.J.P., van Tongeren, J.A., 2013. Delamination and recycling of Archaean crust caused by gravitational instabilities. Nature Geoscience 7, $47-52$.

Kelley, A.K., Plank, T., Newman, S., Stolper, E.M., Grove, T.L., Parman, S., Hairu, E.H., 2010. Mantle melting as a function of water content beneath the Mariana Arc. Journal of Petrology 51, 1711-1738. 
Klemme, S., Gunther, D., Hametner, K., Prowatke, S., Zack, T., 2006. The partitioning of trace elements between ilmenite, ulvospinel, armalcolite and silicate melts with implications for the early differentiation of the moon. Chemical Geology 234, 251-263.

Krammers, J.D., McCourt, S., van Reenen, D., 2006. The Limpopo Belt. In: Kröner, A. (Ed.), The Geology of South Africa. Geological Society of South Africa, Johannesburg, South Africa, pp. 209-236.

Kozuch, M., 2003. Isotopic and trace element geochemistry of Early Neoproterozoic gneissic and metavolcanic rocks in the Cariris Velhos Orogen of the Borborema Province, Brazil, and their bearing tectonic setting (PhD thesis). Kansas University, Lawrence, p. 199.

Laurent, O., Paquette, J.L., Martin, H., Doucelance, R., Moyen, J.F., 2013. LA-ICP-MS dating of zircons from Meso- and Neoarchean granitoids of the Pietsburg block (South Africa): Crustal evolution at the northern margin of the Kaapval craton. Precambrian Research 230, 209-226.

Laurent, O., Martin, F., Moyen, J.F., Doucelance, R., 2014. The diversity and evolution of late-Archean granitoids: Evidence for the onset of "modern-style" plate tectonics between 2.0 and 2.5 Ga. Lithos 205, 208-235.

Lima, M.I.C., Gava, A., Fernandes, P.E.C.A., Pires, J.L., Siga Jr, O., 1985. Projeto titanado de Floresta. Minérios de Pernambuco/Radam Brasil, 314 pp.

Lima, V.A.G., Berrocal, J., Soares, J.E.P., Fuck, R.A. 2015. Deep seismic reflection experiment in Northeast Brazil: new constraints for Borborema Province evolution. Journal of South American Earth Sciences 58, 335-349.

Maniar, P.D., Piccoli, P.M., 1989. Tectonic discrimination of granitoids. The Geological Society of America Bulletim 101, 635-643.

Martin, H., 1986. Effect of steeper Archean geothermal gradient on geochemistry of subduction-zone magmas. Geology 14, 753-756.

Martin, H., Smithies, R.H., Rapp, R., Moyen, J.F., Champion, D. 2005. An overview of adakite, TTG and sanukitoid: relationships and some implications for crustal evolution. Lithos 79, 1-24. 
Martin, H., Moyen, J.F., Rapp, R., 2010. Sanukitoids and the ArchaeanProterozoicboundary. Transactions of the Royal Society of Edinburgh-Earth Sciences $100,15-33$.

Martins, G., Oliveira, E.P., Lafon, J., 2009. The Algodões amphibolite tonalite gneisse sequence, Borborema Province, NE Brazil: Geochemical and geochronological evidenc for Paleoproterozoic accretion of oceanic plateau/back-arc basalts and adakitic plutons. Gondwana Research 15, 71-85.

Matteinni, M., Junges, S.L., Dantas, E.L., Pimentel, M.M., Buhn, B.M., 2009. In situ zircon $\mathrm{U}-\mathrm{Pb}$ and $\mathrm{Lu}-\mathrm{Hf}$ isotope systematic on magmatic rocks: insights on the crustal evolution of the Neoproterozoic Goiás Magmatic Arc, Brasília belt, Central Brazil. Gondwana Reearch. 16, 200-212.

McDonough, W.F., Sun, S.S., 1995. The composition of the Earth. Chemical Geology $120,223-253$.

Menzies, M.A., Rogers, Tindle, A., Hawkesworth, C., 1987. Metasomatic and enrichment processes in lithospheric peridotites, an effect of asthenosphere-litosphere interaction. In: Menzies, M.A., Hawkesworth, C.J. (Eds.), Mantle Metasomatism. Academic press, London, pp. 313-361.

Moyen, J.F., Martin, H., Jayananda, M., Auvray, B., 2003. Late Archaean granites: a typology based on the Dharwar Craton (India). Precambrian Research 127 (1-3), 103123.

Moyen, J.F., Stevens, G., 2006. Experimental constraints on TTG petrogenesis: implications for Archean geodynamics. In Benn, K., Mareschal, J.-C., Condie, K.C. (Eds.), Archean Geodynamics and Environments. AGU, pp. 149-178.

Moyen, J.F., Martin, H., 2012. Forty years of TTG research. Lithos 148, 312-336.

Neves, S.P., Lages, G.A., Brasilino, R.G., Miranda, A.W.A., 2015. Paleoproterozoic accretionary and collisional processes and the build-up of the Borborema Province (NE Brazil): Geochronological and geochemical evidence from the Central Domain. Journal of South American Earth Sciences 58, 165-187. 
Nielsen, R., 2007. Geochemical Earth Reference Model (GERM) partition coefficient (Kd) data base. Avaliable on the website: http://www.geo.oregonstate.edu/people/faculty/nielsenr.htm.

Niu, Y., O`Hara, M.J., 2009. MORB mantle hosts the missing Eu (Sr, Nb, Ta and Ti( in the continental crust: New perspectives on crustal growth, crust mantle differentiation and chemical structure of oceanic upper mantle. Lithos 112, 1-17.

O’Connor, T.J., 1965. A classification for quartz-rich igneous rocks based on feldspar ratios. US Geological Survey Professional Paper 52B, 79-84.

Oliveira, R.G., 2008. Arcabouço Geofísico, Isostasia e causas do magmatismo cenozóico da Província Borborema e de sua Margem Continental (NE do Brasil) (PhD thesis). Universidade Federal do Rio Grande do Norte, Natal, p. 411.

Oliveira, E.P., Souza, Z.S., McNaughton, N., Lafon, J.M., Costa, F.G., Figueiredo, A.M., 2011. The Rio Capin volcanic-plutonic-sedimentary belt, São Francisco Craton, Brazi: geological, geochronological and isotopic evidence for oceanic arc accretion during Paleoproterozoic continental collision. Gondwana Research 19, 735-750.

Pearce, J.A., 1982. Trace elements characteristics of lavas from destructive plate boundaries. In: Thorpe, R.S. (Ed.), Andesites. John Wiley and Sons, London, pp. 525548.

Pearce, J.A., Harris, N.B.W., Tindle, A.G., 1984. Trace element discrimination diagrams for the tectonic interpretation of granitic rocks. Journal of Petrology 25, 956983.

Rapp, R.P., Watson, E.B., 1995. Dehydration melting of metabasalt at 8-32 kbar: implications for continental growth and crust- mantle recycling. Journal of Petrology 36, 891-931.

Rapp, R.P., Shimizu, N., Norman, M.D. 2003. Growth of early continental crust by partial melting of eclogite. Nature 425, 605-609.

Reddy, S.M., Evans, D.A.D., 2009, Palaeoproterozoic supercontinents and global evolution: Correlations from core to atmosphere, in Reddy, S.M., et al., eds., 
Palaeoproterozoic supercontinents and global evolution: Geological Society of London Special Publication 323, p. 1-26.

Rodrigues, S.W.O., Brito Neves, B.B., 2008. Padrões isotópicos Sm-Nd no limite entre os Terrenos Alto Pajeú e Alto Moxotó (PB). Revista Brasileira de Geociências 38, 211 227.

Rogers, J.J.W., Santosh, M., 2002. Configuration of Columbia, a Mesoproterozoic supercontinent. Gondwana Research 5, 5-22.

Rollinson, H., 1993. Using geochemical data: evaluation, presentation, interpretation. Longman Scientific \& Thecnical, New York, Essex, p. 344.

Romano, R., Lana, C., Alkmim, F.F., Stevens, G.S., Armstrong, R., 2013. Stabilization of the southern portion of the Sao Francisco Craton, SE Brazil, through a long lived period of potassic magmatism. Precambrian Res. 224, 143-159.

Rudnick, R.L., 1995. Making continental crust. Nature 378, 571-578.

Santos, E.J., 1995. O complexo granítico Lagoa das Pedras: acresção e colisão na região de Floresta (Pernambuco), Província Borborema ( $\mathrm{PhD}$ thesis). Instituto de Geociências da Universidade de São Paulo, São Paulo, p. 228.

Santos, E.J., 1996. Ensaio preliminar sobre terrenos e tectônica acrecion_aria na Província Borborema. In: SBG, Congresso Brasileiro de Geologia, 39o, Salvador, Proceedings, pp. 47-50.

Santos, E.J., Medeiros, V.C., 1999. Constraints from granitic plutonism on proterozoic crustal growth of the Transverse Zone, Borborema Province, NE-Brazil. Revista Brasileira de Geociências 29, 73-84.

Santos, E.J., Nutman, A.P., Brito Neves, B.B., 2004. Idades SHRIMP U-Pb do Complexo Sertânia: implicações sobre a evolução tectônica da Zona Transversal, Província Borborema. Geol. USP - Série Científica 4, 1-12.

Santos, E.J., Van Schmus,W.R., Kozuch, M., Brito Neves, B.B., 2010. The Cariris Velhos tectonic event in northeast Brazil. J. South Am. Earth Sci. 29, 61-76. 
Santos, E.J., Souza Neto, J.A., Carmona, L.C.M., Armostrong, R., Santos, L.C.M.L., Mendes, L.U.S., 2013. The metacarbonate rocks of Itatuba (Paraíba): a record of sedimentary recycling in a Paleoproterozoic collision zone of the Borborema Province, NE Brazil. Precambrian Research 224, 454-471.

Santos, L.C.M.L., Santos, E.J., Dantas, E.L., Lima, H.M., 2012. Análise estrutural e metamórfica da região de Sucuru (Paraíba): Implicações sobre a evolução do Terreno Alto Moxotó, Província Borborema. Geologia USP - Série Científica 12, 5-20.

Santos, L.C.M.L., Dantas, E.L., Santos, E.J., Santos, R.V., Lima, H.M., 2015a. Early to late Paleoproterozoic magmatism in NE Brazil: the Alto Moxoto Terrane and its tectonic implications for the pre-West Gondwana assembly. Journal of South American Earth Sciences.58, 188-209.

Santos, L.C.M.L., Fuck, R.A., Santos, E.J., Dantas, E.L., 2015b. Análise tectônica de terrenos: metodologia, aplicação em cinturões orogênicos e exemplo das províncias Tocantins e Borborema, Brasil. Geonomos 22, 51-63.

Santos, R.V., Santos, E.J., Souza Neto, J.A., Carmona, L.C.M., Sial, A.N., Mancine, L.H., Santos, L.C.M.L., Nascimento, G.H., Mendes, L.U.D.S., Anastacio, E.M.F., 2012b. Isotope geochemistry of Paleoproterozoic metacarbonates from Itatuba, Borborema. Province, Northeastern Brazil: evidence of marble melting within a collisional suture. Gondwana Research 21, 1-13.

Semprich, J., Moreno, J.A., Oliveira, E.P., 2015. Phase equilibria and trace element modeling of Archean sanukitoid melts. Precambrian Research 269, 122-138.

Shaw, D.M., 1970. Trace element fractionation during anatexis. Geochimica and Cosmochimica Acta 34, 237-243.

Shirey, S.B., Hanson, G.N., 1984. Mantle-derived Archaean monzodiorites and trachyandesites. Nature 310, 222-224.

Silva, L.C., Costa, F.G., Armstrong, R., McNaughton, N.J., 2014. U-Pb (SHRIMP) zircon dating and $\mathrm{Nd}$ isotopes at basement inliers from Northern Borborema Province, Ceará State, NE Brazil: evidences for the Archean and Paleoproterozoic crustal evolution. In: 9th South American Symposium on Isotope Geology, São Paulo, Brazil, p. 175. 
Smithies, R.H., Champion, D.C. 2000. The Archean high-Mg diorite suite: links to Tonalite-Trondhjemite-Granodiorite magmatism and implications for Early Archean crustal growth. Journal of Petrology 41, 1653-1671.

Stern, R.A., Hanson, G.N., 1991. Archaean High-Mg granodiorites: a derivative of light rare earth enriched monzodiorites of mantle origin. Journal of Petrology 32, 201-238.

Streckeisen, A.L., 1976. To each plutonic rocks its proper name. Earth Science Reviews $12,1-33$.

Sylvester, P.J., 1994. Archaean granite plutons. In: K.C. Condie (Ed.), Archaean crustal evolution, developments in Precambrian Geology. V. 11, Elsevier, Amsterdam, pp. 261314.

Tatrumi, Y., Eggins, S. 1995. Subduction Zone Magmatism. Blackwell Science, Oxford, UK.

Teixeira, W., Sabaté, P., Barbosa, J.S.F., Noce, C.M., Carneiro, M.A. 2000. Archean and Paleoproterozoic Tectonic evolution of the São Francisco Craton, Brazil. In: Cordani, U.G., Milani, E.J., Thomas Filho, A., Campos, D.A. (Eds.), Tectonic Evolution of the South America. In: Int. Geol. Congr. 31, Rio de Janeiro, pp. 101-137.

Trompette, R., 1994. Geology of Western Gondwana, Pan African-Brasiliano Aggregation of South America and Africa. A.A. Balkema, Rotterdam, p. 350.

van Keken, P.E., Kiefer, B., Peacock, S.N. 2002. High-resolution models of subduction zones: Implications for mineral dehydratation reactions and the transport of water into the deep mantle. Geochemistry, Geophysics and Geosystems 3, 1-10.

Van Schmus, W.R., Brito Neves, B.B., Hackspacher, P.C., Babinski, M., 1995. U/Pb and $\mathrm{Sm} / \mathrm{Nd}$ geochronologic studies of the eastern Borborema Province, Northeast Brazil: initial conclusions. Journal of South American Earth Sciences 8, 267-288.

Van Scmmus, W.R., Oliveira, E.P., Silva Filho, A.F., Toteu, F., Penaye, J., Guimarães, I.P., 2008. Proterozoic links between the Borborema Province, NE Brazil, and the Central African Fold Belt. Geological Society of London Special Publication 294, 6669. 
Van Schmus, W.R., Kozuch, M., Brito Neves, B.B., 2011. Precambrian history of the Zona Transversal of the Borborema Province. Joutnal of South American Earth Sciences 31, 227-252.

Wan, Y.S., Xie, S.W., Yang, C.H., Kröner, A., Ma, M.Z., Dong, C.Y., Di, L.L., Xie, H.Q., Liu, D.Y. 2014. Early Neoarchean ( 2.7 Ga) tectono-thermal events in the North China Craton: a synthesis. Precambrian Research, 247, 45-63.

Wang, A., Liu, Y., 2012. Neoarchean (2.5-2.8 Ga) crustal growth of the North China Craton revealed by zircon Hf isotope: A synthesis. Geoscience Frontiers 3, 147-173.

Zegers, E.T., van Keken, P.E., 2001. Middle Archean continent formation by crustal delamination. Geology 29, 1038-1086.

Zhao, G.C., Suna, M., Simon, A.W., Sanzhong, L., 2004. Paleo-Mesoproterozoic supercontinent: assembly, growth and breakup. Earth Science Reviews 67, 91-123. 


\title{
5. ARTIGO CIENTÍFICO 3:
}

\section{STATHERIAN TO CALYMINIAN MAGMATISM IN THE ALTO MOXOTÓ TERRANE, BORBOREMA PROVINCE, NE BRAZIL: IMPLICATIONS FOR WITHIN PLATE AND COLLISION TECTONICS IN WEST GONDWANA.}

Lauro Cézar Montefalco de Lira Santos ${ }^{1,2, *}$; Geysson Almeida Lages ${ }^{3}$; Elton Luiz

Dantas $^{1}$; Roberta Galba Brasilino ${ }^{3}$; Peter A. Cawood ${ }^{4}$; Joseneusa Brilhante Rodrigues ${ }^{3}$

${ }^{1}$ Instituto de Geociências, Universidade de Brasília, Brazil; ${ }^{2}$ Unidade Acadêmica de Mineração e Geologia, Universidade Federal de Campina Grande, Brazil; ${ }^{3}$ Serviço Geológico do Brasil - CPRM, Brazil; ${ }^{4}$ Department of Earth Sciences, University of St. Andrews, UK

*Corresponding author. E-mail: lauromontefalco@gmail.com

\begin{abstract}
In this study we present whole-rock geochemistry and isotopic data of metaplutonites located in the Paleoproterozoic Alto Moxtó Terrane of the Borborema Province, NE Brazil. They were emplaced on the Statherian-Caliminian transition (ca. 1.6 Ga), during a crust reworking episode. The Carnoió Suite occurs in within the terrane is characterized by slightly deformed syenogranites to qtz-syenites, presenting geochemical signature typical from magmas generated in a within-plate tectoinc setting. The associated geochemical signature. In contrast, rocks from the Riacho do Navio and Coloete units occur in the northern border of the terrane ands are share similar petrographic and geochemical characteristics, varying from granodiorites and syenogranites in composition. Geochemical data, including REE signature, point out to an arc-related to syn-collisional-related magmatism. The generation of A-type granites in this period is common in some areas of the Borborema Province as well as in its African counterpart, resulting from a major event of global continental break-up. However, subduction-related magmas of this age is scarce in the region, and described worldwide as part of peripheral convergence during coeval fragmentation of cratonic blocks. Our results suggest that the Alto Moxotó Terrane was part of an ancient block
\end{abstract}


that experienced subduction in its border, thus representing an exotic Paleoproterozoic fragment within the Neoproterozoic Borborema Province.

Key-words: Statherian-Caliminian transition; within-plate magmatism; subductiorelated magmatism TTG; peripheral orogenesis, Borborema Province.

\subsection{Introduction}

The episodic assembly and break-up of continents played a crucial role in crust and mantle evolution throughout earth's history as well as provided substantial changes for climate and life development (Santosh and Zhao, 2009; Hawkesworth et al., 2010; Condie, 2011; Nance and Murphy, 2013). Convergence of large landmasses involve a complex network of geological processes, leading to continental growth via addition of juvenile crust by arc-related magmas on subduction zones, which is frequently followed by crustal anatexis during continental collision (Pearce, 1982; Rapp and Watson, 1995). In contrast, rupture of preexistent crust followed by the opening of ocean basins constitute one of the major consequences of continental break-up and taphrogenesis (Zhao et al., 2004; Condie, 2011 and references therein).

Peak compilation of isotopic data indicate that the major Pre-Pangean landmasses/supercontinents were assembled in Late Mesoproterozoic to Neoproterozoic (ca. 1.3-0.9 Ga), Paleoproterozoic (ca. 2.0-1.8 Ga) and in the Neoarchean (ca. 2.5-2.7 $\mathrm{Ga}$ ), being termed Rodinia, Columbia and Ur/Kenorland, respectively (Rogers and Santosh, 2002; Zhao et al., 2002; Bleeker, 2003; Evans, 2003; Hawkesworth et al., 2009; Meert, 2012). Nuna and Atlantica are alternative suggested names for the major Paleoproterozoic supercontinent Columbia (Meert, 2012 and references therein). Preserved crustal segments formed during Rodinia assembly are presented in MesoNeoproterozoic belts worldwide, including those remnants of Grenville orogen in the Canadian Shield, Irumide belt in the Congo Craton and Sibao orogen in South China (Li et al., 2008 and references therein). However, Paleoproterozoic orogenic belts related to Columbia are widespread and disrupted in several cratonic blocks, including the TransHudson orogen in the Canadian Shield, Capricon orogen in western Australia, TransNorth China Belt in the North China Craton and Transamazonian belts in South 
America (Condie, 2002; Corrigan et al., 2009; Rogers and Santosh, 2009; Brito Neves 2011 and references therein).

In most cratonic blocks, the Paleo-Mesoproterozoic transition, rock record is related to initial break-up events around ca. 1.6 and 1.5 Ga (Zhao et al., 2004; Evans and Mitchell, 2011). Nevertheless, Late Paleoproterozoic subduction-related and collisional rocks compose several peripheric orogenic areas that might are coeval with cratonic blocks fragmentation. For instance, the 1.7-1.6 Ga Labradorian orogen in Laurentia (Rivers, 2012), 1.6-1.5 Gothian orogen in Baltica (Windley, 1992; Åhäll and Connely, 1998) and Ross orogen in Antarctica (Goodge et al., 2004) record significant accretionary episodes. In South America, the best known example of Paleomesoproterozoic accretionary orogen is the 1.8-1.5 Ga Rondonian-Juruena province in the Amazonian Craton (Tassinari and Macambira, 1999; Rizzotto and Quadros, 2005; Cordani et al., 2000). In spite of their restricted occurrence, such belts are particularly important for global reconstructions, once that they might be represented by Paleoproterozoic exotic terranes or basement inliers within younger structural provinces (Reddy and Evans, 2009).

Located in the central portion of the Neoproterozoic Borborema Province (BP), the Transversal Sub Province comprise a series of domains/terranes roughly displayed eastward that are part of an extensive Neoproterozoic active continental margin in the central part of West Gondwana (Santos and Medeiros, 1999; Brito Neves et al., 2000). Long-lived Paleoproterozoic magmatic and supracrustal rock assemblages are described in the region, including wide occurrences of Rhyacian to Orosirian intermediate subduction-related granitic and metagranitic units, especially in the Alto Moxotó Terrane (Neves et al. 2015; Santos et al., 2015) Nevertheless, Late Paleoproterozoic associations are punctual, being restricted to some anorthositic, metagranitic and bimodal rock associations, interpreted as the result of extensional-related magmatism (Brito Neves et al., 1995; Accioly, 2000; Sá et al., 2002, 2016; Santos et al., 2015).

In this sense, this paper aims to present laser ablation-multi-collector-inductively coupled plasma-mass spectrometry (LA-MC-ICP-MS) U-Pb in zircon, Sm-Nd and whole-rock geochemical data of recently discovered coeval collision- and within-plate Statherian-Caliminian metaplutonites in the Alto Moxotó Terrane of the BP. 
Considering these new data, we intend to contribute to the geodynamic evolution of the Paleo-Mesoproterozoic transition of this portion of West Gondwana.

\subsection{Geological setting}

\subsubsection{Borborema Province}

The Borborema Province was defined by Almeida et al. (1981) as a Neoproterozoic crustal segment that occupies most of the northeastern portion of the South American platform. This province belongs to a large and complex orogenic system located in the central portion of the West Gondwana (Figures 5.1a, 5.1b) that finds continuity in the Pan-African fold-belts between Togo to the north and Cameroon to the east through Central Africa (Brito Neves, 1975; Trompette, 1994; Van Schmus et al., 2008).

It is characterized by a complex geologic framework including Paleoproterozoic units and local exposures of Archean Nuclei, which are composed by orthogneissic and migmatitic complexes as well as greenstone-like sequences related to accretion-related events (Brito Neves et al., 2000; Santos et al., 2000; Fetter et al., 2003; Van Schmus et al., 2008; Dantas et al., 2013; Brito Neves, 2011), as well as several Neoproterozoic terranes/domains including supracrustal sequences as well as magmatic arc-related rocks including wide granitic magmatism related to the Cariris Velhos and Brasiliano orogenies (Santos and Medeiros, 1999; Santos et al., 2010; Oliveira et al., 2010; Caxito et al., 2014; Araújo et al., 2014a,b; Lages and Dantas 2016; Brito Neves et al., 2016, in revision). Complementing the Borborema Province framework, there is a complex network of large crustal strike-slip shear zones, mostly of them with regional expression, mainly formed by up to several kilometers-wide mylonitic corridors and sutures zones (Vauchez et al., 1995; Archanjo et al., 2008; Cordani et al., 2013).

The BP is divided into tectonic Sub provinces from north to south: Médio Coreaú, Ceará Central, Rio Grande do Norte, Transversal and Southern (Van Schmus et al., 1995, 2008; Santos and Medeiros, 1999; Brito Neves et al., 2000). In addition, based on detailed structural analysis and isotopic data, these authors suggested that this province was subjected to a polycyclic tectonic evolution involving several episodes of accretion and collage of tectono-stratigraphic terranes during the Neoproterozoic. 
However, some authors have challenged the accretion model, pointing out the significant role of the intracontinental deformation on the Neoproterozoic configuration of the province (Neves et al., 2006; Neves 2015). In this sense, the origin and evolution of this segment of the South America Platform is still a matter of intense debate.

Within the Transversal Sub province, five main terranes are recognized, being limited by important shear zones: São José do Caiano (SJC), Piancó-Alto Brígida (PABT), Alto Pajeú (APT), Alto Moxotó (AMT) and Rio Capibaribe (RCT) (Santos and Medeiros, 1999; Brito Neves et al., 2000). According to these authors the crustal segments record contrasting geological features, such as geophysical characteristics, structural geometry and kinematics, besides distinct petrogenetic associations in nature and ages, which are typical from accretionary processes. 


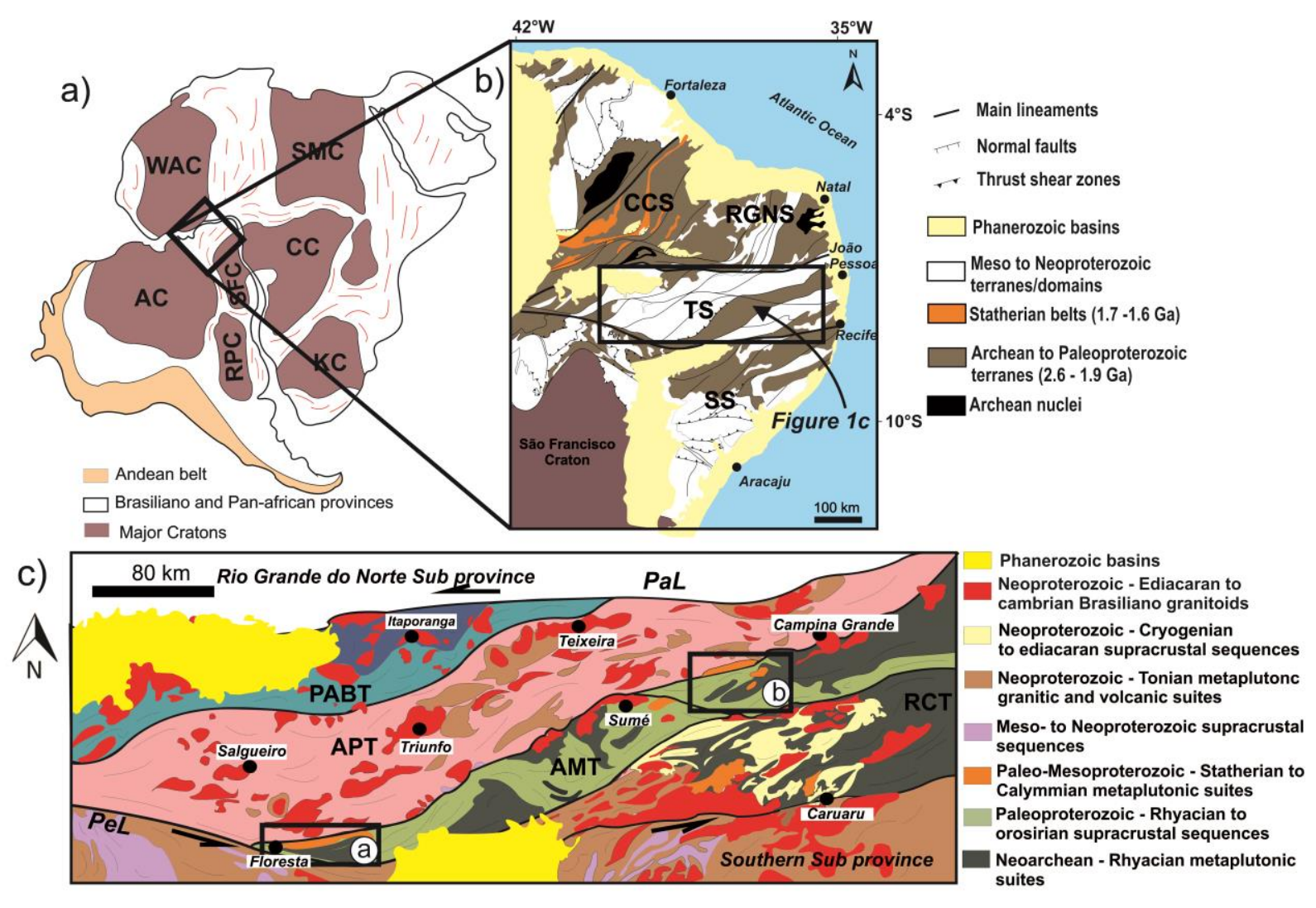

Figure 5.1 - a) Geodynamic context of the Borborema Province in Pre-Drift reconstruction of part of West Gondwana; b) Main geological subdivision of the Borborema Province and its main geological Sub provinces; c) Terranes of the Transversal Sub Province. Rectangles $a$ and $b$ represents Figures $2 a$ and $2 b$, respectively. Cratons: $\mathrm{AC}=$ Amazonian, $\mathrm{SFC}=$ São Francisco, $\mathrm{RPC}=$ Rio de La Plata, $\mathrm{WAC}=$ West Africa, $\mathrm{SMC}=$ Saara Metacraton, $\mathrm{CC}=$ Congo, $\mathrm{KC}=$ Kalahari . Borborema Sub provinces: $\mathrm{CCS}=$ Ceará Central, RNS $=$ Rio Grande do Norte, $\mathrm{TS}=$ Transversal, SS = Southern. Terranes of the Tranversal Sub Province: PABT = PiancóAlto Brigída, APT = Alto Pajeú, AMT = Alto Moxotó, RCT = Rio Capibaribe.

\subsubsection{The Alto Moxotó Terrane}

The Alto Moxotó Terrane is interpreted as a Paleoproterozoic basement inlier or exotic terrane that occurs within the Neoproterozoic Transversal Sub province (Brito Neves et al., 2001; Santos et al., 2004). It corresponds to a high-grade metamorphic block mainly composed of Rhyacian to Orosirian metaplutonic suites, including metagranites, orthogneisses, migmatites and mafic-ultramafic rocks which is surrounded by Rhyacian supracrustal sequences and metacarbonatic rocks related to 
Paleoproterozoic collisional events (Santos et al., 2015 and references therein). Structurally, this terrane is bounded to the north by the Alto Pajeú Terrane, a series of Tonian (ca. $1.0 \mathrm{Ga}$ ) thrust-related metaplutonic and metavolcanic rocks (Santos, 1995; Santos and Medeiros, 1999), whereas its southern limit is represented by the strike-slip Pernambuco lineament and the Congo-Cruzeiro do Nordeste shear zone (Brito Neves et al., 2001).

The evolution of continental crust within this terrane has been recently addressed by Santos et al. (2015), whom defined three major tectono-magmatic events for its evolution. The first one was responsible for the emplacement of intermediate metaplutonic rocks with a magmatic arc-related signature, which are siderian in age with juvenile and crustal characteristics. The second event is represented by granodioritic to tonalitic gneisses and mafic-ultramafic magmatism, also in a subduction-related setting, but with a stronger crustal signature at $2.1-2.0 \mathrm{Ga}$. This event was responsible for multiple sheet-like intrusions that are widespread throughout the terrane. Additionally, an important 1.97-1.95 Ga age high-grade metamorphic event and collisional magmatism was noted by Neves et al., (2015), which is possibly related to eclogite to granulite transition described in the region. Lastly, within-plate bimodal magmatism with an age at ca. $1.6 \mathrm{Ga}$ represents the third magmatic pulse of the AMT. In time, Neoarchean TTG suite has been recently described (Santos et al., 2016, in revision), indicating that the pioneer events of crustal growth of the AMT is possibly older than that one previously thought.

\subsubsection{Field aspects and petrography of the studied suites}

The studied rocks occur in the northern border and central portion of the Alto Moxotó Terrane, being spaced by several kilometers (Figures 5.1 and 5.2). In the vicinity of the Airí Town (southwestern portion of terrane) rocks of the Riacho do Navio Suite outcrops. They form nearly E-W elongated and fold bodies, which are concordant with regional Brasiliano-related structural trending. In addition, this suite is in tectonic contact with the Riacho das Lajes Neoarchean TTG suite. They vary from intrusive sheets of metagranitoids or discretely banded orthogneisses (Figure 5.3a), to highly deformed rocks, including proto-mylonites and augen gneisses (Figure 5.3b). In 
general, they have coarse-grained to porphyroblastic texture, exhibiting phenocrysts of potassic feldspars varying from 1.5 to $6 \mathrm{~cm}$.

In thin section, these rocks correspond mainly to monzo to syenogranites, but quartz-monzonite, quartzo-diorites, granodiorites and tonalites are also present in a minor extent (Figure 5.4). In most of the studied samples, they show the effect of penetrative deformation, being characterized by granoblastic texture (Figure 5.5a) as well as developing quartz-ribbons with undolose extinction, typical from high strain conditions. In addition, the groundmass is characterized by irregular to polygonal intergranular contacts. The main mineralogy is composed by anhedral to subhedral quartz and subhedral mycrocline and plagioclase crystals. Brown to reddish biotite lamellae corresponds to the main mafic phase, whereas muscovite crystals are restricted to intergranular contacts of quartz and feldspar. In a few situations, a greenish hornblende crystals took part of the studied samples, corresponding to the main mafic phases. Apatite, zircon and pyrite correspond to the main accessory minerals, while the presence of greenish to bluish chlorite was interpreted as the result of biotite alteration.

The Coloete orthogneiss occur as east-west-striking, locally garnet bearing rocks that crop out in the northeastern part of the Boa Vista Town (northeast portion of the Alto Moxotó Terrane; Figure 5.2). Variations from mylonites, banded gneisses and tabular sheets are common. Medium-grained leucocratic rocks are the most common facies. Petrographic analysis revealed that most of the samples correspond to monzogranites with some scattering to granodiorites. Quartz ribbons and syn-tectonic garnets are oriented according to the main foliation strike. In addition, recrystallized oligoclase and microcline crystals are involved in an augen fabric, whereas biotite is the major mafic mineral and chlorite is the major products of its destabilization.

Lastly, the Carnoió Suite is composed by northeast trending orthogneisses with homogeneous to metatexite characteristics ranging between granite to syenogranitic compositions. Minor terms likewise alkali-granites and quartz-syenitic variations are also recognized. They are situated in northeastern portions of the Alto Moxotó Terrane, being intrusive on Ryacian orthogneisses (Figure 5.3e) and supracrustal rocks, collectively known as Cabaceiras Complex as well as closely associated with metanorthosites. In general, they have pinkish to greenish gray, medium-grained, granoblastic and porphyroblastic textures with conspicuous tectonic foliation (Figure 
5.3f), characterized by deformed amphinole, biotite and garnet crystals. The main mineralogy is composed by microcline with meso-perthitic exsolutions, plagioclase, quartz, hastingsite hornblende and biotite. Accessory minerals include garnet, allanite, titanite, apatite, zircon and opaque minerals.

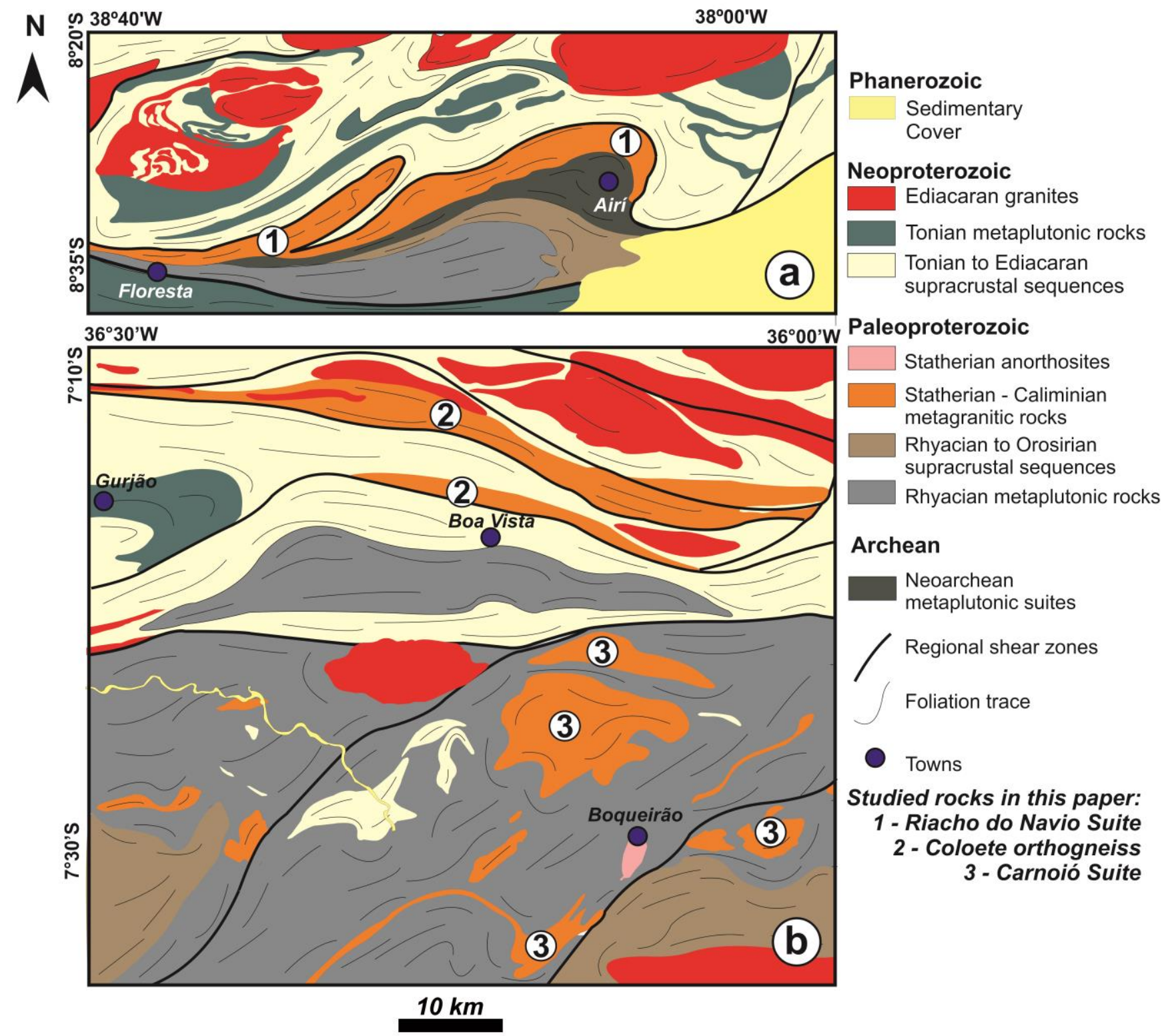

Figure 5.2 - Simplified geological maps of the studied areas with the occurrences of the Riacho do Navio Suite, Coloete orthogneiss and Carnoió Suite. 

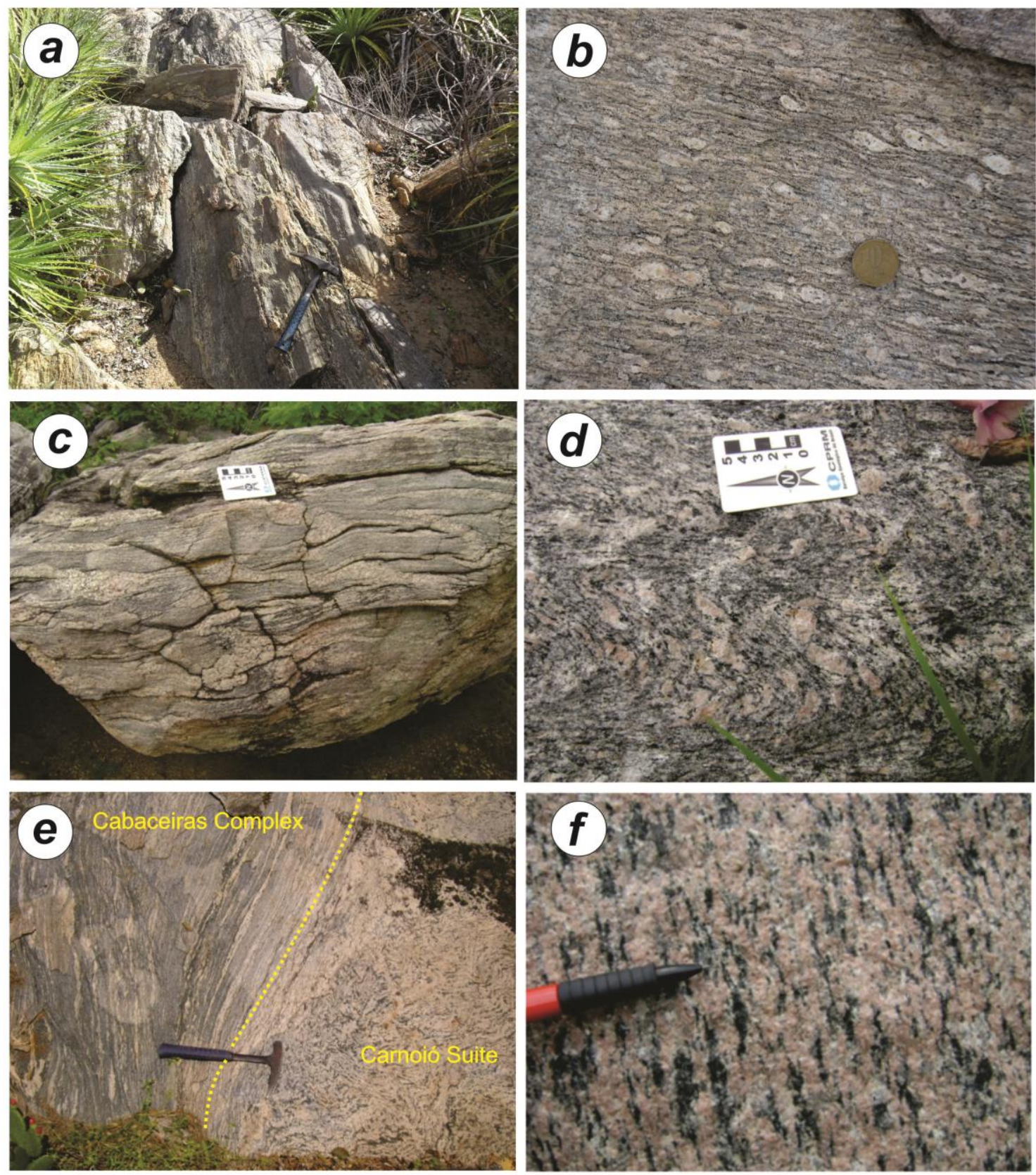

Figure 5.3 - Field aspects of the studied rocks. a) Metagranitic sheet of the Riacho do Navio Suite; b) augen gneiss facies of the Riacho do Navio Suite exhibiting eye-shape potassic feldspar up to $1,5 \mathrm{~cm}$; c) granitic gneiss fabric of the Coloete orthogneisses; d) Banded orthogneiss to mylonites from Coloete orthogneisses; e) intrusive contac between metatexites of the Carnoió Suite on the right side of the photo and early Paleoproterozoic banded to migmatized granitic gneiss of the Cabaceiras Complex; f) amphibole bearing alkali-feldspar syenogranitic orthogneiss of the Carnoió Suite. 


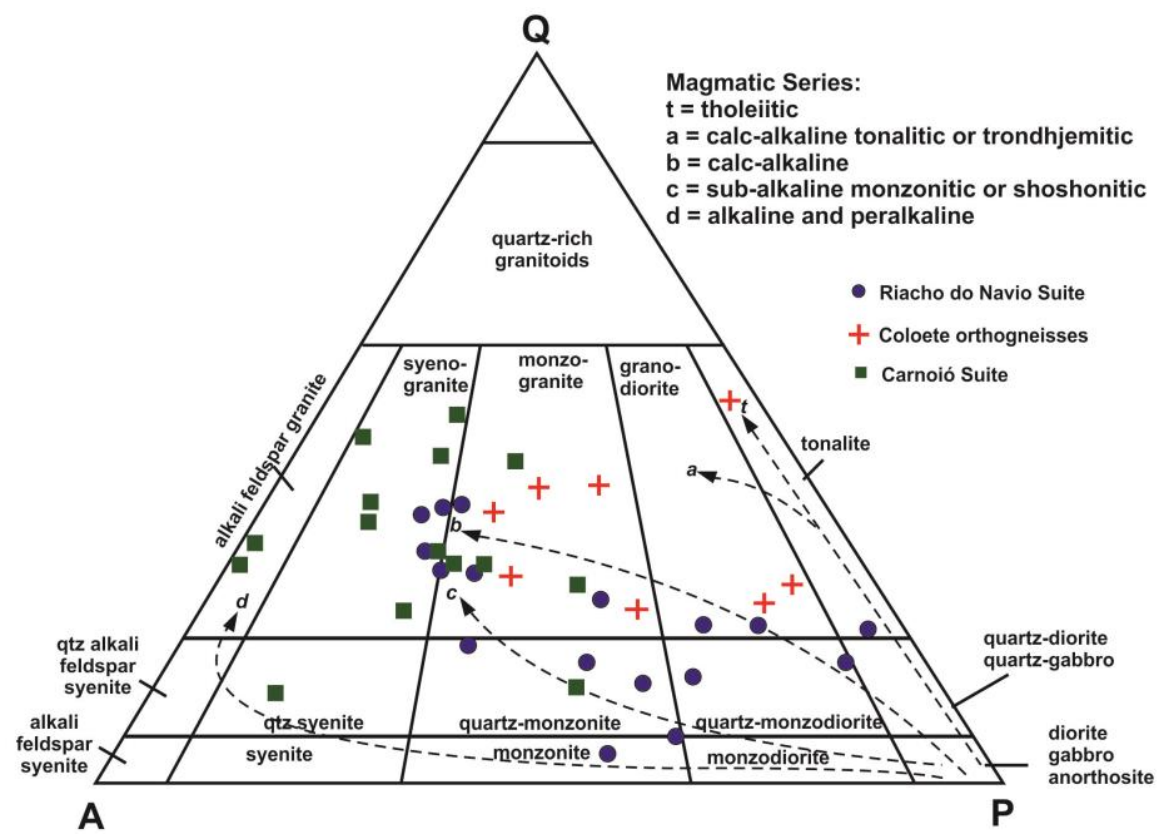

Figure 5.4 - Modal composition of studied rocks reported in the Q-A-P triangle diagram from Streckeisen (1976).

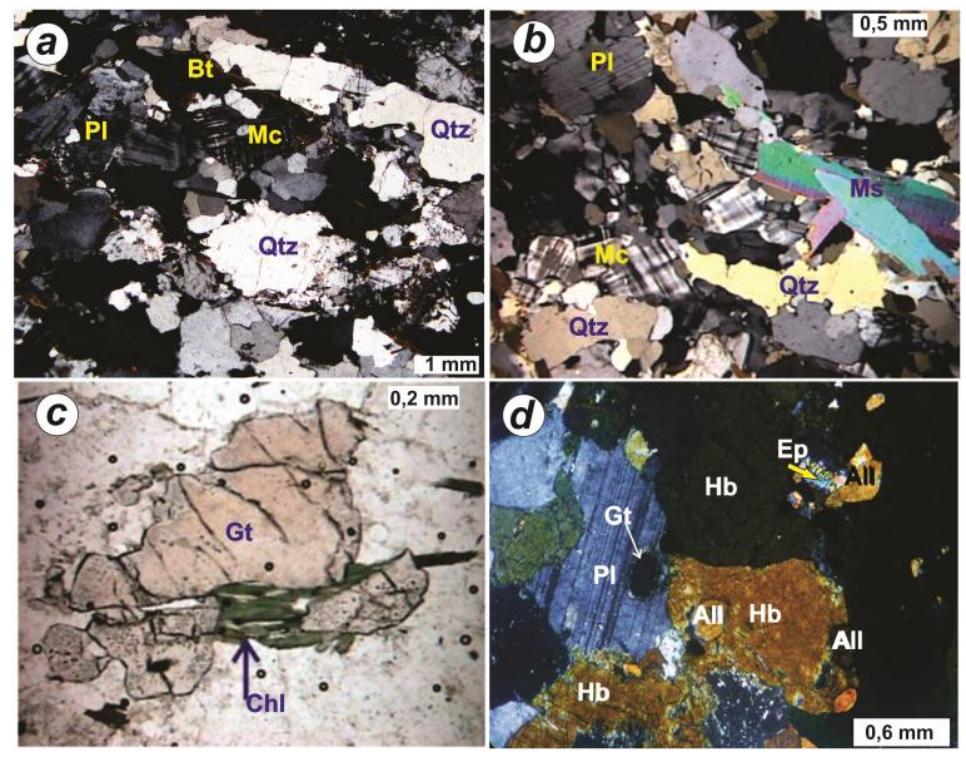

Figure 5.5 - a) Granoblastic texture in metasyenogranitic rock of the Riacho do Navio Suite exhibiting oriented quartz ribbons as a result of intense deformation; b) Coloete orthogneiss with crystals of microcline, plagioclase and stretched quartz. Muscovite lamellae is also present. c) fractured syn-tectonic garnet exhibiting chlorite substitution of the Coloete orthogneisses; d) epidotization in amphibole aggregates with allanite inclusion. Garnet occur englobed by plagioclase in syenogranites of Carnoió Suite. 


\subsection{Analytical procedures}

Three samples, one for each studied unit, were selected for zircon $\mathrm{U}-\mathrm{Pb}$ age dating at the Geochronology Laboratory of University of Brasília, Brazil. The samples were initially crushed and sieved, and then the heavy minerals were separated using conventional gravimetric and magnetic methods. Zircon grains were then hand-picked using a binocular microscope and mounted on epoxy resin for LA-MC-ICP-MS isotope ratio acquisition. The data reduction was performed following Bühn et al. (2009) and Matteini et al. (2009). The isotopic analyses were performed on a Mass spectrometer (Finnigan Neptune, Thermo Scientific, NYSE:TMO) with ICP equipped with a secondary electron multiplier-ion counter. Only coherent interval analyses were chosen to avoid signal mixed ages. Normalization was performed with internal GJ standard zircon (608.5 $\pm 1.5 \mathrm{Ma}$; Jackson et al., 2004), and the age calculations were performed using Excel spreadsheets developed in-house. Back-scattered images were used to investigate the internal structures of individual zircon crystals prior to each analysis in order to choose potential targets.

For the Sm-Nd data, an aliquot of fourteen samples from the Riacho do Navio Suite and Carnoió Suite as well as the Coloete orthogneisses, both analyzed following the method described by Gioia and Pimentel (2000). Whole rock powders (ca. $50 \mathrm{mg}$ ) were mixed with a ${ }^{149} \mathrm{Sm}^{-}{ }^{150} \mathrm{Nd}$ spike solution and dissolved in Savillex capsules. The extraction of $\mathrm{Sm}$ and $\mathrm{Nd}$ from whole-rock samples followed conventional cation exchange techniques using Teflon columns containing LN-Spec resin (HDEHP diethylhexyl phosphoric acid supported on PTFE powder). The Sm and $\mathrm{Nd}$ samples were loaded on Re evaporation of double-filament assemblies, and the isotopic measurements were performed on a MS (Triton Plus, Thermo Scientific) at the University of Brasília.

The uncertainties in the $\mathrm{Sm} / \mathrm{Nd}$ and ${ }^{143} \mathrm{Nd} /{ }^{144} \mathrm{Nd}$ ratios are better than $\pm 0.4 \%$ (1 $\sigma)$ and $\pm 0.005 \%(1 \sigma)$, respectively, based on repeated analyses using the international rock standards Basalts Hawaiian Volcanic Observatory (BHVO-1), and Columbia River (BCR-1). The ${ }^{143} \mathrm{Nd} /{ }^{144} \mathrm{Nd}$ ratios were normalized to a ${ }^{146} \mathrm{Nd} /{ }^{144} \mathrm{Nd}$ of 0.7219 , and the used decay constant was $6.54 \times 10^{-12}$. $\mathrm{T}_{\mathrm{DM}}$ model age values were calculated using the DePaolo (1981) model. 
In addition, twenty seven representative samples of the studied suites were analyzed for major and trace elements at Acme Analytical Laboratories Ltd. (Canada), including seven from the Riacho do Navio Suite, eight from the Coloete orthogneiss and twelve from the Carnoió orthogneiss. Major elements were determined by ICP- atomic emission spectrometry (ICP-AES), with a detection limit of $0.01 \%$ and precision of \pm $0.1 \%$. The trace and rare earth elements were analyzed by ICP-MS, with detection limits between 0.01 and $0.5 \mathrm{ppm}$ and a precision of $\pm 5 \%$. The geochemical diagrams were constructed using the Igpet 06 software, GCDkit, Petrograph, Minpet and Excel datasheets.

\subsection{Results}

\subsubsection{LA-MC-ICP-MS U-Pb zircon dating}

Three representative samples were selected for $\mathrm{U}-\mathrm{Pb}$ zircon dating, one for each studied unit and the obtained results are present in tables 1, 2 and 3. Sample FL 122 is a pinkish metasyenogranite of the Riacho do Navio Suite. Most of analyzed zircon grains from this sample are euhedric to subhedric sizing between 150 and $200 \mu \mathrm{m}$. They are mainly colorless to grayish, present prismatic to rounded shape. The internal structure revealed by backscattering images show oscillatory zoning and spongy textures at the rims, probably due to metamictization. The oscillatory zoning is a typical feature of magmatic zircon (Figure 5.6a), what is endorsed by $\mathrm{Th} / \mathrm{U}$ which are mostly $>$ than 0.1 . Fragmented or absorbed rims may be also present in some grains. The data of five zircon grains plot along a discordia line, that yields an upper and low intercept age of $1611 \pm 78 \mathrm{Ma}(\mathrm{MSWD}=5.1)$. Although the large error, and poor quality of the data, this is interpreted as the best estimate for age crystallization of the igneous protolith. (Figure 5.6b).

Zircon grains from a Coloete granite-gneiss (sample GL-510) mostly preserve very well the prismatic habit and faces (Figure 5.6c), besides minor fractures. The backscattering images reveal discrete oscillatory zoning, local recrystallization and preserved homogeneous areas as well. Analyzes were conducted on all kinds of texture and they present $\mathrm{Th} / \mathrm{U}$ varying from 0.19 to 0.60 . Of twenty four points analyzed, the thirteen data were used to calculate the upper of $1650 \pm 23$ associated with MSWD of 
0.59, as shown in Figure 5.6d. This age may be considered as age of magma crystallization of Coloete orthogneiss. Despite the larger error, the low intercept may represent the thermal event related to Brasiliano Orogeny.

Lastly, sample RS-425 corresponds to a amphibole syenogranitic orthogneiss of the Carnoió Suite, which is characterized by elongated euhedric prismatic zircon grains, which may exhibit a complex pattern of oscillatory zoning and an average size of 200 $\mu \mathrm{m}$ (Figure 5.6e). U-Pb results for this sample define a discordia line with an upper intercept age of $1638 \pm 13 \mathrm{Ma}$ (21 analyses, $1 \sigma$; MSWD=0.31), being interpreted as the crystallization age of the protolith, which is slightly older than the previous samples (Figure 5.6f). The lower intercept age of $516 \pm 110 \mathrm{Ma}$ is interpreted as the result of $\mathrm{Pb}$ loss during the Brasiliano metamorphism that strongly affected this part of the Borborema Province. 

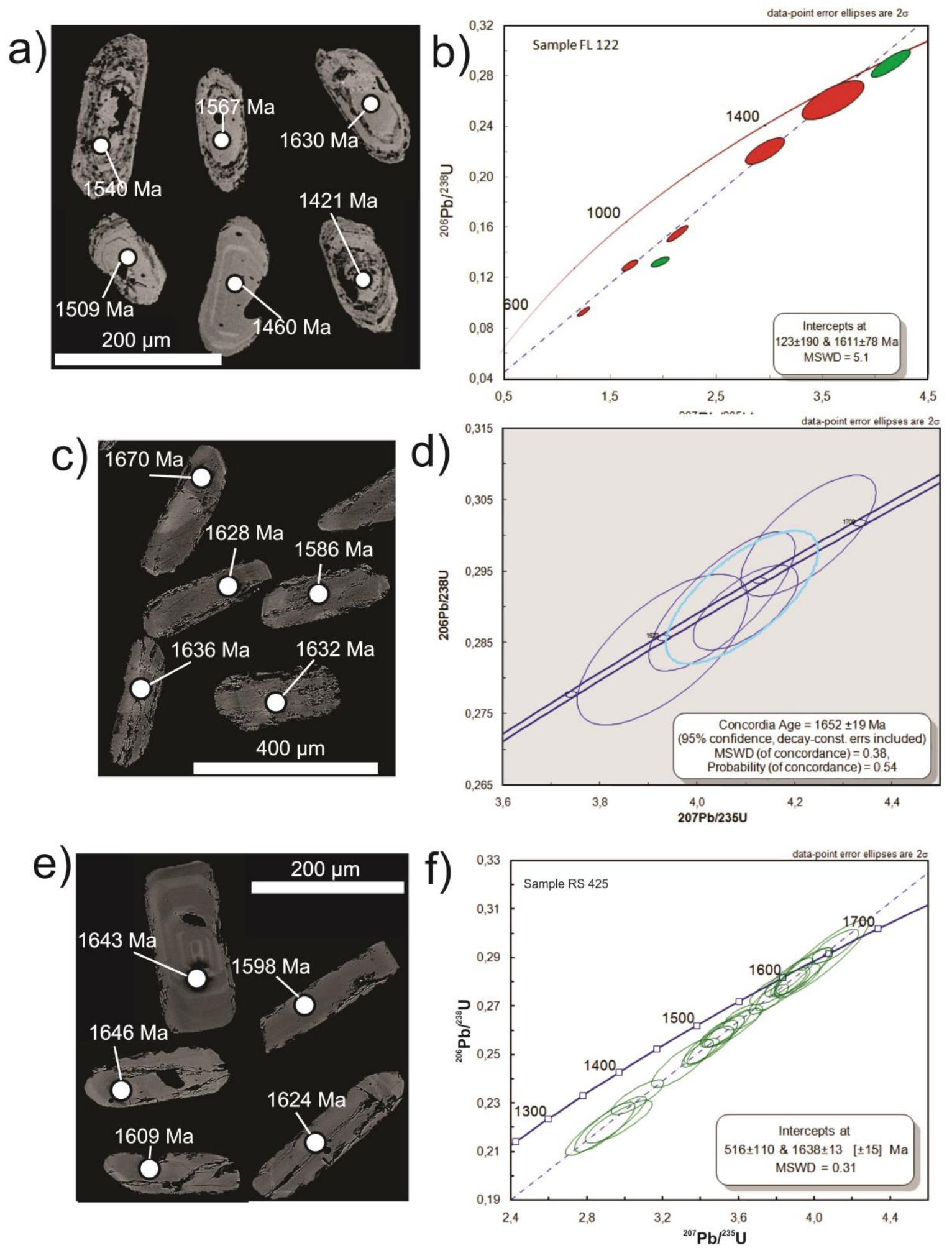

Figure 5.6 - Cathodoluminescence (a) and Backscattered images (c and e) of zircon grains where the white circles indicate the position of laser spots with their respectively ${ }^{207} \mathrm{~Pb} /{ }^{206} \mathrm{~Pb}$ ages and the diagrams of LA-MC-ICP-MS results of the three studied units (b, d and f). 


\subsubsection{Sm-Nd isotopes}

Sm-Nd analyses were performed on representative samples the studied rocks and the obtained results are present in table 4. In the case of the Riacho do Navio Suite, regardless of field and petrographic facies, all samples show similar isotopic characteristics, such as initial ${ }^{143} \mathrm{Nd} /{ }^{144} \mathrm{Nd}$ ratios, $\mathrm{T}_{\mathrm{DM}}$ and $\varepsilon \mathrm{Nd}$ values. They present $\mathrm{Nd} \mathrm{T}_{\mathrm{DM}}$ model ages ranging from 2.37 to $2.93 \mathrm{Ga}$, thus indicating Rhiacyan to Mesoarchean sources. $\varepsilon \mathrm{Nd}_{(\mathrm{t})}$ values are strongly negative between -6.88 and -15.25 (Figure 5.7a). On the other hand, analysis of two samples of Carnoió Suite (RS-120 and RS-486) pointed to these rocks $\mathrm{T}_{\mathrm{DM}}$ models ages between 2.65 and $2.81 \mathrm{Ga}$, with $\varepsilon \mathrm{Nd}$ values ranging from -11.32 and -6.67 (Figure 5.7b).
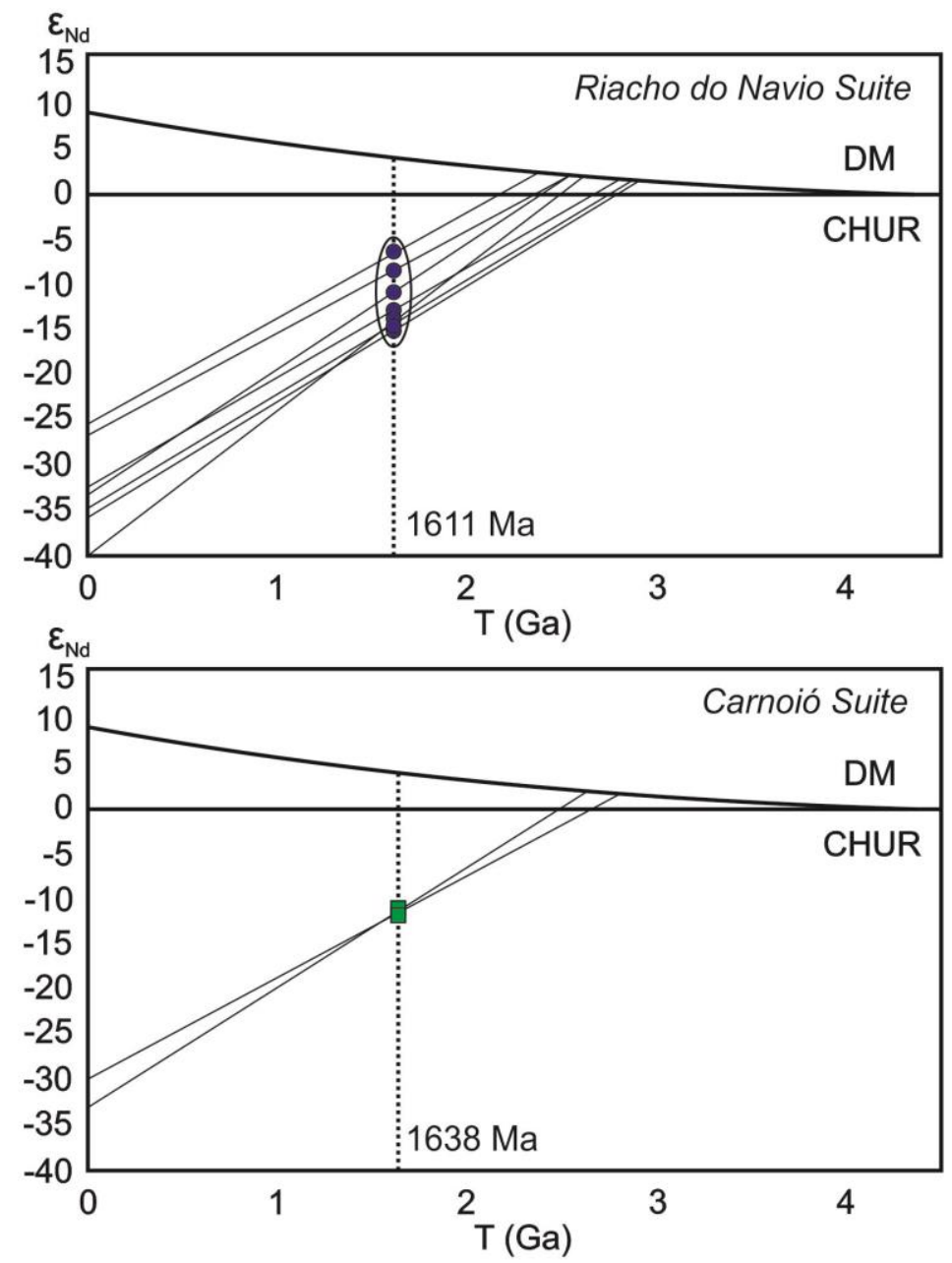

Figure 5.7 - Nd isotopic composition of analyzed samples of the Riacho do Navio and Carnoió suites. 


\subsubsection{Whole-rock geochemistry}

\subsubsection{Riacho do Navio Suite}

Chemically, the rocks from this suite present mainly granitic composition (Figure 5.8), being characterized by an acid character $\left(\mathrm{SiO}_{2}>67 \%\right)$. The studied samples plot in the calcic to alkali calcic on the modified Alkali-Lime index (MALI; $\mathrm{Na}_{2} \mathrm{O}+\mathrm{K}_{2} \mathrm{O}-\mathrm{CaO}$ ) vs. $\mathrm{SiO}_{2}$ diagram from Frost et al. (2001, Figure 5.9a). They are characterized by Fe\# ranging between 0.78 and 0.81 , thus plotting in the limit of ferroan to magnesian granites according to Frost et al. (2001) classification (Figure 5.9b). In the $\mathrm{Al}_{2} \mathrm{O}_{3} /\left(\mathrm{Na}_{2} \mathrm{O}+\mathrm{K}_{2} \mathrm{O}\right)$ molar vs. $\mathrm{Al}_{2} \mathrm{O}_{3} /\left(\mathrm{CaO}+\mathrm{Na}_{2} \mathrm{O}+\mathrm{K}_{2} \mathrm{O}\right)$ diagrams, the samples are characterized by a peraluminous character (Figure $5.9 \mathrm{c}$ ). The normalized spider diagram from these rocks present moderate to high contents of large-ion lithophile elements (LILE) related to high field strength elements (HFSE), presenting a strong positive anomaly of $\mathrm{Sr}$ beside the negative anomalies of $\mathrm{Nb}, \mathrm{Ta}, \mathrm{P}$ and $\mathrm{Ti}$ (Figure 5.10a).

The chondrite normalized rare earth elements (REE) diagram (Figure 5.10b) present a steep pattern, being characterized by moderate to high fractionation of lightREE (LREE) with respect to heavy-REE (HREE) (LaN/Yb $\mathrm{Yb}_{\mathrm{N}}$ ranging between 17.65 to 140.00), besides negative $\mathrm{Eu}$ anomaly $\left(\mathrm{Eu} / \mathrm{Eu}^{*}{ }_{\mathrm{N}}\right.$ ranging between 0.19 and 0.52$)$, which suggest fractionation of plagioclase in the source region. The composition of trace elements of rocks of the Riacho do Navio Suite is compatible with volcanic arcs-related granites (Harris et al., 1986, Figure 5.11a), whereas in the tectonic discrimination diagrams from Pearce (1984), they show chemical similarities with volcanic arc-related and syn to post-collisional granites (Figures $5.11 \mathrm{~b}$ and $5.11 \mathrm{c}$ ).

\subsubsection{Coloete Orthogneisses}

Similar to studied rocks of the Riacho do Navio Suite, samples from the Coloete orthogneisses are mainly silicic $\left(\mathrm{SiO}_{2}>69 \%\right)$ varying from granitic to granodioritic in composition (Figure 5.8). On the MALI vs. $\mathrm{SiO}_{2}$ diagram the samples plot on the calcalkali and alkali-calcic fields (Figure 5.9a).They are also characterized by wide range of Fe\# $(0.74-0.82)$, which correspond to transitional magmas between the ferroan and 
magnesian series $(\mathrm{Fe} \#=0.74-0.80$, Figure 5.9b). Additionally, analyzed orthogneisses present mainly peraluminous protoliths (Figure 5.9c).

Regarding the trace element signature, chondrite-normalized spider diagram present high contents on LILE ( $\mathrm{Ba}, \mathrm{Rb}$ and $\mathrm{K})$ with negative anomalies on HFSE, specially $\mathrm{Nb}$, Ta, $\mathrm{P}$ and $\mathrm{Ti}$, besides positive peaks on $\mathrm{Sm}$ and $\mathrm{Hf}$ (Figure 5.10c). REE pattern is characterized by enrichment of LREE with respect to HREE, without Eu anomaly (Figure 5.10d). In the tectonic discriminating diagrams, these orthogneisses corresponds to arc-related and syn-collisional granites (Figures 11a, 11b and 11c), confirming the observed anomaly pattern of the spiderdiagram.

\subsubsection{Carnoió Suite}

Studied samples of the Carnoió Suite ranges from intermediate to acid rocks $\left(\mathrm{SiO}_{2}>63 \mathrm{wt} . \%\right)$, corresponding to granitic to qtz-syenitic derivative magmas (Figure 5.8). They plot in the calc-alkali and alkali calcic fields on the MALI vs. $\mathrm{SiO}_{2}$ (Figure 5.9a). Fe\#>0.85 indicate that this samples shares similar geochemical characteristics with ferroan granites (Figure 5.9b) contrasting with the Riacho do Navio and Coloete units. Additionally, the studied samples correspond mainly to metaluminous magmas, with few samples showing a slightly peraluminous tendency (Figure 5.9c).

Chondrite-normalized spider diagram of the studied samples show a relatively uniform pattern, characterized by little enrichment on LILE and strong negative anomalies on $\mathrm{Sr}, \mathrm{P}$ and Ti. HFSE elements such as $\mathrm{Nb}$ and $\mathrm{Ta}$, are characterized by discrete negative anomalies (Figure 5.10e). Additionally, they show a relative enrichment in REE elements when compared to the previous units (Figure 5.10f). The pattern is flat to moderately fractionated with small enrichment on LREE with respect to HREE $\left(\mathrm{La}_{\mathrm{N}} / \mathrm{Yb}_{\mathrm{N}}\right.$ ranging from 7.25 to 19.8$)$ and discrete to strong Eu negative anomaly with $\left(\mathrm{Eu} / \mathrm{Eu}^{*}\right)_{\mathrm{N}}$ ranging between 0.36 to 0.51 .

Regarding the tectonic setting, on the triangular diagram proposed by Harris et al., (1986), the samples plot in the transition between volcanic-arc and within-plate granites (Figure 5.11a). Nonetheless they show a major tendency for the WPG field on Pearce et al., (1984) diagrams (Figures 5.11b and 5.11c). In addition, they plot entirely in the A2-type granitic field, following Eby (1992) diagram. 

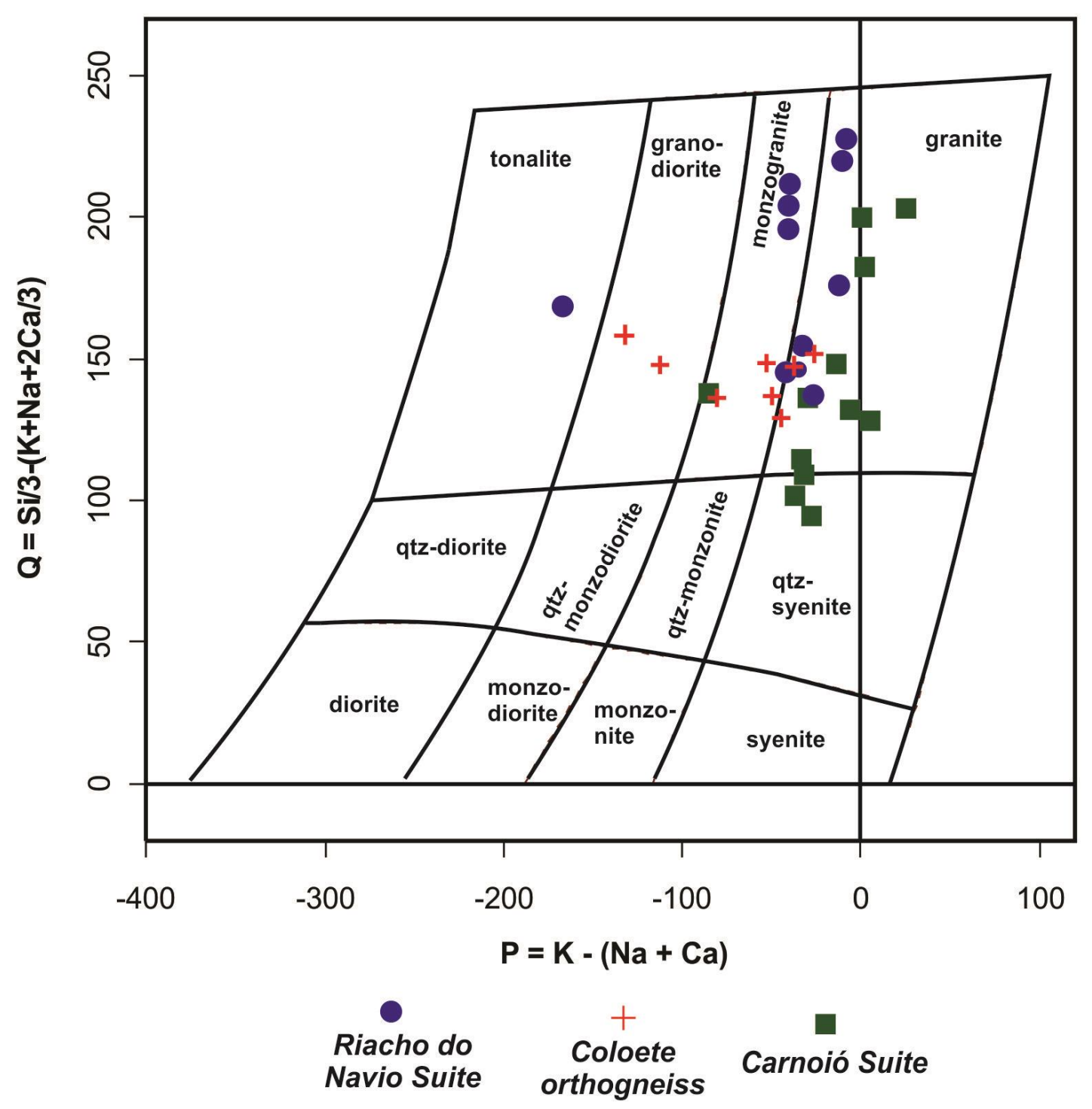

Figure 5.8 - Chemical classification of the studied rocks. Fields after Debon and Le Fort (1983). 

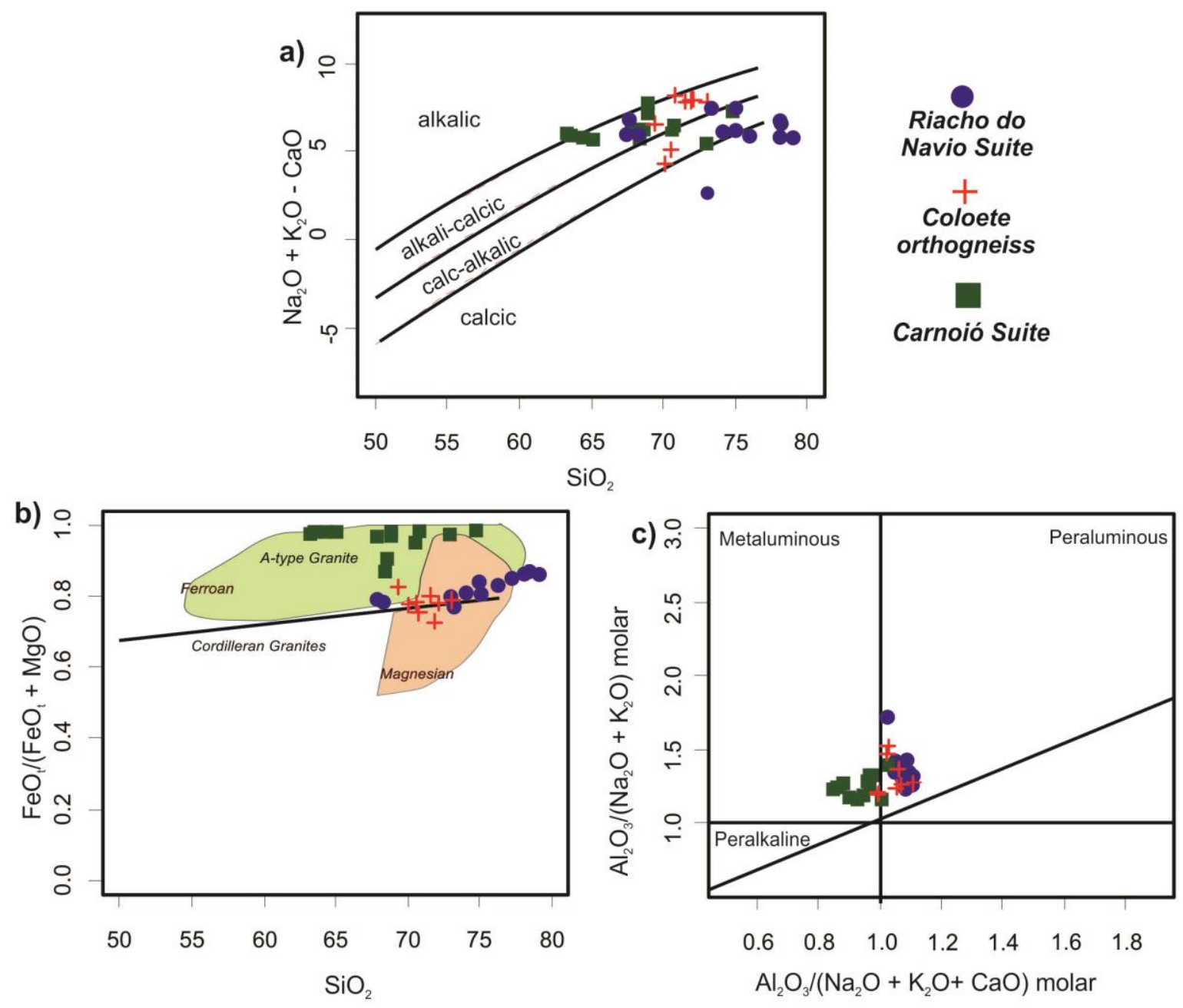

Figure 5.9 - Geochemical characteristics (major elements) of the studied rocks. a) $\mathrm{SiO}_{2}$ vs $\mathrm{Na}_{2} \mathrm{O}+\mathrm{K}_{2} \mathrm{O}-\mathrm{CaO}$ diagram from Frost et al., (2001); b) $\mathrm{SiO}_{2}$ vs. $\mathrm{FeO} /(\mathrm{FeOt}+\mathrm{MgO})$ diagram from Frost et al., (2001); c) $\mathrm{Al}_{2} \mathrm{O}_{3} /\left(\mathrm{Na}_{2} \mathrm{O}+\mathrm{K}_{2} \mathrm{O}\right)$ molar vs. Al2O3/(CaO+Na2O+K2O) molar diagram after Maniar and Picolli, (1980). 

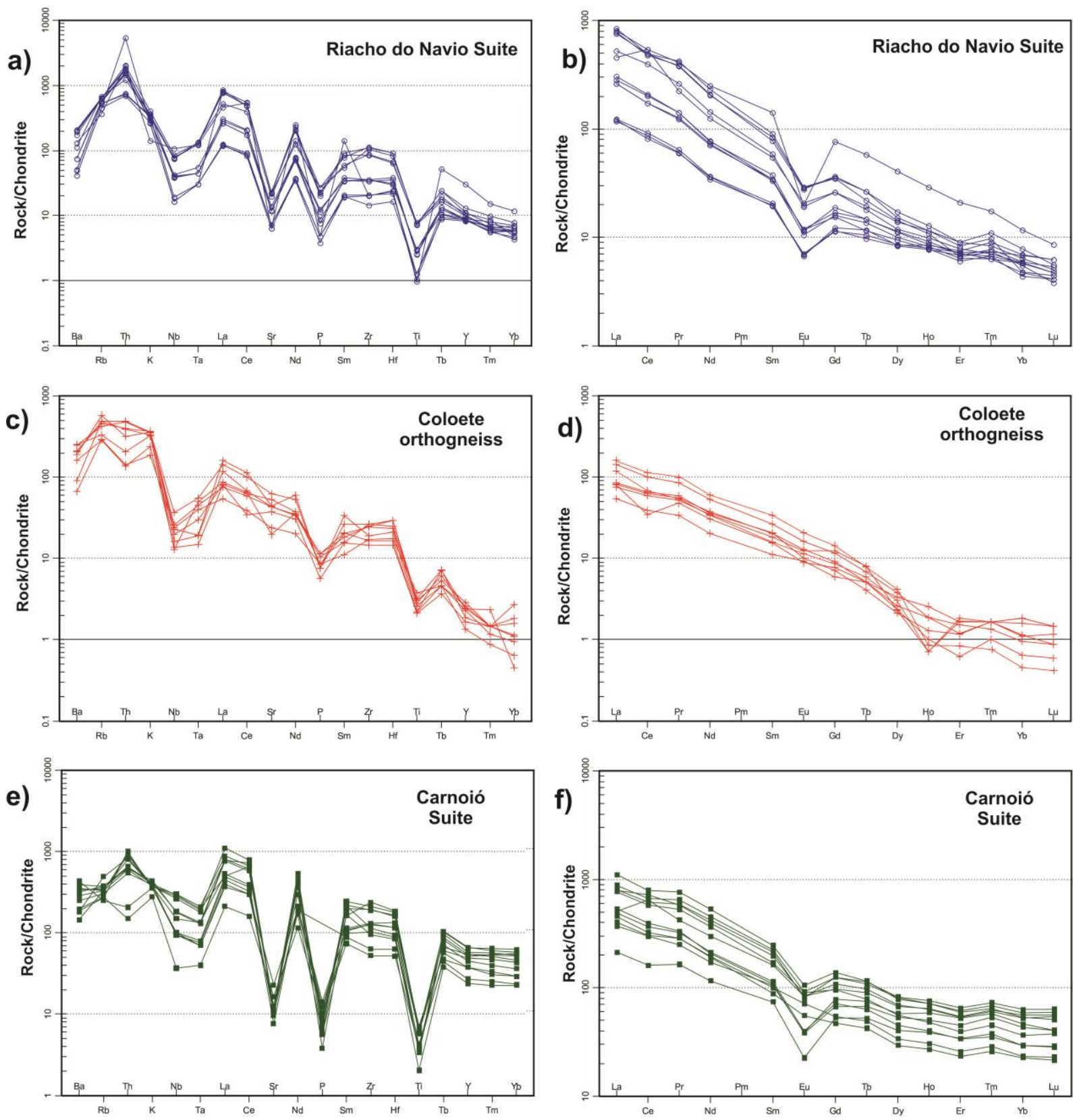

Figure 5.10 - Chondrite-normalized spider diagrams (Nakamura, 1974) and rare earth elements (REE) patterns (Thompson, 1982) of the studied units. 

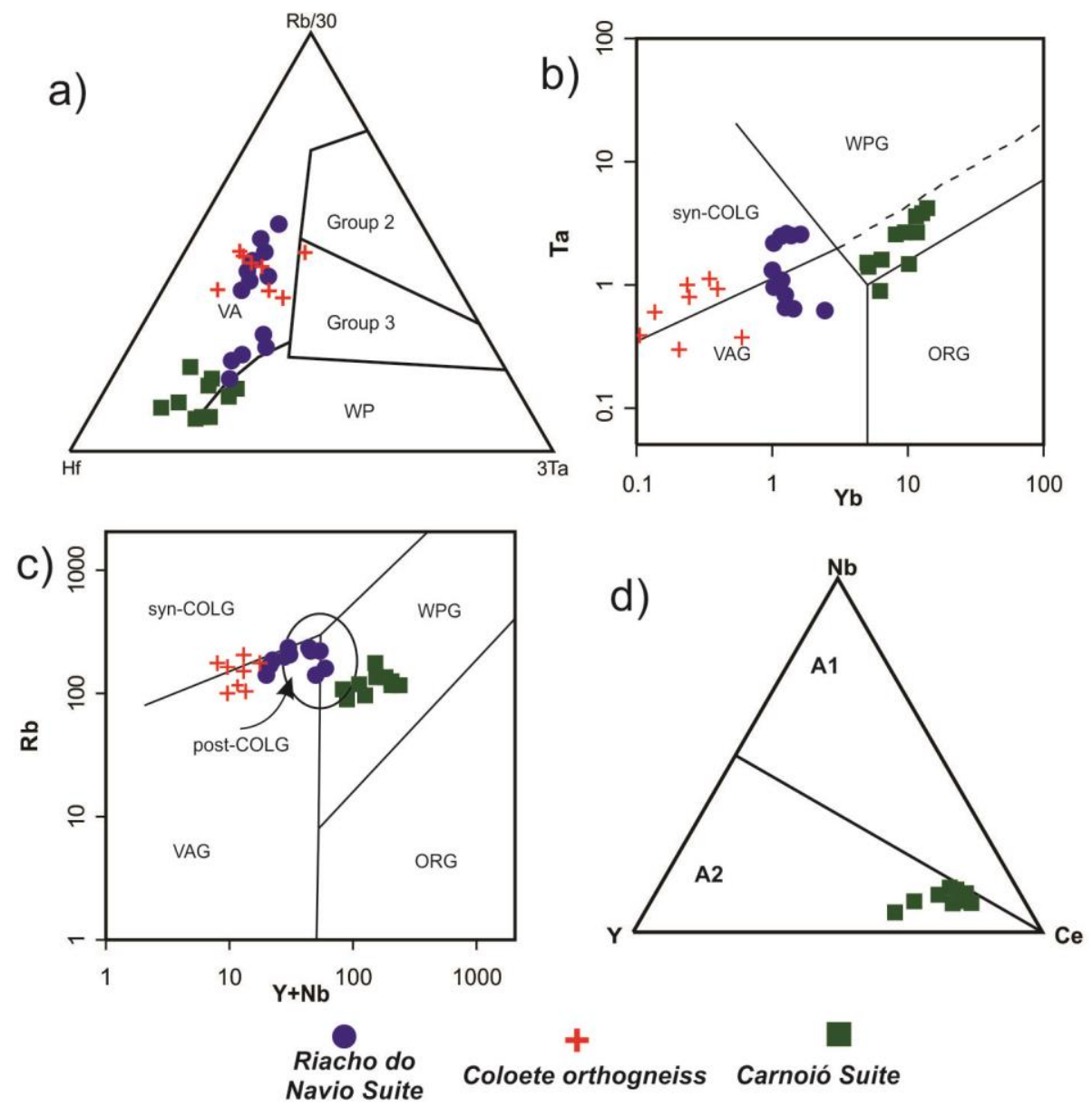

Figure 5.11 - Discriminating diagrams of the studied rocks. a) Rb-Hf-Ta plot from Harris et al., (1986); b) Yb vs. Ta and c) Y + Nb vs. Rb plots from Pearce et al., (1984); d) $\mathrm{Nb}$-Y-Ce plot of the A-type rocks from Eby, 1992 (A1 = mantle type, A2 = crustal type).

\subsection{Discussion}

\subsubsection{Age, sources and tectonic setting}

Detailed petrographic and geochemical data as well as U-Pb zircon ages and $\mathrm{Sm}-\mathrm{Nd}$ isotopic determinations on the studied rocks, allowed us to yield new tectonic constraints on the crustal evolution of the Alto Moxotó Terrane covering the StatherianCalymmian transition. This terrane is interpreted by several authors as a paleoproterozoic crustal inlier or exotic terrane (Brito Neves et al., 2000; Santos et al., 2004, 2015; Neves et al., 2015). The oldest recognized unit, corresponds to the Coloete orthogneissese, which are aged at ca. 1650 Ma. Younger ages were found in the Carnoió 
orthogneiss and metagranitic rocks of the Riacho do Navio Suite (ca. 1638 Ma and 1611 Ma, respectively). Considering the age errors, we consider their emplacement in the crust was coeval.

The Riacho do Navio Suite and Coloete orthogneisses are slightly similar on petrographic and geochemical aspects. They correspond mostly to augen-gneisses with potassic feldspar porphyroclasts and metagranitic rocks, whose composition varies from granodiorites to syenogranites. Both units mostly represent acid, alkali-calcic to alkalic, magnesian and peraluminous magmas. In addition, trace element distribution presents a relative enrichment of LILE in respect to HFSE, with $\mathrm{Nb}, \mathrm{Ta}, \mathrm{P}$ and $\mathrm{Ti}$ negative anomalies. However, in terms of REE, these units show distinct behavior, especially on the presence of Eu anomaly, typical from a placioclase-rich source. The observed geochemical parameters are suggestive of a subduction-related setting (Pearce, 1982; McMillan et al., 1989). Furthermore, tectonic setting discrimination diagrams demonstrate that these rocks plot in the magmatic-arc related and syn-collisional fields, thus corroborating with a convergent scenario.

Additional mineralogical and geochemical characteristics such as the presence of aluminous primary phases such as garnet and muscovite, besides the aforementioned geochemical aspects, including the peraluminous character of these units are similar to granitoids produced during continental collision (Barbarin, 1996, 1999) or S-type granites (Chappel, 1984; Chappel and White, 2001). The main attributed source for such associations generally involves a strong contribution of supracrustal rocks, including psamites and pelites (Stevens et al., 1997; Patiño-Douce and Harris, 1998). Migmatitic terranes are considered an ideal site for the generation of peraluminous granites, once that melt-extraction is commonly associated to a deformation-controlled source (Brown et al., 1995; Ayres and Harris, 1997; Davies and Tommasini, 2000). The Alto Moxotó Terrane is a typical gneissic-migmatitic terrane with variable occurences of supracrustal rocks, including the migmatitic facies described for the Paleoproterozoic metavolcanosedimentary Sertânia Complex (Santos et al., 2004). This seems to represent a potential source for the parental magmas of the Riacho do Navio and Coloete rocks. In addition, $\mathrm{Sm}-\mathrm{Nd}$ data performed in samples of the Riacho do Navio and Coloete Suites, yield $\mathrm{T}_{\mathrm{DM}}$ model ages indicating Siderian to Mesoarchean sources and highly negative $\varepsilon \mathrm{Nd}(\mathrm{t})$, ranging from -6.15 and -15.25 values, thus also suggesting a crustal derivation. Such older $\mathrm{T}_{\mathrm{DM}}$ model ages might have been trigered by a mixing of 
Paleoproterozoic and Archean sources. Archean crust within the Alto Moxotó Terrane has been recently described by Santos et al., (2016). In addition, other possibility is that such higher negative $\varepsilon N d$ values can also reflect an enriched (metassomatized) mantle source (Menzies et al., 1987).

On the other hand, rocks from the Carnoió Suite are characterized by slightly deformed syenogranites and qtz-syenites. They correspond mostly to alkali-calcic with some scattering to calcic-alkalic, with a wide range of $\mathrm{SiO}_{2}$ content, besides ferroan and metaluminous signatures. Trace elements distribution are characterized by high contents of LILE specially Th and moderate HFSE content, with small depletions on $\mathrm{Nb}$ and $\mathrm{Ta}$. The associated REE pattern is characterized by a moderate fractionation of LREE with respect to HREE, combined with a moderate to strong $\mathrm{Eu}$ anomaly, indicating plagioclase accumulation in the source region (Rollinson, 1993). Such data associated with their plots on discriminant diagrams suggest that they correspond to A-type granites. Hence, their origin must be related to a within-plate tectonic setting. Additionally, samples from the Carnoió Suite plot entirely in the A2-type granitic field following Eby (1992) and Whalen et al., (1987), thus indicating a strong crustal origin, which is also supported by their negative $\varepsilon \mathrm{Nd}_{(\mathrm{t})}$ values.

Incongruent melting of calc-alkaline rocks in low-pressure conditions is generally accepted as a problable mechanism of generation of A-type metaluminous granites (Patiño Douce, 1997). Rhyacian calc-alkaline suites are widespread troughout the Alto Moxotó Terrane (Brito Neves et al., 2001; Santos et al., 2015), thus representing a potential source for the Carnoió Suite rocks. The alkalic-calcic character and the wide $\mathrm{SiO}_{2}$ range, may be caused by incomplete mixing of basaltic and granitic magmas (Frost et al., 1999; Frost and Frost, 2011; Cullers et al., 1992). The participation of this mafic member is reinforced by the crhono-correlated tholeiitic garnet amphibolites described in other portions of the terrane (Santos et al., 2015).

The recognition of A-type granites in the inner portions of the Alto Moxotó Terrane coeval with syn-orogenic to collisional granites in its northern border, suggest that it corresponds to an ancient fragment of a major block that underwent peripheral orogenesis during a major event of continental fragmentation. 


\subsubsection{Tectonic implications and regional correlations}

Along the Borborema Province, rock associations of similar ages are not common and the fewer punctual occurrences are described as the result of a regional taphrogenic event (Brito Neves et al., 1995). In the Rio Grande do Norte Sub Province, Statherian rocks are mainly represented by augen gneisses from the Serra do Deserto Suite (ca. $1.7 \mathrm{Ga}$ ), being referred as A-type granites (Sá et al., 2014), whereas metavolcanossedimentary sequences are interpreted as formed in a continental rift setting on the Orós-Jaguaribe Belt of the Ceará Central Sub Province (Parente and Arthud, 1995). In addition, within the Transversal Sub province, Statherian and Calymmian rocks are concentrated in the Rio Capibaribe Terrane, including the ca. 1.7 Ga Gabro-anorthositic Passira Suite (Accioly, 2000) and calymmian granites and granitic orthogneisses, including the ca. 1.54 Ga Taquaritinga intrusion (Sá et al., 2002). In spite of the scarcity of isotopic data, sources from the Rio Capibaribe terrane are considerably younger than those described by us and present different petrographic and geochemical features, as shown by Accioly, (2000). Within the Alto Moxotó Terrane, the only well known occurrence of rocks with similar age, correspond to the Serra da Barra Suite, presenting sharer petrogenetic characteristics with the Carnoió Suite. Both are located in the innermost portion of the Alto Moxotó Terrane, and we interpret them as a result of continental crust break-up. In Central Africa, events of similar age are described, being constrained by anorthositic complexes and several occurrences of annorogenic granites, being also the result of within-plate magmatism (Cox et al., 2002; DeWaele and Mapani, 2002).

These data is in concordance with rock associations that are described in the transition between Late Paleoproterozoic and Early Mesoproterozoic in several cratonic blocks worldwide. Such settings are marked by the development of large Rift zones and opening of oceanic basins as the result of a global break-up events of Columbia/Nuna as well as minor landmasses (Meert, 2002; Rogers and Santosh, 2002). Nevertheless, we do not have any evidence of metasedimentary and metavolcanic rocks of ca. 1.6 Ga subordinated to raise in a first instance, at least the establishment of a continental Rift, thereby. A possibility is that this landmass might be submitted by crustal thinning induced in part by a mantle plume, as suggested by Condie (2000). 
In general, the Early Paleoproterozoic period $(2.1$ to $1.8 \mathrm{Ga})$ is characterized by the development of several orogenic belts and suture zones, which are the result of the convergence between older blocks, including Archean fragments. For instance, the Trans-Hudson orogen in the Canadian Shield is interpreted as the result of the collision between the Superior Craton to minor crustal segments, such as the Reindeer Zone and the Churchill Province at ca. 1.8 Ga (Corrigan et al., 2009 and references therein). Similar accretion patterns occurred at 1.9-1.8 Ga on the North China (Zhao et al., 2005; Trap et al., 2012) and 2.1-1.8 Slave cratons (Card et al., 2014 and references therein), resulting in the development of the Trans-North-China and Taltson orogens respectively. However, Statherian-Calymmian accretionary and collisional orogens are also reported. Such environments are described in margin zones of cratonic blocks, being commonly referred as peripheral orogens (Condie, 2002). For instance, the 1.8-1$7 \mathrm{Ga}$ Yavapai, 1.7-1.6 Ga Mazatzal and 1.6 Ga Labradorian belts are products of systematic accretion coeval to major break-up events (Zhao et al., 2004 and references therein). Indeed, Rhyacian to Orosirian sequences interpreted as the result of subduction-related magmatism are widespread within the Alto Moxotó Terrane. These associations are interpreted as a result of convergence episodes that culminated in the crustal growth of this domain, which is also constrained by high-grade metamorphic associations (Santos et al., 2015a, Neves et al., 2015b). The unique occurrence of arcrelated to syn-collision 1.6 Ga Riacho do Navio Suite and Coloete orthogneisses on the northern margin of the Alto Moxotó Terrane suggest that this crustal block was subjected to convergent processes during the late Paleoproterozoic period, being coeval to within-plate settings on its inner portions.

The best known example of peripheral orogen in the South American Platform is the 1.8-1.5 Ga Rio Negro-Juruena province, located in the southwestern portion of the Amazonian Craton (Tassinari et al., 1996). In spite of the wide span of lithotypes described along this orogen, including the ca. $1.7 \mathrm{Ga}$ mafic to felsic metaplutonic and metasedimentary rocks of the Jamari Complex (Scandolara et al., 2013) and the granitic and gneissic rocks of the ca. 1.5 Ga Cachoeirinha magmatic arc (Ruiz et al., 2004), that, were originated in a totally different context, the discovery of $1.6 \mathrm{Ga}$ convergent setting at the margin of the Alto Moxotó Terrane reveals that at least this domain can represent a missing puzzle of Paleoproterozoic cratonic blocks as previously suggested by Santos et al., (2015a), or even Supercontinents such as Columbia/Nuna (Murphy and Nance, 
2003; 2013; Roger and Santos, 2004; Condie, 2011; Evans and Mitchell, 2011; Mitchell et al., 2012, among others).

Lastly, we understand that a deep geochronological and geochemical investigation is necessary to better constrain the significance of Paleo-Mesoproterozoic events on the province, especially on the understanding of the nature of crust processes (eg. Hawkesworth et al., 2010; Parman, 2015). Nevertheless, the suggestion of this new convergent Late Paleoproterozoic scenario of the Alto Moxotó Terrane, strongly suggest that it might represent an exotic block within the Neoproterozoic Borborema Province.

\subsection{Conclusions}

In this paper we present new geochemical and geochronogical constraints on the nature of three metaplutonic units of the Paleoproterozoic Alto Moxotó Terrane. Such rocks are assigned to has intruded in the continental crust at ca. 1.6 Ga. The Carnoió Suite, occurs in the central portion of the terrane, presenting unequivocal affinities with A-type granites, recording an event of continental break-up, which has already been described in punctual regions of the province.

On the other hand, the Riacho do Navio Suite and Coloete orthogneiss has petrographic and geochemical signatures compatible to precursor peraluminous magmas, emplaced during a convergent tectonic setting, including arc-related and syncollisional members. Such event, has not yet been described within the province and is not common in the South American Platform as well. However, similar associations are described as the result of peripheral orogenesis of several Paleoproterozoic cratonic blocks worldwide. Such orogens are mostly developed coeval to major events of continental fragmentation, including break-up of supercontinents.

Once we need more data to detail the nature of events recorded in the PaleoMesoproterozoic transition, the occurrence of this unique magmatism in the northern border of the Alto Moxotó Terrane, indicate that it must have collided to an unknown continental margin, thus, suggesting that it must represent a quasi-rigid exotic block, within the Neoproterozoic Borborema Province. 


\subsection{Acknowledgements}

This paper is the outcome of the first author $\mathrm{PhD}$ thesis at Universidade de Brasília, Brazil. Authors are thankful to Universidade de Brasília geochronology lab. 


\begin{tabular}{|c|c|c|c|c|c|c|c|c|c|c|c|c|c|c|c|}
\hline & $\begin{array}{c}\text { Isotopic } \\
\text { ratios }\end{array}$ & & & & & & Ages & & & & & & & & \\
\hline $\begin{array}{l}\text { Grain } \\
\text { spot }\end{array}$ & ${ }^{207} \mathrm{~Pb} /{ }^{206} \mathrm{~Pb}$ & $\pm(1 \sigma)$ & ${ }^{207} \mathrm{~Pb} /{ }^{235} \mathrm{U}$ & $\begin{array}{l} \pm \\
(1 \sigma)\end{array}$ & ${ }^{206} \mathrm{~Pb} /{ }^{238} \mathrm{U}$ & $\begin{array}{l} \pm \\
(1 \sigma)\end{array}$ & ${ }^{207} \mathrm{~Pb} /{ }^{206} \mathrm{~Pb}$ & $\pm(1 \sigma)$ & ${ }^{207} \mathrm{~Pb} /{ }^{235} \mathrm{U}$ & $\begin{array}{l} \pm \\
(1 \sigma)\end{array}$ & ${ }^{206} \mathrm{~Pb} /{ }^{238} \mathrm{U}$ & $\begin{array}{l} \pm \\
(1 \sigma)\end{array}$ & Rho & $\mathrm{Th} / \mathrm{U}$ & Conc. $(\%)$ \\
\hline 004-Z01 & 0.10 & 0.45 & 4.14 & 1.81 & 0.29 & 1.53 & 1630.09 & 0.96 & 1661.73 & 14.77 & 1644.97 & 22.19 & 0.84 & 1.03 & 98.99 \\
\hline 006-Z03 & 0.10 & 0.36 & 2.16 & 1.88 & 0.16 & 1.66 & 1540.08 & 0.88 & 1167.41 & 12.93 & 951.48 & 14.66 & 0.89 & 0.40 & 81.50 \\
\hline 008-Z05 & 0.10 & 0.44 & 3.61 & 3.28 & 0.26 & 2.36 & 1566.57 & 2.28 & 1551.60 & 26.05 & 1501.94 & 31.58 & 0.72 & 0.73 & 96.80 \\
\hline 026-Z018 & 0.10 & 0.52 & 2.97 & 2.55 & 0.22 & 1.90 & 1508.93 & 1.69 & 1400.79 & 19.35 & 1296.91 & 22.36 & 0.74 & 0.47 & 92.58 \\
\hline 028-Z20 & 0.09 & 0.64 & 1.28 & 1.93 & 0.10 & 1.59 & 1459.54 & 1.11 & 837.64 & 10.97 & 606.25 & 9.17 & 0.85 & 0.19 & 72.38 \\
\hline 034-Z24 & 0.20 & 0.59 & 14.68 & 2.37 & 0.54 & 2.02 & 2767.67 & 1.23 & 2794.49 & 22.50 & 2767.00 & 45.50 & 0.85 & 0.18 & 99.02 \\
\hline $035-Z 25$ & 0.18 & 0.46 & 11.11 & 1.70 & 0.46 & 1.31 & 2578.07 & 1.09 & 2532.52 & 15.86 & 2417.94 & 26.42 & 0.76 & 0.39 & 95.48 \\
\hline 037-Z27 & 0.09 & 0.44 & 1.71 & 1.77 & 0.13 & 1.32 & 1420.92 & 1.18 & 1013.00 & 11.29 & 812.90 & 10.06 & 0.76 & 0.33 & 80.25 \\
\hline 038-Z29 & 0.11 & 0.61 & 1.99 & 1.77 & 0.14 & 1.21 & 1666.92 & 1.29 & 1112.38 & 11.86 & 828.34 & 9.38 & 0.70 & 0.40 & 74.47 \\
\hline
\end{tabular}

Table 5.1 - Summary of LA-ICP-MS data of zircons from sample FL-122 (Riacho do Navio Suite). 


\section{Isotopic}

\section{ratios}

Grain

spot

z02

z03

z06

z11

z13

z14

z15

z16

z17

z18

z19

z23

z24

z08

z09

z10

z20

z12

z 21

$\mathrm{z} 22$

z25
${ }^{207} \mathrm{~Pb} /{ }^{206} \mathrm{~Pb}$

0.10

0.10

0.10

0.10

0.10

0.10

0.10

0.10

0.10

0.10

0.10

0.10

0.10

0.10

0.10

0.10

0.10

0.11

0.12

0.11

0.11 $\pm$

$(1 \sigma)$

$\begin{array}{ll}1.17 & 0.25\end{array}$

$\begin{array}{ll}1.85 & 0.26\end{array}$

$\begin{array}{ll}2.29 & 0.27\end{array}$

$\begin{array}{ll}1.85 & 0.27\end{array}$

$\begin{array}{ll}1.73 & 0.27\end{array}$

$\begin{array}{ll}1.28 & 0.26\end{array}$

$\begin{array}{ll}1.97 & 0.24\end{array}$

$\begin{array}{ll}1.07 & 0.29\end{array}$

$\begin{array}{ll}1.51 & 0.29\end{array}$

$2.26 \quad 0.27$

$\begin{array}{ll}1.82 & 0.28\end{array}$

$\begin{array}{ll}1.30 & 0.28\end{array}$

$1.34 \quad 0.30$

$\begin{array}{ll}1.24 & 0.27\end{array}$

$\begin{array}{ll}1.46 & 0.25\end{array}$

$\begin{array}{ll}1.17 & 0.28\end{array}$

$\begin{array}{ll}1.70 & 0.27\end{array}$

$\begin{array}{ll}2.79 & 0.25\end{array}$

$\begin{array}{ll}1.37 & 0.20\end{array}$

$\begin{array}{ll}1.29 & 0.28\end{array}$

$2.92 \quad 0.21$
Ages

$\pm$

$(1 \sigma)$

${ }^{207} \mathrm{~Pb} /{ }^{206} \mathrm{~Pb} \quad \pm(1 \sigma)$

${ }^{207} \mathrm{~Pb} /{ }^{235} \mathrm{U}$

$1.00 \quad 1581.42$

28.56

1493.79

1553.04

1568.22

1558.59

1591.86

51.77

$1.61 \quad 1614.46$

$1.51 \quad 1602.02$

$1.00 \quad 1603.74$

$1.54 \quad 1593.76$

$0.84 \quad 1670.76$

$1.37 \quad 1643.05$

$1.77 \quad 1587.99$

$\begin{array}{ll}1.52 & 1629.88\end{array}$

$\begin{array}{ll}1.01 & 1618.07\end{array}$

$1.15 \quad 1664.94$

$\begin{array}{ll}1.05 & 1654.91\end{array}$

$1.26 \quad 1662.80$

$\begin{array}{ll}0.89 & 1690.78\end{array}$

$1.45 \quad 1693.99$

$1.91 \quad 1871.55$

$1.10 \quad 1881.56$

$1.07 \quad 1750.53$

$2.44 \quad 1854.12$ $\pm$

$9.14 \quad 1432.81$

$14.59 \quad 1513.56$

$18.13 \quad 1550.71$

$14.62 \quad 1517.70$

$13.79 \quad 1560.57$

$10.07 \quad 1466.03$

$15.28 \quad 1410.32$

$8.72 \quad 1641.08$

$12.34 \quad 1645.43$

$17.80 \quad 1530.14$

$14.66 \quad 1611.66$

$10.44 \quad 1608.74$

$11.00 \quad 1691.21$

$10.00 \quad 1548.01$

$11.54 \quad 1432.08$

$9.51 \quad 1589.44$

$13.73 \quad 1561.57$

$22.60 \quad 1434.03$

$10.55 \quad 1157.24$

$10.54 \quad 1572.05$

$22.65 \quad 1210.55$ $\pm$

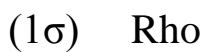
$\begin{array}{lll}12.82 & 0.71 & 0.37\end{array}$ $\begin{array}{lll}20.76 & 0.64 & 0.21\end{array}$ $\begin{array}{llll}22.63 & 0.50 & 0.55\end{array}$ $\begin{array}{lll}21.73 & 0.84 & 0.31\end{array}$ $\begin{array}{lll}0.72 & 0.54 & 97.41\end{array}$ $\begin{array}{lllll}13.07 & 0.74 & 0.29 & 91.41\end{array}$ $\begin{array}{lllll}19.49 & 0.60 & 0.60 & 88.49\end{array}$ $\begin{array}{lllll}12.16 & 0.67 & 0.34 & 98.22\end{array}$ $\begin{array}{llll}19.89 & 0.77 & 0.39 & 100.14\end{array}$ $\begin{array}{lllll}24.09 & 0.77 & 0.47 & 96.36\end{array}$ $\begin{array}{lllll}21.71 & 0.67 & 0.44 & 98.88\end{array}$ $\begin{array}{lllll}14.36 & 0.63 & 0.24 & 99.42\end{array}$ $\begin{array}{lllll}17.17 & 0.71 & 0.46 & 101.58\end{array}$ $\begin{array}{lllll}14.51 & 0.69 & 0.33 & 93.54\end{array}$ $\begin{array}{llll}16.24 & 0.70 & 0.19 & 86.12\end{array}$ $\begin{array}{llll}12.54 & 0.60 & 0.35 & 94.01\end{array}$ $\begin{array}{lllll}20.05 & 0.69 & 0.47 & 92.18\end{array}$ $\begin{array}{lllll}24.53 & 0.46 & 0.22 & 76.62\end{array}$ $\begin{array}{llll}11.63 & 0.64 & 0.26 & 61.50\end{array}$ $\begin{array}{llll}14.99 & 0.72 & 0.29 & 89.80\end{array}$ $\begin{array}{llll}26.88 & 0.82 & 0.20 & 65.29\end{array}$

Table 5.2 - Summary of LA-ICP-MS data of zircons from sample FL-122 (Coloete orthogneiss). 


\begin{tabular}{|c|c|c|c|c|c|c|c|c|c|c|c|c|c|c|c|}
\hline & $\begin{array}{l}\text { Isotopic } \\
\text { ratios }\end{array}$ & & & & & & Ages & & & & & & & & \\
\hline Grain spot & ${ }^{207} \mathrm{~Pb} /{ }^{206} \mathrm{~Pb}$ & $\pm(1 \sigma)$ & ${ }^{207} \mathrm{~Pb} /{ }^{235} \mathrm{U}$ & $\pm(1 \sigma)$ & ${ }^{206} \mathrm{~Pb} /{ }^{238} \mathrm{U}$ & $\pm(1 \sigma)$ & ${ }^{207} \mathrm{~Pb} /{ }^{206} \mathrm{~Pb}$ & $\pm(1 \sigma)$ & ${ }^{207} \mathrm{~Pb} /{ }^{235} \mathrm{U}$ & $\pm(1 \sigma)$ & ${ }^{206} \mathrm{~Pb} /{ }^{238} \mathrm{U}$ & $\pm(1 \sigma)$ & Rho & $\mathrm{Th} / \mathrm{U}$ & Conc. $(\%)$ \\
\hline Z01 & 0.06 & 1.20 & 0.77 & 1.56 & 0.09 & 1.00 & 584 & 26 & 583 & 7 & 582 & 6 & 0.59 & 0.43 & 99.95 \\
\hline Z03 & 0.06 & 1.50 & 0.78 & 1.72 & 0.09 & 0.84 & 605 & 32 & 589 & 8 & 585 & 6 & 0.58 & 0.62 & 99.33 \\
\hline Z07 & 0.09 & 1.84 & 2.96 & 2.44 & 0.22 & 1.61 & 1565 & 34 & 1400 & 18 & 1294 & 19 & 0.83 & 0.19 & 92.43 \\
\hline $\mathrm{Z} 12$ & 0.09 & 1.22 & 2.89 & 2.26 & 0.22 & 1.91 & 1537 & 23 & 1381 & 17 & 1282 & 22 & 0.85 & 0.26 & 92.86 \\
\hline Z21 & 0.10 & 1.96 & 2.90 & 2.99 & 0.22 & 2.26 & 1536 & 36 & 1382 & 22 & 1285 & 26 & 0.90 & 0.24 & 92.96 \\
\hline Z17 & 0.10 & 1.35 & 3.07 & 1.84 & 0.23 & 1.25 & 1543 & 25 & 1425 & 14 & 1347 & 15 & 0.83 & 0.24 & 94.55 \\
\hline Z09 & 0.10 & 1.12 & 3.30 & 2.00 & 0.24 & 1.65 & 1573 & 21 & 1482 & 15 & 1419 & 21 & 0.83 & 0.35 & 95.76 \\
\hline Z16 & 0.10 & 0.70 & 3.40 & 1.18 & 0.25 & 0.96 & 1593 & 13 & 1504 & 9 & 1442 & 12 & 0.80 & 0.21 & 95.88 \\
\hline Z19 & 0.10 & 0.92 & 3.44 & 1.54 & 0.25 & 1.25 & 1594 & 17 & 1515 & 12 & 1458 & 16 & 0.79 & 0.24 & 96.28 \\
\hline $\mathrm{Z} 20$ & 0.09 & 0.79 & 3.49 & 1.94 & 0.26 & 1.77 & 1598 & 15 & 1526 & 15 & 1475 & 23 & 0.92 & 0.37 & 96.66 \\
\hline $\mathrm{z} 13-2$ & 0.09 & 1.15 & 3.57 & 1.71 & 0.26 & 1.26 & 1609 & 21 & 1543 & 13 & 1495 & 17 & 0.87 & 0.21 & 96.90 \\
\hline Z04 & 0.10 & 0.77 & 3.52 & 1.30 & 0.26 & 1.04 & 1595 & 14 & 1532 & 10 & 1487 & 14 & 0.81 & 0.22 & 97.04 \\
\hline Z24 & 0.10 & 0.76 & 3.49 & 1.16 & 0.28 & 0.87 & 1589 & 14 & 1527 & 9 & 1482 & 12 & 0.73 & 0.28 & 97.10 \\
\hline Z23 & 0.10 & 0.84 & 3.62 & 1.16 & 0.27 & 0.81 & 1607 & 16 & 1555 & 9 & 1517 & 11 & 0.66 & 0.21 & 97.56 \\
\hline Z15 & 0.09 & 0.65 & 3.76 & 1.12 & 0.27 & 0.92 & 1624 & 12 & 1584 & 9 & 1555 & 13 & 0.82 & 0.27 & 98.14 \\
\hline Z05 & 0.10 & 0.77 & 3.91 & 1.20 & 0.28 & 0.92 & 1643 & 14 & 1617 & 10 & 1597 & 13 & 0.77 & 0.27 & 98.77 \\
\hline Z14 & 0.10 & 0.67 & 3.87 & 1.10 & 0.28 & 0.87 & 1632 & 12 & 1608 & 9 & 1590 & 12 & 0.79 & 0.30 & 98.90 \\
\hline Z11 & 0.09 & 1.21 & 3.81 & 1.61 & 0.28 & 1.06 & 1615 & 22 & 1595 & 13 & 1580 & 15 & 0.81 & 0.20 & 99.07 \\
\hline Z22 & 0.10 & 0.91 & 3.89 & 2.11 & 0.28 & 1.90 & 1630 & 17 & 1612 & 17 & 1597 & 27 & 0.91 & 0.38 & 99.11 \\
\hline Z18 & 0.10 & 0.81 & 3.94 & 1.62 & 0.28 & 1.41 & 1635 & 15 & 1622 & 13 & 1512 & 20 & 0.87 & 0.34 & 99.39 \\
\hline Z13-1 & 0.09 & 0.70 & 3.86 & 1.34 & 0.28 & 1.14 & 1614 & 13 & 1607 & 11 & 1691 & 16 & 0.86 & 0.18 & 99.64 \\
\hline Z08 & 0.10 & 1.09 & 4.04 & 2.51 & 0.29 & 2.26 & 1646 & 20 & 1642 & 20 & 1639 & 33 & 0.90 & 0.49 & 99.81 \\
\hline Z10 & 0.10 & 0.74 & 4.11 & 1.22 & 0.29 & 0.96 & 1646 & 14 & 1656 & 10 & 1665 & 14 & 0.79 & 0.22 & 100.52 \\
\hline
\end{tabular}

Table 5.3 - Summary of LA-ICP-MS data of zircons from sample RS-425 (Carnoió Suite). 


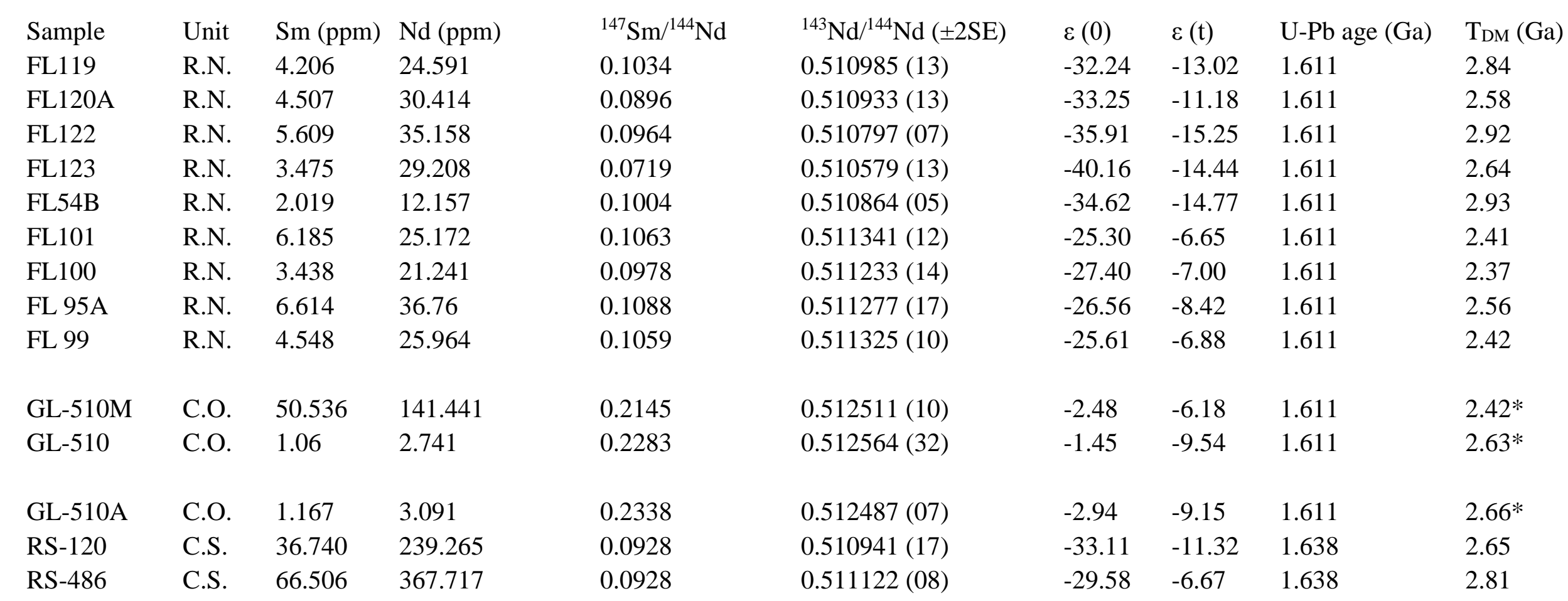

Table 5.4 - Summary of Nd isotope data for the sutided metaplutonites. R.N. = Riacho do Navio Suite; C.O. = Coloete orthogneiss; C.S. =

Carnoió suite. 
Sample RN 1 RN 2 RN 3 RN 4 RN 5 RN 6 RN 07 FL99 FL100 FL101 FL102 FL103 FL104 Major elements (wt.\%)

\begin{tabular}{|c|c|c|c|c|c|c|c|c|c|c|c|c|c|}
\hline $\mathrm{Al}_{2} \mathrm{O}_{3}$ & 16.75 & 16.85 & 14.6 & 14.9 & 14.55 & 13.4 & 14.45 & 12.8 & 12.85 & 11.1 & 11.25 & 13.45 & 13.2 \\
\hline $\mathrm{CaO}$ & 2.12 & 4.04 & 1.9 & 1.84 & 1.98 & 1.34 & 1.15 & 0.84 & 0.84 & 0.74 & 0.75 & 1.34 & 1.31 \\
\hline $\mathrm{Fe}_{2} \mathrm{O}_{3}$ & 4.76 & 4.59 & 5 & 4.37 & 4.16 & 2.83 & 2.57 & 1.08 & 1.06 & 0.92 & 0.97 & 2.01 & 1.97 \\
\hline $\mathrm{K}_{2} \mathrm{O}$ & .83 & 2.03 & 4.74 & 5.2 & 4.69 & 4.22 & 5.29 & 4.79 & 4.85 & 3.77 & 5 & 4.27 & 4.15 \\
\hline $\mathrm{MgO}$ & 1.02 & 1.08 & 1.22 & 0.96 & 0.93 & 0.48 & 0.65 & 0.14 & 0.14 & 0.13 & 0.12 & 0.4 & 0.4 \\
\hline $\mathrm{MnO}$ & 0.06 & 0.05 & 0.05 & 0.04 & 0.04 & 0.04 & 0.03 & 0.02 & 0.02 & 0.01 & 0.02 & 0.03 & 0.03 \\
\hline $\mathrm{Na}_{2} \mathrm{O}$ & 3.75 & 4.41 & 3.1 & 3.25 & 3.28 & 3.28 & 3.25 & 3 & 3 & 2.89 & 2.92 & 3.37 & 3.31 \\
\hline $\mathrm{P}_{2} \mathrm{O}_{5}$ & 0.28 & 0.28 & 0.24 & 0.21 & 0.23 & 0.12 & 0.13 & 0.05 & 0.04 & 0.05 & 0.05 & 0.09 & 0.08 \\
\hline $\mathrm{SiO}_{2}$ & 75.1 & 73.1 & 68.2 & 67.5 & 67.5 & 75 & 73.4 & 78.2 & 78.1 & 79.3 & 0 & 74.4 & 75.9 \\
\hline $\mathrm{TiO}_{2}$ & 0.75 & 0.8 & 0.74 & 0.76 & 0.75 & 0.3 & 0.31 & 0.13 & 0.13 & 0.1 & 0.11 & 0.27 & 0.26 \\
\hline LOI & 0.67 & 0.71 & 0.41 & 0.27 & 0.27 & 0.28 & 0.36 & 0.62 & 0.57 & 0.40 & 0.42 & 0.51 & 0.55 \\
\hline Total & 102.0 & 102.0 & 100.4 & 99.50 & 99.57 & 101.4 & 101.7 & 101.7 & 101.6 & 99.4 & 99.0 & 101.2 & 101.2 \\
\hline \multicolumn{14}{|c|}{ Trace elements (ppm) } \\
\hline $\mathrm{Ba}$ & 1400 & 915 & 1195 & 1450 & 1330 & 513 & 781 & 349 & 340 & 286 & 286 & 520 & 508 \\
\hline $\mathrm{Ce}$ & 417 & 468 & 346 & 427 & 424 & 173.5 & 179.5 & 79.1 & 75.2 & 472 & 70.9 & 151 & 150.5 \\
\hline $\mathrm{Cr}$ & 60 & 80 & 70 & 60 & 70 & 100 & 60 & 10 & 10 & 10 & 20 & 10 & 10 \\
\hline Cs & 1.62 & 1.44 & 1.7 & 1.61 & 1.56 & 1.21 & 1.21 & 0.94 & 0.93 & 0.7 & 0.79 & 1.03 & 0.97 \\
\hline Dy & 5.9 & 4.76 & 4.07 & 4.89 & 5.19 & 3.91 & 3.22 & 2.91 & 2.84 & 14 & 2.96 & 3.84 & 3.45 \\
\hline $\mathrm{Er}$ & 2.02 & 1.86 & 1.75 & 1.49 & 2.03 & 1.57 & 1.35 & 1.67 & 1.54 & 4.71 & 1.63 & 1.61 & 1.44 \\
\hline $\mathrm{Eu}$ & 2.14 & 1.6 & 1.48 & 2.19 & 2.25 & 0.87 & 0.9 & 0.52 & 0.54 & 1.51 & 0.53 & 0.91 & 0.81 \\
\hline $\mathrm{Ga}$ & 26.1 & 27.8 & 26.7 & 27.4 & 27.6 & 21.3 & 21.1 & 19.4 & 19.8 & 19.9 & 18.3 & 22.1 & 22.3 \\
\hline $\mathrm{Gd}$ & 10.1 & 7.23 & 7.22 & 9.61 & 9.77 & 5.19 & 4.23 & 3.4 & 3.17 & 21 & 3.12 & 4.66 & 4.4 \\
\hline $\mathrm{Hf}$ & 18.3 & 16.6 & 13.6 & 12.9 & 18.4 & 6.2 & 5.9 & 4.4 & 3.3 & 4.7 & 4.8 & 7.6 & 7 \\
\hline Ho & 0.9 & 0.81 & 0.69 & 0.76 & 0.81 & 0.64 & 0.55 & 0.59 & 0.54 & 2.03 & 0.56 & 0.6 & 0.57 \\
\hline
\end{tabular}




$\begin{array}{llllllllllllll}\mathrm{La} & 258 & 150.5 & 173.5 & 252 & 279 & 93.5 & 100.5 & 40.5 & 39.1 & 266 & 40 & 86.6 & 86.6 \\ \mathrm{Lu} & 0.19 & 0.15 & 0.16 & 0.13 & 0.17 & 0.14 & 0.16 & 0.21 & 0.18 & 0.29 & 0.21 & 0.16 & 0.14 \\ \mathrm{Nb} & 29.4 & 37.1 & 26.4 & 26.7 & 27.8 & 15 & 14 & 6.7 & 6.7 & 5.8 & 5.7 & 13.3 & 13.6 \\ \mathrm{Nd} & 132 & 78.5 & 90.4 & 129 & 145.5 & 48.6 & 49.1 & 23.2 & 21.8 & 159 & 22.6 & 46.4 & 44.7 \\ \mathrm{Pr} & 43 & 25.3 & 29.5 & 42.7 & 47.3 & 15.8 & 15.85 & 7.22 & 6.84 & 46.3 & 6.74 & 14.15 & 13.75 \\ \mathrm{Rb} & 221 & 128 & 218 & 223 & 218 & 206 & 236 & 186 & 183 & 157 & 155.5 & 194.5 & 202 \\ \mathrm{Sm} & 15.75 & 11.05 & 11.9 & 17.15 & 18.55 & 7.69 & 6.94 & 4.18 & 4 & 28.8 & 3.92 & 6.81 & 7 \\ \mathrm{Sn} & 3 & 4 & 4 & 4 & 4 & 4 & 3 & 2 & 2 & 1 & 1 & 4 & 3 \\ \mathrm{Sr} & 270 & 255 & 229 & 264 & 265 & 142.5 & 160 & 85.6 & 84 & 74.7 & 74.4 & 138.5 & 140 \\ \mathrm{Ta} & 2.6 & 2.4 & 2.7 & 2.5 & 2.5 & 1.1 & 0.9 & 0.6 & 0.6 & 0.6 & 0.6 & 0.9 & 0.9 \\ \mathrm{~Tb} & 1.24 & 0.92 & 0.85 & 1.03 & 1.24 & 0.69 & 0.54 & 0.55 & 0.46 & 2.71 & 0.49 & 0.69 & 0.64 \\ \mathrm{Th} & 85.9 & 84.8 & 73.4 & 72.6 & 77.9 & 66.3 & 50.9 & 30.8 & 31.5 & 227 & 29.4 & 64.7 & 60.8 \\ \mathrm{Tm} & 0.33 & 0.29 & 0.21 & 0.22 & 0.25 & 0.2 & 0.2 & 0.27 & 0.23 & 0.52 & 0.22 & 0.19 & 0.19 \\ \mathrm{U} & 2.02 & 1.52 & 1.67 & 1.47 & 1.55 & 3.57 & 4.13 & 8.16 & 8.19 & 15.8 & 6.55 & 3.82 & 3.62 \\ \mathrm{~V} & 49 & 54 & 47 & 44 & 43 & 20 & 22 & 17 & 17 & 14 & 21 & 14 & 15 \\ \mathrm{~W} & 5 & 4 & 3 & 3 & 4 & 6 & 3 & 510 & 547 & 565 & 642 & 422 & 430 \\ \mathrm{Y} & 26.1 & 21.7 & 19.7 & 20.3 & 22.1 & 17 & 16.7 & 17.8 & 16.2 & 60.6 & 17.2 & 17.8 & 17.4 \\ \mathrm{Yb} & 1.71 & 1.06 & 1.29 & 1.2 & 1.4 & 0.96 & 1.26 & 1.53 & 1.3 & 2.59 & 1.5 & 1.26 & 1.03 \\ \mathrm{Zr} & 763 & 703 & 600 & 584 & 741 & 242 & 242 & 143 & 98 & 138 & 138 & 243 & 230\end{array}$

Table 5.5 - Major (wt. \%) and trace element (ppm) concentrations of the Riacho do Navio Suite, Alto Moxotó Terrane, NE Brazil. 


\begin{tabular}{|c|c|c|c|c|c|c|c|c|}
\hline Sample & GL-144 & GL-490 & GL-502 & GL-511 & GL-515 & GL-03A* & GL-142* & GL-146 \\
\hline \multicolumn{9}{|c|}{ Major elements (wt.\%) } \\
\hline $\mathrm{Al}_{2} \mathrm{O}_{3}$ & 15.10 & 15.72 & 15.47 & 15.96 & 15.37 & 15.40 & 15.03 & 14.78 \\
\hline $\mathrm{CaO}$ & 1.24 & 1.32 & 1.10 & 2.66 & 2.74 & 1.55 & 1.48 & 1.76 \\
\hline $\mathrm{Fe}_{2} \mathrm{O}_{3}$ & 1.66 & 1.25 & 1.38 & 1.61 & 2.73 & 2.64 & 2.39 & 2.87 \\
\hline $\mathrm{K}_{2} \mathrm{O}$ & 5.17 & 5.34 & 4.81 & 3.47 & 2.69 & 4.65 & 5.24 & 5.13 \\
\hline $\mathrm{MgO}$ & 0.37 & 0.36 & 0.44 & 0.39 & 0.72 & 0.64 & 0.62 & 0.55 \\
\hline $\mathrm{MnO}$ & 0.02 & 0.01 & 0.02 & 0.02 & 0.03 & 0.03 & 0.03 & 0.04 \\
\hline $\mathrm{Na}_{2} \mathrm{O}$ & 3.87 & 4.17 & 4.19 & 4.29 & 4.36 & 4.71 & 4.18 & 3.21 \\
\hline $\mathrm{P}_{2} \mathrm{O}_{5}$ & 0.08 & 0.09 & 0.12 & 0.06 & 0.09 & 0.11 & 0.12 & 0.08 \\
\hline $\mathrm{SiO}_{2}$ & 71.55 & 70.77 & 71.91 & 70.61 & 70.10 & 73.08 & 72.17 & 69.43 \\
\hline $\mathrm{TiO}_{2}$ & 0.29 & 0.27 & 0.22 & 0.23 & 0.39 & 0.32 & 0.33 & 0.23 \\
\hline LOI & 0.50 & 0.40 & 0.20 & 0.50 & 0.70 & 0.10 & 0.16 & 0.18 \\
\hline Total & 99.80 & 99.71 & 99.85 & 99.77 & 99.90 & 101.24 & 101.75 & 98.26 \\
\hline \multicolumn{9}{|c|}{ Trace elements (ppm) } \\
\hline $\mathrm{Ba}$ & 1439 & 1461 & 626 & 1120 & 460 & 1737 & 1316 & 1732 \\
\hline $\mathrm{Ce}$ & 86.2 & 54.1 & 57.1 & 30.2 & 34.1 & 59.1 & 50.8 & 99.1 \\
\hline $\mathrm{Cr}$ & n.d. & n.d. & n.d. & n.d. & n.d. & n.d. & n.d. & n.d. \\
\hline Cs & 5 & 5 & 5.1 & 4.2 & 4.3 & 0.71 & 7.27 & 2.89 \\
\hline Dy & 1.28 & 0.8 & 0.73 & 0.89 & 1.15 & 1.05 & 0.79 & 1.42 \\
\hline $\mathrm{Er}$ & 0.27 & 0.14 & 0.26 & 0.34 & 0.37 & 0.41 & 0.38 & 0.19 \\
\hline $\mathrm{Eu}$ & 1.24 & 0.99 & 0.77 & 0.68 & 0.72 & 0.87 & 0.95 & 1.58 \\
\hline $\mathrm{Ga}$ & 26.1 & 23.5 & 25.8 & 20.3 & 20.2 & 21.8 & 25.3 & 16.7 \\
\hline $\mathrm{Gd}$ & 3.19 & 2.53 & 1.97 & 2.11 & 1.64 & 2.43 & 3.44 & 3.98 \\
\hline Hf & 5.9 & 4.7 & 3.3 & 2.9 & 3.5 & 5 & 5.87 & 4.22 \\
\hline Ho & 0.13 & 0.07 & 0.09 & 0.13 & 0.18 & 0.05 & 0.05 & 0.06 \\
\hline
\end{tabular}




$\begin{array}{lllllllll}\mathrm{La} & 47.3 & 27.1 & 28.4 & 26.4 & 17.9 & 39.1 & 25 & 53 \\ \mathrm{Lu} & 0.05 & 0.02 & 0.04 & 0.03 & 0.03 & 0.05 & 0.05 & 0.05 \\ \mathrm{Nb} & 12.8 & 6.9 & 4.5 & 4.8 & 8.4 & 5.64 & 9.14 & 8.09 \\ \mathrm{Nd} & 33.6 & 23.8 & 22.9 & 19.3 & 12.7 & 21.3 & 21.7 & 38.1 \\ \mathrm{Pr} & 9.64 & 6.17 & 6.59 & 5.33 & 3.78 & 6.12 & 5.82 & 11.09 \\ \mathrm{Rb} & 172.5 & 160.3 & 170.6 & 100.1 & 102.4 & 115.7 & 203.7 & 148 \\ \mathrm{Sm} & 5.4 & 4.11 & 4.23 & 3.17 & 2.25 & 3.2 & 3.7 & 6.9 \\ \mathrm{Sn} & 5 & 4 & 6 & 2 & 2 & 3.4 & 4.3 & 7.6 \\ \mathrm{Sr} & 733.8 & 628 & 232.3 & 447 & 282.5 & 513.8 & 516.6 & 522.1 \\ \mathrm{Ta} & 1.1 & 0.6 & 1 & 0.3 & 0.8 & 0.38 & 0.91 & 0.39 \\ \mathrm{~Tb} & 0.32 & 0.24 & 0.19 & 0.24 & 0.24 & 0.28 & 0.38 & 0.37 \\ \mathrm{Th} & 20.4 & 16.7 & 16.5 & 5.7 & 6 & 8.6 & 13.4 & 20.1 \\ \mathrm{Tm} & 0.05 & 0.03 & 0.05 & 0.04 & 0.05 & 0.05 & 0.05 & 0.08 \\ \mathrm{U} & 4.1 & 4 & 5 & 1.5 & 0.8 & 0.75 & 4.37 & 2.01 \\ \mathrm{~V} & 45 & 21 & 14 & 13 & 35 & \text { n.d. } & \text { n.d. } & \text { n.d. } \\ \mathrm{W} & \text { n.d. } & \text { n.d. } & \text { n.d. } & \text { n.d. } & \text { n.d. } & \text { n.d. } & \text { n.d. } & 3.7 \\ \mathrm{Y} & 4.9 & 2.7 & 3.3 & 4.6 & 5.2 & 5.8 & 3.75 & 4.75 \\ \mathrm{Yb} & 0.35 & 0.14 & 0.24 & 0.21 & 0.25 & 0.6 & 0.4 & 0.1 \\ \mathrm{Zr} & 181.8 & 165.9 & 113.7 & 100.7 & 116.8 & 182 & 171 & 131.1\end{array}$

Table 5.6 - Major (wt. \%) and trace element (ppm) concentrations of the Coloete orthogneisses, Alto Moxotó Terrane, NE Brazil. 
RS- $\quad$ RS- $\quad$ RS- $\quad$ RS- $\quad$ RS- $\quad$ RS- $\quad$ RS- GL- GL- GL- GL- GL$\begin{array}{lllllllllllll}\text { Sample } & 425 & 457 & 460 & 486 & 490 & 120 & 421 & 430 & 420 & 471 & 520 & \text { 018C }\end{array}$ Major elements (wt.\%)

$\begin{array}{lllllllllllll}\mathrm{Al}_{2} \mathrm{O}_{3} & 14.00 & 14.48 & 11.92 & 13.95 & 13.40 & 13.85 & 14.16 & 13.59 & 15.33 & 13.60 & 11.65 & 12.35 \\ \mathrm{CaO} & 2.72 & 2.20 & 0.89 & 2.73 & 2.75 & 1.65 & 2.83 & 1.94 & 2.28 & 2.08 & 1.52 & 1.97 \\ \mathrm{Fe}_{2} \mathrm{O}_{3} & 8.63 & 5.45 & 2.99 & 8.49 & 8.58 & 4.91 & 9.01 & 4.80 & 4.19 & 5.47 & 6.78 & 4.11 \\ \mathrm{~K}_{2} \mathrm{O} & 5.47 & 5.26 & 5.71 & 5.43 & 5.41 & 6.34 & 5.80 & 6.02 & 4.00 & 5.44 & 5.18 & 5.12 \\ \mathrm{MgO} & 0.07 & 0.16 & 0.06 & 0.08 & 0.06 & 0.09 & 0.10 & 0.05 & 0.54 & 0.52 & 0.32 & 0.13 \\ \mathrm{MnO} & 0.15 & 0.07 & 0.04 & 0.14 & 0.14 & 0.09 & 0.15 & 0.08 & 0.06 & 0.07 & 0.09 & 0.03 \\ \mathrm{Na}_{2} \mathrm{O} & 3.09 & 3.17 & 2.48 & 3.20 & 3.07 & 3.09 & 3.10 & 3.08 & 4.02 & 2.86 & 2.51 & 2.26 \\ \mathrm{P}_{2} \mathrm{O}_{5} & 0.07 & 0.10 & \text { n.d. } & 0.09 & 0.08 & 0.04 & 0.11 & 0.06 & 0.11 & 0.15 & 0.13 & 0.06 \\ \mathrm{SiO}_{2} & 64.40 & 67.85 & 74.82 & 63.58 & 65.08 & 68.92 & 63.30 & 68.87 & 68.40 & 68.61 & 70.59 & 72.99 \\ \mathrm{TiO}_{2} & 0.63 & 0.44 & 0.21 & 0.60 & 0.61 & 0.35 & 0.67 & 0.36 & 0.40 & 0.62 & 0.73 & 0.41 \\ \mathrm{LOI} & 0.00 & 0.20 & 0.20 & 0.50 & 1.00 & 0.20 & 0.20 & 0.10 & 0.60 & 0.90 & 0.40 & 0.20 \\ \mathrm{Total} & 99.24 & 99.39 & 99.62 & 99.27 & 99.39 & 99.42 & 99.32 & 99.46 & 99.71 & 99.61 & 99.70 & 99.63 \\ \mathrm{Trace} & \mathrm{elements} & \text { ppm) } & & & & & & & & & & \\ \mathrm{Ba} & 2369 & 3014 & 1723 & 2442 & 1989 & 2719 & 2335 & 2194 & 1357 & 1259 & 1003 & 1286 \\ \mathrm{Ce} & 683.9 & 261.2 & 280.6 & 574.6 & 623.6 & 501 & 560.4 & 534.7 & 139.3 & 340.8 & 317.1 & 257.7 \\ \mathrm{Cr} & \text { n.d. } & \text { n.d. } & \text { n.d. } & \text { n.d. } & \text { n.d. } & \text { n.d. } & \text { n.d. } & \text { n.d. } & \text { n.d. } & \text { n.d. } & \text { n.d. } & \text { n.d. } \\ \mathrm{Cs} & 0.5 & 0.1 & 0.3 & 0.6 & 0.5 & 0.6 & 0.4 & 0.6 & 4.4 & 0.6 & 0.5 & 0.1 \\ \mathrm{Dy} & 26.82 & 11.53 & 10.09 & 28.18 & 23.66 & 19.22 & 22.98 & 27.49 & 13.86 & 18.15 & 15.5 & 19.88 \\ \mathrm{Er} & 13.69 & 5.79 & 5.23 & 14.58 & 11.95 & 8.87 & 12.2 & 13.29 & 7.65 & 10.06 & 7.59 & 11.74 \\ \mathrm{Eu} & 8.13 & 5.5 & 4.24 & 7.08 & 6.44 & 6.91 & 6.38 & 6.18 & 1.73 & 2.93 & 3.04 & 2.98 \\ \mathrm{Ga} & 29.3 & 22.9 & 20.1 & 28.9 & 27.7 & 27.8 & 30.8 & 27.9 & 22.8 & 21.4 & 19.8 & 21.9 \\ \mathrm{Gd} & 38.11 & 15.02 & 12.97 & 34.42 & 29.64 & 26.28 & 27.02 & 34.38 & 14.53 & 18.55 & 19.81 & 21.47 \\ \mathrm{Hf} & 35.9 & 17.9 & 12.7 & 33.3 & 31.9 & 16.9 & 37.1 & 18.8 & 10.4 & 23.2 & 26.7 & 23.2\end{array}$




$\begin{array}{lllllllllllll}\mathrm{Ho} & 4.97 & 2.13 & 1.88 & 5.29 & 4.42 & 3.36 & 4.48 & 5 & 2.71 & 3.52 & 2.8 & 4.12 \\ \mathrm{La} & 365.1 & 132.2 & 150 & 290.7 & 259.9 & 253.9 & 165.5 & 264.2 & 70 & 176.9 & 161.7 & 121.7 \\ \mathrm{Lu} & 2.02 & 0.78 & 0.73 & 2.16 & 1.83 & 1.28 & 1.9 & 1.73 & 0.96 & 1.38 & 0.98 & 1.37 \\ \mathrm{Nb} & 97.8 & 33.1 & 33.2 & 104.8 & 92 & 63.1 & 103.1 & 63.9 & 12.9 & 52.3 & 35.5 & 35 \\ \mathrm{Nd} & 335.4 & 122.3 & 119.8 & 285.1 & 247.6 & 230.1 & 187.4 & 264.5 & 72.7 & 131.1 & 133.8 & 107.6 \\ \mathrm{Pr} & 85.22 & 32.19 & 32.17 & 72.51 & 65.09 & 59.12 & 47.28 & 65.83 & 18.36 & 37.24 & 36.06 & 28.06 \\ \mathrm{Rb} & 118.8 & 87.5 & 107.4 & 116.3 & 115.4 & 132.7 & 122.3 & 132.6 & 97.1 & 173 & 117.3 & 95.4 \\ \mathrm{Sm} & 49.96 & 20.2 & 17.92 & 45.05 & 40.12 & 34.5 & 32.93 & 43.4 & 15.03 & 22.04 & 23.18 & 21.23 \\ \mathrm{Sn} & 3 & \text { n.d. } & 1 & 4 & 3 & 2 & 2 & 2 & 4 & 4 & 3 & 3 \\ \mathrm{Sr} & 142 & 269.5 & 132 & 147.4 & 130.6 & 142.7 & 144.3 & 139.3 & 194.1 & 114.6 & 89.9 & 140.7 \\ \mathrm{Ta} & 3.8 & 1.4 & 1.5 & 4.2 & 3.6 & 2.6 & 4 & 2.7 & 0.8 & 2.7 & 1.6 & 1.4 \\ \mathrm{~Tb} & 5.45 & 2.32 & 1.99 & 5.35 & 4.55 & 3.68 & 4.23 & 5.05 & 2.45 & 3.14 & 2.97 & 3.51 \\ \mathrm{Th} & 33.8 & 8.7 & 22.9 & 39.5 & 25.5 & 25.9 & 27 & 27.6 & 6.3 & 34.9 & 38.4 & 42.7 \\ \mathrm{Tm} & 2.04 & 0.86 & 0.77 & 2.19 & 1.8 & 1.35 & 1.87 & 1.93 & 1.13 & 1.59 & 1.05 & 1.73 \\ \mathrm{U} & 2.6 & 0.8 & 2.5 & 3.5 & 2.6 & 2.1 & 2.5 & 2.6 & 1.5 & 2.2 & 2.3 & 2.5 \\ \mathrm{~V} & \text { n.d. } & \text { n.d. } & \text { n.d. } & \text { n.d. } & \text { n.d. } & \text { n.d. } & \text { n.d. } & \text { n.d. } & \text { n.d. } & \text { n.d. } & \text { n.d. } & \text { n.d. } \\ \mathrm{W} & 0.5 & \text { n.d. } & \text { n.d. } & \text { n.d. } & \text { n.d. } & 1.1 & \text { n.d. } & 1 & \text { n.d. } & 1.4 & 0.5 & \text { n.d. } \\ \mathrm{Y} & 132.9 & 54.6 & 47.7 & 129.9 & 108.9 & 89.6 & 102.4 & 116.8 & 76 & 98.5 & 76 & 107.9 \\ \mathrm{Yb} & 12.76 & 5.12 & 4.98 & 13.8 & 11.55 & 8.02 & 12.31 & 11.69 & 6.44 & 9.5 & 6.43 & 10.16 \\ \mathrm{Zr} & 1433 & 704.3 & 434 & 1305.2 & 1328.1 & 653.1 & 1621.4 & 782.8 & 358.9 & 862.6 & 892.6 & 889.9\end{array}$

Table 5.7 - Major (wt. \%) and trace element (ppm) concentrations of the Carnoió Suite, Alto Moxotó Terrane, NE Brazil. 


\subsection{References}

Accioly, A.C.A., 2000. Geologia, geoquímica e significado tectônico do Complexo Metanortosítico de Passira, Província Borborema, Nordeste Brasileiro (PhD thesis). Universidade de São Paulo, São Paulo, p. 168.

Åhäll, K.-I. and Connely, J., 1998. Intermittent 1.53-1.13 Ga magmatism in western Baltica: age constrains and correlation within a postulated supercontinent. Precambrian Research, 92: 1-20.

Almeida, F.F.M., Hasui, Y., Brito Neves, B.B., Fuck, R.A., 1981. Brazilian structural provinces: an introduction. Earth Science Reviews 18, 1-29.

Araujo, C.E.G., Cordani, G.U., Weinberg, R., Basei, M.A.S., Armostrong, R., Sato, K. 2014a. Tracing Neoproterozoic subduction in the Borborema Province (NE- Brazil): clues from $\mathrm{U}-\mathrm{Pb}$ geochronology and $\mathrm{Sr}-\mathrm{Nd}-\mathrm{Hf}-\mathrm{O}$ isotopes on granitoids and migmatites. Lithos 202-203, 167-189.

Araujo, C.E.G., Rubatto, D., Hermann, J., Cordani, G.U., Caby, R., Basei, M.A.S. 2014b. Ediacaran 2,500 km-long synchronous deep continental subduction in the West Gondwana Orogen. Nature Communications 1, 1-8.

Arthaud, M.H., Nogueira Neto, J.A., Wernick, E. 2003. Evidence for Neoproterozoic continental arc magmatism in the Santa Quiteria Batholith of Ceará State, NW Borborema Province, NE Brazil: implications for the assembly of West Gondwana. Gondwana Research 6, 265-273.

Ayres, M., Harris, N., 1997. REE fractionation and Nd-isotope disequilibrium during crustal anatexis: constraints from himalayan leucogranites. Chemical Geology 139, 249269.

Barbarin, B., 1996. Genesis of the two main types of peraluminous granitoids. Geology 24, 295-298.

Barbarin, B., 1999. A review of the relationships between granidoid types, their origins and their geodynamic environments. Lithos 46, 605-626.

Bleeker, W., 2003. The late Archean record: a puzzle in ca. 35 pieces. Lithos, 71, 99134. 
Brito Neves, B.B., 1975. Regionalização Geotectônica Do Précambriano Nordestino (Tese de Doutorado). Universidade de São Paulo, São Paulo, p. 198.

Brito Neves, B.B., Van Schmus, W.R., Santos, E.J., Campos Neto, M.C., Kozuch, M. 1995. O Evento Cariris Velhos na Província Borborema: integração de dados, implicações e perspectivas. Revista Brasileira de Geociências 25, 279-296.

Brito Neves, B.B., Santos, E.J., Schmus, W.R.V. 2000. Tectonic History of the Borborema Province. In: Umberto Cordani, Edson José Milani, Antonio Thomaz Filho, Diogenes de Almeida Campos. (Org). Tectonic Evolution of South America. v 1, pp. 151-182.

Brown, M., Averkin, Y.A., McLellan, E.L., 1995. Melt segregation in migmatites. Journal of Geophysical Research 100, 15655-15679.

Card, C.D., Bethune, K.M., Davis, W.J., Rayner, N., Ashton, K.E., 2014. The case for a distinct Taltson orogeny: Evidence from northwest Saskatchewan, Canada. Precambrian Research 255, 245-265.

Chappel, B.W., 1984. Source rocks of I- and S-type granites in the Lachlan Fold Belt, southeastern Australia. Philosophical Transections of the Royal Society of London Series 310, 693-707.

Chappel, B.W., White, A.J.R., 2001. Two contrasting granite types: 25 years later. Australian Journal of Earth Sciences 48, 489-499.

Condie, K.C., 2002. Breakup of a Paleoproterozoic supercontinent. Gondwana Research $5,41-43$.

Condie, K.C., 2011. The supercontinent cycle. Earth as an Evolving Planetary System, Academic Press, New York, pp. 317-355.

Cordani, U.G., Sato, K., Teixeira, W., Tassinari, C.C.G., Basei, M.A.S., 2000. Crustal evolution of the South American platform. In: Cordani, U.G., Milani, E.J., ThomazFilho, A., Campos, D.A. (Eds.), Tectonic Evolution of South America, 31st Internartional Geological Congress, Rio de Janeiro, pp. 19-40.

Cox, R.A., Rivers, T., Mapani, B., Tembo, D., DeWaele, B., 2002. New U-Pb data for the Irumide Belt: LA-MC-ICP-MS results for the Luangwa Terrane: In: Nambibia, 
G.S.O. (Eds.), 11th IAGOD Quadrennial Symposium and Geocongress, Windhoek, Namibia, p.3.

Cullers, R.L., Griffin, T., Bickford, M.E., Anderson, J.L., 1992. Origin and chemical evolution of the 1360 Ma San Isabel batholith, Wet Mountains, Colorado: a mid-crustal granite of anorogenic affinities. Geological Society of America Bulletin 104, 316-328.

Dantas, E.L., Souza, Z.S., Wernick, E., Hackspacher, P.C., Martin, H., Xiadong, D., Li, J.W., 2013. Crustal growth in the 3.4-2.7 Ga São José do Campestre Massif, Borborema Province, NE Brazil. Precambrian Research 227, 12-156.

Davies, G.R., Tommasini, S. 2000. Isotopic disequilibrium during rapid crustal anatexis: implications for petrogenetic studies of magmatic processes. Chemical Geology 162, 169-191.

DeWaele, B., Mapani, B., 2002. Geology and correlation of the central Irumide Belt. Journal of African Earth Sciences 25, 285-397.

Eby, G.N., 1992. Chemical subdivision of the A-type granitoids: Petrogenetic and tectonic implications. Geology 20, 641-644.

Evans, D.A.D., 2003. True polar wander and supercontinents. Tectonophysics 362, 303320.

Evans, D.A.D., Mitchell, R.N., 2011. Assembly and breakup of the core of Paleoproterozoic--Mesoproterozoic supercontinent Nuna. Geology 39, 443-446.

Frost, B.R., Barnes, C.G., Collins, W.J., Arculus, R.J., Ellis, D.J., Frost, C.D., 2001. A geochemical classification of granitic rocks. Journal of Petrology 42, 2033-2048.

Frost, C.D., Frost, B.R., 2011. On Ferroan (A-type) Granitoids: their compositional variability and modes of origin. Journal of Petrology 52, 39-53.

Frost, C.D., Frost, B.R., Chaberlain, K.R., Edwards, B.R., 1999. Petrogenesis of the $1.43 \mathrm{Ga}$ Sherman batholith, SE Wyoming: a reduced rapakivi-type anorogenic granite. Journal of Petrology 40, 1771-1802. 
Gióia, S.M.C.L., Pimentel, M.M., 2000. The Sm-Nd isotopic method in the geochronology laboratory of the University of Brasília. Anais da Academia Brasileira de Ciências 72, 219-245.

Goodge, J.W., Myrow, P., Philips, D., Fanning, C.M., Williams, I.S., 2004. Siliciclastic record of rapid denudation in response to convergent-margin orogenesis, Ross orogen, Antarctica. In: Bernet, M., Spiegel, C. (Eds.), Detrital thermochronology - Provenance analysis, exhumation and landscape evolution of mountain belts. Geological Society of America Special Paper 378, p. 101-122.

Harris, N.B.W., Pearce, J.A., Tindle, A.G., 1986. Geochemical characteristics of collision zone magmatism. In: Coward, M.P., Ries, A.C. (Eds.), Collision Tectonics (pp. 67-81). Geological Society of Londo Special Publication.

Hawkesworth, C.J., Dhuime, B., Pietranik, A.B., Cawood, P.A., Kemp., A.I.S., Storey, C.D., 2010. The generation and evolution of the continental crust. Journal of the Geological Society 167, 229-248.

Lages, G.A., Dantas, E.L. 2016. Floresta and Bodocó Mafic-Ultramafic Complexes, western Borborema Province, Brazil: geochemical and isotope constraints for evolution of a Neoproterozoic arc environment and retro-eclogitic hosted Ti-mineralization. Precambrian Research 280, 95-119.

Li, Z.X., Bogdanova, S.V., Collins, A.S., Davidson, A., De Waele, B., Ernst, R.E., Fitzsimons, I.C.W., Fuck, R.A., Gladkochub, D.P., Jacobs, J., Karlstron, K.E., Lu, S., Natapov, L.M., Pease, V., Pisarevsky, S.A., Thrane, K., Vernikovsky, V., 2008. Assembly, configuration, and break-up history of Rodinia: A synthesis. Precambrian Research 160, 179-210.

Mateinni, M., Junges, S.L., Dantas, E.L., Pimentel, M.M., Buhn, B.M., 2009. In situ zircon $\mathrm{U}-\mathrm{Pb}$ and Lu-Hf isotope systematic on magmatic rocks: insights on the crustal evolution of the Neoproterozoic Goiás Magmatic Arc, Brasília belt, Central Brazil. Gondwana Research 16, 200-212.

McMillan, N.J., Harmon, R.S., Moorbath, S., Lopez-Escobar, L., Strong, D.L., 1989. Crustal sources involved in continental arc magmatism: a case study of volcan MochChoshuenco, southern Chile. Geology 17, 1152-1156. 
Meert, J.G., 2002. Paleomagnetic evidence for a Paleo-Mesoproterozoic Supercontinent Columbia. Gondwana Research 5, 207-215.

Meert, J.G., 2012. What's in a name? The Columbia (Paleopangaea/Nuna) Supercontinent. Gondwana Research 21, 987-993.

Mitchell, R.N., Kilian, T.N., Evans, D.A.D., 2012. Supercontinent cycles and the calculation of absolute paleolongitude in deep time. Nature 482, 208-212.

Murphy, J.B., Nance, R.D., 2003. Do supercontinents introvert or extrovert? Sm-Nd Isotopic evidence. Geology 31, 873-876.

Murphy, J.B., Nance, R.D., 2013. Speculations on the mechanism for the formation and breakup of supercontinents. Geoscience Frontiers 4, 185.194.

Nance, R.D., Murphy, D.B., 2013. Origins of the supercontinent cycle. Geoscience Frontiers 4, 439-448.

Neves, S.P., Bruguier, O., Silva, J.M.R., Mariano, G., Da Silva Filho, A.F., Teixeira, C.M.L., 2015. From extension to shortening: dating the onset of the Brasiliano Orogeny in eastern Borborema Province (NE Brazil Journal of South American Earth Sciences $58,238-256$.

Parman, S.W., 2015. Time-lapse zirconography: Imaging punctuated continental evolution. Geochemical Perspective Letters 1, 43-52.

Patiño Douce, A.E., 1997. Generation of metaluminous A-type granites by low pressure melting of calc-alkaline granitoids. Geology 25, 743-746.

Patiño Douce, A.E., Harris, N., 1998. Experimental constraints on Himalayan Anatexis. Journal of Petrology 39, 689-710.

Parente, C.V., Arthaud, M.H., 1995. O sistema Orós-Jaguaribe no Ceará-NE do Brasil. Revista Brasileira de Geociências 25, 297-305.

Pearce, J.A., 1982. Trace elements characteristics of lavas from destructive plate boundaries. In: Thorpe, R.S. (Ed.), Andesites. John Wiley and Sons, London, pp. 525548. 
Rapp, R.P., Watson, E.B., 1995. Dehydration melting of metabasalt at 8-32 kbar: implications for continental growth and crust- mantle recycling. Journal of Petrology 36, 891-931.

Reddy, S.M., Evans, D.A.D., 2009, Palaeoproterozoic supercontinents and global evolution: Correlations from core to atmosphere, in Reddy, S.M., et al., eds., Palaeoproterozoic supercontinents and global evolution: Geological Society of London Special Publication 323, p. 1-26.

Rivers, T., 2012. Upper-crustal orogenic lid and mid-crustal core complexes: signatures of a collapsed orogenic plateau in the hinterland of the Grenville Province. Canadian Journal of Earth Sciences 49, 1-42.

Rizzotto, G.J., Quadros, M.L., 2005. Geologia do Sudoeste do Cráton Amazônico. In: Horbe, Adriana; Souza, Valmir da Silva (Orgs.). Contribuições à Geologia da Amazônia. 69-84.

Rogers, J.J.W., Santosh, M., 2002. Configuration of Columbia, a Mesoproterozoic supercontinent. Gondwana Research 5, 5-22.

Rogers, J.J.W., Santosh, M., 2009. Tectonics and surface effects of the supercontinent Columbia. Gondwana Research 15, 373-380.

Rollinson, H., 1993. Using geochemical data: evaluation, presentation, interpretation. Longman Scientific \& Thecnical, New York, Essex, p. 344.

Ruiz, A.S., Geraldes, M.C., Matos, J., Teixeira, W., Van Schmus, W.R., Schmitt, R.S., 2004. The 1590-1520 Ma Cachoeirinha magmatic arc and its tectonic implications for the Mesoproterozoic SW Amazonian craton crustal evolution. Anais da Academia Brasileira de Ciências 76, 808-824.

Sá, J.M., Bertrand, J.M., L., Leterrier, J., Macedo, M.H.F., 2002. Geochemistry and geochronology of pre-Brasiliano rocks from the Transversal Zone, Borborema Province, Northeast Brazil. Journal of South American Earth Sciences 14, 851-866.

Sá, J.M., Sousa, L.C., Legrand, J.M., Galindo, A.C., Maia, H.N., Fillipi, R.R., 2014. U$\mathrm{Pb}$ and $\mathrm{Sm}-\mathrm{Nd}$ data of the Rhyacian and Statherian orthogneisses from Rio Piranhas- 
Seridó and Jaguaribeano Terranes, Borborema Province, Northeast of Brazil. Geologia USP - Série Científica 14, 97-110.

Santos, E.J., Medeiros, V.C., 1999. Constraints from granitic plutonism on proterozoic crustal growth of the Transverse Zone, Borborema Province, NE-Brazil. Revista Brasileira de Geociências 29, 73-84.

Santos, A.C.L., Padilha, A. L., Fuck, R. A., Pires, A. C. B., Vitorello, I.,Pádua, M. B. 2014. Deep structure of a stretched lithosphere: Magnetotelluric imaging of the southeastern Borborema province, NE Brazil. Tectonophysics 610, 39-50, 2014.

Santos, E.J., Brito Neves, B.B., Van Schmus, W.R., Oliveira, R.G., Medeiros, V.C., 2000. An overall view on the displaced terrane arrangement of the Borborema Province, NE Brazil. In: International Geological Congress, 31th, Rio de Janeiro, Brazil, General Symposia, Tectonic Evolution of South American Platform, pp. 5-9.

Santos, E.J., Van Schmus,W.R., Kozuch, M., Brito Neves, B.B., 2010. The Cariris Velhos tectonic event in northeast Brazil. J. South Am. Earth Sci. 29, 61-76.

Santos, L.C.M.L., Dantas, E.L., Santos, E.J., Santos, R.V., Lima, H.M., 2015. Early to late Paleoproterozoic magmatism in NE Brazil: the Alto Moxoto Terrane and its tectonic implications for the pre-West Gondwana assembly. Journal of South American Earth Sciences.58, 188-209.

Santosh, M., Zhao, G., 2009. Supercontinent dynamics. Gondwana Research 15, 225227.

Scandolara, J.A., Fuck, R.A., Dantas, E.L., Souza, V.S., 2013. Geochemistry of Jamari Complex, central-eastern Rondônia: Andean type magmatic arc and Paleoproterozoic crustal growth of the southwestern Amazonian Craton, Brazil. Journal of South American Earth Sciences 41, 1-28.

Stevens, G., Clemens, J.D., Droops, G.T.R., 1997. Melt production during granulitefacies anatexis: experimental data from primitive metasedimentary protoliths. Contributions to Mineralogy and Petrology 128, 352-370.

Streckeisen, A.L., 1976. To each plutonic rocks its proper name. Earth Science Reviews $12,1-33$. 
Tassinari, C.C.G., Cordani, U.G., Nutman, A.P., Van Schmus, W.R., Bettencourt. J.S., Taylor, P.N., 1996. Geochronological systematics on basement rocks from the Rio Negro-Juruena province (Amazonian craton) and tectonic implications. International Geology Review 38, 161-175.

Tassinari, C.C.G., Macambira, M.J.B., 1999. Geochronological provinces of the Amazonian craton. Episodes 22, 174-182.

Trap, P., Faure, M., Lin, W., Breton, N.L., Breton, P. Monié., 2012. Paleoproterozoic tectonic evolution of the Trans-North China Orogen: toward a comprehensive model. Precambrian Research 222, 191-211.

Trompette, R., 1994. Geology of Western Gondwana, Pan African-Brasiliano Aggregation of South America and Africa. A.A. Balkema, Rotterdam, p. 350.

Van Scmmus, W.R., Oliveira, E.P., Silva Filho, A.F., Toteu, F., Penaye, J., Guimarães, I.P., 2008. Proterozoic links between the Borborema Province, NE Brazil, and the Central African Fold Belt. Geological Society of London Special Publication 294, 6669.

Whalen, J.B., Currie, K.L., Chappel, B.W., 1987. A-type granites: geochemical characteristics, discrimination and petrogenesis. Contributions to mineralogy and petrology 95, 407-419.

Windley, B., 1992. Precambrian Europe. In Blundell, D., Freeman, R., \& Mueller S. (eds.). A continent Revealed: The European Geotraverse, 139-152. Cambridge University Press, Cambridge, U.K.

Zhao, G.C., Suna, M., Simon, A.W., Sanzhong, L., 2004. Paleo-Mesoproterozoic supercontinent: assembly, growth and breakup. Earth Science Reviews 67, 91-123.

Zhao, G., Sun. M., Wilde, S., Li, S., 2005. Late Archean to Paleoproterozoic evolution of the North China Craton: key issues revisited. Precambrian Research 136, 177-202. 


\title{
6. ARTIGO CIENTÍFICO 4:
}

\section{Sm-Nd ISOTOPE MAPPING OF TERRANES IN THE TRANSVERSAL SUBPROVINCE OF THE BORBOREMA PROVINCE, NE BRAZIL: IMPLICATIONS FOR ACCRETION TECTONICS IN WEST GONDWANA.}

Lauro Cézar Montefalco de Lira Santos ${ }^{1,2, *}$; Elton Luiz Dantas ${ }^{1}$; Peter A. Cawood³; Edilton José dos Santos ${ }^{4}$, Reinhaddt A. Fuck ${ }^{1}$, Haroldo Monteiro Lima ${ }^{1}$; Geysson de A. Lages

${ }^{1}$ Instituto de Geociências, Universidade de Brasília, Brazil; ${ }^{2}$ Unidade Acadêmica de Mineração e Geologia, Universidade Federal de Campina Grande, Brazil; ${ }^{3}$ Department of Earth Sciences, University of St. Andrews, UK; ${ }^{4}$ Serviço Geológico do Brasil CPRM, Brazil.

*Corresponding author. E-mail: lauromontefalco@gmail.com

\begin{abstract}
Whole-rock Sm-Nd isotope mapping of metaplutonic and metasedimentary rocks in the Tranversal Sub Province of the Borborema Province (central West Gondwana) are used to verify whether Neoproterozoic terrane assembly took place, as well as the role of crustal processes in the region. Such rocks are ascribed in the literature as being part of the Neoproterozoic Alto Pajeú and Archean-Paleoproterozoic Alto Moxotó terranes, which are limited by the Serra de Jabitacá thrust shear zone, considered as the main terrane boundary. The distribution of $\mathrm{T}_{\mathrm{DM}}$ model ages on histograms and gridded maps revealed contrasting isotopic sources. The older terrane show model ages ranging from Paleoarchean to Paleoproterozoic, whereas the younger one present model ages ranging from Late-Paleoproterzoic to Mesoproterozoic. The contrasting ages is even more evident away from the terrane boundary. Calculated $[\varepsilon \mathrm{Nd}(\mathrm{t})]$ parameter using well known U-Pb zircon ages of the literature, also revealed a complex tectonic scenario. First manifestations of crustal growth are evident in Neoarchean TTG of the Alto Moxotó Terrane. This terrane was then submmited to severe crustal reworking during Early to Late Paleoproterozoic times. On the other hand, the tectonic evolution of the Alto Pajeú Terrane seems to be considerably younger, represented by Neoproterozoic
\end{abstract}


reworking of a old crust during the Cariris Velhos (1025-900 Ma) orogeny. The usage of our large $\mathrm{Nd}$ dataset indicate that the Serra de Jabitacá shear zone separate two distinct crustal blocks constrained by different isotopic behaviors, thus, marking the onset of terrane collage in this portion of West Gondwana.

Key-words: Sm-Nd isotope mapping, Accretion tectonics, Borborema Province

\subsection{Introduction}

Over the last decades, the application of radiogenic isotopes on regional geology studies has strongly contributed to the understanding of Earth's history and evolution. Among a plenty of available isotope parent-daughter tracers, the samarium-neodymium (Sm-Nd) method, provides irrefutable insights on crust and mantle processes. Once that $\mathrm{Sm}$ and $\mathrm{Nd}$ are geochemically similar, their behavior during formation and modification of continental and oceanic crust is relatively predictable (DePaolo, 1981). For instance, $\mathrm{T}_{\mathrm{DM}}$ model ages and the $[\varepsilon \mathrm{Nd}(\mathrm{t})]$ parameter are powerful tools for the investigation of age and nature of lithospheric sources as well as markers of crust-mantle segregation and late differentiation processes (DePaolo and Wasserburg, 1976; Bennet and DePaolo, 1987).

Accretionary orogens correspond to complex tectono-magmatic settings, where crustal terranes are assembled to an active continental margin (Schermer et al., 1984; Howell, 1995). They can be recognized since the Archean and are associated to the major events of crustal growth of Earth's History (Cawood et al., 2007, 2009, 2011). Once that systematic episodes of crustal shortening may take place, early structures and original stratigraphic record may be partialor completely obliterated by crustal reworking of last tectonic overprint. In this sense, given that the $\mathrm{Nd}$ isotopic signature does not present significant variations during metamorphism and weathering, the Sm$\mathrm{Nd}$ method is a powerful tool for mapping terranes in Precambrian orogens that were submitted to severe deformation and posterior exhumation (eg. Champion and Cassidy, 2008; Schoene et al., 2009; Zelek and Dickin, 2013).

The Borborema Province (BP) in NE Brazil occupies a privileged position in the central portion of West Gondwana. It is part of a long orogenic belt that find continuity 
in the African continent (Brito Neves et al., 2000). In this region, geophysical, structural and geochronological data led some authors to suggest that terrane assembly took place in early to late Neoproterozoic, resulting in the formation of magmatic arcs and possible suture zones (Santos, 1996; Santos and Medeiros, 1999; Santos et al., 2010; Van Schmus et al., 2011; Brito Neves et al., 2014). In recent years, geophysical investigations based on several methods have precisely defined the position of the main terrane boundaries, which are geographically coincident with regions of crustal growth (Correia et al., 2015; Lima et al., 2015; Padilha et al., 2016). On the other hand, Neves (2015) has challenged the accretionary model, suggesting instead that the whole province corresponds to an intracontinental orogen that is stabilized since the Paleoproterozoic ages.

Aiming to contribute to the discussion on the evolution of this province, we analyzed an amount of one hundred and six (106) rock samples of metaplutonic and metasedimentary rocks in parts of the Neoproterozoic Alto Pajeú and ArcheanPaleoproterozoic Alto Moxotó terranes focused on Transversal Sub province.Once that these terranes are limited by an important proposed structural thrust boundary, our main goal is to verify whether there are contrasting isotopic signatures among them. In addition, we use $\mathrm{Nd}$-isotopic mapping and calculated $\varepsilon \mathrm{Nd}(\mathrm{t})$ values to evaluate the extent of crustal growth and reworking in the region and their significance for the West Gondwana evolution.

\subsection{Geological setting}

The Borborema Province (NE Brazil) constitutes the northeastern portion of the Precambrian South American platform (Almeida et al., 1981). It can be traced into the African continent through Benin, Nigeria and Cameroon, occupying the central part of West Gondwana (Figure 6.1; Brito Neves 1975; Trompette, 1994; Van Schmus et al., 2008). One of its main features is its internal structural complexity, that is characterized by a network of NE-SW and E-W shear zones, that forms up to several kilometers-wide of mylonitic corridors that are connected to suture zones in West-Africa (Vauchez et al., 1995; Archanjo et al., 2008; Oliveira, 2008; Brito Neves et al., 2014). In addition, it is assumed that this province is the result of the convergence between the Amazonian-São 
Luiz-West-Africa and the São Francisco-Congo Cratons during the Neoproterozoic Brasiliano-Pan African orogeny (Brito Neves et al., 2000, 2014).

The province comprises domains of highly deformed Paleoproterozoic rocks, locally including some Archean fragments (Santos et al., 2000; Fetter et al., 2000; Arthaud et a., 2008; Van Schmus et al., 2008; Dantas et al., 2013; Costa et al., 2015), that are interleaved with early to late Neoproterozoic metavolcanosedimentary belts (Van Schmus et al., 2003; Hollanda et al., 2015) and Tonian to Ediacaran continental crust containing mainly granitic components (Santos and Medeiros, 1999; Araújo et al., 2014; Santos et al., 2010; Brito Neves et al., 2014). The general tectonic division of the province is composed by the northern, transversal (or central) and southern Sub provinces (Van Schmus et al., 1995, 2011; Santos and Medeiros, 1999; Brito Neves et al., 2000). According to these authors, they record a polycyclic Neoproterozoic history of accretion and collision-related events resulting in a complex mosaic of tectonostratigraphic terranes. Similar tectonic episodes are described in the African counterpart of the province, especially along the Trans-Saharan belt between the Hoggar Shield and Benin-Nigerian Province (Black et al., 1994; Liégois et al., 1994, 2003).

The Transversal Sub province is divided into five terranes: São José do Caiano, Piancó-Alto Brígida, Alto Pajeú, Alto Moxotó and Rio Capibaribe (Santos and Medeiros, 1999; Brito Neves et al., 2000). The Alto Pajeú Terrane is separated from the Piancó-Alto Brígida Terrane to the northwest by the strike-slip NE-SW Serra do Caboclo shear zone, and from the Alto Moxotó Terrane by the Serra de Jabitacá thrust system. Its main rock association includes supracrustal volcano-sedimentary sequences and calc-alkaline granites with minor eclogitic affinity mafic-ultramafic rocks (Santos, 1995; 2000; Lages and Dantas, 2016). The terrane is interpreted to be generated via accretion of Tonian magmatic arcs that were amalgamated during the Cariris Velhos orogeny (ca. 1.0-0.96 Ga, Kozuch, 2003; Santos et al., 2010; Lages and Dantas, 2016). Lastly, minor Ediacaran granites intruded the terrane during the Brasiliano orogeny (Santos and Medeiros, 1999; Araújo et al., 2014; Brito Neves et al., 2014). In constrast, the Alto Moxotó Terrane corresponds to a high-grade metamorphic crustal block composed of orthogneisses, migmatites, metagranites and mafic-ultramafic rocks coupled with supracrustal sequences that experienced Paleoproterozoic accretion and collision events between 2.6 to 1.9 Ga (Brito Neves et al., 1995; Santos et al., 2004; 
Santos et al., 2015a, 2016, in revision). Its boundary with the southern Sub province is the Pernambuco Lineament in the west and the Congo Cruzeiro do Nordeste strike-slip shear zone in the east with Rio Capibaribe terrane (Brito Neves et al., 2000; Santos et al., 2000). The terrane lacks evidence for the Cariris Velhos orogeny and Brasilianorelated granites are scarce, being restricted to Cambrian A-type granites are present along the margins of the terrane (Guimarães et al., 2005 and references therein).

The study area, is located on boundary between the Alto Pajeú and Alto Moxotó terranes near the Airi town, Pernambuco. In this region, orthogneisses and supracrustal sequences predominate (Figure 6.2). Rocks from the Alto Moxotó Terrane are Archean and Paleoproterozoic in age, with the represented by the ca. 2.6 Ga Riacho das Lajes TTG Suite, forming gneissic to migmatitic fabrics (Figure 6.3a). Banded granitic to tonalitic orthogneisses of the Floresta Suite (Figure 6.3b) are Rhyacian (ca. 2.1 Ga), whereas, augen-gnaisses and highly deformed granitic rocks (Figure 3d) occur in the northern portion of the terrane, presenting an ca. $1.6 \mathrm{Ga}$ protolith crystallization age, being referred as Riacho do Navio orthogneisses. Local occurrences of metagabbro lenses (Figure 6.3e) and biotite-paragneisses with local quartz-feldspatic anatetic zones (Figure 6.3f) are attributed to the $1.9 \mathrm{Ga}$ Malhada Vermelha Suite and Sertânia Complex respectively.

In turn, in the Alto Pajeú Terrane metaplutonic units crosscut a sequence of supracrustal rocks. The former include occurrences of calc-alkaline metaplutonites with granitc to granodioritic composition of the São Pedro Suite (Figure 6.3f) and maficultramafic sequences of the Serrote das Pedras Pretas Suite, including metaperidotites, metapyroxenites, metahornblendites and garnet-metagabbros (Figure 3g). In addition, supracrustal rocks are referred as São Caetano Complex, which is mostly characterized by metavolcanic rocks including altered metabasalts and biotite-muscovite paragneisses (Figure 6.3h). The main $\mathrm{U}-\mathrm{Pb}$ in zircon ages attributed for this set of rocks range from 1025 to 900 Ma (Santos, 1995; Kozuch, 2003; Santos et al., 2010; Guimarães et al., 2012; Lages and Dantas, 2016). At last, Ediacaran granites occur in the northern portion of the terrane being interpreted as the result of crustal anatexis during the Brasiliano orogeny at ca. $650 \mathrm{Ma}$ (Santos and Medeiros, 1999). 


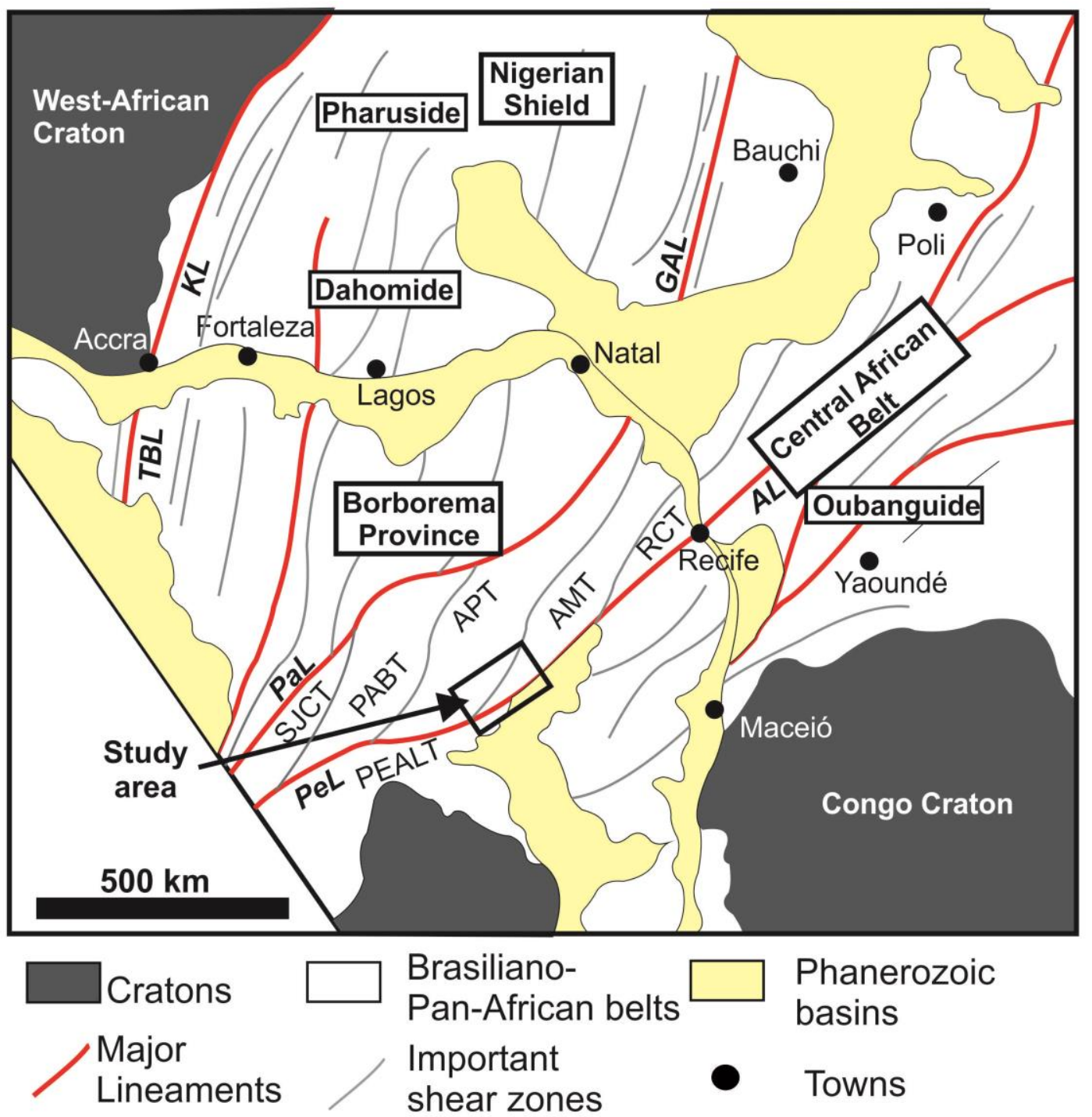

Figure 6.1 - a) Pre-drift reconstruction of Northeast South America and West Africa in West Gondwana context with the main structural provinces and lineaments. SJCT = São José do Caiano Terrane, PABT = Piancó Alto-Brigída Terrane, APT = Alto Pajeú Terrane, $\mathrm{AMT}=$ Alto Moxotó Terrane, $\mathrm{RCT}=$ Rio Capibaribe Terrane, $\mathrm{TBL}=$ Transbrasiliano Lineament, KL - Khandi Lineament, PaL = Patos Lineament, GAL = Garoua Lineament, PeL = Pernambuco Lineament, $\mathrm{AL}=$ Adamoua Lineament. 


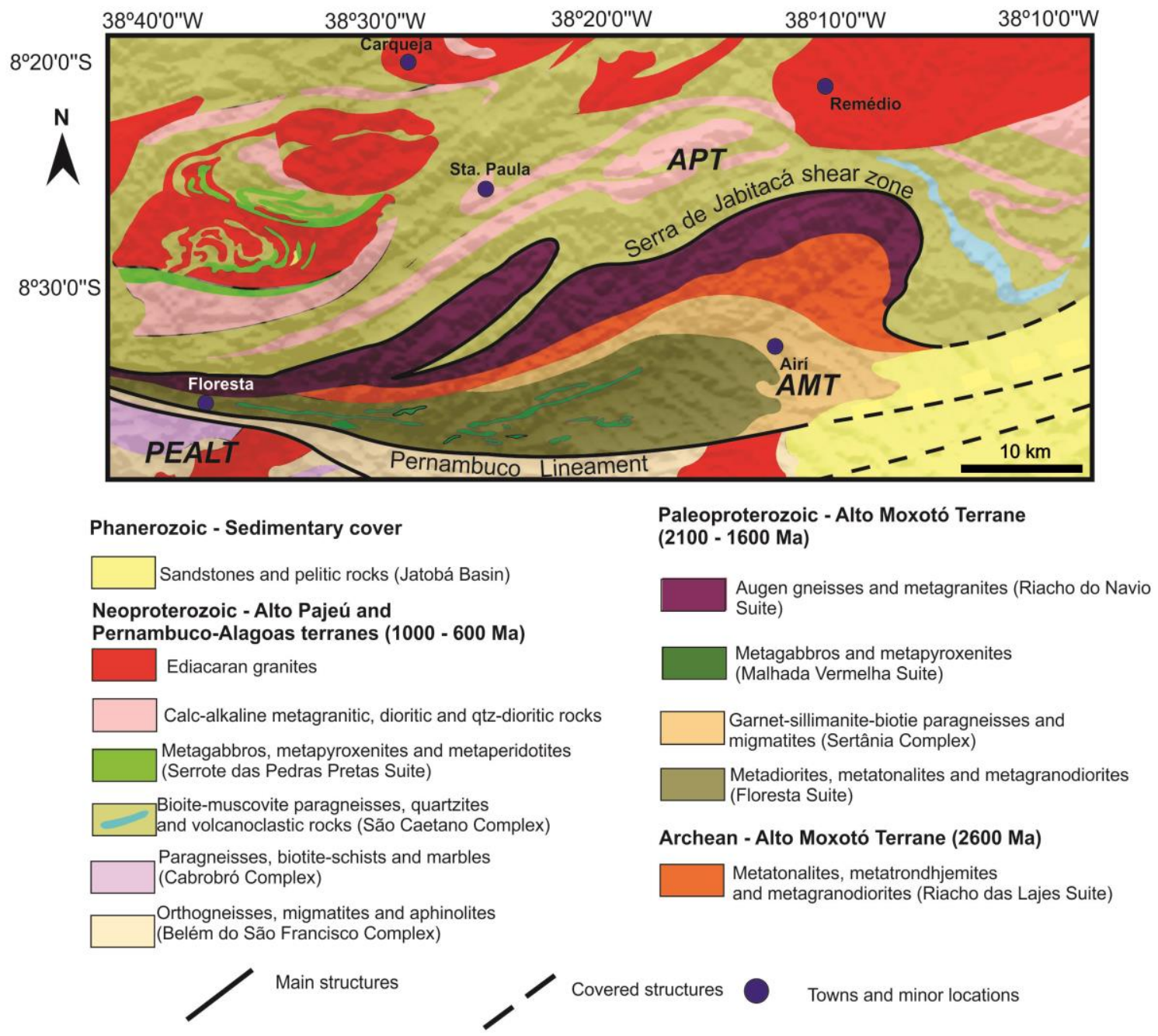

Figure 6.2 - Geological map of the study area. Terranes: APT = Alto Pajeú, AMT = Alto Moxotó. PEALT means Pernambuco-Alagoas Terrane, which is not addressed in this paper. 

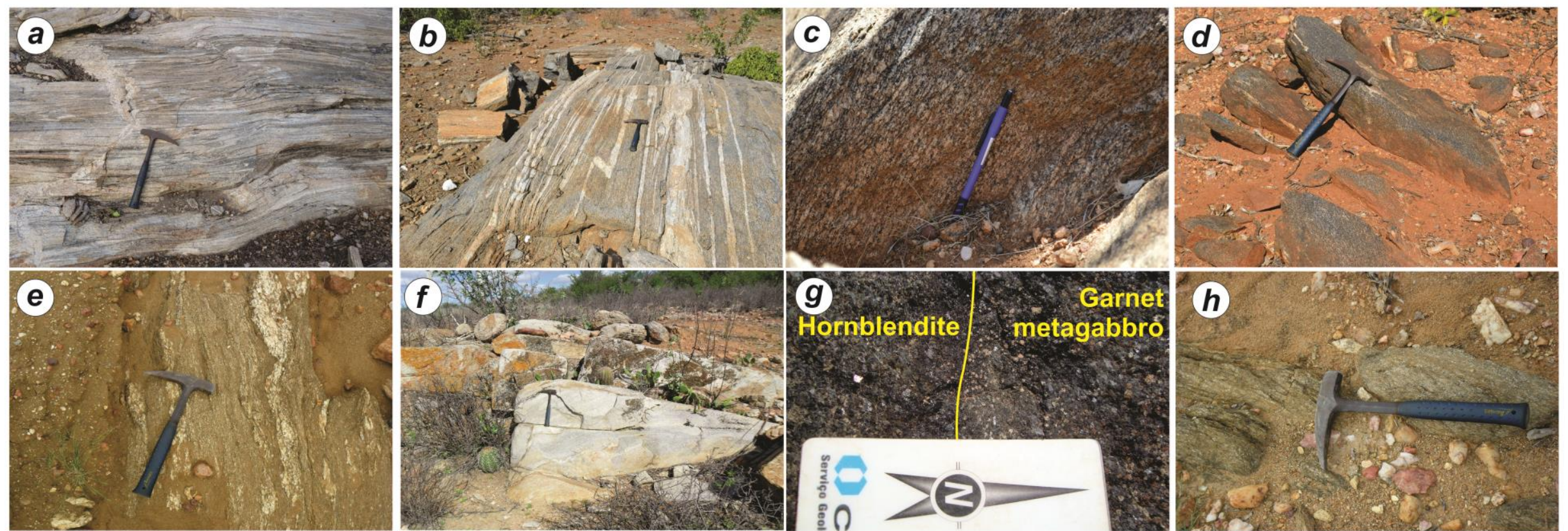

Figure 6.3 - Field aspects of the main outcropping units of the studied terranes. Alto Moxotó Terrane: a) migmatized orthogneiss of tonalitic composition of the Riacho das Lajes Suite; b) Banded granodioritic orthogneiss of the Floresta Suite; c) highly deformed Riacho do Navio augen gneiss; d) tabular lens of mettagabro of the Malhada Vermelha Suite; e) migmatized biotite-paragneiss with local quartz-feldspar mobilized. Alto Pajeú Terrane; f) isotropic tonian tonalitic granite of the São Pedro Suite; g) contact zone between metahornblendite and garnet metagabbro of the Serrote das Pedras Pretas Suite; h) muscovite-bearing paragneiss of the São Caetano Complex. 


\subsection{Rock sampling and analytical procedures}

The adopted systematic of rock sampling was based on the distribution of accessible outcrops of orthogneisses and supracrustal rocks of both terranes, once our intention is to characterize the nature crust of the proposed terrane-boundary as well as the averageprovenance sources of metasedimentary rocks. For this study, only fresh and representative samples of each unit were analyzed.

After the removal of eventual weathered portions, an average of $4 \mathrm{~kg}$ of rock was crushed and pulverized to a most representative fine powder. The samples were analyzed following the method described by Gióia and Pimentel (2000). Whole rock powders (ca. $50 \mathrm{mg}$ ) were mixed with a ${ }^{149} \mathrm{Sm}^{-150}{ }^{15 d}$ spike solution and dissolved in Savillex capsules. The extraction of $\mathrm{Sm}$ and $\mathrm{Nd}$ from whole-rock samples followed conventional cation exchange techniques using Teflon columns containing LN-Spec resin (HDEHP - diethylhexyl phosphoric acid supported on PTFE powder). The Sm and $\mathrm{Nd}$ samples were loaded on Re evaporation of double-filament assemblies, and the isotopic measurements were also performed on a multi-collector Triton Plus, Thermoscientific mass spectrometer in the static mode at the University of Brasilia.

The uncertainties in the $\mathrm{Sm} / \mathrm{Nd}$ and ${ }^{143} \mathrm{Nd} /{ }^{144} \mathrm{Nd}$ ratios are better than $\pm 0.4 \%$ (1 $\sigma)$ and $\pm 0.005 \%(1 \sigma)$, respectively, based on repeated analyses using the international rock standards BHVO-1 and BCR-1. The ${ }^{143} \mathrm{Nd} /{ }^{144} \mathrm{Nd}$ ratios were normalized to a ${ }^{146} \mathrm{Nd} /{ }^{144} \mathrm{Nd}$ of 0.7219 , and the used decay constant was $6.54 \times 10^{-12}$. T DM model age values were calculated using the DePaolo (1981) model. The presented $\mathrm{T}_{\mathrm{DM}}$ isotopic map presented in this study was gridded by ordinary statistics kriging techniques in Surfer (Golden Software), v. 13. The results of Sm-Nd analyses as well as the U-Pb zircon ages used to calculate the $\varepsilon \mathrm{Nd}(\mathrm{t})$ values and their references are shown in tables 6.1 and 6.2 .

\subsection{Results}

The obtained data are characterized by a strong contrast on the $\mathrm{Nd}$ isotopic composition of the studied terranes. The depleted-mantle $\left(\mathrm{T}_{\mathrm{DM}}\right)$ model ages histogram for metaplutonic rocks of the Alto Moxotó Terrane present values with a large age span, ranging from 1.90 to $3.34 \mathrm{Ga}$, with two major peaks at 2.5 and $2.9 \mathrm{Ga}$ (Figure 6.4a). On 
the other hand, samples from the Alto Pajeú Terrane are characterized by considerably younger model ages, ranging from 1.62 to $2.05 \mathrm{Ga}$, with a major peak at around $1.9 \mathrm{Ga}$. Nevertheless, supracrustal rocks of both terranes show a bimodal model age distribution. Samples from the Alto Moxotó Terrane ranges from 1.90 to $3.19 \mathrm{Ga}$, whereas those from the Alto Pajeú Terrane ranges from 1.36 to $1.96 \mathrm{Ga}$. The major peaks on the histogram are. $2.7 \mathrm{Ga}$, and $1.9 \mathrm{Ga}$, for the Alto Moxotó and Alto Pajeú terranes, respectively (Figure 6.4b).

Such diachronic source-related ages can be also observed on the latitude versus $\mathrm{T}_{\mathrm{DM}}$ plot (Figure 6.4a). For instance, rocks from the Alto Pajeú Terrane show an abrupt increase of model ages southward as approaching to the proposed terrane boundary. Additionally, in spite of some scattering, samples from the Alto Moxotó Terrane are also characterized by an increasing of the source ages with the latitude, in which younger model ages occur close to the terrane boundary. The observed isotopic variations can also be analyzed on the model ages versus $\mathrm{U}-\mathrm{Pb}$ zircon ages plot, which indicate that the older sources are present in the oldest crustal block (i.e. the Alto Moxotó Terrane (Figure 6.5b).

The geographic model ages distribution on the gridded Nd $\mathrm{T}_{\mathrm{DM}}$ map, allow us to define five groups of source ages, that can be easily related to the known geological units (see Figure 6.6 and 7.2 for comparrison). Groups 1 and 2 are concentrated in the Alto Pajeú Terrane. The former is composed of rocks with $\mathrm{T}_{\mathrm{DM}}$ model ages ranging from 1.3 to $1.7 \mathrm{Ga}$, that occupies the NW portion of the study area. This region is correlated to supracrustal and metamafic-ultramafic rocks of the São Caetano Complex and Serrote das Pedras Pretas Suite respectively. Close to the proposed terrane boundary, samples from group 2, correspond to metasedimentary and calc-alkaline metagranitic rocks and exhibit $\mathrm{T}_{\mathrm{DM}}$ model ages ranging from 1.7 to $2.1 \mathrm{Ga}$. Alternatively, groups 3 and 4 are older spatially associated. The former is characterized by $\mathrm{T}_{\mathrm{DM}}$ model ages ranging from 2.1 to $2.5 \mathrm{Ga}$, which occurs close to the terrane boundary and in central portion of the Alto Moxotó Terrane. The main rock associations are concentrated in the eastern portion of metagranitic rocks and throughout Statherian orthogneisses of the Floresta and Riacho do Navio units, respectively. Nevertheless, group 4 is most representative in this terrane, including Riacho das Lajes metagranitic rocks as well as part of Floresta Suite and metasedimentary rocks of the Sertânia Complex. This group is characterized by $\mathrm{T}_{\mathrm{DM}}$ model ages that range from 2.5 to $2.9 \mathrm{Ga}$. 
Lastly, the oldest $\mathrm{T}_{\mathrm{DM}}$ model ages are located in the southernmost portion of the area, which is considerably distant from the proposed terrane boundary between the studied terranes. They are older than $2.9 \mathrm{Ga}$ and are limited to rocks from Paleoproterozoic metagranitic rocks, including to samples with abnormally old ages of 3.2 and $3.4 \mathrm{Ga}$.

Taking into account the distribution of the calculated $\varepsilon \mathrm{Nd}(\mathrm{t})$ values of metaplutonic rocks, it is possible to constrain the nature of the crust processes that took place in the area (Figure 6.7). On the Alto Moxotó Terrane, Neoarchean rocks present $\varepsilon \mathrm{Nd}(\mathrm{t})$ values close to the CHUR, ranging from $-2,35$ to +0.93 . Though, Rhyacian metaplutonic mafic and felsic rocks are characterized by a strong fluctuation on the $\varepsilon \mathrm{Nd}(\mathrm{t})$ values, ranging from -12.03 to +6.10 and -10.02 to 1.45 , respectively. In addition, Sthaterian metaplutonic rocks are characterized by a strong crustal component with the absence of mantle material input, with $\varepsilon N d(t)$ values ranging from -15.25 to 3.39. Additionally, metamafic and metagranitic rocks of the Alto Pajeú Terrane, show a heterogeneous distribution on the $\varepsilon \mathrm{Nd}(\mathrm{t})$ values, varying from from -8.72 to +0.20 and -10.63 to -3.62 , respectively. 

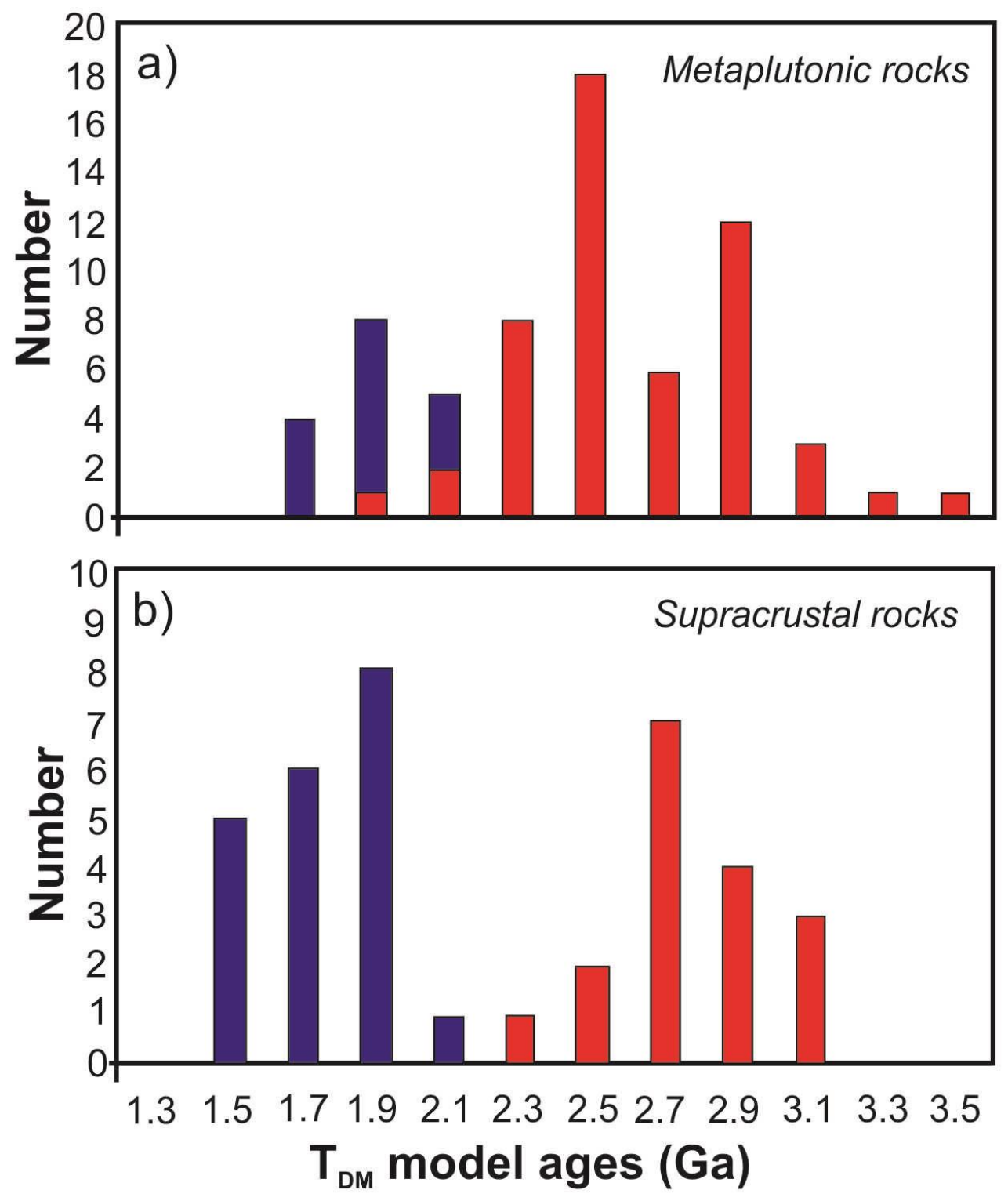

Alto Pajeú Terrane
Alto Moxotó Terrane

Figure 6.4 - Histogram of neodymium depleted mantle model ages ( $\mathrm{T}_{\mathrm{DM}}$ ) for metaplutonic and metasedimentary rocks of the Alto Pajeú and Alto Moxotó Terranes. 

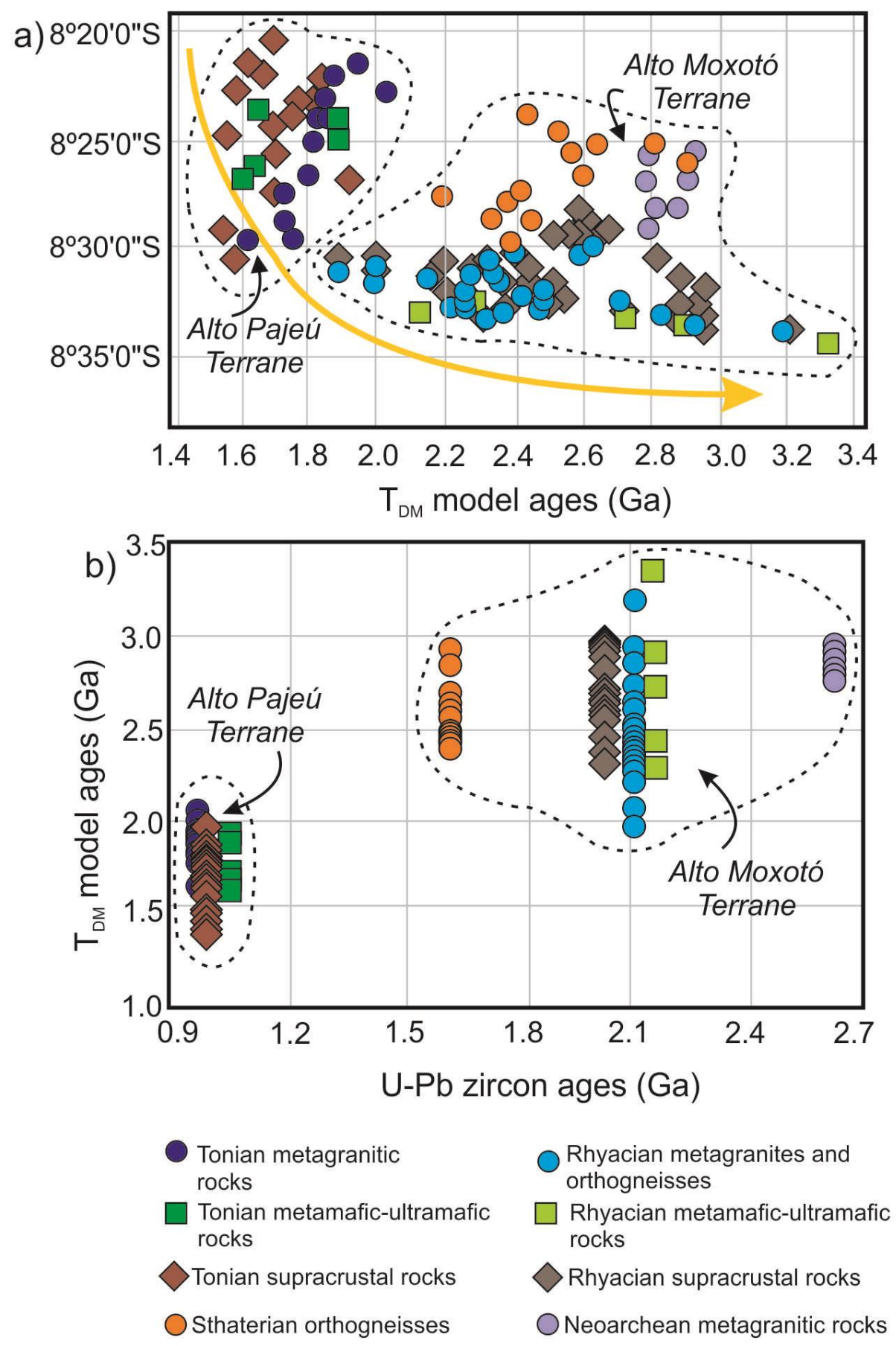

Figure 6.5 - a) Depleted mantle model ages ( $\left.\mathrm{T}_{\mathrm{DM}}\right)$ versus latitude and b) U-Pb zircon ages versus $\mathrm{T}_{\mathrm{DM}}$ ages of metaplutonic and metasedimentary rocks of the Alto Pajeú and Alto Moxotó terranes. The orange arrow in a) show a general trend of increasing model ages with the latitude. 


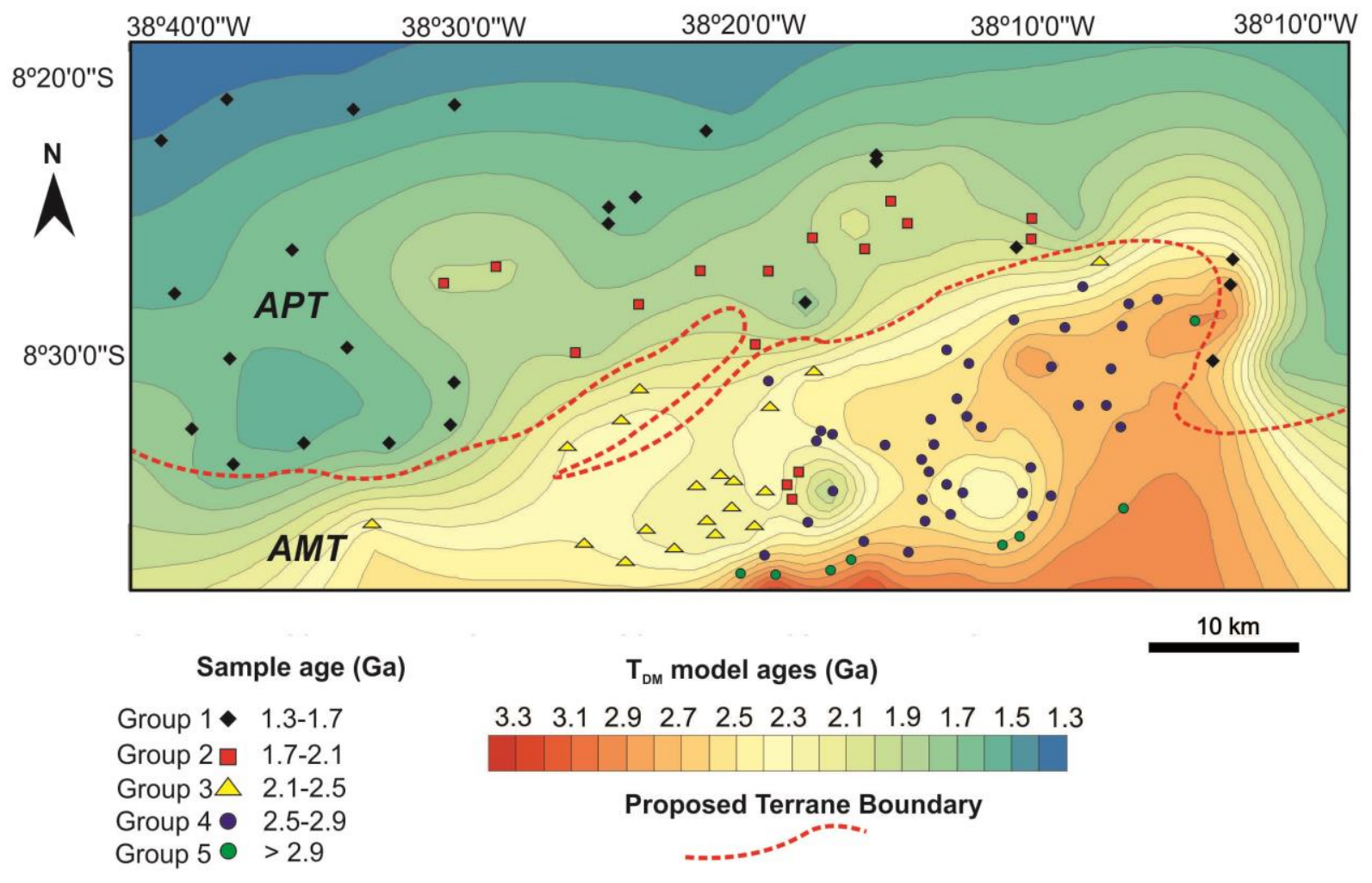

Figure 6.6 - Gridded Nd depleted mantle model age $\left(\mathrm{T}_{\mathrm{DM}}\right)$ map of the study region.

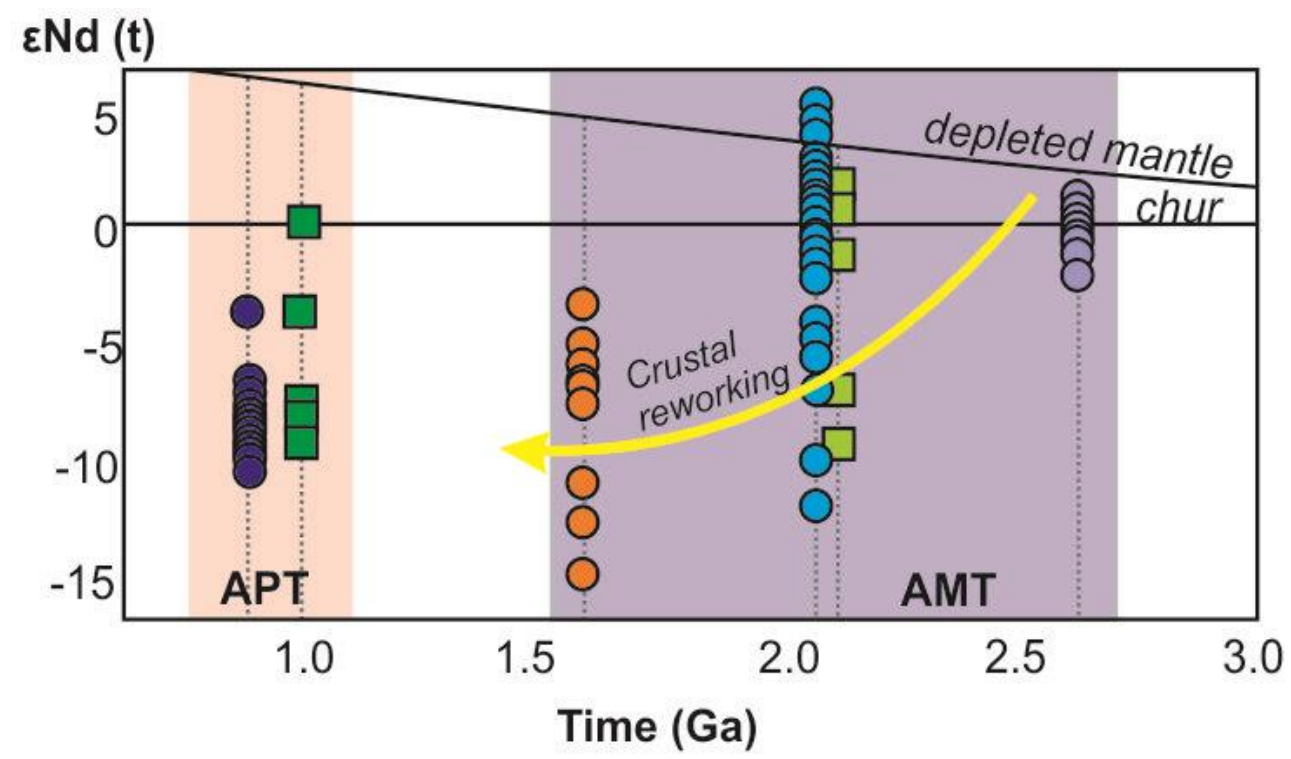

Figure $6.7-\varepsilon N d(t)$ versus $\mathrm{U}-\mathrm{Pb}$ crystallization ages diagram of the studied terranes. Symbols are the same of Figure 5. APT $=$ Alto Pajeú Terrane, AMT = Alto Moxotó Terrane. Simbols are the same as Figure 6.5. 


\subsection{Discussion}

\subsubsection{Nature and source ages}

In order to evaluate the role of crustal processes on the genesis of the studied rocks, we investigate the distribution of $\mathrm{T}_{\mathrm{DM}}$ model ages and the range of $\varepsilon \mathrm{Nd}(\mathrm{t})$ on well mapped metaplutonic and metasedimentary rocks of the Neoproterozoic Alto Pajeú and Archean-Paleoproterozoic Alto Moxotó terranes of the Borborema Province. These units are separated from each other by the Serra de Jabitacá Shear Zone, which is ascribed as the terrane boundary (Santos and Medeiros, 1999; Santos et al., 2016, in revision).

In the Alto Moxotó Terrane, the 2.6 Ga TTG rocks of the Riacho das Lajes Suite metaplutonic rocks present positive to slightly negative $\varepsilon N d(t)$ values and $T_{D M}$ model ages ranging from 2.7 to $2.9 \mathrm{Ga}$, indicating juvenile magmatism in the region, in spite of some reworking of a previous formed Archean crust. These rocks record the first recognized crustal growth event of the terrane. Strongly negative to positive values of $\varepsilon \mathrm{Nd}(\mathrm{t})$ of the Rhyacian rocks of the Floresta Suite probably reflect a mixing of mantle and crustal components. This mixing of sources is also reflected on the wide range of model ages from Rhyacian to Paleoarchean, thus indicating reworking of a long-lived old lithospheric fragment with juvenile inputs as well. Lastly, the $1.6 \mathrm{Ga}$ Riacho do Navio Suite represents a major event of crustal reworking on the terrane, which is reflected by very negative $\varepsilon \mathrm{Nd}(\mathrm{t})$ values, confirmed by much older isotopic model ages. Additionally, metaplutonic rocks of the Alto Pajeú Terrane are characterized by model ages ranging from Meso- to Late Paleoproterozoic, thus indicating young sources as compared to those from the previous terrane, besides a cluster of $\varepsilon \mathrm{Nd}(\mathrm{t})$ ranging from slightly to strongly negative values. Such data indicates a crustal contamination during the ascent of the magma, in spite of minor juvenile contribution observed in mafic and ultramafic rock members.

The diachronic pattern of terrane sources is suggestive that they were generated by different isotopic behaviors. Indeed, the obtained $\mathrm{U}-\mathrm{Pb}$ crystallization ages as well as petrological and structural studies already pointed a contrasting origin (Santos and Medeiros, 1999; Brito Neves, 2000; Santos et al., 2004; Van Schmus et al., 2011; Santos et al., 2016, in revision). Hence, if we take into account the $\mathrm{Nd}$ compositions from metasedimentary sequences in the north and south of the proposed terrane 
boundaries, it is clear that they also present distinct source ages, thus indicating that they represent erosion from different crustal sources. For instance, $\mathrm{T}_{\mathrm{DM}}$ model ages from the Sertânia and the São Caetano complexes in the north are quite similar to the metaplutonic rocks of the Alto Moxotó and Alto Pajeú terranes, respectively. In spite of their maximum $\mathrm{U}-\mathrm{Pb}$ zircon deposition ages, which are also completely different (ca. 2.01 and $0.97 \mathrm{Ga}$, respectively, we highlight that their $\varepsilon \mathrm{Nd}(\mathrm{t})$ values are very similar to those of the adjoining crust (i.e. metaplutonic rocks) indicating that their precursor basins might have been originated in a different momentum of erosion and deposition as previously proposed by several authors (i.e. Santos, 1996; Brito Neves et al., 2000; Rodrigues and Brito Neves, 2008).

\subsubsection{Tectonic implications}

The Borborema Province in NE Brazil is a complex orogenic region, which its origin is still a matter of debate. According to Santos and Medeiros (1999); Brito Neves (2000) and Van Schmus et al., (2011), this province is composed by a series of tectonostratigraphic terranes that were assembled in Neoproterozoic subduction scenarios. Neves (2015) challenged this model, suggesting that the province corresponds to an intracontinental orogen. Both models are supported by structural and geochronological studies.

The distribution of our $\mathrm{Nd}$ data in an area of good exposure of the Alto Moxotó and Alto Pajeú terranes suggest that these blocks correspond to two distinct litospheric fragments and further support the accretionary model, in which subduction took place during Cariris Velhos orogeny (ca. 1025-900 Ma), being further accreted to southern domains and São Francisco Craton during the Brasiliano-related orogenesis (ca. 800$600 \mathrm{Ma}$ ) as previously suggested by Kozuch, 2003; Santos et al., 2010; Santos et al., 2016, in revision, among others (Figure 6.8). In spite of some scattering, our gridded $\mathrm{T}_{\mathrm{DM}}$ map is nearly coincident with the proposed terrane boundary and combined with available geochronological $\mathrm{U}-\mathrm{Pb}$ data indicate that the Serra do Jabitacá shear zone might represent a cryptic suture zone obliterated by late Brasiliano tectonics. Moreover, our study shows that the Alto Moxotó Terrane is an example of reworked ArcheanPaleoproterozoic crust, with major growth episodes recorded at 2.6 and 2.1-2.0 Ga, whereas the Alto Pajeú Terrane is a typical Neoproterozoic domain with much younger 
isotopic reservoirs. Structural and geophysical evidence also demonstrate that accretion tectonics must played a crucial role on the evolution and assembly of the South American Neoproterozoic belts, including the Borborema Province and West Gondwana (Meert and Lieberman, 2008 and references therein).

Despite that this methodology has been applied in other areas of the Borborema Province, presenting similar results (e.g. Rodrigues and Brito Neves, 2008; Lages et al., 2010), more geochronological and isotopic data must be accessed, in addition to geophysical evidence, including magnetometry, gravity and seismic data, that increasingly demonstrated the role of shear zones on the amalgamation of crustal blocks in Neoproterozoic (Oliveira, 2008; 2010; Correa et al., 2014; Lima et al., 2015; Padilha et al., 2016). Some of them present features that are attributed to suture zones, such as the Transbrasiliano-Kandhi, Patos-Gamoua and Pernambuco-Adamoua lineaments (Brito Neves et al., 2000, 2014; Cordani et al., 2013; Araújo, 2015; Santos et al., 2016, in review). The interpretation of Neoproterozoic assembly of distinct crustal blocks is also reinforced by the widespread distribution of Neoproterozoic magmatic arcs (Lages and Dantas, 2016; Brito Neves et al., 2016, in revision) in the Transversal Sub Province and preserved ophiolitic sequences in the southern Sub Province (Caxito et al., 2014).

Terrane assembly during the amalgamation of West Gondwana is mostly described in the outer portions of it (Casquet et al., 2012). However, the recognition of island arc-related association, disrupted ophiolitic complexes and collision zones in inner belts of West Gondwana, specially in south-central and West Africa can also provide unequivocal insights of accretionary process in the inner portions this continent. For instance, several displaced terranes of distinct geological histories are recognized in the Damara orogen, Tuareg Shield and Trans-Sahara belt, recording a long-lived history of Neoproterozoic terrane assembly (Oliver et al., 1998; Johnson and Oliver, 2000; Gascombe et al., 2000). Despite that the origin of the studied terranes needs further investigation, some Archean and Paleoproterozoic crustal segments of the São Francisco and Congo Cratons, including the Itabuna-Salvador-Curaçá belt and adjacent blocks share similarities in their evolutions with the Alto Moxotó Terrane (eg. Teixeira et al., 2000; Barbosa and Sabaté, 2004 and references therein). The reworking of Archean rocks by Paleoproterozoic subduction-related events observed in the aforementioned cratons, being collectively known as Eburnean orogeny in Congo Craton and adjacent fold belts (Feybesse et al., 2006; Lompo, 2009; Hein, 2010; 
Baratoux et al., 2011) are coeval with metagranitic rocks described throughout the Alto Moxotó Terrane, thus, indicating a possible crustal connection. We suggest that the contrasting isotopic signature observed in our study area is suggestive of terrane collage in this portion of West Gondwana at all.

a) AMT-APT collage during the Cariris Velhos orogenic stage (1000 - $920 \mathrm{Ma}$ )

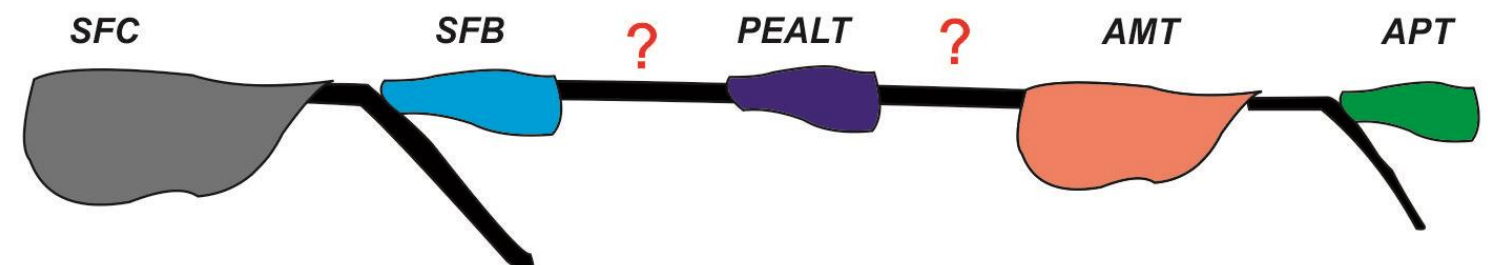

b) Development of subducrion zones during the Brasiliano orogeny (800-650 Ma)

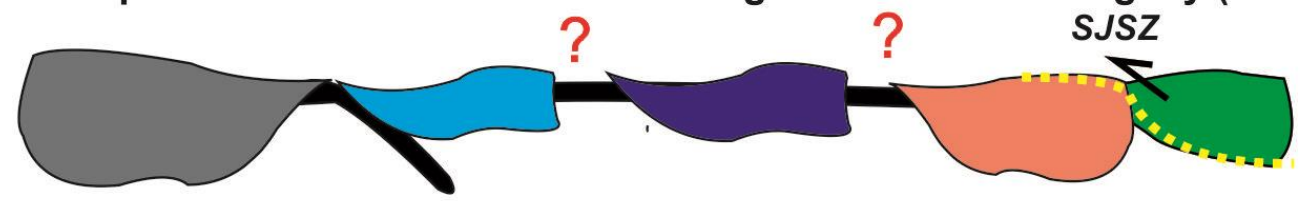

C) Final stage of terrane assembly and accretion to continental margin (650-540 Ma)

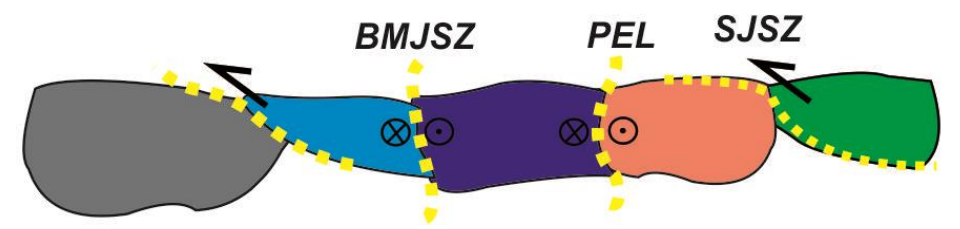

Figure 6.8. Proposed tectonic model for the assembly of the studied terranes and their role on the subsequential evolution of the Borborema Province. SFC = São Francisco Craton, $\mathrm{SFB}=$ Sergipano Fold Belt, PEALT $=$ Pernambuco-Alagoas Terrane, $\mathrm{AMT}=$ Alto Moxotó Terrane, APT $=$ Alto Pajeú Terrane, BMJSZ $=$ Belo Monte Jeremoabo Shear Zone, PEL = Pernambuco Lineament and SJSZ = Serra de Jabitacá Shear Zone. The thick dashed yellow lines marks the main terrane boundaries (suture zones?).

\subsection{Conclusions}

Sm-Nd method aplied as an isotopic tracer on metaplutonic and metasedimentary rocks of the Alto Moxotó and Alto Pajeú terranes of the Borborema Province, reveals a complex tectonic scenario for this part of West Gondwana. One 
hundered and six (106) samples were analized and revealed that these crustal blocks were derived by distinct isotopic reservoirs. The former is characterized by very old $\mathrm{T}_{\mathrm{DM}}$ model ages, that ranges from the Paleoarchean to Early Paleoproterozoice, whereas the other present younger ages, characterizing thus Late-Paleoproterozoic and Mesoproterozoic sources. Such contrasting source ages is more evident if related to the proposed terrane boundary (i.e. Serra de Jabitacá Shear Zone).

Further, calculated $[\varepsilon \mathrm{Nd}(\mathrm{t})]$ parameter using well known U-Pb zircon ages also provided contrasting crust formation and reworking records. Slightly negative to positive values suggest Alto Moxotó terrane was built-up by Neoarchean crustal growth, forming TTG rocks at $2.6 \mathrm{Ga}$. A major event of crustal reworking is at around 2.1-2.0 Ga, which presents a heterogeneous distribution of sources, including juvenile inputs. Lastly, a last event is dated at $1.6 \mathrm{Ga}$, which is entirely dominated by crustal characteristics. However, in the Alto Pajeú terrane, the analyzed samples are mostly Tonian in age, being related to the Cariris Velhos orogeny (1025-900 Ma), which is absent in the Alto Moxotó Terrane. They are interpreted as the result of crustal reworking of a Paleo-mesoproterozoic source, with limited contributions from the depleted mantle.

\subsection{Acknowledgements}

This paper is the outcome of the first author $\mathrm{PhD}$ thesis at Universidade de Brasília, Brazil. Authors are thankful to Universidade de Brasília geochronology lab staff. Elton Luiz Dantas and Reinhardt Adolfo Fuck acknowledge CNPq financial support through INCT Estudos Tectônicos and research fellowships. 


\begin{tabular}{|c|c|c|c|c|c|c|c|c|c|c|}
\hline Sample & Unit & Lithology & $\begin{array}{l}\mathrm{U}-\mathrm{Pb} \\
\text { age (Ga) }\end{array}$ & $\mathrm{Sm}(\mathrm{ppm})$ & $\begin{array}{l}\mathrm{Nd} \\
(\mathrm{ppm})\end{array}$ & ${ }^{147} \mathrm{Sm} /{ }^{144} \mathrm{Nd}$ & $\begin{array}{l}{ }^{143} \mathrm{Nd} /{ }^{144} \mathrm{Nd} \\
( \pm 2 \mathrm{SE})\end{array}$ & $\varepsilon N d(0)$ & $\varepsilon N d(t)$ & $\begin{array}{l}\mathrm{T}_{\mathrm{DM}} \\
(\mathrm{Ga})\end{array}$ \\
\hline FL35B & São Pedro Suite & Metagranodiorite & 0.92 & 3.72 & 20.13 & 0.11 & $0.511937( \pm 7)$ & -13.68 & -3.62 & 1.64 \\
\hline FL92 & São Pedro Suite & Metagranodiorite & 0.92 & 5.74 & 40.33 & 0.08 & $0.511558( \pm 12)$ & -21.07 & -7.99 & 1.76 \\
\hline FL78A & São Pedro Suite & Metagranodiorite & 0.92 & 3.87 & 29.50 & 0.07 & $0.511470( \pm 24)$ & -22.78 & -8.91 & 1.77 \\
\hline FL78B & São Pedro Suite & Metamonzogranite & 0.92 & 0.35 & 2.19 & 0.08 & $0.511657( \pm 23)$ & -19.13 & -7.19 & 1.78 \\
\hline FL80A & São Pedro Suite & Metagranodiorite & 0.92 & 4.10 & 27.13 & 0.09 & $0.511554( \pm 2)$ & -21.15 & -8.67 & 1.84 \\
\hline FL89 & São Pedro Suite & Metatonalite & 0.92 & 2.91 & 20.15 & 0.08 & $0.511502( \pm 8)$ & -22.16 & -9.23 & 1.85 \\
\hline FL79A & São Pedro Suite & Metatonalite & 0.92 & 2.89 & 19.47 & 0.09 & $0.511524( \pm 10)$ & -21.74 & -9.09 & 1.86 \\
\hline FL91 & São Pedro Suite & Metatonalite & 0.92 & 3.59 & 24.33 & 0.09 & $0.511507( \pm 7)$ & -22.05 & -9.36 & 1.87 \\
\hline FL80B & São Pedro Suite & Metagrabodiorite & 0.92 & 4.83 & 32.91 & 0.09 & $0.511485( \pm 8)$ & -22.49 & -9.74 & 1.89 \\
\hline FL90 & São Pedro Suite & Metamonzogranite & 0.92 & 4.19 & 28.30 & 0.09 & $0.511471( \pm 13)$ & -22.79 & -10.08 & 1.91 \\
\hline SP4 & São Pedro Suite & Metamonzogranite & 0.92 & 2.37 & 15.09 & 0.10 & $0.511479( \pm 11)$ & -22.61 & -10.59 & 1.99 \\
\hline SP3 & São Pedro Suite & Metamonzogranite & 0.92 & 2.08 & 12.55 & 0.10 & $0.511508( \pm 19)$ & -22.04 & -10.63 & 2.05 \\
\hline SPP3 & $\begin{array}{l}\text { Serrote das Pedras } \\
\text { Pretas Suite }\end{array}$ & Hornblendite & 1.02 & 2.46 & 14.43 & 0.10 & $0.511857( \pm 10)$ & -15.23 & -2.98 & 1.62 \\
\hline SPP1 & $\begin{array}{l}\text { Serrote das Pedras } \\
\text { Pretas Suite }\end{array}$ & Metagabbro & 1.02 & 2.73 & 15.75 & 0.10 & $0.511863( \pm 18)$ & -15.11 & -3.05 & 1.64 \\
\hline
\end{tabular}




\begin{tabular}{|c|c|c|c|c|c|c|c|c|c|c|}
\hline SPP2 & $\begin{array}{l}\text { Serrote das Pedras } \\
\text { Pretas Suite }\end{array}$ & Metagabbro & 1.02 & 4.49 & 18.00 & 0.15 & $0.512339( \pm 9)$ & -5.83 & +0.20 & 1.68 \\
\hline FL55 & $\begin{array}{l}\text { Serrote das Pedras } \\
\text { Pretas Suite }\end{array}$ & Metapyroxenite & 1.02 & 2.50 & 17.80 & 0.10 & $0.511632( \pm 16)$ & -19.63 & -7.26 & 1.92 \\
\hline FL90 & $\begin{array}{l}\text { Serrote das Pedras } \\
\text { Pretas Suite }\end{array}$ & Metagabbro & 1.02 & 4.19 & 28.30 & 0.09 & $0.511471( \pm 13)$ & -22.79 & -8.72 & 1.91 \\
\hline FL84A & $\begin{array}{l}\text { São Caetano } \\
\text { Complex }\end{array}$ & $\begin{array}{l}\text { Muscovite } \\
\text { paragneiss }\end{array}$ & 0.97 & 3.66 & 13.75 & 0.16 & $0.512565( \pm 15)$ & -1.42 & - & 1.36 \\
\hline FL36 & $\begin{array}{l}\text { São Caetano } \\
\text { Complex }\end{array}$ & $\begin{array}{l}\text { Biotite-muscovite } \\
\text { paragneiss }\end{array}$ & 0.97 & 6.69 & 35.60 & 0.11 & $0.512134( \pm 24)$ & -9.84 & - & 1.37 \\
\hline FL162 & $\begin{array}{l}\text { São Caetano } \\
\text { Complex }\end{array}$ & Muscovite schist & 0.97 & 6.06 & 32.81 & 0.11 & $0.512091( \pm 12)$ & -10.66 & - & 1.41 \\
\hline FL97 & $\begin{array}{l}\text { São Caetano } \\
\text { Complex }\end{array}$ & $\begin{array}{l}\text { Biotite-muscovite } \\
\text { schist }\end{array}$ & 0.97 & 2.15 & 12.12 & 0.11 & $0.512009( \pm 26)$ & -12.27 & - & 1.47 \\
\hline FL161 & $\begin{array}{l}\text { São Caetano } \\
\text { Complex }\end{array}$ & Altered basalt & 0.97 & 8.42 & 45.47 & 0.11 & $0.512051( \pm 22)$ & -11.46 & - & 1.48 \\
\hline FL37 & $\begin{array}{l}\text { São Caetano } \\
\text { Complex }\end{array}$ & Altered basalt & 0.97 & 8.77 & 43.69 & 0.12 & $0.512081( \pm 14)$ & -10.87 & - & 1.57 \\
\hline FL159 & $\begin{array}{l}\text { São Caetano } \\
\text { Complex }\end{array}$ & $\begin{array}{l}\text { Altered } \\
\text { pyroclastic rock }\end{array}$ & 0.97 & 6.19 & 38.20 & 0.10 & $0.511841( \pm 35)$ & -15.55 & - & 1.57 \\
\hline FL96 & São Caetano & Muscovite & 0.97 & 2.15 & 12.12 & 0.12 & $0.512009( \pm 26)$ & -12.27 & - & 1.61 \\
\hline
\end{tabular}




\begin{tabular}{|c|c|c|c|c|c|c|c|c|c|c|}
\hline & Complex & paragneiss & & & & & & & & \\
\hline FL166 & $\begin{array}{l}\text { São Caetano } \\
\text { Complex }\end{array}$ & $\begin{array}{l}\text { Muscovite } \\
\text { paragneiss }\end{array}$ & 0.97 & 5.96 & 28.75 & 0.12 & $0.512092( \pm 15)$ & -10.65 & - & 1.62 \\
\hline FL48 & $\begin{array}{l}\text { São Caetano } \\
\text { Complex }\end{array}$ & $\begin{array}{l}\text { Muscovite } \\
\text { paragneiss }\end{array}$ & 0.97 & 2.34 & 11.15 & 0.12 & $0.512089( \pm 21)$ & -10.72 & - & 1.66 \\
\hline FL126G & $\begin{array}{l}\text { São Caetano } \\
\text { Complex }\end{array}$ & $\begin{array}{l}\text { Muscovite } \\
\text { paragneiss }\end{array}$ & 0.97 & 4.24 & 35.33 & 0.07 & $0.511473( \pm 17)$ & -22.72 & - & 1.68 \\
\hline FL167 & $\begin{array}{l}\text { São Caetano } \\
\text { Complex }\end{array}$ & $\begin{array}{l}\text { Muscovite } \\
\text { paragneiss }\end{array}$ & 0.97 & 8.04 & 43.97 & 0.11 & $0.511871( \pm 14)$ & -14.96 & - & 1.72 \\
\hline FL160 & $\begin{array}{l}\text { São Caetano } \\
\text { Complex }\end{array}$ & Muscovite schist & 0.97 & 7.44 & 39.90 & 0.11 & $0.511888( \pm 15)$ & -14.63 & - & 1.73 \\
\hline FL49 & $\begin{array}{l}\text { São Caetano } \\
\text { Complex }\end{array}$ & $\begin{array}{l}\text { Biotite-muscovite } \\
\text { schist }\end{array}$ & 0.97 & 3.87 & 18.50 & 0.13 & $0.512045( \pm 38)$ & -11.56 & - & 1.73 \\
\hline FL164 & $\begin{array}{l}\text { São Caetano } \\
\text { Complex }\end{array}$ & $\begin{array}{l}\text { Biotite-muscovite } \\
\text { paragneiss }\end{array}$ & 0.97 & 5.81 & 28.82 & 0.12 & $0.51198( \pm 7)$ & -12.83 & - & 1.75 \\
\hline FL163 & $\begin{array}{l}\text { São Caetano } \\
\text { Complex }\end{array}$ & $\begin{array}{l}\text { Biotite-muscovite } \\
\text { paragneiss }\end{array}$ & 0.97 & 6.45 & 32.02 & 0.12 & $0.511974( \pm 13)$ & -12.95 & - & 1.76 \\
\hline FL168 & $\begin{array}{l}\text { São Caetano } \\
\text { Complex }\end{array}$ & $\begin{array}{l}\text { Biotite-muscovite } \\
\text { paragneiss }\end{array}$ & 0.97 & 8.43 & 45.32 & 0.11 & $0.511843( \pm 17)$ & -15.5 & - & 1.79 \\
\hline FL85 & $\begin{array}{l}\text { São Caetano } \\
\text { Complex }\end{array}$ & $\begin{array}{l}\text { Biotite-muscovite } \\
\text { schist }\end{array}$ & 0.97 & 3.49 & 18.50 & 0.11 & $0.511844( \pm 15)$ & -15.48 & - & 1.82 \\
\hline
\end{tabular}




$\begin{array}{llllllllll}\text { FL84B } & \begin{array}{l}\text { São Caetano } \\ \text { Complex }\end{array} & \begin{array}{l}\text { Biotite-muscovite } \\ \text { schist }\end{array} & 0.97 & 4.37 & 16.16 & 0.16 & 0.512424( \pm 21) & -4.17 & - \\ \text { FL38 } & \begin{array}{l}\text { São Caetano } \\ \text { Complex }\end{array} & \begin{array}{l}\text { Muscovite } \\ \text { paragneiss }\end{array} & 0.97 & 3.53 & 16.52 & 0.13 & 0.511947( \pm 19) & -13.48 & -\end{array}$

Table 6.1 - Summary of $\mathrm{Nd}$ isotope data for the metaplutonic and metassedinemtary rocks of the Alto Pajeú Terrane. U-Pb zircon ages was extracted from Santos (1995); Guimarães et al. (2012) and Lages and Dantas (2016). 


\begin{tabular}{|c|c|c|c|c|c|c|c|c|c|c|}
\hline Sample & Unit & Lithology & $\mathrm{U}-\mathrm{Pb}$ age $(\mathrm{Ga})$ & $\mathrm{Sm}(\mathrm{ppm})$ & $\mathrm{Nd}(\mathrm{ppm})$ & ${ }^{147} \mathrm{Sm} /{ }^{144} \mathrm{Nd}$ & ${ }^{143} \mathrm{Nd} /{ }^{144} \mathrm{Nd}( \pm 2 \mathrm{SE})$ & $\varepsilon N d(0)$ & $\varepsilon N d(t)$ & $\mathrm{T}_{\mathrm{DM}}(\mathrm{Ga})$ \\
\hline FL46A & $\begin{array}{l}\text { Riacho das } \\
\text { Lajes Suite }\end{array}$ & Metagranodiorite & 2.62 & 2.38 & 19.88 & 0.07 & $0.510477( \pm 19)$ & -41.41 & +2.35 & 2.90 \\
\hline FL53 & $\begin{array}{l}\text { Riacho das } \\
\text { Lajes Suite }\end{array}$ & Metagranodiorite & 2.62 & 4.50 & 33.54 & 0.08 & $0.510637( \pm 20)$ & -39.03 & +0.01 & 2.76 \\
\hline FL83 & $\begin{array}{l}\text { Riacho das } \\
\text { Lajes Suite }\end{array}$ & Metatonalite & 2.62 & 2.04 & 9.43 & 0.13 & $0.511544( \pm 8)$ & -41.27 & -0.61 & 2.79 \\
\hline FL56 & $\begin{array}{l}\text { Riacho das } \\
\text { Lajes Suite }\end{array}$ & Metatonalite & 2.62 & 1.88 & 16.01 & 0.07 & $0.51043( \pm 12)$ & -42.15 & +0.14 & 2.76 \\
\hline FL58 & $\begin{array}{l}\text { Riacho das } \\
\text { Lajes Suite }\end{array}$ & Metatonalite & 2.62 & 2.92 & 23.15 & 0.08 & $0.510522( \pm 14)$ & -43.07 & +0.58 & 2.78 \\
\hline FL57 & $\begin{array}{l}\text { Riacho das } \\
\text { Lajes Suite }\end{array}$ & Metatonalite & 2.62 & 2.36 & 17.26 & 0.08 & $0.510587( \pm 9)$ & -40.01 & +1.44 & 2.85 \\
\hline FL105 & $\begin{array}{l}\text { Riacho das } \\
\text { Lajes Suite }\end{array}$ & $\begin{array}{l}\text { Granodioritic } \\
\text { orthogneiss }\end{array}$ & 2.62 & 2.28 & 17.07 & 0.08 & $0.510515( \pm 17)$ & -34.60 & +2.09 & 2.93 \\
\hline FL54B & $\begin{array}{l}\text { Riacho das } \\
\text { Lajes Suite }\end{array}$ & $\begin{array}{l}\text { Granodioritic } \\
\text { orthogneiss }\end{array}$ & 2.62 & 2.02 & 12.16 & 0.10 & $0.510864( \pm 5)$ & -21.34 & +0.92 & 2.76 \\
\hline FL65 & $\begin{array}{l}\text { Floresta } \\
\text { Suite }\end{array}$ & Metadiorite & 2.10 & 3.48 & 21.57 & 0.09 & $0.511583( \pm 20)$ & -20.57 & +6.19 & 1.90 \\
\hline FL95B & $\begin{array}{l}\text { Floresta } \\
\text { Suite }\end{array}$ & Metatonalite & 2.10 & 1.93 & 9.16 & 0.12 & $0.511897( \pm 3)$ & -14.45 & +4.24 & 2.01 \\
\hline
\end{tabular}




\begin{tabular}{|c|c|c|c|c|c|c|c|c|c|c|}
\hline FL88 & $\begin{array}{l}\text { Floresta } \\
\text { Suite }\end{array}$ & Metagranodiorite & 2.10 & 0.54 & 3.02 & 0.11 & $0.511660( \pm 10)$ & -19.08 & +4.47 & 2.01 \\
\hline FL86 & $\begin{array}{l}\text { Floresta } \\
\text { Suite }\end{array}$ & Metatonalite & 2.10 & 12.14 & 57.58 & 0.13 & $0.511811( \pm 16)$ & -16.15 & +2.51 & 2.17 \\
\hline FL70 & $\begin{array}{l}\text { Floresta } \\
\text { Suite }\end{array}$ & $\begin{array}{l}\text { Granodioritic } \\
\text { orthogneiss }\end{array}$ & 2.10 & 1.56 & 12.07 & 0.08 & $0.511049( \pm 18)$ & -30.99 & $0+.94$ & 2.23 \\
\hline FL126B & $\begin{array}{l}\text { Floresta } \\
\text { Suite }\end{array}$ & $\begin{array}{l}\text { Tonalitic } \\
\text { orthogneiss }\end{array}$ & 2.10 & 11.51 & 63.62 & 0.11 & $0.511479( \pm 19)$ & -22.61 & +0.92 & 2.27 \\
\hline FL68 & $\begin{array}{l}\text { Floresta } \\
\text { Suite }\end{array}$ & $\begin{array}{l}\text { Granodioritic } \\
\text { orthogneiss }\end{array}$ & 2.10 & 2.72 & 19.43 & 0.08 & $0.511112( \pm 18)$ & -29.77 & +0.44 & 2.27 \\
\hline FL62 & $\begin{array}{l}\text { Floresta } \\
\text { Suite }\end{array}$ & $\begin{array}{l}\text { Granodioritic } \\
\text { orthogneiss }\end{array}$ & 2.10 & 8.97 & 47.45 & 0.11 & $0.511552( \pm 14)$ & -21.19 & +1.05 & 2.27 \\
\hline FL73 & $\begin{array}{l}\text { Floresta } \\
\text { Suite }\end{array}$ & Metamonzogranite & 2.10 & 4.88 & 25.18 & 0.12 & $0.511588( \pm 15)$ & -20.49 & +0.92 & 2.29 \\
\hline FL67 & $\begin{array}{l}\text { Floresta } \\
\text { Suite }\end{array}$ & Metamonzogranite & 2.10 & 7.85 & 35.44 & 0.13 & $0.511818( \pm 18)$ & -16.00 & +0.91 & 2.33 \\
\hline FL126C & $\begin{array}{l}\text { Floresta } \\
\text { Suite }\end{array}$ & Metamonzogranite & 2.10 & 7.58 & 39.94 & 0.11 & $0.511512( \pm 9)$ & -21.97 & +0.11 & 2.35 \\
\hline FL126E & $\begin{array}{l}\text { Floresta } \\
\text { Suite }\end{array}$ & Metamonzogranite & 2.10 & 7.57 & 40.92 & 0.11 & $0.511451( \pm 12)$ & -23.15 & -0.27 & 2.37 \\
\hline FL60 & Floresta & Metatonalite & 2.10 & 4.76 & 26.70 & 0.11 & $0.511388( \pm 5)$ & -24.39 & -0.45 & 2.37 \\
\hline
\end{tabular}


Suite

\begin{tabular}{|c|c|c|c|c|c|c|c|c|c|c|}
\hline FL69 & $\begin{array}{l}\text { Floresta } \\
\text { Suite }\end{array}$ & $\begin{array}{l}\text { Monzogranitic } \\
\text { orthogneiss }\end{array}$ & 2.10 & 3.48 & 17.72 & 0.12 & $0.511553( \pm 13)$ & -21.16 & -0.17 & 2.38 \\
\hline FL126F & $\begin{array}{l}\text { Floresta } \\
\text { Suite }\end{array}$ & $\begin{array}{l}\text { Monzonitic } \\
\text { orthogneiss }\end{array}$ & 2.10 & 8.69 & 46.50 & 0.11 & $0.511447( \pm 5)$ & -23.23 & -0.70 & 2.41 \\
\hline FL126A & $\begin{array}{l}\text { Floresta } \\
\text { Suite }\end{array}$ & $\begin{array}{l}\text { Granodioritic } \\
\text { orthogneiss }\end{array}$ & 2.10 & 3.73 & 21.50 & 0.10 & $0.511295( \pm 22)$ & -26.20 & -1.51 & 2.44 \\
\hline FL64 & $\begin{array}{l}\text { Floresta } \\
\text { Suite }\end{array}$ & $\begin{array}{l}\text { Granodioritic } \\
\text { orthogneiss }\end{array}$ & 2.10 & 3.74 & 18.16 & 0.12 & $0.511590( \pm 8)$ & -20.44 & -0.99 & 2.48 \\
\hline FL40 & $\begin{array}{l}\text { Floresta } \\
\text { Suite }\end{array}$ & Metadiorite & 2.10 & 2.84 & 17.04 & 0.10 & $0.511191( \pm 8)$ & -28.23 & -2.42 & 2.49 \\
\hline FL35A & $\begin{array}{l}\text { Floresta } \\
\text { Suite }\end{array}$ & Metatonalite & 2.10 & 2.03 & 9.07 & 0.13 & $0.511747( \pm 16)$ & -17.39 & -0.75 & 2.50 \\
\hline FL126D & $\begin{array}{l}\text { Floresta } \\
\text { Suite }\end{array}$ & Metagranodiorite & 2.10 & 7.57 & 38.51 & 0.12 & $0.511480( \pm 12)$ & -22.59 & -1.60 & 2.50 \\
\hline FL32A & $\begin{array}{l}\text { Floresta } \\
\text { Suite }\end{array}$ & Metadiorite & 2.10 & 10.05 & 76.46 & 0.08 & $0.510751( \pm 4)$ & -36.81 & -5.25 & 2.60 \\
\hline FL102 & $\begin{array}{l}\text { Floresta } \\
\text { Suite }\end{array}$ & Metadiorite & 2.10 & 10.05 & 80.02 & 0.07 & $0.510671( \pm 19$ & -38.37 & -5.85 & 2.62 \\
\hline FL104A & $\begin{array}{l}\text { Floresta } \\
\text { Suite }\end{array}$ & Metagranodiorite & 2.10 & 1.34 & 10.27 & 0.08 & $0.510631( \pm 25)$ & -39.15 & -7.36 & 2.72 \\
\hline
\end{tabular}




\begin{tabular}{|c|c|c|c|c|c|c|c|c|c|c|}
\hline FL106A & $\begin{array}{l}\text { Floresta } \\
\text { Suite }\end{array}$ & Metagranodiorite & 2.10 & 4.09 & 18.53 & 0.14 & $0.511547( \pm 17)$ & -21.28 & -4.32 & 2.86 \\
\hline FL59 & $\begin{array}{l}\text { Floresta } \\
\text { Suite }\end{array}$ & Metatonalite & 2.10 & 2.69 & 18.86 & 0.09 & $0.510594( \pm 16)$ & -39.87 & -10.17 & 2.93 \\
\hline FL66 & $\begin{array}{l}\text { Floresta } \\
\text { Suite }\end{array}$ & Metamonzogranite & 2.10 & 11.83 & 69.88 & 0.10 & $0.510722( \pm 19)$ & -37.37 & -12.02 & 3.19 \\
\hline FL63 & $\begin{array}{l}\text { Malhada } \\
\text { Vermelha } \\
\text { Suite }\end{array}$ & Metagabbro & 2.15 & 1.99 & 9.86 & 0.12 & $0.511660( \pm 11)$ & -19.07 & +1.46 & 2.29 \\
\hline MV5 & $\begin{array}{l}\text { Malhada } \\
\text { Vermelha } \\
\text { Suite }\end{array}$ & Leucometagabbro & 2.15 & 0.71 & 2.97 & 0.15 & $0.511955( \pm 10)$ & -13.32 & +0.78 & 2.43 \\
\hline MV4 & $\begin{array}{l}\text { Malhada } \\
\text { Vermelha } \\
\text { Suite }\end{array}$ & $\begin{array}{l}\text { Garnet } \\
\text { metagabbro }\end{array}$ & 2.15 & 0.72 & 2.89 & 0.15 & $0.511929( \pm 18)$ & -13.83 & -1.25 & 2.72 \\
\hline FL104C & $\begin{array}{l}\text { Malhada } \\
\text { Vermelha } \\
\text { Suite }\end{array}$ & $\begin{array}{l}\text { Garnet } \\
\text { metagabbro }\end{array}$ & 2.15 & 2.87 & 23.10 & 0.07 & $0.510404( \pm 7)$ & -43.58 & -10.0 & 2.90 \\
\hline MV3 & $\begin{array}{l}\text { Malhada } \\
\text { Vermelha }\end{array}$ & & & & & 0.14 & & & & \\
\hline FL124 & $\begin{array}{l}\text { Suite } \\
\text { Riacho do } \\
\text { Navio }\end{array}$ & $\begin{array}{l}\text { Metagabbro } \\
\text { Biotite augen }\end{array}$ & $\begin{array}{l}2.15 \\
1.61\end{array}$ & $\begin{array}{l}0.45 \\
4.47\end{array}$ & $\begin{array}{l}1.94 \\
24.08\end{array}$ & 0.11 & $\begin{array}{l}0.511458( \pm 61) \\
0.511571( \pm 11)\end{array}$ & $\begin{array}{l}-23.02 \\
-20.81\end{array}$ & $\begin{array}{l}-7.56 \\
-3.39\end{array}$ & 3.34 \\
\hline
\end{tabular}




\begin{tabular}{|c|c|c|c|c|c|c|c|c|c|c|}
\hline & Suite & gneiss & & & & & & & & \\
\hline FL100 & $\begin{array}{l}\text { Riacho do } \\
\text { Navio } \\
\text { Suite }\end{array}$ & Metamonzogranite & 1.61 & 3.44 & 21.24 & 0.10 & $0.511233( \pm 14)$ & -27.40 & -7.00 & 2.37 \\
\hline FL117 & $\begin{array}{l}\text { Riacho do } \\
\text { Navio } \\
\text { Suite }\end{array}$ & Metasyenogranite & 1.61 & 2.51 & 12.89 & 0.12 & $0.511533( \pm 6)$ & -21.56 & -5.21 & 2.38 \\
\hline FL25 & $\begin{array}{l}\text { Riacho do } \\
\text { Navio } \\
\text { Suite }\end{array}$ & Metasyenogranite & 1.61 & 4.46 & 26.57 & 0.10 & $0.511279( \pm 15)$ & -26.51 & -6.87 & 2.39 \\
\hline FL101 & $\begin{array}{l}\text { Riacho do } \\
\text { Navio } \\
\text { Suite }\end{array}$ & $\begin{array}{l}\text { Biotite augen } \\
\text { gneiss }\end{array}$ & 1.61 & 6.18 & 35.17 & 0.11 & $0.511341( \pm 12)$ & -25.3 & -6.65 & 2.41 \\
\hline FL51A & $\begin{array}{l}\text { Riacho do } \\
\text { Navio } \\
\text { Suite }\end{array}$ & $\begin{array}{l}\text { Biotite augen } \\
\text { gneiss }\end{array}$ & 1.61 & 10.34 & 60.90 & 0.10 & $0.511253( \pm 13)$ & -27.02 & -7.60 & 2.45 \\
\hline FL99 & $\begin{array}{l}\text { Riacho do } \\
\text { Navio } \\
\text { Suite }\end{array}$ & Metamonzogranite & 1.61 & 4.54 & 25.97 & 0.10 & $0.511325( \pm 10)$ & -25.61 & -6.89 & 2.42 \\
\hline FL125 & $\begin{array}{l}\text { Riacho do } \\
\text { Navio } \\
\text { Suite }\end{array}$ & Metamonzogranite & 1.61 & 10.84 & 54.52 & 0.12 & $0.511484( \pm 5)$ & -22.51 & -6.73 & 2.54 \\
\hline
\end{tabular}


Riacho do

FL95A Navio

Suite

Metamonzogranite 1.61

Riacho do

FL120A Navio

Suite

Mylonitic gneiss

1.61

Riacho do

FL123 Navio

Suite

Biotite augen

gneiss

1.61

Riacho do

FL119 Navio

Suite

Metasyenogranite

1.61

Riacho do

FL122 Navio

Suite

Metasyenogranite 1.61

FL44 Sertânia Garnet-biotite

Complex paragneiss $\quad 2.01$

FL70B Sertânia Garnet-biotite

Complex paragneiss

2.01

Sertânia Garnet-biotite

Complex

paragneiss

2.01

FL43

Sertânia

Migmatized

garnet-biotite
6.61

36.76

4.51

30.41

$3.47 \quad 29.21$

4.20

24.59

$5.60 \quad 35.15$
0.11

$$
0.511277( \pm 17) \quad-26.56
$$

$-8.42 \quad 2.56$

0.09

$0.510933( \pm 13) \quad-33.25$

$-11.18 \quad 2.58$

0.07

$0.510579( \pm 13) \quad-40.16$

$-14.44 \quad 2.64$

0.10

$0.510985( \pm 13) \quad-32.24$

$-13.02 \quad 2.84$

0.10

$0.510797( \pm 7) \quad-35.91$

$-15.25 \quad 2.92$

0.16

$0.512367( \pm 29)--5.29$

0.09

$0.511056( \pm 11)$

$-30.85$

2.32

0.12

$0.511549( \pm 7)$

$-21.23$

2.44

$17.34 \quad 115.67$

0.09

$0.510992( \pm 9)$

$-32.1$

2.53 


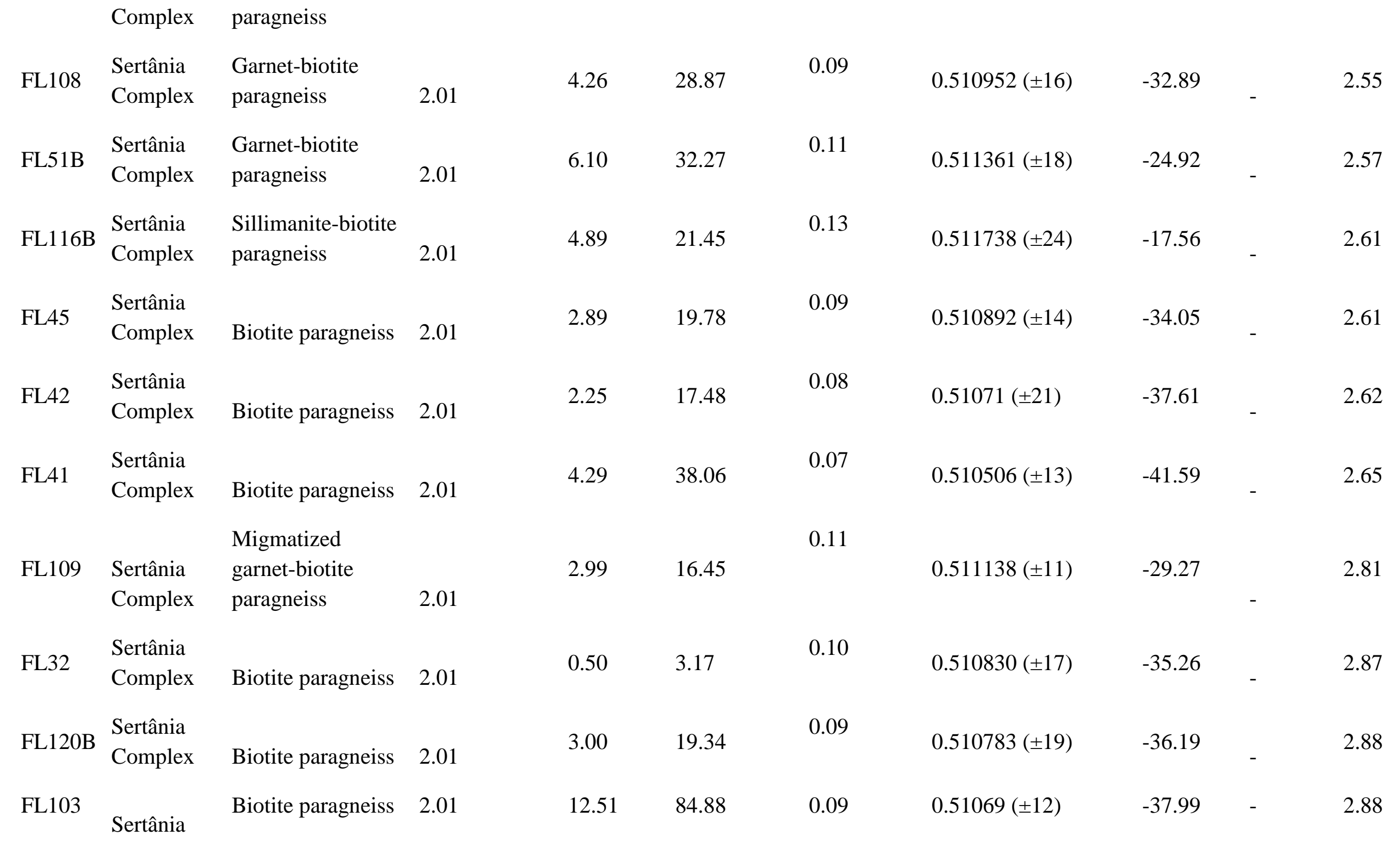


Complex

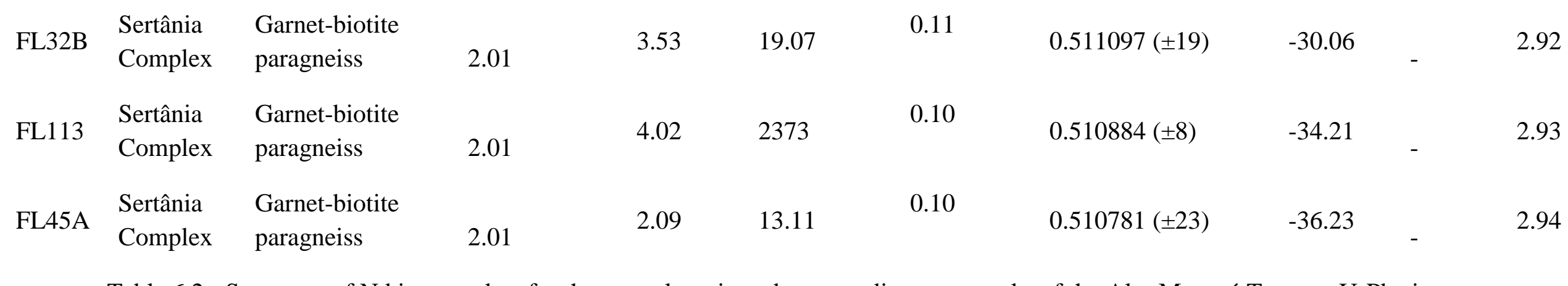

Table 6.2 - Summary of Nd isotope data for the metaplutonic and metassedinemtary rocks of the Alto Moxotó Terrane. U-Pb zircon ages was extracted from Santos (2004) and Santos (2016). 


\subsection{References}

Almeida, F.F.M., Hasui, Y., Brito Neves, B.B., Fuck, R.A., 1981. Brazilian structural provinces: an introduction. Earth Science Reviews 18, 1-29.

Araujo, C.E.G., Rubatto, D., Hermann, J., Cordani, G.U., Caby, R., Basei, M.A.S. 2014. Ediacaran 2,500 km-long synchronous deep continental subduction in the West Gondwana Orogen. Nature Communications 1, 1-8.

Archanjo, C.J., Hollanda, M.H.B.M., Rodrigues, S.W., Brito Neves, B.B., 2008. Fabrics of pre- and syntectonic granite plutons and chronology of shear zones in the Eastern Borborema Province, NE Brazil. Journal of Structural Geology 30, 310-336.

Archanjo, C.J., Hollanda, M.H.B.M., Rodrigues, S.W., Brito Neves, B.B., 2008. Fabrics of pre- and syntectonic granite plutons and chronology of shear zones in the Eastern Borborema Province, NE Brazil. Journal of Structural Geology 30, 310-336.

Arthaud, M.H., Caby, R., Fuck, R.A., Dantas, E.L., Parente, C.V., 2008. Geology of the northern Borborema Province, NE Brazil and its correlation with Nigeria, NW Africa. In: Pankhurst, R.J., Trouw, R.A.J., Brito Neves, B.B., De Wit, M.J. (Eds.), West Gondwana: Pre-Cenozoic correlations across the South Atlantic Region. Geological Society of London Special Publication, 49-67.

Baratoux, L., Metelka, V., Naca, S., Jessel, M.W., Gregoire, M., Ganne, J., 2011. Juvenile Paleoproterozoic crust evolution during the Eburnean orogeny (2.20 - 2.0 Ga), western Burkina Faso. Precambrian Research 191-18-45.

Bennet, V.C., DePaolo, D.J. 1987. Proterozoic crustal history of the western United States ad determined by neodymium isotopic mapping. GSA Bulletim 99, 674-685.

Black R., Liégois, J.P., Latouche L., Caby R., Bertrand J.M. 1994. Pan-African displaced terranes in the Tuareg Shield (Central Sahara). Geology 22, 641-644.

Brito Neves, B.B., 1975. Regionalização Geotectônica Do Précambriano Nordestino (Tese de Doutorado). Universidade de São Paulo, São Paulo, p. 198.

Brito Neves, B.B., Van Schmus, W.R., Santos, E.J., Campos Neto, M.C., Kozuch, M. 1995. O Evento Cariris Velhos na Província Borborema: integração de dados, implicações e perspectivas. Revista Brasileira de Geociências 25, 279-296. 
Brito Neves, B.B., Santos, E.J., Schmus, W.R.Q., 2000. Tectonic history of the Borborema Province. In: Umberto Cordani; Edson José Milani; Antonio Thomaz Filho; Diogenes de Almeida Campos (Org.). Tectonic Evolution of South America. Rio de Janeiro: 31st International Geological Congress, pp. 151-182. Special Publication.

Brito Neves, B.B., Fuck, R.A., Pimentel, M.M. 2014. The Brasiliano collage in South America: a review. Brazilian Journal of Geology 44, 493-518.

Cawood, P.A.; Buchan, C. 2007. Linking accretionary orogenesis with supercontinent assembly. Earth Science Reciews 82, 217-256.

Cawood, P.A.; Kroner, A.; Collins, W.J.; Kusky, T.M.; Mooney, W.D.; Windley, B.F. 2009. Accretionary orogens through earth history. Geological Society London Special Publications 318, 1-36.

Cawood, P. A., Leitch, E.C., Merle, R.E., Nemchin, A.A. 2011. Orogenesis without collision: Stabilizing the Terra Australis accretionary orogen, eastern Australia. Geological Society of America Bulletin 123, 2240-2255.

Casquet, C., Rapela, C.W., Pankhurst, R.J., Baldo, E.G., Galindo, C., Fanning, C.M., Dahlquist, J.A., Saavedra, J. 2012. A history of proterozoic terranes in southern South America: From Rodinia to Gondwana. Geoscience Frontiers 3, 137-145.

Caxito, F., Uhlein, A., Stevenson, R., Uhlein, G.J. 2014. Neoproterozoic oceanic crust remmants in northeast Brazil. Geology 42, 387-390.

Champion, D.C., Cassidy, K.F. 2008. Geodynamics: using geochemistry and isotope signature of granites to aid mineral system studies: an example from the Yilgarn craton: Geoscience Australia Record 2008/2009, 7-17.

Correa, R.T., Vidotti, R.M., Oskum, E. 2016. Curie surface of the Borborema Province, Brazil. Tectonophysics 679, 73-87.

Cordani, E.G., Pimentel, M.M., Aráujo, C.E.G., Fuck, R.A., 2013. The significance of the Transbrasiliano-Kandi tectonic corridor for the amalgamation of West Gondwana. Brazilian Journal of Geology 43, 583-597.

Costa, F.G., Palheta, E.S.M., Rodrigues, J.B., Gomes, I.P.G., Vasconcelos, A.M. 2015. Geochemistry and U-Pb zircon ages of plutonic rocks from the Algodões granite- 
greenstone terrane, Troia Massif, northern Borborema Province, Brazil: Implications for Paleoproterozoic subdiction-accretion processes. Journal of South American Earth Sciences 59, 45-68.

Dantas, E.L., Hackspacher, P.C., Fetter, A.H., Sato, K., Pimentel, M.M., Godoy, A.. 2000. Nd isotope systematics related to proterozoic evolution of the Ribeira Belt in the state of São Paulo, SE Brazil. Revista Brasileira de Geociências 30, 140-143.

Dantas, E.L., Souza, Z.S., Wernick, E., Hackspacher, P.C., Martin, H., Xiadong, D., Li, J.W., 2013. Crustal growth in the 3.4-2.7 Ga São José do Campestre Massif, Borborema Province, NE Brazil. Precambrian Research 227, 12-156.

DePaolo, D.J., Wasserburg, G.J. 1976. Inferences about magma sources and mantle structures from variations on ${ }^{143} \mathrm{Nd} /{ }^{144} \mathrm{Nd}$. Geophysical Research Letters 3, 743-746.

DePaolo, D.J. 1981. A neodymium and strontium isotopic study of the Mesozoic calcalkaline granitic batholiths of the Sierra Nevada and Peninsular Ranges, California. Journal of Geophysical Researcg. 86, 10470-10488.

DePaolo, D.J. 1981. A neodymium and strontium isotopic study of the Mesozoic calcalkaline granitic batholiths of the Sierra Nevada and Peninsular Ranges, California. Journal of Geophysical Researcg. 86, 10470-10488.

Fetter, A.H., Santos, T.J.S., Van Schmus, W.R., Hackhpacher, P.C., Brito Neves, B.B., Arthaud, M.H., Nogueira Neto, J.A., Wernick, E. 2003. Evidence for Neoproterozoic continental arc magmatism in the Santa Quiteria Batholith of Ceará State, NW Borborema Province, NE Brazil: implications for the assembly ofWest Gondwana. Gondwana Research 6, 265-273.

Fetter, A.H., Van Schmus, W.R., dos Santos, T.J.S., Arthaud, M., Nogueira Neto, J., Arthaud, M. 2000. U-Pb and Sm-Nd geochronological constraints on the crustal evolution and basement architecture of Ceara State, NW Borborema Province, NE Brazil: implications for the existence of the Paleoproterozoic supercontinent Atlantica. Revista Brasileira de Geociencias 30, 102-106 (santos ou dos santos?)

Feybesse, J.L., Billa, M., Guerrot, C., Duguey, R., Lescuyr, J.L., Milesi, J.P., Bouchot, V., 2006. The The Paleoproterozoic Ghanian Province: geodynamic model and ore controls, including regional stress modelling. Precambrian Research 149, 149-196. 
Gióia, S.M.C.L., Pimentel, M.M., 2000. The Sm-Nd isotopic method in the geocrhronology laboratory of the University of Brasilia. Anais da academia brasileira de ciências 72, 219-245.

Goscombe, B., Armstrong, R., Barton, J.M. 2000. Geology of the Chewore inlieres, Zimbabwe: constraining the mesoproterozoic to Paleozoic evolution of the Zambezi Belt. Journal of African Earth Sciences 30, 559-627.

Guimarães, I.P., Silva Filho, A.F., Melo, S.C., Macambira, M.B. 2005. Petrogenesis of A-Type Granitoids from the Pajeú-Paraíba Belt, Borborema Province, NE Brazil: Constraints from geochemistry and isotopic composition. Gondwana Research 8, 347362.

Guimarães, I.P., Van Schmus, W.R., Brito Neves, B.B., Bittar, S.M., Silva Filho, A.F., Armstrong, R. 2012. U-Pb zircon ages of orthogneisses and supracrustal rocks of the Cariris Velhos belt: Onset of Neoproterozoic rifting in the Borborema Province, NE Brazil. Precambrian Research 192, 52-77.

Hein, K.A.A., 2010. Succession of structural events in the Goren greenstone belt (Burkina Faso): Implications for West African tectonics. Journal of African Earth Sciences 58, 83-94.

Hollanda, M.H.B.M., Archanjo, C.J., Batista, J.R., Souza, L.C. 2015. Detrital zircon ages and $\mathrm{Nd}$ isotope compositions of the Seridó and Lavras da Mangabeira basins (Borborema Province, NE Brazil): Evidence for exhumation and recycling associated with a major shift in sedimentary provenance. Precambrian Research 258, 186-207.

Howell, D.G. 1995. Principles of Terrane analysis. Chapman \& Hall, 245 pp.

Johnson, S.P., Oliver, G.J.H. 2000. Mesoproterozoic oceanic subduction, island-arc formation and the initiation of back-arc spreading in the Kibaran Belt of central, southern Africa: evidence from ophiolite terrane, Chewore Inliers, northern Zimbabwe. Precambrian Research 103, 125-146.

Kozuch, M., 2003. Isotopic and trace element geochemistry of Early Neoproterozoic gneissic and metavolcanic rocks in the Cariris Velhos Orogen of the Borborema Province, Brazil, and their bearing tectonic setting ( $\mathrm{PhD}$ thesis). Kansas University, Lawrence, p. 199. 
Lages, G.A., Dantas, E.L. 2016. Floresta and Bodocó Mafic-Ultramafic Complexes, western Borborema Province, Brazil: geochemical and isotope constraints for evolution of a Neoproterozoic arc environment and retro-eclogitic hosted Ti-mineralization. Precambrian Research 280, 95-119.

Lages, G.A., Marinho, M.S., Rodrigues, J.B., Medeiros, V.C., Rodrigues, S.W.O., Vieiry, J.F. 2010. Sm-Nd isotopic patterns and new paleoproterozoic nuclei basement on boundary between Alto Pajeú and Alto Moxotó domains, Borborema Province, NE Brazil. In VII South American Symposium on Isotope Geology - VII SSAGI..

Liégeois, J.O., Black, R., Navez, J., Latouche. 1994. Early and late Pan-African orogenies in the assembly of terranes (Tuareg shield, Niger). Precambrian Research 67, $59-88$.

Liégois, J.O., Latouche, L., Boughara, M., Navez, J., Guiraud, M. 2003. The LATEA metacraton (Central Hoggar, Tuareg shield, Algeria): behavioyr of an old passive margin during the Pan-African orogeny. Journal of African Earth Sciences 37, 161-190.

Lima, M.V.A.G., Berrocal, J., Soares, J.E.P., Fuck, R.A. 2015. Deep seismic refraction experiment in northeast Brazil: New constraints for Borborema province evolution. Journal of South American Earth Sciences 58, 335-349.

Lompo, M. 2009. Geodynamic evolution of the 2.25-2.0 Ga Paleoproterozoic magmatic rocks in the Man-Leo Shield of the West African Craton. A model of subsidence of an oceanic plateau. Geological Society of London 323, 231-254.

Meert, J., Liberman, B.S. 2008. The Neoproterozoic assembly of Gondwana and its relationship to the Ediacaran-Cambrian radiation. Gondwana Research 14, 5-21.

Neves, S.P., Lages, G.A., Brasilino, R.G., Miranda, A.W.A., 2015. Paleoproterozoic accretionary and collisional processes and the build-up of the Borborema Province (NE Brazil): Geochronological and geochemical evidence from the Central Domain. Journal of South American Earth Sciences 58, 165-187.

Oliver, G.J.H., Johnson, S.P., Williams, I.S., Herd, D.A. 1998. Relict of 1.4 Ga oceanic crust in the Zambezi Valley, northern Zimbabwe: Evidence for Mesoproterozoic supercontinent fragmentation. Geology 26, 571-573. 
Oliveira, E.P., Windley, B.F., Araújo, M.N.C. 2010. The Neoproterozoic Sergipano orogenic belt, NE Brazil: a complete plate tectonic cycle in western Gondwana. Precambrian Research 181, 64-84.

Oliveira, R.G., 2008. Arcabouço Geofísico, Isostasia e causas do magmatismo cenozóico da Província Borborema e de sua Margem Continental (NE do Brasil) (PhD thesis). Universidade Federal do Rio Grande do Norte, Natal, p. 411.

Padilha, A.L., Vitorello., Í., Pádua, M.B., Marcelo., Fuck, R.A. 2016. Deep magnetotelluric signatures of the early Neoproterozoic Cariris Velhos tectonic event within the Transversal sub-province of the Borborema Province, NE Brazil. Precambrian Research 275, 7-83.

Rodrigues, S.W.O., Brito Neves, B.B., 2008. Padrões isotópicos Sm-Nd no limite entre os Terrenos Alto Pajeú e Alto Moxotó (PB). Revista Brasileira de Geociências 38, 211 227.

Santos, E.J., 1996. Ensaio preliminar sobre terrenos e tectônica acrecion_aria na Província Borborema. In: SBG, Congresso Brasileiro de Geologia, 39o, Salvador, Proceedings, pp. 47-50.

Santos, E.J., Medeiros, V.C., 1999. Constraints from granitic plutonism on proterozoic crustal growth of the Transverse Zone, Borborema Province, NE-Brazil. Revista Brasileira de Geociências 29, 73-84.

Santos, E.J., Brito Neves, B.B., Van Schmus, W.R., Oliveira, R.G., Medeiros, V.C., 2000. An overall view on the displaced terrane arrangement of the Borborema Province, NE Brazil. In: International Geological Congress, 31th, Rio de Janeiro, Brazil, General Symposia, Tectonic Evolution of South American Platform, pp. 5-9.

Santos, E.J., Nutman, A.P., Brito Neves, B.B., 2004. Idades SHRIMP U-Pb do Complexo Sertânia: implicações sobre a evolução tectônica da Zona Transversal, Província Borborema. Geol. USP - Série Científica 4, 1-12.

Santos, E.J., Van Schmus,W.R., Kozuch, M., Brito Neves, B.B., 2010. The Cariris Velhos tectonic event in northeast Brazil. J. South American. Earth Sciences. 29, 61-76. 
Santos, E.J., Van Schmus,W.R., Kozuch, M., Brito Neves, B.B., 2010. The Cariris Velhos tectonic event in northeast Brazil. J. South Am. Earth Sci. 29, 61-76.

Santos, L.C.M.L., Dantas, E.L., Santos, E.J., Santos, R.V., Lima, H.M., 2015. Early to late Paleoproterozoic magmatism in NE Brazil: the Alto Moxoto Terrane and its tectonic implications for the pre-West Gondwana assembly. Journal of South American Earth Sciences.58, 188-209.

Santos, L.C.M.L., Dantas, E.L., Santos, E.J., Santos, R.V., Lima, H.M., 2015a. Early to late Paleoproterozoic magmatism in NE Brazil: the Alto Moxoto Terrane and its tectonic implications for the pre-West Gondwana assembly. Journal of South American Earth Sciences.58, 188-209.

Santos, T.J.S., Amaral, W.S., Ancelmi, M.F., Pitarello, M.Z., Fuck, R.A., Dantas, E.L. 2015. U-Pb age of the coesite-bearing eclogite from NW Borborema Province, NE Brazil: Implication for western Gondwana assembly. Gondwana Research 28, 11831196.

Schermer, E., Howell, D.G., Jones, D.L. 1984., The origin of allochtonous terranes: perspectives on the growth and shaping of continents. Annual Reviews of Earth and Planetary Sciences 12, 107-131.

Schoene, B., Dudas, F.O.L., Bowring, S.A., de Wit, M. 2009. Sm-Nd isotopic mapping of lithospheric growth and stabilization in the eastern Kaapvaal craton. Terra Nova 21, 219-228.

Trompette, R., 1994. Geology of Western Gondwana, Pan African-Brasiliano Aggregation of South America and Africa. A.A. Balkema, Rotterdam, p. 350.

Van Schmus, W.R., Brito Neves, B.B., Hackspacher, P.C., Babinski, M., 1995. U/Pb and $\mathrm{Sm} / \mathrm{Nd}$ geochronologic studies of the eastern Borborema Province, Northeast Brazil: initial conclusions. Journal of South American Earth Sciences 8, 267-288.

Van Schmus, W.R., Kozuch, M., Brito Neves, B.B., 2011. Precambrian history of the Zona Transversal of the Borborema Province. Joutnal of South American Earth Sciences 31, 227-252. 
Van Schmus, W.R., Oliveira, E.P., Silva Filho, A.F., Toteu, F., Penaye, J., Guimarães, I.P., 2008. Proterozoic Links between the Borborema Province, NE Brazil, and the Central African Fold Belt. Geological Society, London, Special Publications 294, 6669.

Vauchez, A., Neves, S.P., Caby, R., Corsini, M., Edydio-Silva, M., Arthaud, M., Amaro, V.E., 1995. The Borborema shear zone system, NE Brazil. Journal of South American Earth Sciences 8, 247-266.

Zelek, M., Dickin, A. 2013. Nd isotope mapping of crustal terranes in the Parent-Clova Area, Quebec: Implications for the evolution of Laurentian Margin in the Central Grenville Province. Geosciences 3, 448-465. 


\section{SÍNTESE CONCLUSIVA}

A análise dos dados produzidos nesta tese demonstram que a evolução das faixas móveis precambrianas, incluindo a Província Borborema, é extremamente complexa e a cronologia e natureza dos seus diversos eventos tectônicos está ainda longe de ser inteiramente compreendida. Entretanto, algumas conclusões sobre o significado e relações entre os terrenos estudados foram obtidas, e sugerem que podem ser melhor interpretadas à luz da tectônica acrescionária. Dentro da Subprovíncia Transversal da Província Borborema, é sabido, embora não 100\% aceito, que os terrenos Alto Moxotó e Alto Pajeú possuem histórias geológicas contrastantes. Realizou-se também algumas inferências sobre a relação destes com o Terreno Pernambuco-Alagoas, apesar da pouca disponibilidade de dados referente a este último. Sendo assim, sugere-se que a área de trabalho é particularmente especial, pois apresenta uma longa história de acresção e retrabalhamento crustal que vai desde o Arqueano até o Neoproterozoico.

No âmbito do Terreno Alto Moxotó, evidências geoquímicas e geocronológicas, sugerem que a primeira atividade tectônica ocorreu no Neoarqueano (ca. 2,6 Ga). Esta, é marcada pela geração de magmas juvenis com algum componente crustal do tipo TTG (Suíte Riacho das Lajes), típicos de ambiente de subducção envolvendo fusão de crosta oceânica. A provável fonte para geração dessas rochas, envolve fusão de basaltos em condições de alta pressão (fácies eclogito), subductada perante um provável paleoplatô. Por outro lado, por volta de ca. $2.1 \mathrm{Ga}$, ocorreria o segundo evento tectono-magmático, envolvendo intenso retrabalhamento desta crosta mais antiga, mas também gerando bastante material juvenil em um novo processo de subducção. Tal episódio é extremamente complexo do ponto de vista petrogenetico, resultando no alojamento de magmas da Suíte Floresta, os quais apresentam ampla variedade de fontes, cobrindo episódios de fusão de crosta máfica, metassomatismo mantélico e menor contribuição de metassedimentos. Adicionalmente, durante o este período, é sugerido um mecanismo de slab breakoff coevo a esta acreção Riaciana, o que explicaria o comportamento geoquímico anômalo de algumas amostras estudadas, sobretudo, no que concerne a alguns elementos traço, tais como $\mathrm{Ni}, \mathrm{V}$ e $\mathrm{Ba}$.

O último pulso tectônico deste terreno é marcado por uma dualidade de ambientes durante a transição Estateriano-Caliminiano (ca. 1,6 Ga), resultando em intenso retrabalhamento do Terreno Alto Moxotó. Magmas graníticos relacionados a Suíte Riacho do Navio e Ortognaisse Coloete, localizados nas bordas deste terreno 
apresentam características petrográficas e geoquímicas compatíveis com magmas metaa peraluminosos tipo $\mathrm{S}$, sendo principalmente sin-orogênicos à colisionais. Por outro lado, a Suíte Carnoió, localizada no interior do terreno é correlata com a Serra da Barra, compartilhando características geoquímicas com magmas crustais gerados em ambiente intra-placa (magmas metaluminosos tipo A). Tal interpretação é sugestiva de que o Terreno Alto Moxotó se comportou como uma crosta rígida, embora retrabalhada durante todo o Paleoproterozoico, sendo fragmentada em torno de 1,6 Ga, embora, tenha também experimentando eventos acrescionários/colisionais em sua borda durante este período. Tal cenário apesar de pouco comum na América do Sul e único na Província Borborema, é descrito em diversas faixas orogênicas Paleoproterozoicas ao redor do mundo. A fragmentação de supercontinentes antigos como Columbia ou Atlântica, levou a formação de orógenos periféricos, os quais registram eventos de subducção/colisão em suas bordas coevos à intenso quebramento continetal.

Por outro lado, por meio de estudos geofísicos e isotópicos $(\mathrm{Sm}-\mathrm{Nd})$, foi possível identificar uma complexa história de colagem entre este bloco antigo e intensamente retrabalhado e os terrenos Alto Pajeú e Pernambuco-Alagoas durante o Neoproterozoico. Mapas geofísicos (magnetometria e radiometria) indicam contrastes significativos entre as associações litotectônicas, incluindo distintos valores de radionuclídeos, bem como anomalias magnéticas entre os terrenos e seus limites. Adicionlmente, análise estrutural meso- e microscópica com auxílio de lineamentos radiométricos e magnéticos identificados, marcam a cinemática e geometria das principais estruturas da região. De acordo com os resultados obtidos, as estruturas mais antigas estão presentes exclusivamente no interior do Terreno Alto Moxotó e, possuem dificil caracterização em função da forte transposição ocorrida durante $o$ Neoproterozoico (Toniano e Ediacarano). Sequencialmente, o desenvolvimento de tectônica de empurrão, resultou em um alinhamento de nappes e zonas de cisalhamento contracionais de direção E-W e vergência com transporte acima do mergulho para S-SE, sendo interpretadas como marcadores de colagem entre este terreno e o Alto Pajeú. De acordo com o modelo proposto, a Zona de Cisalhamento Serra de Jabitacá, que possui mergulho suave para NW e caráter sinuoso em função da fase deformacional posterior, registra caráter de aloctonia entre estes dois terrenos, sendo ainda espacialmente associada com ofiolitos de 1,0 Ga da Suíte Serrote das Pedras Pretas. Desta forma, sugere-se que tal evento ocorreu durante a Orogenia Cariris Velhos (1000-920 Ma). No 
entanto, não se descarta a possibilidade desta tectônica ter se desenvolvido nos primeiros estágios da orogenia Brasiliana (800-500 Ma), como é sugerido por alguns autores. Por fim, os elementos estruturais marcadores de tal colagem, são transpostos e fortemente obliterados por estruturas de caráter transcorrente de direção E-W e NE-SW, que são abundantes em toda Subprovíncia Transversal. Sugere-se que o Lineamento Pernambuco de direção E-W e cinemática dextral, teria atuado como responsável por colagem lateral entre o terreno composto Alto Moxotó-Alto Pajeú e o PernambucoAlagoas, de maneira similar à análogos Fanerozoicos, como a cordilheira NorteAmericana.

Análises Sm-Nd de 106 amostras de rochas metaplutônicas e supracrustais dos terrenos Alto Pajeú e Alto Moxotó, evidenciam que estes foram amalgamados em eventos acrescionários durante o Neoproterozoico, uma vez que apresentam fontes completamente distintas em idade e natureza. Enquanto que o Terreno Alto Moxotó é caracterizado por crosta mais antiga, o Alto Pajeú parece representar reservatórios isotópicos consideravelmente mais jovens. Além disso, os processos crustais dos quais estes terrenos foram submetidos, são completamente diacrônicos, sugerindo também que estes blocos não foram originados simultaneamente, não podendo assim coincidir com o modelo orogênico intracontinental recentemente advogado por alguns autores para a Província Borborema.

Os dados apresentados na presente tese são sugestivos, portanto, da atuação de processos acrescionários na colagem de diversos segmentos crustais constituintes da Província Borborema, tal como é descrito nas faixas africanas e orógenos Neoproterozoicos ao redor do mundo. Tal interpretação é também suportada por inúmeras evidências apresentadas na vasta literatura sobre o tema nos últimos anos, tais como: i) anomalias geofísicas próximas a zonas de falhas importantes, incluindo estudos de gravimetria e sísmica, ii) dados petrológicos, tais como as recentes identificações de fases metamórficas e alta à ultra-alta pressão, associadas à lineamentos transcontinentais, iii) discriminação de diversas associações plutônicas e vulcânicas com estreita relação com zonas de subducção e ambientes de colisão, tanto de idade Toniana, quanto Ediacarana e iv) descobrimento de remanescentes de crosta oceânica Neoproterozoica em várias porções da província. 
Em função do prazo, alguns dados obtidos não puderam ser expostos. Estes incluem análises geoquímicas e isotópicas dos metagranitoides Tonianos, mapeados como Suíte São Pedro, bem como, análise de proveniência por U-Pb em zircão nas rochas metassedimentares dos terrenos estudados. Estes dados são fundamentais para que a precisa cronologia da colisão TAP-TAM, bem como determinar se há continuidade dessas bacias ao longo dos limites de terrenos, embora os dados disponíveis na literatura sejam bastante robustos e indiquem que tais sequências devam possuir também fontes distintas de detritos.

Espera-se ainda, que os trabalhos vindouros, integrem os dados existentes bem como forneçam mais informações sobre as principais unidades da Sub Província Transversal e Província Borborema, principalmente relacionando dados geocronológicos com estudos geofísicos e análise estrutural. É também de igual importância, que sejam desenvolvidos trabalhos de petrologia metamórfica, de modo que seja possível uma melhor calibração das condições P-T dos terrenos e seus limites, confirmando ou não, possíveis zonas de sutura colisionais. Particularmente, acredito que futuras correlações entre dados obtidos nas faixas sul-americanas e africanas, eluscide muitos dos problemas existentes sobre a consolidação deste setor de Gondwana. 


\section{ANEXO 1 - ARTIGO CIENTÍFICO 5:}

\section{ANÁLISE TECTÔNICA DE TERRENOS: METODOLOGIA, APLICAÇÃO EM CINTURÕES OROGÊNICOS E EXEMPLO DAS PROVÍNCIAS TOCANTINS E BORBOREMA, BRASIL.}

Lauro Cézar Montefalco de Lira Santos ${ }^{1,2, *}$; Reinhardt A. Fuck ${ }^{1}$; Edilton José dos Santos ${ }^{3}$ Elton Luiz Dantas ${ }^{1}$

${ }^{1}$ Instituto de Geociências, Universidade de Brasília, Brazil; ${ }^{2}$ Unidade Acadêmica de Mineração e Geologia, Universidade Federal de Campina Grande, Brazil; ${ }^{3}$ Serviço Geológico do Brasil - CPRM, Brazil.

*Autor correspondente. E-mail: lauromontefalco@gmail.com

\section{Resumo}

Em regiões afetadas por tectônica convergente é comum a presença de um ou mais elementos alóctones que supostamente foram acrescidos à margem continental. Se esses elementos forem limitados por falhas ou zonas de cisalhamento importantes, são chamados de terrenos. Os terrenos apresentam tamanhos variáveis e, por vezes, representam fragmentos crustais alóctones, que podem apresentar histórias evolutivas individuais anteriores à sua acreção. Terrenos podem ser classificados em função de suas características individuais (estratigráficos, fragmentados ou metamórficos) e pelo tipo de acreção a que foram submetidos (frontal, lateral ou oblíqua). A análise de terrenos representa técnica multidisciplinar utilizada no estudo de cinturões orogênicos que tem como objetivo principal o entendimento dos diversos processos geodinâmicos relacionados a ambientes de subducção e complexos colisionais, sendo amplamente aplicada em diversas regiões do planeta. Em alguns orógenos pré-cambrianos brasileiros tem-se reconhecido padrões que permitem interpretar sua evolução como resultado de processos acrecionários e de colagem de terrenos, descritos em vários segmentos das províncias Tocantins e Borborema.

Palavras-Chave: Cinturões orogênicos, tectônica acrescionária, terrenos alóctones. 


\begin{abstract}
In regions affected by convergent tectonics, the presence of some allochtonous elements that were accreted to the continental margin is common. If these elements are bounded by important faults or shear zones, they are called terranes. Terranes present variable sizes and may represent allochtonous crustal fragments, with individual evolutive history previous to their accretion to the continental margin. Terranes can be classified as a function of its individual characteristics (stratigraphic, disrupted or metamorphic) and formed by frontal, lateral or oblique accretion. Terrane analysis represents a multidisciplinary technique used in studying orogenic belts that aims the understanding of several processes related to subduction and collisional complexes. Certain patterns recognized in some Brazilian Precambrian orogens allow to interpret their evolution as the result of accretion tectonic events recorded in the Tocantins and Borborema provinces.
\end{abstract}

Key-words: Orogenic belts, Accretion Tectonics, Allochtonous Terranes.

\title{
8.1. Introdução
}

Cinturões orogênicos constituem províncias estruturais complexas, que podem ter sido submetidas a diversos episódios tectônicos, magmáticos e metamórficos. Frequentemente, esses processos dificultam estudos genéticos e correlações estratigráficas, além de obliterar estruturações anteriores, comprometendo a análise evolutiva. Modelos pioneiros de tectônica de placas em cinturões orogênicos enfatizavam principalmente seções ortogonais à direção regional do orógeno, não levando em consideração a possibilidade de importantes deslocamentos longitudinais ou oblíquos. Estes modelos, entretanto, não satisfaziam o entendimento de cinturões orogênicos complexos como, por exemplo, a Cordilheira Norte Americana.

Boa parte dos orógenos conhecidos apresenta ao menos uma região cujos elementos estratigráficos devem ser considerados potencialmente alóctones, com respeito às correlações paleogeográficas seja com relação aos seus próprios elementos ou à margem continental (Howell, 1995). Este trabalho apresenta os principais elementos envolvidos na análise tectônica de terrenos, demonstrando sua importância, com aplicação dos conceitos nas províncias Tocantins e Borborema. 


\subsection{Histórico do modelo e conceituação}

Tendo em vista as complicações envolvidas nas correlações estratigráficas, estruturais e paleontológicas observadas nos orógenos ditos cordilheiranos, o modelo de tectônica acrescionária e de terrenos vem sendo utilizado ao redor do mundo para explicar as diversas relações de aloctonia. O modelo teve sua origem na região das montanhas Klamath, norte da Califórnia, Estados Unidos da América. A geologia da região foi pioneiramente dividida por Irwin (1960) em uma série de cinturões com evolução estrutural e estratigráfica distinta. Cada cinturão foi dividido em sub-cinturões, chamados posteriormente de terrenos (Irwin, 1972). Na mesma época, autores como Monger e Ross (1971) sugeriam que alguns terrenos poderiam ser alóctones, como alguns blocos crustais exóticos da Cordilheira em relação ao continente norteamericano.

Na década de 1970 diversos trabalhos enfatizaram a importância de zonas de cisalhamento ou falhas paralelas como elementos estruturais importantes na evolução de cinturões orogênicos. Esses estudos eram associados a dados paleontológicos e paleomagnéticos, com o objetivo de obter informações quantitativas ou qualitativas sobre grandes deslocamentos paralelos ou sub-paralelos à margem continental (Irving e Yole, 1972; Packer e Stone, 1972). Ao final da década de 1970, Jones et al. (1977), pioneiramente propuseram uma trajetória de deslocamento específica para o bloco crustal Wrangellia. De acordo com as interpretações desses autores, Wrangellia teria se originado no Oceano Pacífico e se deslocado para leste até ser acrescido à Placa NorteAmericana, sendo considerado um caso clássico de terreno de afinidade exótica ou fartravelled. O Terreno Wrangellia teria ainda sido deslocado por falhamentos transcorrentes na própria margem continental por processos pós-acrecionários de dispersão.

$\mathrm{Na}$ década seguinte o conceito de terrenos foi consolidado pelos trabalhos clássicos de Coney et al. (1980) e Jones et al. (1983), sendo discretamente modificado por Howell $(1989,1995)$. De acordo com estes autores, um terreno tectonoestratigráfico corresponderia a um pacote de rochas limitado por falhas ou zonas de cisalhamento importantes (possíveis suturas) com estratigrafia, ambiente e história geológica distintas dos terrenos adjacentes. 
A aplicação direta do modelo tem sido utilizada em faixas móveis de diversas idades, cobrindo todo o Fanerozoico e a maior parte do Pré-Cambriano, tais como a própria Cordilheira Norte-Americana (Coney et al. 1980; Colpron et al. 2007), toda a região do Circum-Pacífico (Schermer et al. 1984; Mortimer, 2004), Apalaches (Williams e Hatcher 1982), terrenos pré-cordilheiranos na Argentina (Ramos et al. 1998), província Grenville (Mallard e Rogers, 1998), Namaqua-Natal (Ellington, 2006) e Yavapai-Mazatzal (Magnani et al. 2004), os escudos Tuareg (Black, 1994) e ArábicoNubiano (Stoeser and Frost, 2006; Cox et al., 2012), além de crátons arqueanos, como Yilgarn na Austrália e Slave no Canadá (Zegers e van Keken, 2001; Griffin et al. 2004; Helmstaedt 2009). No Brasil, estudos modernos têm proposto que as províncias Borborema, Mantiqueira, Rondônia-San Ignacio e Sunsás foram edificadas por mecanismos de colagem e acreção de terrenos (Santos 1996; Hackspacher et al., 1997; Brito Neves et al. 2000; Scandolara et al., 2001; Rizzotto e Quadros, 2005; Basei et al. 2008; Heilbron et al. 2008; Faleiros et al. 2011).

De acordo com a classificação apresentada por Howell (1995), terrenos tectonoestratigráficos podem ser agrupados em três categorias, em função de sua organização interna:

\subsubsection{Terrenos estratigráficos}

Caracterizados por sequências de estratos, cujas relações deposicionais podem ser demonstradas. Podem representar fragmentos de continentes, fragmentos de margens continentais, fragmentos de arcos magmáticos e fragmentos de bacias oceânicas. Ex: Terreno Torlesse, Nova Zelândia.

\subsubsection{Terrenos metamórficos}

Terrenos nos quais a recristalização metamórfica penetrativa obliterou completamente a estratigrafia original. Ex: Terreno Tamana, Alasca.

\subsubsection{Terrenos fragmentados}

Caracterizados pela presença de blocos de rochas com idades heterogêneas. Podem conter fragmentos de ofiolitos, calcários marinhos, grauvacas, etc. Ex. Central Belt Terrane, Califórnia. 


\subsection{Conceitos complementares}

Alguns termos específicos surgiram para abranger as diversas descrições de cinturões orogênicos que experimentaram tectônica de terrenos. Os termos são apresentados a seguir segundo as definições compiladas de Schermer et al., (1984), Howell (1995) e Brito Neves (2011).

i) Terrenos exóticos - Áreas circundadas por suturas e caracterizadas por contingente petrográfico, estratigráfico, paleontológico e/ou paleolatitudes distintas dos terrenos vizinhos.

ii) Terrenos compostos - Conjunto formado por uma série de terrenos individualizáveis que foram amalgamados em algum momento de suas trajetórias.

iii) Terrenos disjuntos - Terrenos que são espacialmente correlacionáveis, mas espacialmente distintos.

iv) Eventos externos e internos - Eventos que ocorreram em algum momento que antecede a acreção à margem continental (externos) ou posteriores à acreção (internos).

v) Docagem - Em regimes de subducção, na região da fossa, aportam fragmentos de crosta continental, frações de arcos de ilhas, platôs submarinos. Estes fragmentos tendem a colidir como terrenos.

vi) Limite de Terrenos - Comumente são definidos como zonas de sutura ou falhas/zonas de cisalhamento de grande expressão.

\subsection{Mecanismos de colagem e fragmentação de terrenos}

Vários mecanismos foram propostos para explicar processos de formação e trajetória de terrenos. O resultado mais imediato na acreção de terrenos é sempre (ou quase) o crescimento crustal, mas eventos de retrabalhamento e reciclagem crustal também podem estar associados. Crescimento crustal é o resultado da adição progressiva de material às margens continentais. Um caso clássico é a Cordilheira Norte-americana, onde os diversos terrenos adicionaram material à margem oeste de Laurentia no fim do Paleozoico (Coney et al., 1980). 
Durante a evolução de terrenos, dois processos fundamentais estão envolvidos (Schermer et al. 1984): i) Construção e ii) Destruição e modificação continental.

\subsubsection{Construção (Amálgamação e Acreção)}

Amalgamação de terrenos ocorre quando dois terrenos colidem anteriormente a um episódio acrescionário. Acreção refere-se à adição de terrenos a uma margem continental, culminando em processo de docagem. Acreção é um processo muito importante, pois pode afetar consideravelmente a história evolutiva do terreno, obscurecendo ou obliterando feições anteriores.

Durante eventos acrecionários, zonas de cisalhamento inversas representam os elementos estruturais mais importantes, principalmente em processos de colagem frontal de terrenos à margem continental (Figura 8.1). Zonas de cisalhamento de alto ângulo, no entanto, também representam importantes elementos estruturais, em consequência de acreção oblíqua ou colagem lateral, ou ainda em virtude de reativação de falhas contracionais antigas.

Ao longo destes processos, é comum a formação de mélanges e rochas metamórficas de alta pressão (xistos azuis ou eclogitos), como no caso dos terrenos Yolla Bolly e Picket Peak do Complexo Franciscano (oeste dos Estados Unidos da América), que são terrenos metamórficos submetidos a condições de fácies xisto azul, associados a eventos de acreção (Jayko e Blake, 1989; Bolhar e Ring, 2001). Por outro lado, é comum metamorfismo de alta temperatura, com formação de fundidos anatéticos como, por exemplo, a atividade magmática e metamórfica produzida pela intrusão do Coast Plutonic Complex na Columbia Britânica (região oeste do Canadá) (Monger et al. 1982). Outro aspecto importante na indicação de acreção de terrenos é a presença de ofiolitos, vinculados a regimes de obducção sin-acrescionária e preservados em casos de baixas taxas de exumação do orógeno. 


\section{E. PERMIANO}

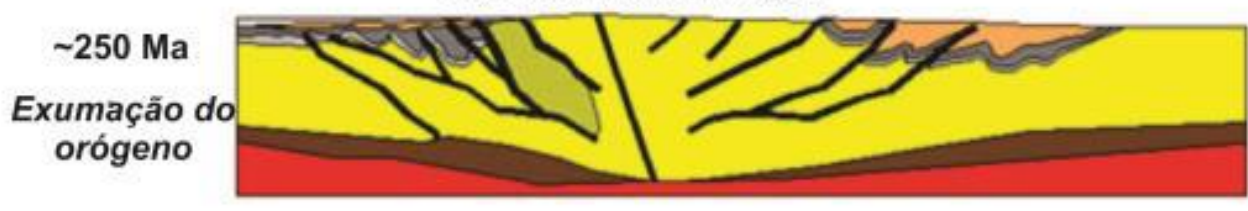

D. PENSYLVANIANO
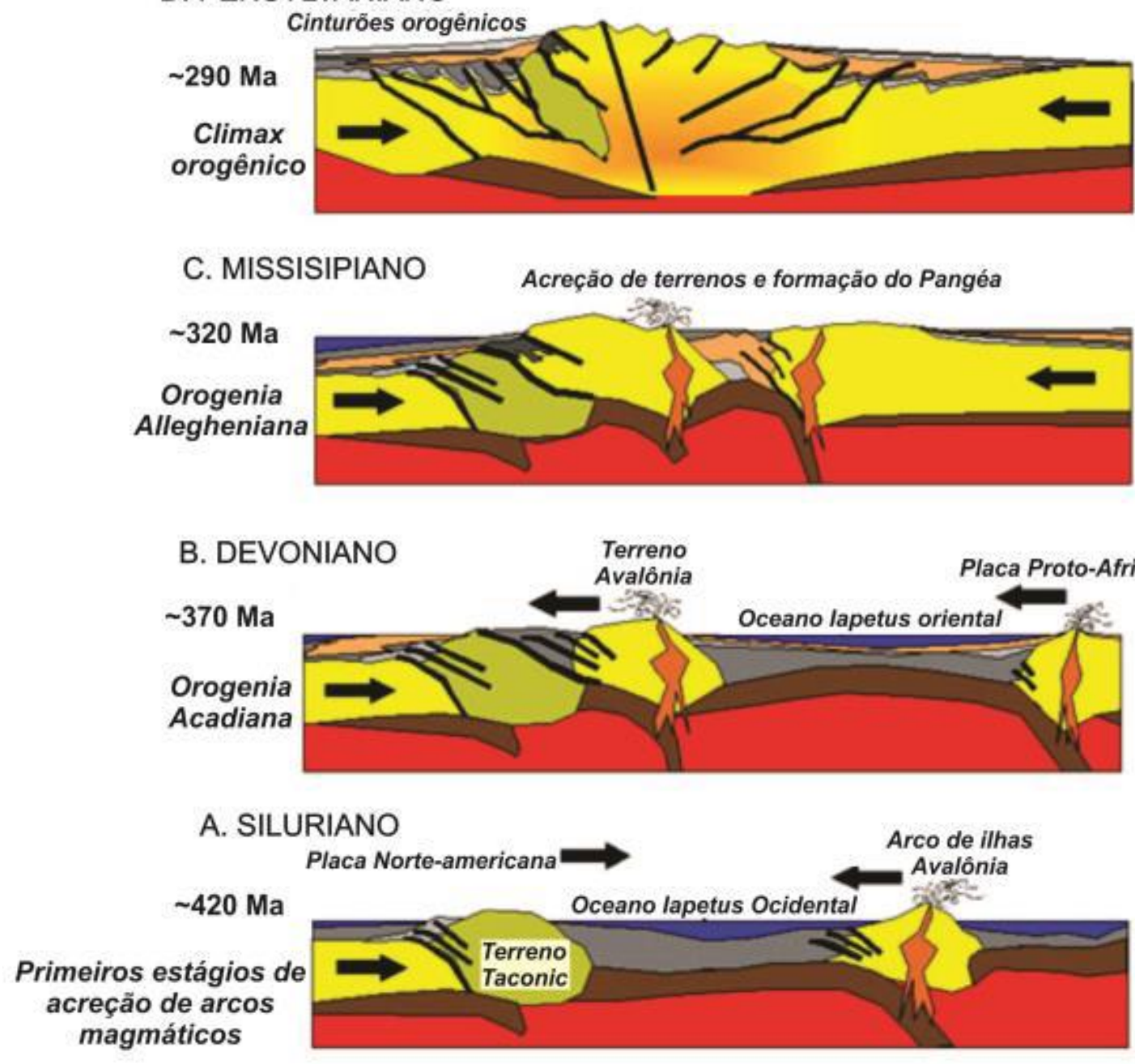

Figura 8.1 - Diagrama tectônico demonstrando acreção de dois terrenos por meio de colagem frontal (Tacônico e Avalônia) nos Apalaches da Nova Inglaterra. Retirado de http://3dparks.wr.usgs.gov/nyc/valleyandridge/valleyandridge.htm.

\subsubsection{Destruição ou modificação continental (Rifteamento e Dispersão)}

De maneira oposta à construção continental, eventos de destruição e modificação continental obliteram limites de terrenos. De acordo com Howell (1995) e Schermer et al. (1984), dispersão é o processo no qual terrenos previamente amalgamados são divididos em fragmentos menores e espalhados ao longo da margem continental. 
O processo pode ocorrer por meio de rifteamento ou por falhas de movimentação direcional (Figura 8.2), inclusive durante eventos de acreção ou colagem, como no caso de subducção oblíqua. Exemplo desse tipo de processo é a falha de San Andreas na costa oeste dos Estados Unidos da América, que apresenta forte componente dispersivo, bem como os sistemas de falhas de Fairweather, Denali e Tintina, no contexto da Cordilheira Norte-Americana. Dispersão de terrenos é descrita ao longo de quase toda margem do Pacífico, tanto relacionados a subducção oblíqua ou essencialmente a deslocamentos transcorrentes.

Processos de dispersão devem ser estudados em detalhe e com cautela, pois são responsáveis pela formação de terrenos disjuntos. Estes terrenos podem ser estratigraficamente correlacionados, porém não apresentam boa correlação espacial. O melhor exemplo é o terreno Wrangellia mencionado anteriormente. Este terreno ocorre seccionado por lineamentos de extensão regional. Dados paleomagnéticos indicam que estas fatias crustais eram significativamente menores (Hillhouse et al. 1982).

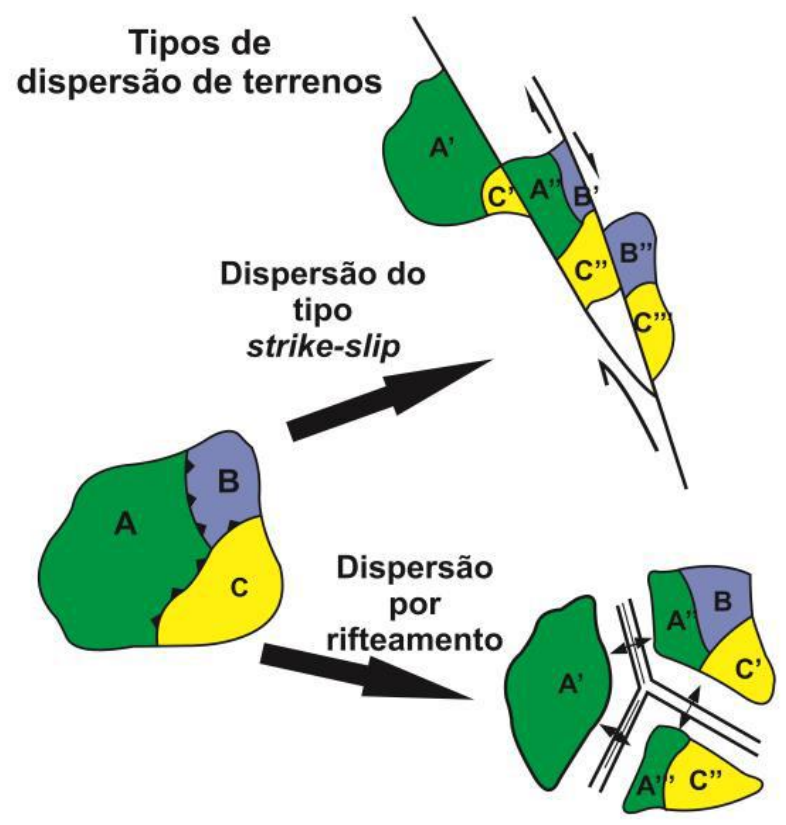

Figura 8.2 - Representação dos dois principais processos de dispersão de terrenos modificado de Howell 1995. 


\subsection{Platôs oceânicos e terrenos}

Aproximadamente $10 \%$ da crosta oceânica atual são formados por segmentos espessos caracterizados por altos batimétricos e margens íngremes. Essas regiões são chamadas de platôs oceânicos e são interpretados como restos de fragmentos de continentes, traços de hot-spots, arcos remanescentes ou diversos tipos de pilhas vulcânicas (Nur e Ben-Avraham, 1981; Schubert e Sandwell, 1989; Vogt e Geria, 2012).

A natureza original de platôs oceânicos é conhecida por meio de dados de sondagem ou dragagens do assoalho oceânico. Alguns platôs representam fragmentos continentais, tais como o Platô de Campbell (Grobys et al. 2009) próximo à Nova Zelândia e Kerguelen no Oceano Índico (Frey et al. 2000), enquanto outros foram originados a partir de ilhas oceânicas ou restos de arcos magmáticos remanescentes, como a elevação de Galápagos e o platô Kyushi Palau, localizado próximo às Filipinas (Schermer et al., 1984).

Independente de sua origem, platôs são considerados precursores de terrenos, tendo como destino final a docagem a uma margem continental por meio de processos de acreção e colisão, independente de eventos de amálgama pré-acreção (Schubert e Sandwell, 1989). Entretanto, platôs oceânicos não são exatamente terrenos tectonoestratigráficos, pois não representam fragmentos crustais limitados por falhas, embora seja reconhecido que ao encontrar uma margem continental ativa, a tendência geral seja de se tornar um terreno alóctone, sendo, por fim, soldado à margem continental. Esta interpretação é baseada no fato de que muitos terrenos possuem similaridades geoquímicas e geocronológicas com platôs oceânicos, sugerindo se tratarem de paleo-platôs. Exemplos de platôs oceânicos que foram acrescidos a zonas de subducção fósseis e modernas correspondem aos Platôs de Okhotsk, Shirhove Ridge e Carnegie Ridge (Schermer et al., 1984), no contexto circum-pacífico. Os terrenos Wrangellia e Cache Creek na cordilheira norte-americana são exemplos de terrenos alóctones que correspondem a paleo-platôs. 


\subsection{Características de terrenos}

\subsubsection{Limites}

Como exposto em seu conceito original, todo terreno deve ser separado dos terrenos adjacentes por falhas ou zonas de cisalhamento. As estruturas em limites de terrenos podem estar associadas a conjuntos petrotectônicos variados, tais como cinturões alinhados formados por mélanges, corredores regionais miloníticos a ultramiloníticos, duplexes compressivos e tectônica de nappes. A associação com rochas metamórficas específicas como xistos azuis ou a eclogitos do tipo C (Coleman et al. 1965) é um indicativo de processos acrescionários.

Por outro lado, em muitos limites as zonas de falha ou cisalhamento não possuem expressão regional em imagens de satélites, mapas geofísicos ou em fotografias aéreas. Em geral, este é o caso de vários terrenos pré-cambrianos, sendo tais limites ditos ocultos (cryptic), imperceptíveis. É comum ainda que muitos limites possam ter seu registro apagado por eventos deformacionais posteriores.

Schermer et al. (1984) e Howell (1995) advogam que limites entre terrenos podem ser muitas vezes inferidos por meio de comparação de áreas com unidades estratigráficas contrastantes e não necessariamente correspondem a suturas.

\subsubsection{Tamanho}

Terrenos podem variar consideravelmente de tamanho, desde dimensões continentais a áreas de poucos quilômetros quadrados. Fragmentos continentais espessos, arcos de ilhas, flakes e fatias tectônicas podem ser considerados terrenos, desde que se adequem aos critérios conceituais. Por outro lado, a escala de análise é de fundamental importância para determinar quantos e quais fragmentos devem ser considerados terrenos.

\subsection{Deslocamentos e trajetórias}

Os deslocamentos que um terreno pode sofrer também são variáveis, podendo apresentar deslocamentos em escala continental, ou não maiores do que alguns quilômetros. Medidas de deslocamento de terrenos podem ser feitas de várias formas, desde técnicas geológicas convencionais (análise estrutural, estudos estratigráficos, 
evidências de aparecimento ou desaparecimento de paleofauna) ou até métodos sofisticados como Paleomagmetismo. Esta última corresponde a uma técnica bastante robusta, pois determina deslocamentos latitudinais em escalas regionais ou até globais, podendo definir trajetórias dos diversos terrenos como mostram Schermer et al. (1984).

\subsection{Evidências de formação de terrenos}

Algumas feições estruturais e estratigráficas podem registrar o timing de episódios de amálgama e de acreção, adicionando valiosa informação à análise de terrenos (Figuras 3.3 e 3.4). Howell (1995) define algumas feições fundamentais:

i) Sequência de Sobreposição (Overlap Sequence) - Quando dois ou mais terrenos são amalgamados, existe a possibilidade de uma bacia sedimentar se desenvolver sobre a zona de sutura; neste caso uma camada sedimentar pode recobrir ambos os terrenos, representando, assim, o tempo mínimo (timing) pós-colagem. Um bom exemplo é a Formação Chuckanut (Paleoceno) depositada sobre os terrenos ocidentais da região da Colúmbia Britânica. A formação apresenta registro paleontológico rico. A idade de deposição, particularmente de sua seção basal, determina a idade mínima da colagem (Howell, 1989, 1993; Mustoe e Gannaway, 1997).

ii) Suturamento Plutônico (Stitching Plutons) - Acreção de terrenos a uma margem continental em geral é um processo acompanhado de intensa atividade magmática, em especial plutônica. Quando plutonismo ocorre alinhado à zona de sutura/falha, datação radiométrica direta (U-Pb em zircão magmático) pode fornecer a idade mínima do amálgama. Esta técnica é particularmente importante em terrenos pré-cambrianos, devido à escassez de conteúdo fossílifero para eventuais correlações. Exemplo clássico é o suturamento plutônico atribuído ao Pennsylvanian pluton, relacionado com o registro da colagem dos terrenos Wrangellia e Alexander, na costa oeste norte-americana (Gardner et al. 1988).

iii) Soldagem Metamórfica (Metamorphic Welding) - Em casos de metamorfismo regional pervasivo registrado em terrenos, a idade do metamorfismo pode 
informar a idade mínima do amálgama. A indicação de metamorfismo jurássico relacionado à colagem de terrenos da Nova Zelândia, particularmente entre os terrenos Caples e Torlesse, representa bom exemplo de soldagem metamórfica (Adams et al. 1998).

iv) Ligação de Proveniência (Provenancial Link) - Quando evidências de suturamento plutônico e overlap estratigráfico não estão acessíveis ou são inexistentes, a cronologia dos eventos acrecionários pode ser inferida por variações composicionais em rochas clásticas. Um exemplo são fluxos de detritos (debris flows) com materiais de terrenos bem conhecidos depositados sobre outro terreno. Embora indireto, este critério pode fornecer boas indicações com respeito ao momento do episódio acrecionário. A análise detalhada de proveniência do Grupo Nanaimo (SW da Colúmbia Britânica, Canadá), por exemplo, determinou fontes distintas que devem ser relacionadas à colagem de terrenos. Assim, conhecidas as relações estratigráficas com terrenos, dados geocronológicos em sequências sedimentares ou metassedimentares permitem inferir o período de duração do amálgama e/ou acreção (England e Hiscott, 1992; Mustard et al., 1994, 2000).

v) Geo-história - Além dos elementos já apresentados, Howell (1995) enfatiza a importância de técnicas de análise geológica convencional, tais como observações de variações laterais de litofácies e análise estratigráfica dos possíveis candidatos a terrenos. Estudos de petrologia, por outro lado, podem sugerir evidências de atividades magmáticas distintas ou contrastantes, sejam juvenis ou fruto de retrabalhamento crustal, fornecendo, assim, forte indício de colagem. Dados estruturais podem sugerir transporte ou inversões tectônicas importantes. Qualquer evidência que indique origem distinta entre dois domínios adjacentes pode ser sugestiva de limite de terrenos. 
Sequência de sobreposição

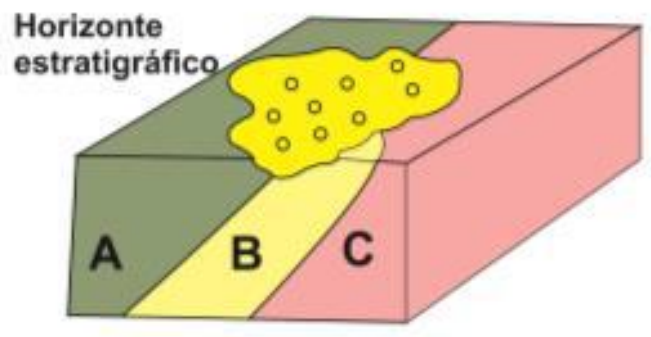

\section{Soldagem Metamórfica}

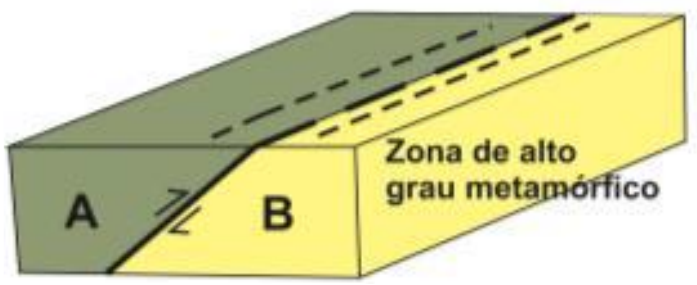

\section{Suturamento Plutônico}

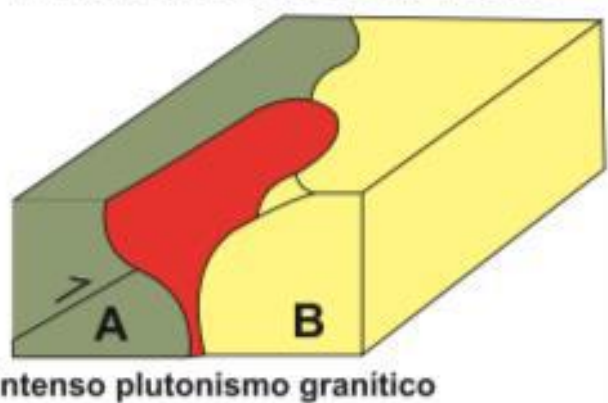

Ligação de proveniência

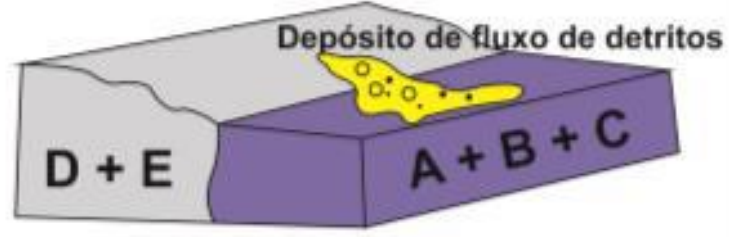

Figura 8.3 - Diagramas esquemáticos exemplificando os resultados da amalgamação de terrenos em função do mecanismo. A, B e C são terrenos de natureza indefinida, enquanto $\mathrm{A}+\mathrm{B}+\mathrm{C}$ e $\mathrm{D}+\mathrm{E}$ representam terrenos compostos. (Modificada de Howell, 1995). 


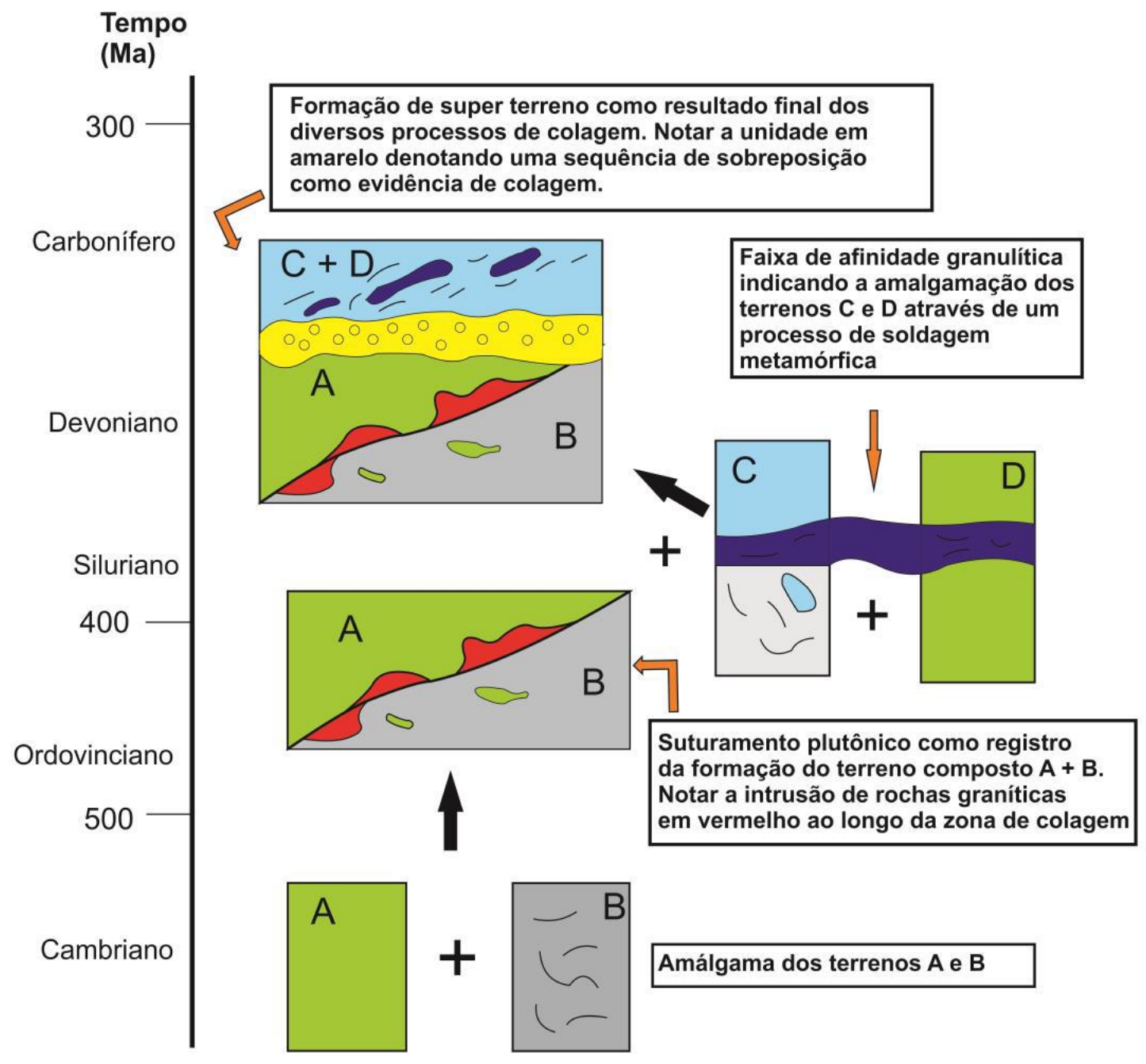

\section{LEGENDA}

Terreno Paleoproterozoico de afinidade ofiolitica

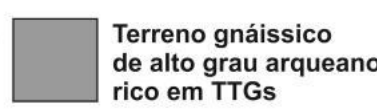

Terreno de afinidade continental com cobertura Neoproterozoica

Figura 8.4 - Diagrama de assembléia tectônica (hipotético), mostrando uma sequência de colagem de terrenos de afinidades (e idades) distintas através dos diversos processos de amalgamação. Notar que os eventos não são necessariamente excludentes e podem sobrepor-se no tempo (Baseado em modelos similares apresentados por Howell, 1995).

\subsection{Técnicas utilizadas na análise tectônica de terrenos}

A análise de terrenos corresponde a uma série de estudos, à luz da tectônica de placas, que fornecem informações a respeito da origem e dos movimentos de blocos crustais considerados potencialmente alóctones. Uma vez que um determinado terreno é 
identificado e tem seus limites reconhecidos, a primeira fase da análise se dá pela sua caracterização individual, seguida pelo estudo de suas relações com os terrenos adjacentes.

Análise estrutural e estratigráfica de detalhe devem ser os estudos pioneiros no processo de entendimento da origem e evolução de terrenos. O primeiro passo é o mapeamento geológico criterioso com o objetivo de determinar as relações entre determinado terreno e a margem continental bem como sua relação com os terrenos adjacentes (Samson et al. 1991). Dados de geofísica aérea regional podem ser particularmente importantes nesta etapa do trabalho.

Algumas técnicas específicas vêm sendo aplicadas em estudos paleogeográficos, tal como paleomagnetismo. Paleomagnetismo é o estudo do registro do campo magnético terrestre nas rochas (Butler, 1998). Neste tipo de pesquisa, as medidas de magnetismo sempre devem ser associadas à geocronologia, com objetivo de registrar o timing do magnetismo termo-remanente, obtendo-se assim, informações diretas sobre o campo magnético terrestre na época do resfriamento do mineral. O principal objetivo de estudos paleomagnéticos em análise de terrenos é determinar se alguma anomalia magnética indica a movimentação de determinado terreno em relação ao polo magnético, ou a rotação do terreno como um todo ou de blocos menores em seu interior (Howell, 1995).

Outra técnica particularmente importante na análise de terrenos é a aplicação de dados de fósseis na determinação paleogeográfica, com a utilização da chamada análise paleobiogeográfica (Haggart et al. 2006).O preceito básico é que conteúdos fossíliferos bem conhecidos determinam idades de deposição em bacias e condições paleogeográficas dos ambientes em que viveram. A distribuição geográfica dos organismos no planeta (biogeografia) é tipicamente limitada pela variação de fatores ambientais, tais como umidade, temperatura, salinidade ou ainda distribuição de nutrientes. Estudos paleobiogeográicos aplicados à análise de terrenos envolvem basicamente a comparação de distribuição espacial e temporal de fauna e flora entre os terrenos para obtenção de informações indiretas sobre os principais deslocamentos.

Embora paleomagnetismo e estudos paleontológicos sejam extremamente eficientes no entendimento de cinturões orogênicos fanerozoicos, em terrenos précambrianos podem ser bastante limitados. Neste caso outras técnicas adicionais podem 
fornecer evidências sobre eventos acrecionários, tais como litogeoquímica e geologia isotópica.

A utilização de isótopos de $\mathrm{Nd}$ vem dando grande contribuição para a análise de terrenos mais antigos, pois permite a identificação de fontes distintas entre as unidades potencialmente alóctones e a margem continental. Esta técnica tem sido aplicada em diferentes cinturões orogênicos paleozoicos e pré-cambrianos como, por exemplo, na separação detalhada de terrenos dos Apalaches (Wortman et al. 1996; Samson et al,. 1995). Outro bom exemplo de aplicação é apresentado por Zelek e Dickin (2013) para a região de Parent-Clova (Quebec, Canadá). Com base em mais de 100 análises correspondentes à porção central da Província Grenville, os autores separaram três regiões isotópicas distintas; uma arqueana na porção norte, uma central com idades mistas, interpretada como arco ensiálico e uma no sul, interpretada como resultado de extensão mesoproterozoica (Figura 8.5). A conclusão final dos autores é de que os distintos domínios isotópicos identificados representariam terrenos de origens contrastantes. Como exemplos brasileiros, contrastes isotópicos foram identificados em blocos crustais da Faixa Ribeira, como demonstram (Dantas et al., 2000; Figura 8.6) e entre os terrenos Alto Moxotó e Alto Pajeú da Província Borborema (Rodrigues e Brito Neves, 2008).

Datações radiométricas, especialmente geocronologia U-Pb em zircão são indispensáveis para a identificação de fragmentos exóticos ou alóctones, seja na determinação de idades de cristalização de magmas com origens contrastantes, seja na datação de grãos detríticos de zircão, ora determinando sequências de sobreposição ou mesmo fontes distintas. A aplicação de datações absolutas associadas com isótopos de Hf tem representado ferramenta robusta em estudos de proveniência e caracterização de fontes (Kinny e Maas, 2003). Exemplos de aplicações de análises isótopicas na definição de origem de terrenos são descritos em vários cinturões orogênicos ao redor do mundo, com particular destaque na identificação dos diversos períodos acrecionários dos terrenos cordilheiranos (Monger e Nokleberg, 1996; Monger e Price, 2002; Grove et al., 2008; Bermanek et al., 2012). Os principais conceitos e elementos envolvidos em análise de terrenos podem ser observados no fluxograma apresentado na Figura 8.7. 


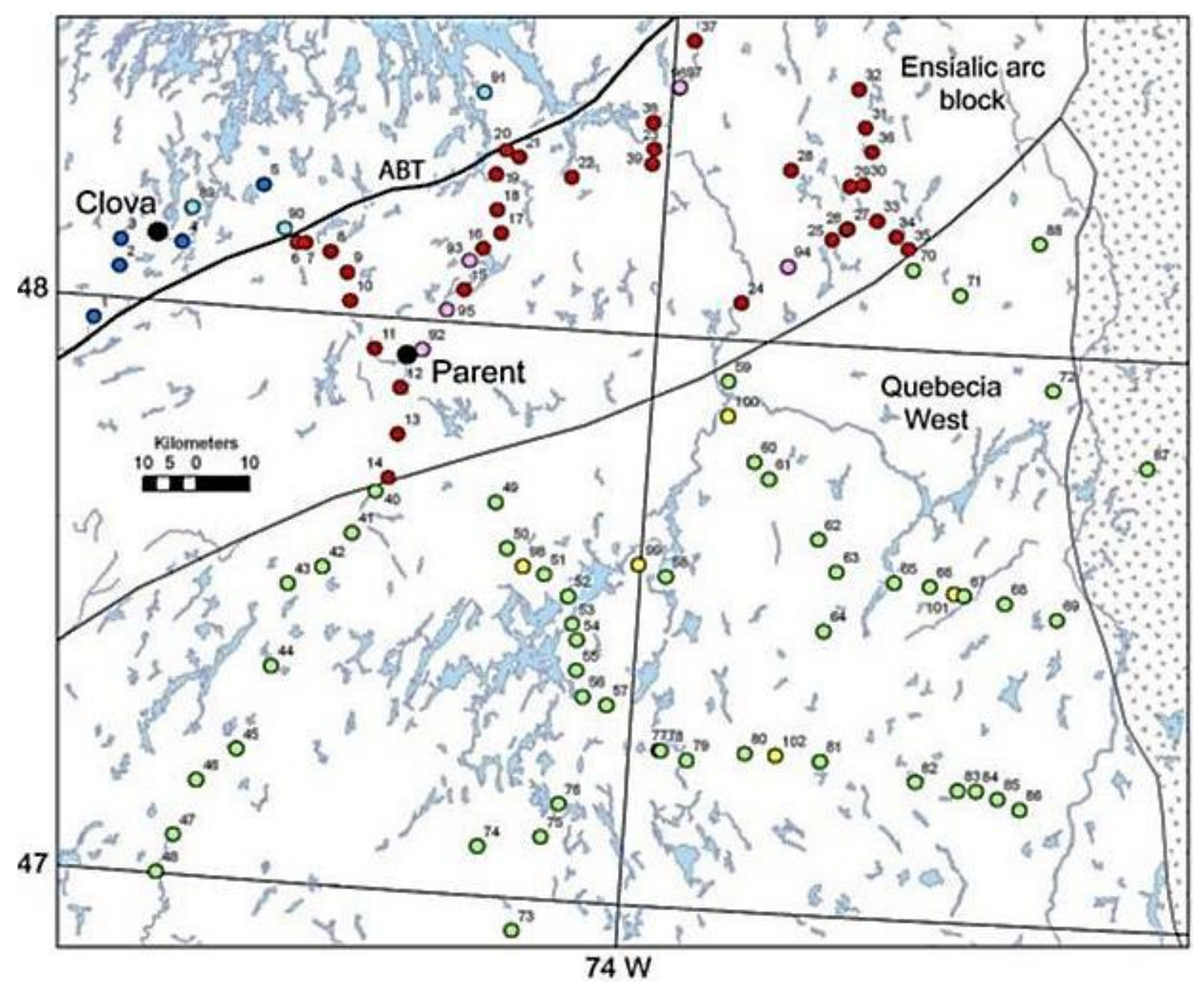

Figura 8.5 - Distribuição geográfica das análises apresentadas por Zelek e Dickin 2013 na região de Parent-Clova (Quebec). Os círculos de cor azul escura representam rochas com idades modelo TDM mais velhas que 2,4 Ga; vermelha, amarela e azul pálido, rochas entre 2,4 e 1,64, verde e rosa entre 1,64 e 1,37 Ga, demonstrando claramente três domínios isotópicos distintos e eficiência do método na caracterização de terrenos na Província Grenville. 

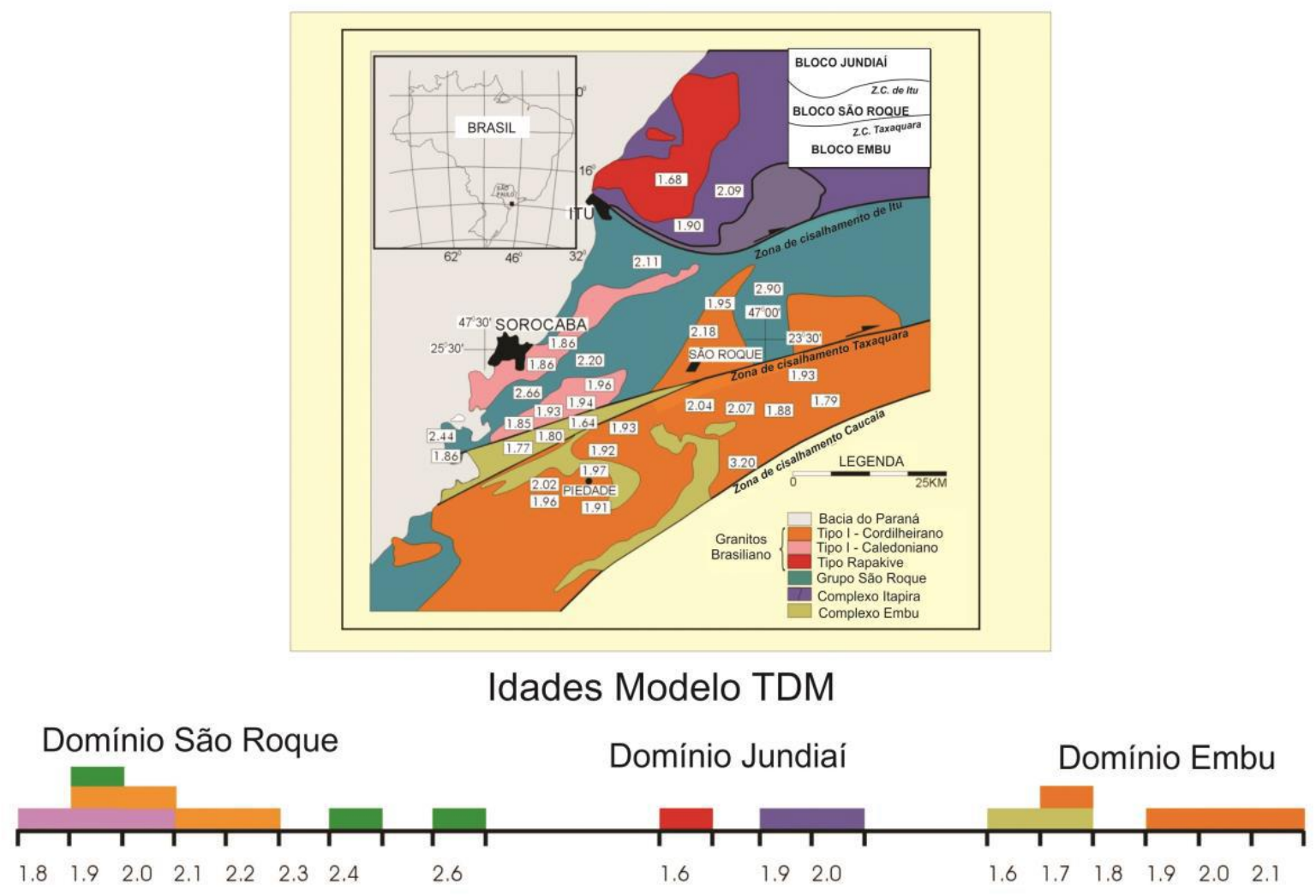

Figura 8.6 - Distribuição de idades modelo TDM de isótopos de Nd na Faixa Ribeira no estado de São Paulo de acordo com Dantas et al., 2000. O contraste isotópico entre os distintos domínios limitados pelas falhas de Itu, Taxaquara e Caucaia pode ser interpretado como um indício de tectônica acrescionária.

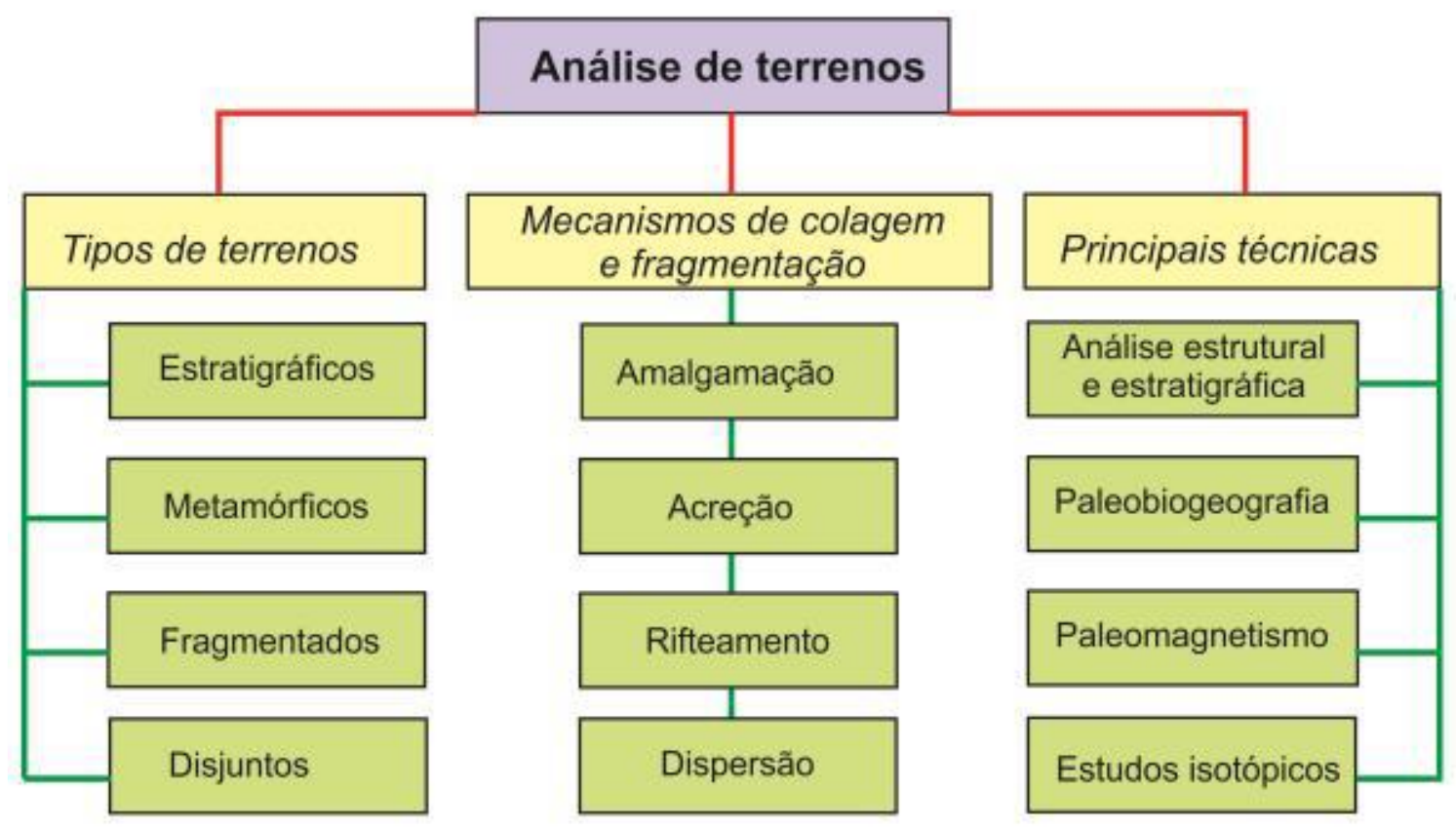

Figura 8.7 - Síntese dos principais elementos utilizados na análise tectônica de terrenos. 


\subsection{Registro de tectônica acrescionária em províncias Neoproterozoicas brasileiras}

\subsubsection{Província Tocantins (Brasil Central)}

A Província Tocantins (Almeida et al., 1981) é uma extensa área orogênica neoproterozóica resultante da convergência e colisão dos paleocontinentes Amazônico e São Francisco (Figura 8.8). Convergência e colisão ocorreram durante a Orogenia Brasiliana, no Neoproterozoico tardio, como parte do amálgama de Gondwana ocidental. Rochas sedimentares e vulcânicas fanerozoicas das bacias do Parnaíba, Paraná e Sanfranciscana recobrem partes da província, bem como blocos continentais estáveis mais antigos, os blocos Parnaíba e Paranapanema, ambos também envolvidos na Orogenia Brasiliana. A província compreende três faixas móveis: as faixas Araguaia e Paraguai foram formadas nas margens leste e sudeste do Cráton Amazônico, respectivamente, enquanto a Faixa Brasília ocupa as margens oeste e sul do Cráton do São Francisco.

As distintas associações petrotectônicas reconhecidas permitem a compartimentação da Faixa Brasília em zona externa e zona interna (Fuck et al., 2014 e referências ali contidas). A zona externa é constituída por cinturão de dobras-falhas composto por rochas metassedimentares de margem passiva e seu embasamento. A zona interna compreende nappes de médio e alto grau do Grupo Araxá e do Complexo Anápolis-Itauçu, o Maciço de Goiás e o Arco Magmático de Goiás, todos com vergência para o Cráton do São Francisco.

O Maciço de Goiás é constituído por terrenos granito-greenstone arqueanos e ortognaisses e sequências supracrustais paleoproterozoicas, cobertas em parte pelas rochas metassedimentares do Grupo Serra da Mesa e justapostas a leste a sequências vulcanossedimentares e complexos gabro-anortosíticos mesoproterozóicos e aos complexos máfico-ultramáficos neoproterozoicos Barro Alto, Niquelândia e Cana Brava, que formam sua borda leste.

No contexto da Faixa Brasília e da Província Tocantins e em comparação com os demais elementos tectonoestratigráficos da faixa, o Maciço de Goiás pode representar terreno exótico. É limitado por importantes falhas de extensão regional. A noroeste o 
limite é com o Arco Magmático de Goiás, determinado pela Falha Rio dos Bois, empurrão em curva com direção inicialmente próxima de E-W e mesmo NW-SE e vergência para sul, passando gradativamente para direção NE-SW e vergência sudeste. O prolongamento nordeste do empurrão adquire as características de transcorrência destra de alto ângulo, que faz parte do sistema de transcorrências do Lineamento Transbrasiliano, mais além encoberto pela Bacia do Parnaíba. O limite oeste do Maciço de Goiás é marcado pela transcorrência sinistral N-S Moiporá-Novo Brasil, que o separa da porção meridional do Arco Magmático de Goiás. O limite sul é constituído pela sequência paleoproterozoica Serra Dourada empurrada sobre os terrenos granitogreenstone arqueanos. O empurrão inflete para norte, segmentado por vários traços de falhas transcorrentes E-W, separando os terrenos arqueanos de rochas de alto grau e unidades do Grupo Araxá. Via transição pouco entendida, o limite passa para a Falha Rio Maranhão, marcando a borda do Complexo Barro Alto. A falha verga para N-NE na inflexão do complexo, em regime de empurrão dominante, segmentado por transcorrências, sobrepondo os complexos Barro Alto, Niquelândia e Cana Brava a rochas da zona externa da faixa e seu embasamento. Em seu prolongamento NE a Falha Rio Maranhão se integra ao Lineamento Transbrasiliano, passando a transcorrência destra, adiante encoberta pela Bacia do Parnaíba.

Os dados mostram que o Maciço de Goiás é limitado por falhas em toda sua extensão e é constituído por unidades litoestratigráficas distintas em natureza, idade e evolução das rochas que o cercam. Em consequência, o Maciço de Goiás preenche as condições estipuladas pelo conceito de terrenos, podendo ser caracterizado como terreno acrescido à margem do paleocontinente São Francisco no contexto da evolução orogênica da Faixa Brasília e da Província Tocantins.

As evidências disponíveis sugerem que também o Arco Magmático de Goiás e o conjunto de rochas de alto grau metamórfico do Complexo Anápolis-Itauçu, limitados por extensas zonas de cisalhamento, podem ser classificados como terrenos. 


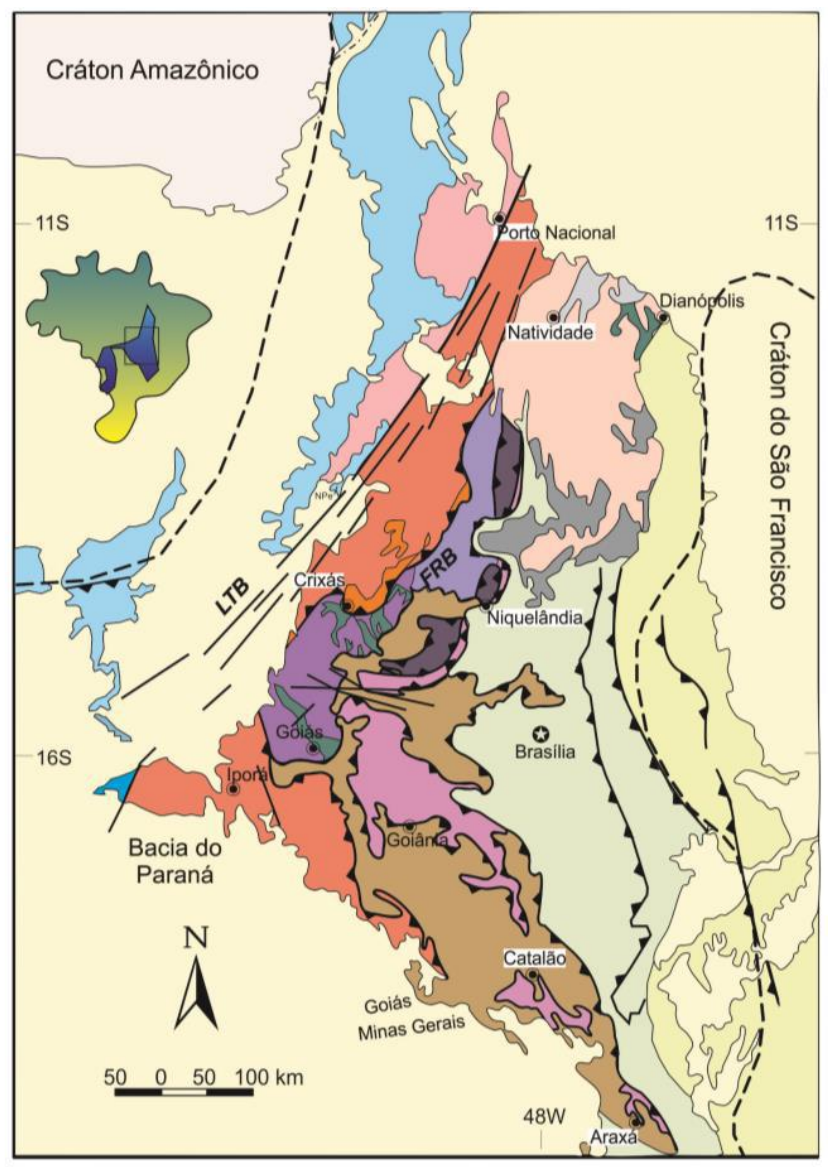

\section{LEGENDA}

Cobertura Fanerozoica

Faixas Paraguai e Araguaia

Sequências supracrustais

Granulito/ortognaisse (Alto do embasamento)

Faixa Brasília

Zona externa

Grupo Bambui (Bacia de Foreland)

Grupos Paranoá e Canastra (Margem Passiva)

Rifte Arai $\square$ Grupo Natividade

Greenstone belts / Ortognaisses (Alto do embasamento)

Zona Interna

Grupo Araxá / Mélange Ofiolitica (Sutura)

Complexo Anápolis-Itauçu:

Granulitos, ortognaisses e paragnaisses (Terreno Tectonoestratigráfico)

Arco Magmático de Goiás (Terreno tectonoestratigráfico)

Sequências Vulcano-sedimentares

Ortognaisses

Maciço de Goiás (Terreno exótico?)

Cobertura dobrada / Grupo Serra da Mesa

Compl. Máfico-ultramáficos

Sequências Vulcano-Sedimentares

Greenstone belts / Ortognaisses

Estruturas

1 Lineamento

Transbrasiliano

Contatos

Falhas ou Zonas de

Cisalalhamento de empurrão _-' Limites da Provincia

Figura 8.8 - Compartimentação tectonoestratigráfica da Província Tocantins, modificado de Fuck et al., 1994. LTB = Lineamento Transbrasiliano, FRB = Falha Rio dos Bois.

\subsubsection{Província Borborema (NE do Brasil)}

A Província Borborema pode ser definida como produto da colagem neoproterozoica de um complexo sistema orogênico, que tem continuidade em várias faixas orogênicas da África ocidental (Figura 8.9). As cinco subprovíncias nela identificadas possuem histórias evolutivas distintas, não sendo possível definir um modelo aceitável a luz da tectônica de placas que explique toda a diversidade tectonoestratigráfica nela inserida. Isso porque, além dos mecanismos associados à colisão brasiliana, extensas zonas de cisalhamento subparalelas ao limite orógeno-cráton produziram um notável processo de dispersão, que torna problemática qualquer correlação entre os cinturões metamórficos presentes nos diferentes domínios estruturais (aqui chamados de subprovíncias) que a compõem. 
As subprovíncias ao norte do Lineamento Patos possuem em comum a existência de um substrato paleoproterozoico ou arqueano-paleoproterozoico, mas o arco magmático Tamboril-Santa Quitéria e os domínios de alta/ultralta pressão de Forquilha, na subprovíncia Ceará Central, demonstram geração de crosta juvenil criogeniana e indicação de que essa porção da Província fez parte de um vasto oceano, que tem sido chamado de Goiás-Farusiano, numa reconstituição pré-deriva dos continentes africano e sulamericano (Cordani et al. 2013; Araújo et al. 2014). A amalgamação das duas subprovíncias é balizada pelo suturamento plutônico dos granitos Meruoca e Mucambo ao longo do Lineamento Transbrasiliano, entre 560 e 460 Ma. Sobre esse terreno composto implantou-se no final do Ediacarano e Cambriano (540-530 Ma) o rifte Jaibaras, por reativação desta importante sutura crustal, amarrando, por ligação de proveniência, a amalgamação dessas duas subprovíncias.

Entre as subprovíncias Ceará Central e Rio Grande do Norte, ocorre um terreno paleoproterozoico único na Província Borborema, o rifte estateriano Orós-Jaguaribe, que foi amalgamado aos domínios acima por soldagem metamórfica ao longo das zonas de cisalhamento Senador Pompeu e Portalegre. As subprovíncias Rio Grande do Norte e Transversal também foram soldadas metamorficamente através do Lineamento Patos, há 566 Ma. Os granitos peralcalinos de tipo Catingueira, embora de distribuição restrita, também amarram por suturamento plutônico a colagem dessas duas subprovíncias, em torno de 573 Ma. A Subprovíncia Transversal foi formada por dois episódios de colagem distintos e sucessivos: Cariris Velhos (995-920 Ma, só conhecido ao sul do Lineamento Patos) e Brasiliano (650-540 Ma), os quais geraram faixas metamórficas paralelas entre si (Alto Pajeú e Piancó-Alto Brígida). Nesse contexto, se insere o terreno paleoproterozoico, Alto Moxotó (TAM), um inlier contínuo, de grande espessura crustal, segundo confirmam recentes investigações geofísicas (Santos et al. 2014; Padilha et al. 2014; Lima et al., 2015). Apesar do intenso retrabalhamento brasiliano que afetou os blocos arqueano-paleoproterozoicos na Província, o TAM foi relativamente poupado desse processo, sugerindo uma clara aloctoneidade desse segmento crustal. A colagem do TAM ao terreno Rio Capibaribe ocorreu por soldagem metamórfica através da zona de cisalhamento Congo-Cruzeiro do Nordeste e suturamento plutônico dos granitoides peralcalinos da suíte Vila Moderna, que calibra a junção dos dois terrenos em 590 Ma. 


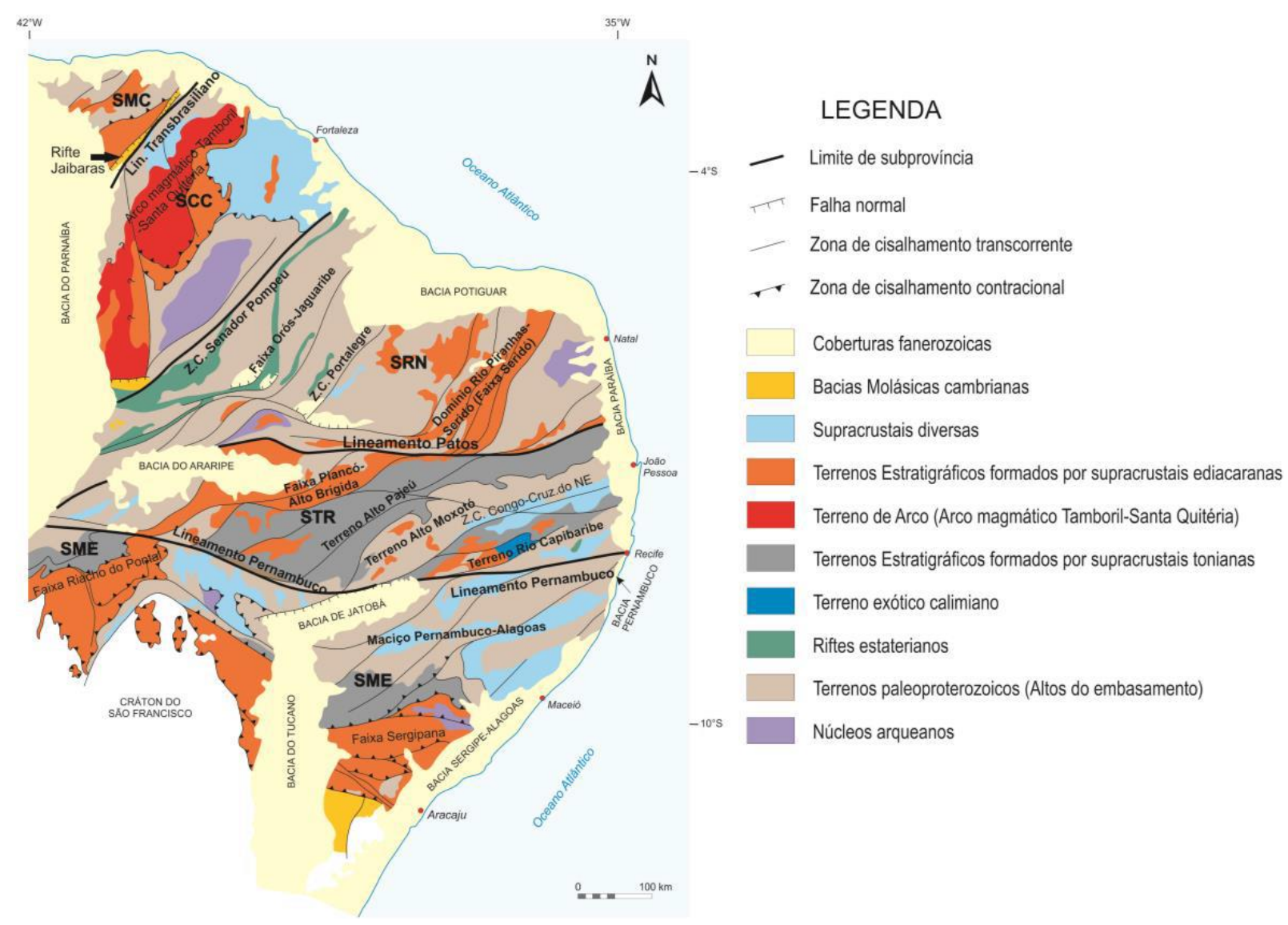

Figura 8.9 - Compartimentação tectonoestratigráfica da Província Borborema, modificado de Santos et al., 2014. SMC = Subprovíncia Médio Coreaú, SCC = Subprovíncia Ceará Central, SRN = Subprovíncia RIo Grande do Norte, STR = Subprovíncia Transversal, SME = Subprovíncia Meridional.

\subsection{Considerações finais}

(i) Análise de terrenos corresponde a uma técnica multidisciplinar aplicada ao estudo de cinturões orogênicos. Envolve técnicas de geologia convencionais (mapeamento geológico, análise estrutural, paleomagnetismo, geofísica etc.) e dados laboratoriais específicos (geoquímica de rocha, isótopos etc.);

(ii) O conceito de terrenos surgiu no início da década de 1980 com o objetivo de entender a origem de blocos considerados potencialmente alóctones ou suspeitos na cordilheira do oeste dos Estados Unidos, e tem sido aplicado em diversos cinturões orogênicos, tanto fanerozoicos quanto pré-cambrianos. Para aplicação do modelo de terrenos é importante que todos os elementos envolvidos no conceito sejam levados em consideração: "Pacote de rochas limitado por falhas ou zonas de cisalhamento importantes com estratigrafia 
e ambiente/história geológica distinta dos terrenos adjacentes”. Excluem-se discordâncias ou contatos geológicos que não correspondam a falhas importantes;

(iii) Terrenos ampresentam tamanhos variados, podendo ser classificados em estratigráficos, metamórficos e fragmentados, e serem descritos em função de características individuais referentes ao próprio terreno ou à margem continental. Alguns critérios são essenciais e podem auxiliar na identificação de terrenos distintos ou de limites que não são tão evidentes, tais como sequências de sobreposição, soldagem metamórfica, suturamento plutônico, ligação de proveniência, além da própria análise individual do terreno (geohistória);

(iv) Platôs oceânicos podem evoluir para terrenos, sendo a evolução destes o resultado de processos de crescimento crustal (por acreção e amalgamação) e destruição e modificação crustal, como rifteamento e dispersão. Amalgamação ocorre quando dois terrenos colidem anteriormente à acreção de material à margem continental. Dispersão representa um processo importante, pois promove o deslocamento lateral dos terrenos;

(v) O modelo de colagem de terrenos tem sido reconhecido em algumas províncias estruturais neoproterozoicas brasileiras, tais como as províncias Mantiqueira, Rondoniana-San Ignácio e Sunsás. No presente trabalho são apresentados nas províncias Tocantins e Borborema elementos tectônicos sugestivos da formação e acreção de terrenos, sendo essas um bom laboratório para o teste e aplicação do modelo em cinturões orogênicos pré-cambrianos.

\subsection{Agradecimentos}

Este trabalho é parte integrante da pesquisa de doutorado do primeiro autor na Universidade de Brasília. Os autores expressam sinceros agradecimentos ao Prof. Miguel Tupinambá da Universidade Estadual do Rio de Janeiro e a um revisor anônimo, pela paciente leitura e precisas sugestões, as quais melhoraram substancialmente o manuscrito original. Adicionalmente, agradecemos aos editores da revista Geonomos pela atenção, paciência e auxílio em todas as etapas da publicação do artigo. 


\subsection{Referências}

Adams, C.J., Campbell H.J., Graham I.J., Mortimer N. 1998. Torlesse, Waipapa and Caples suspect terranes of New Zealand: Integrated studies of their geological history in relation to neighbouring terranes. Episodes 21, 235-240.

Almeida, F.F.M., Hasui, Y., Brito Neves, B.B., Fuck, R.A. 1981. Brazilian structural provinces: An introduction. Earth Science Reviews 18,1-29.

Ben-Avraham, Z., Nur, A., Jones, D., Cox, A., 1981. Continental accretion: from oceanic plateaus to allochtonous terranes. Science $213,47-54$.

Bermanek, L.P., van Staal, C.R., McCelland, W.C., Israel, S., Mihalynuk, C.G. 2012. Detrital zircon Hf isotopic compositions indicate a northern Caledonian connection for the Alexander Terrane. Litosphere 5, 163-168.

Black R., Liégois, J.P., Latouche L., Caby R., Bertrand J.M. 1994. Pan-African displaced terranes in the Tuareg Shield (Central Sahara). Geology 22, 641-644.

Bolhar, R., Ring, U. 2001. Deformation history of the Yolla Bolly terrane at Leech Lake Mountain, Eastern belt, Franciscan subduction complex, California Coast Ranges. GSA Bulletin 113, 181-195.

Brito Neves, B.B., Santos, E.J., Schmus, W.R.V. 2000. Tectonic History of the Borborema Province. In: Umberto Cordani, Edson José Milani, Antonio Thomaz Filho, Diogenes de Almeida Campos. (Org). Tectonic Evolution of South America. v 1, pp. 151-182.

Brito Neves (2011). Glossário de Geotectônica. Oficina de Textos, 256 pp.

Butler, R. 1998. Palaeomagnetism: Magnetic domains to geological terranes. Blackwell Scientific Publications, Oxford, 319 pp.

Caxito, F., Uhlein, A., Stevenson, R., Uhlein, G.J. 2014. Neoproterozoic oceanic crust remmants in northeast Brazil. Geology 42, 387-390.

Coleman, R.G., Lee, E.D., Beatty, L.B., Brannock, W.W. 1965. Eclogites and eclogites: their differences and similarities. Geological Society of America Bulletin 76, 483-508. 
Colpron, M., Nelson, J.L., Murphy, D.C. 2007. Northern Cordilleran terranes and their interactions trough time. GSA Today 17, 4-10.

Coney, P.J., Jones, D.L., Monger, J.W.H. 1980. Cordilleran suspect terranes. Nature 288, 329-333.

Cox, G.M., Lewis, C.J., Cox, A.S., Hlaverson, G.O., Jourdan, F., Foden, J., Netle, D., Kattan, F. 2012. Ediacaran terrane accretion within the Arabian-Nubian Shield. Gondwana Research. 21, 341-352.

Dantas, E.L., Hackspacher, P.C., Fetter, A.H., Sato, K., Pimentel, M.M., Godoy, A.. 2000. Nd isotope systematics related to proterozoic evolution of the Ribeira Belt in the state of São Paulo, SE Brazil. Revista Brasileira de Geociências 30, 140-143.

Engebretson, D.C., Kelley, K.P., Cashman, H.P., Richards, M.A. 1992. 180 million years of subduction. GSA Today 2, 93-100.

England, T.D.J., Hiscott, R.N. 1992. Lithostratigraphy and deep-water setting of the upper Nanaimo Group (Upper Cretaceous), outer Gulf Islands of southwestern British Columbia. Canadian Journal of Earth Sciences 29, 574-595.

Frey, F.A., Coffin, M.F., Wallace, P.J., Weis, D., Zhao, X., et al. 2000. Origin and evolution of a submarine large igneous province: the Kerguelen Plateau and Broken Ridge, southern Indian Ocean. Earth Planet Science Letters 176, 73-89.

Fuck, R.A., Pimentel, M.M., D’el Rey, J.H. 1994. Compartimentação tectônica na porção oriental da Província Tocantins. In: 38 Congresso Brasileiro de Geologia, v. 1. p. 215-216.

Fuck, R.A., Dantas, E.L., Pimentel, M.M., Botelho, N.F., Armstrong, R., Laux, J.H., Junges, S.L., Soares, E.P., Praxedes, I.F. 2014. Paleoproterozoic crust-formation and reworking events in the Tocantins Province, Central Brazil: A contribution for Atlantica supercontinent reconstruction. Precambrian Research 244, 53-74.

Gardner, M.C., Bergman, S.C., Cushing, G.W., MacKevett, E.M.J., Plafker, G., Campbell, R.B., Dodds, C.J., McClelland, W.C., Mueller, P.A., 1988, Pennsylvanian pluton stitching of Wrangellia and the Alexander terrane, Wrangell Mountains, Alaska. Geology 16, 967-971. 
Grobys, J.W.G., Gohl, K., Uenzelmann-Neben, G., Davy, B.W., Barker, D.H.N. 2009. Extensional and magmatic nature of the Campbell Plateau and Great South Basin from deep crustal studies. Tectonophysics 472, 213-225.

Grove, M., Gehrels, G.E., Cotkin, S., Wright, .E., Zoug, H. 2008. Non-Laurentian cratonal provenance of Late Ordovician blueschists and a link to the Alexander terrane. Geological Society of America Special Paper 438, 223-250.

Guynn, J.H., Kapp, P., Pulle, A., Gehrles, G., Ding, L. 2006. Tibetan basement rocks near Amdo reveal "missing" Mesozoic tectonism along the Bangong Suture, Central Tibet. Geology 34, 505-508.

Haggart, J.W., Enkin, R.J., Monger, W.H. 2006. Strengths and limitations of paleogeographic methods in assessing large-scale displacements within the North American Cordillera. In Paleogeography of the North American Cordillera: Evidence for and against Large-Scale Displascements. Geoological Society of Canada Special Paper 7, 1-11.

Heilbron, M., Valeriano, C.M., Tassinari, C.C.G., Almeida, J.C.H., Tupinambá, M., Siga Jr., O., Trouw, R.A.J., 2008. Correlation of Neoproterozoic terranes between the Ribeira Belt, SE Brazil and its African counterpart: comparative tectonic evolution and open questions. In: Pankhurst, R.J., Trouw, R.A.J., Brito-Neves, B.B., de Wit, M. (Eds.), West Gondwana pre-Cenozoic Correlations Across the South Atlantic Region. Geological Society of London, Special Publication 294, pp. 211-232.

Hillhouse, J.W., Gromme, C.S., Vallier, T.L. 1982. Paleomagnetism and Mesozoic tectonics of the Seven Devils volcanic arc in northeastern Oregon: Journal of Geophysical Research 87, 3777-3794.

Howell, D.G. 1989. Tectonics of Suspect Terranes. Mountain Building and Continental Growth. Chapman \& Hall, 233 pp.

Howell, D.G. 1995. Principles of Terrane analysis. Chapman \& Hall, 245 pp.

Irving, E., Yole, R.W. 1972. Paleomagnetism and the kinematic history of mafic and ultramafic rocks in fould mountain belts. In Irving, E., Editor. The ancient oceanic lithosphere: Earh Physics Branch, Ottawa 42, 87-95. 
Irwin, W.P. 1960. Geological reconnaissance of the northern Coast Ranges and Klamath Mountains, California. Div. Mines and Geology Bulletin, v. 179 80p.

Irwin, W.P. Terranes and the western Paleozoic and Triassic belt in the southern Klamath Mountains, California. Geological Survey Research 800, 103-111.

Jayko, A.S., Blake Jr, M.C. 1989. Deformation of the Eastern Franciscan Belt, northern California. Journal of Structural Geology 11, 375-390.

Jones, D.L., Silberling, N.J., Hillhouse, J. 1977. Wranggellia a displaced terrane in northwestern North America. Canadian Journal of Earth Sciences 14, 2565-2577.

Jones, D.L., Howell, D.G., Coney, P.J., Monger, J.W.H. 1983. Recognition character and analysis of tectono-estratigraphic terranes in western Nortth America. in Hashimoto, M., Yueda, S., eds. Accretion Tectonics in the Circum Pacific Region: Terra, v, 1 p. 21-35.

Kimbrough, D.J., Tulloch, A.J., Coombs, D.S., Landis, C.A., Johnston, M.R., Mattinson, J.L. 1994. Uranium-lead zircon ages from the Median Tectonic Zone, New Zealand. Journal of Geology and Geophisics 37, 393-419.

Kinny, P.D., Mass, R. 2003. Lu-Hf and Sm-Nd isotope systems in zircon. Reviwes in mineralogy and geochemistry 53, 327-341.

Lima, M.V.A.G., Barrocal, J., Soares, J.E.P., Fuck, R.A. 2015. Deep seismic refraction experiment in northeast Brazil: New constraints for Borborema province evolution. Journal of South American Earth Sciences 58, 335-349.

MacKinnon, T.C. 1983. Origin of the Torlesse terrane and coeval rocks, South Island, New Zealand. Geological Society of American Bulletin 94, 967-985.

Monger, J.W.H., Ross, C.A. 1971. Distribution of fusulinaceans in the western Canadian Cordillera. Canadian Journal of Earth Sciences 8, 259-278.

Monger, J.W.H., Price, R.A. Tempelman-Kluit, D.J. 1982. Tectonic accretion and the origin of two metamorphic and plutonic melts in the Canadian Cordillera. Geology 10, 70-75. 
Monger, J.W.H., Nokleberg., W.J. 1996. Evolution of the northern North American Cordillera: Generation, fragmentation, displacement and accretion of successive North American plate-margin arcs. in Coyner, A.R., and Fahey, P.L., eds., Geology and Ore Deposits of the American Cordillera: Geological Society of Nevada Symposium, Proceedings, v. 3, p. 1133-1152.

Monger, J.W.H., Price, R.A. 2002. The Canadian Cordillera: Geology and tectonic evolution. Canadian Society of Exploration Geophysicists Recorder 27, 17-36.

Mortimer, N. 2004. New Zealand’s geological foundations. Gondwana Research 7, 261272.

Mustard, P.S., Rouse, G.E. 1994. Stratigraphy and evolution of Tertiari Georgia Basin and subjacent Upper Cretaceous sedimentary rocks, southwestern Britsh Columbia and northwestern Washington State. In Geological hazards of the Vancounver region, southwestern British Columbia. Geological Survey of Canada, v. 481, p. 97-170.

Mustard, P.S., Mahoney, J.B., Fanning, C.M., Friedman, R.N., McNicoll, V.J. 2000. Naraimo Group, southwest Brittish Columbia: a Late Cretaceous basin with a continuos northern provenance signature. In Cordilleran Section Annual Meeting. Geological Society of America, v. 32, p. 57.

Mustoe, G.E., Gannaway, W.L., 1997. Paleogeography and Paleontology of the Early Tertiary Chuckanut Formation, Northwest Washington. Washington Geology 2, 3-18.

Neves, S.P. 2015. Constraints from zircon geochronology on the tectonic evolution of the Borborema Province (NE Brazil): Widespread intracontinental Neoproterozoic reworking of a Paleoproterozoic Accretionary orogen. Journal of South American Earth $158,150-164$.

Nokleberg, W.J., Parfenov, L.M., Monger, J.W.H., Norton, I.O., Khanchuk, A.I., Stone, D.B., Scotese, C.R., Scholl, D.W., and Fujita, K., 2000, Phanerozoic tectonic evolution of the circum-North Pacific: U.S. Geological Survey Professional Paper., 1626:122 p.

Nur, A., Ben-Avraham, Z., 1982. Oceanic plateaus, the fragments of continents, and mountain building. Journal of Geophysical Research 87, 3644-3661. 
Packer, D.R., Stone, D.B. 1972. An Alaskan Jurassic paleomagnetic pole and the Alaskan orocline. Nature 237, 25-26.

Padilha, A.L., Vitorello, I., Pádua, M.B., Bologna, M.S. 2014. Electromagnetic constraints for subduction zones beneath the northwest Borborema province: Evidence for Neoproterozoic island arc-continent collision in northeast Brazil, Geology. 42, 9194.

Rizzotto, G.J., Quadros, M.L., 2005. Geologia do Sudoeste do Cráton Amazônico. In: Horbe, Adriana; Souza, Valmir da Silva (Orgs.). Contribuições à Geologia da Amazônia. 69-84.

Rodrigues, S.W.O., Brito Neves, B.B. 2008. Padrões isotópicos Sm-Nd no limite entre os Terrenos Alto Pajeú e Alto Moxotó (PB). Revista Brasileira de Geociências 38, 211 227.

Samson, S.D., Hibbard, J.P., Wortman, G.L. 1995. Nd isotopic evidence for juvenile crust in the Carolina terrane, southern Appalachians: Contributions to Mineralogy and Petrology 121, 171-184.

Santos, A.C.L., Padilha, A.L., Fuck, R.A., Pires, A.C.B., Vitorello, I., Pádua, M.B. 2014. Deep structure of a stretched lithosphere: Magnetotelluric imagin of the southeastern Borborema Province, NE Brazil. Tecthonophysics 610, 39-50.

Santos, E.J. 1996. Ensaio preliminar sobre terrenos e tectônica acrescionária na Província Borborema. In $39^{\circ}$ Congresso Brasileiro de Geologia, v 1, pp. 47-50.

Santos, E.J. ; Souza Neto, J.A. ; Silva, M.R.R. ; Beurlen, H. ; Cavalcanti, J.A.D. ; Silva, M.G. ; Dias, V.M. ; Costa, A.F. ; Santos, L.C.M.L. ; Santos, R.B. Metalogênese das porções norte e central da Província Borborema. In: Maria da Glória da Silva; Manoel Barreto da Rocha Neto; Hardy Jost; Raul Minas Kuyumjian. (Org.). 2014. v. 1. p. 343388.

Scandolara, J., Amorim, J.L., Rizzoto, G.J., Quadros, M.L.E.S., 2001. Evolução geológica do segmento sudoeste do Cráton Amazônico Estado de Rondônia e adjacências.. In: Nélson Reis; Marcos Monteiro. (Org.). Contribuições à Geologia da Amazônia. Manaus: SBG/Núcleo Norte, v. 2, p. 251-340. 
Schermer, E., Howell, D.G., Jones, D.L. 1984. The origin of allochtonous terranes: perspectives on the growth and shaping of continents. Annual Reviews of Earth and Planetary Sciences 12, 107-131.

Schubert, G., Sandwell, D. 1989. Crustal volume of the continents and of oceanic and continental submarine plateaus. Earth and Planetary Letters 92, 234-246.

Stoeser, D.B., Frost, C.D. 2006. Nd, Pb, Sr and O isotopic characterization of Saudi Arabian Shield Terranes. Chemical Geology 226, 163-188.

Van Schmus, W.R., Oliveira, E.P., Silva Filho, A.F., Toteu, F., Penaye, J., Guimarães, I.P. 2008. Proterozoic links between the Borborema Province, NE Brazil, and the Central African Fold Belts. Geological Society of London, Special Publications 294, 66-69.

Vogt, K., Gerya, T.V. 2012. From oceanic plateaus to allochtonous terranes: Numerical modelling. Gondwana Research 25, 494-508.

Wortman, G., Samson, S.D., Hibbard, J.P. 1996. Discrimination of the Milton and Carolina slate belts, southern Appalachians: A Nd isotopic approach. Journal of Geology 104, 249-247.

Zegers, E.T., van Keken, P.E. 2001. Middle Archean continent formation by crustal delamination. Geology 29, 1038-1086.

Zelek, M., Dickin, A. 2013. Nd isotope mapping of crustal terranes in the Parent-Clova Area, Quebec: Implications for the evolution of Laurentian Margin in the Centra Grenville Province. Geosciences 3, 448-465. 